$$
\text { UNIVERSIDADE DE SÃO PAULO }
$$

FACULDADE DE FILOSOFIA, LETRAS E CIÊNCIAS HUMANAS DEPARTAMENTO DE HISTÓRIA ECONÔMICA PROGRAMA DE PÓS-GRADUAÇÃO EM HISTÓRIA ECONÔMICA

\title{
Política e Seca no Ceará Um projeto de desenvolvimento para o Norte (1869-1905)
}




$$
\text { UNIVERSIDADE DE SÃO PAULO }
$$

FACULDADE DE FILOSOFIA, LETRAS E CIÊNCIAS HUMANAS

DEPARTAMENTO DE HISTÓRIA ECONÔMICA

PROGRAMA DE PÓS-GRADUAÇÃO EM HISTÓRIA ECONÔMICA

José Weyne de Freitas Sousa

\section{Política e Seca no Ceará Um projeto de desenvolvimento para o Norte (1869-1905)}

Tese apresentada ao Curso de Doutorado em História Econômica do Departamento de História da Faculdade de Filosofia, Letras e Ciências Humanas, como requisito parcial à obtenção do título de doutor.

Orientadora: Profa. Dra. Eni de Mesquita Samara.

São Paulo, 2009 
Para Maria Salete e Marinella B. Rossetti 


\section{Resumo}

Neste trabalho historiográfico procuramos mostrar que de 1869 a 1905, houve a implantação de um projeto de desenvolvimento econômico para o Ceará que se baseava no emprego de trabalhadores desvalidos durante as secas que atingiram a região Norte (atual Nordeste) quando havia uma escassez de água, alimentos e forragem para os gados. Nesse período, os socorros públicos foram implantados à luz do projeto Pompeu Sinimbú, que levou as famílias pobres sertanejas a migrarem em direção às cidades litorâneas onde o governo acenava com os socorros públicos. Por trás da idealização do projeto Pompeu Sinimbú havia o problema das disputas por melhoramentos materiais entre o Norte e o Sul do Brasil.

Mas a consecução desse projeto atingiu diretamente a população pobre sertaneja que ao invés de receber o socorro no próprio domicílio ou ser alvo de políticas públicas de prevenção aos efeitos das secas, foi utilizada como mão de obra abundante e barata, cujo sofrimento diante da seca servia para que as elites conseguissem o envio de recursos à província. Denominamos esse projeto de Pompeu Sinimbú, porque ele foi concebido inicialmente pelo senador Pompeu e tornado oficial pelo visconde de Sinimbú. Esse projeto preconizava a idéia de utilizar a mão de obra disponível durante as secas para a realização de obras públicas, pautando nesse mecanismo o progresso da província. Porém, paralelamente a execução dessa proposta houve uma outra propugnada pelo barão de Capanema e pela Comissão Científica de Exploração que não considerava a seca um óbice ao desenvolvimento da região, mas o atraso da atividade agrícola e a falta de medidas de prevenção aos efeitos das estiagens.

Palavras-chaves: seca, política, progresso, agricultura e população. 


\section{Abstract}

In this work we tried to show that from 1869 to 1905 , there was the implantation of a project of economical development for Ceará that based on the destitute workers' job during the droughts that reached the North area (current Northeast) when there were a shortage of water, foods and forage for the cattle. In that period, the public helps were implanted to the light of the project Pompeu Sinimbú, that took the country poor families migrate her towards the coastal cities where the government waived with the public helps. Behind the idealization of the project Pompeu Sinimbú there was the problem of the disputes for material improvements between the North and the South of Brazil.

But the attainment of that project reached the country poor population directly that instead of receiving the help in the own home or white being of public politics of prevention to the effects of the droughts, it was used as hand of abundant and cheap work, whose suffering before the drought served so that the elites got the sending of resources to the province. We denominated that project of Pompeu Sinimbú, because he was conceived initially by senator Pompeu and tornado official by the viscount of Sinimbú. That project extolled the idea of using the hand of available work during the droughts for the accomplishment of public works, ruling in that mechanism the progress of the province. However, parallel the execution of that proposal had another one proposed by the baron of Capanema and for the Scientific Commission of Exploration that didn't consider the drought an obstacle to the development of the area, but the delay of the agricultural activity and the lack of prevention measures to the effects of the droughts.

Key-word: dries, politics, progress, agriculture and population. 


\section{Sumário}

Agradecimentos

Lista de Abreviaturas

Listas de Mapas e Ilustrações

Resumo/abstract

Introdução - I -XVIII

PARTE I

DA VIOLÊNCIA À SECA

CAPÍTULO 1 - VIOLÊNCIA NO SERTÃO: PROBLEMA POLÍTICO E ECONÔMICO (1840-1876).

1.1. -PENAS DE MORTE NO CEARÁ.............................................................................................01

1.2.-O MINISTÉRIO EUSÉBIO ENVIA SILVEIRA DA MOTTA............................................19

CAPÍTULO 2 - A SECA DE 1877-79 E A LEI FORÇADA DO SENADOR POMPEU

1.3.-A SECA SOBREPUJA OS DEMAIS ACONTECIMENTOS............................................... 41

1.4.- RODOLFO TEÓFILO E AS GRANDES SECAS...................................................52

PARTE II

UM PROJETO DE DESENVOLVIMENTO PARA O NORTE

CAPÍTILO 3 - DA AGROEXPORTAÇÃO À ATIVIDADE MANUFATUREIRA: DISPARIDADES ECONÔMICAS

3.1.-AGRICULTURA, COMÉRCIO E MANUFATURA..................................................................80

3.2. OS GARGALOS DA AGROEXPORTAÇÃO E AS DISPARIDADES.................................95

CAPÍTULO 4 - PROJETO POMPEU SINIMBÚ: DIRETRIZES PARA O PROGRESSO DO NORTE.

4.1. SOCORROS PÚBLICOS INDIRETOS.........................................................111

4.2. PSEC - Planos de Socorros Estáveis e CoMpletos............................138

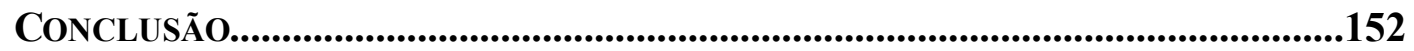

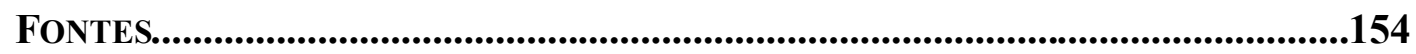

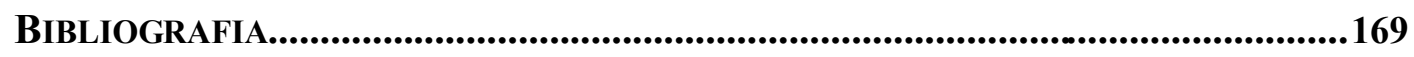




\section{Agradecimentos}

A escrita desta tese se tornou possível à medida que recebi apoios e incentivos variados. Ao longo do doutorado o contato com professores e com o debate presente dentro da História Econômica me levou a refazer abordagem da pesquisa. Com isso, agradeço ao professor José Flávio Mota pelas análises insistentes de tabelas e gráficos que me ajudaram a utilizar a estatística não como um fim, mas como um meio para se pensar questões sociais, políticas $e$ econômicas. Devo ao professor Horácio Gutierrez o alerta para o fato de que minha pesquisa não tratava de família, mas de população.

Ao professor Antonio Carlos de Almeida Bacelar sou grato por ele ter me ajudado a compreender os modos possíveis de se escrever História da Família na Europa e no Brasil. À minha orientadora Eni de Mesquita Samara rendo gratidão pela confiança em mim depositada e pela parceria na escrita de alguns artigos que muito me honraram dada a sua credibilidade e reconhecimento internacional nos estudos de população e família. Aos companheiros do Cedhal, André e Leandro, sou grato pelos momentos de debate, reflexão e diversão comigo candidamente compartilhados. Devo às secretárias Vilma, Iara e Cida a presteza com que me mantiveram sempre informado acerca dos prazos, noticias e eventos os quais procurei cumprir fielmente.

A professora Esmeralda Bolsonaro Blanco de Moura agradeço por compartilhar algumas opiniões acerca da História da Criança. Ao professor Manoel Fernandes eu devo os apontamentos bibliográficos sobre o Senador Pompeu que me ajudaram a compreender melhor o papel desse personagem na História do Ceará. Ao amigo Felipe Ronner agradeço por compartilhar comigo seus avanços nos estudos semióticos e por me ouvir falar de seca e economia. $A$ Marinella Binda Rossetti sou grato pelas longas horas em que ela me ouviu falar de um assunto tão estranho a realidade paulistana: a seca. Já aos seus pais Vitaliano e Maria agradeço pelos momentos de convívio familiar que me foram dispensados.

Ao CNPq agradeço a bolsa que tornou possível o desenvolvimento dessa pesquisa. 


\section{Abreviaturas}

APEC - Arquivo Público do Estado do Ceará.

BPGMP - Biblioteca Pública Governador Menezes Pimentel.

BNRJ - Biblioteca Nacional do Rio de Janeiro.

CEDHAL - Centro de Demografia Histórica da América Latina.

IC - Instituto do Ceará

IHGB - Instituto Histórico e Geográfico do Ceará 


\section{Tabelas e gráficos}

Tabela 1: Reclassificação das grandes secas segundo Raja Gabaglia, p.56.

Tabela 2: Relação dos verões mais secos do Ceará (1855-1898), p.60

Tabela 3: Orçamento da despesa provincial do Ceará para o ano de 1877, p. 77.

Tabela 4: Exportação efetuada no primeiro trimestre de 1865, p.91.

Tabela 5: Dados de alguns municípios do Ceará relativos ao ano de 1896, p.94

Tabela 6: Custo com transporte de gêneros no Ceará (1872), p.95.

Tabela 7: Folha dos empregados no serviço de elevação do aterro da Lagoa da Pajussara (1889), p.112.

Tabela 8: As secas que atingiram algumas províncias do Norte no século XX, p.133.

Gráfico 1: Comparação entre o número de crimes cometidos e o número de criminosos capturados (1852-1876), p.40.

Gráfico 2: Evolução da matrícula escolar no Ceará (1845-1881), p.42.

Gráfico 3: Comparação entre o número de crimes cometidos e número de criminosos capturados, p.44.

Gráfico 4: Mortalidade da população de Fortaleza durante a enchente de 1889, p.46.

Gráfico 5: Índice pluviométrico relativo ao Ceará nos meses de janeiro a meio, ao longo de 10 qüinqüênios (1849- 1898), p.59.

Gráfico 6: Índice pluviométrico relativo as principais secas do século XIX, p.60.

Gráfico 7: Quantidade de anos de secas em comparação com os anos de invernos regulares no Ceará (1710-1900), p.61.

Gráfico 8: Exportação da borracha da mangabeira pelo porto de Fortaleza (18661876), p.62.

Gráfico 9: Produção agrícola cearense (1845-1879), p.63.

Gráfico 10: Produção açucareira e cafeeira cearense durante a seca de 1877-79, p.64.

Gráfico 11: Exportação de algodão cearesense, p.69.

Gráfico 12: Produção pastoril cearense, p, 70. 
Gráfico 13: Indústria criadora ou pastoril no Ceará (1845-1876), p.71

Gráfico 14: Importações e exportações saídas dos portos cearenses (1847-1876), p.72.

Gráfico 15: Análise comparativa da importação-exportação no Ceará durante a seca de 1877-79, 73

Gráfico 16: Receita e despesa, 1845-1879, p.74.

Gráfico 17: Receita e despesa, 1877, 1878, 1879, p.75.

Gráfico 18: Evolução da população do Ceará (1775-1872), p.78.

Gráfico 19: quantias despendidas com obras públicas entre os anos de 1836 a 1866, p.83.

Gráfico 20: Exportação de algodão e couro por KG, p.91.

Gráfico 21: Exportação de B9orracha, p.92.

Gráfico 22: Quantidade de KG de café e açúcar exportado, p.92.

Gráfico 23: Relação de dias chovidos/ milímetros, p. 98. 


\section{Introdução}

No final de 1940 a ONU criou um órgão denominado de Cepal (Comissão Econômica Para a América Latina), formado por um grupo de economistas e outros cientistas sociais reunidos em Santiago do Chile. Os autores cepalinos além de terem estabelecido um "manifesto" pelo desenvolvimento latino americano, elaboraram uma estrutura conceitual própria que deu suporte e legitimidade as "propostas de política econômica" oriundas daquele órgão. ${ }^{1}$ Celso Furtado, principal autor cepalino, não apenas aplicou as teses da comissão para explicar o subdesenvolvimento do Brasil e do Nordeste, como fundou um órgão, a SUDENE, para torná-las exeqüíveis.

Segundo Clélio C. Diniz a primeira interpretação teórica sobre as desigualdades regionais no Brasil, e possivelmente na América Latina, foi “elaborada no final da década de 1950, através do famoso relatório do GTDN, escrito por Celso Furtado, em 1958”. ${ }^{2}$ Furtado mostrou empiricamente que a renda per capta da região Nordeste era inferior a um terço daquela da região Centro-Sul do Brasil. Ele atribuiu ao processo de colonização a dicotomia entre o Norte e o Sul. Em primeiro lugar devido ao fato da economia agroexportadora ter sido baseada no trabalho escravo e em segundo lugar, esta ao demandar animais de carga e proteína animal, criou sua própria periferia, no interior a ela subordinada e dependente. E por último, a organização das fazendas do semi-árido assentadas no controle da terra e numa população sertaneja sem terra e sem salário, que

\footnotetext{
${ }^{1}$ COLISTETE, Renato Perim. O Desenvolvimento Cepalino: problemas teóricos e influências no Brasil. Tamás, COELHO, Francisco da Silva. (orgs.) Ensaio de História do Pensamento Econômico no Brasil Contemporâneo. São Paulo: Atlas, 2007, p.27.

2 DINIZ, Clélio Campolina. A questão Regional e as Políticas Governamentais no Brasil. In: SZMRECSÁNYI, Tamás, COELHO, Francisco da Silva. (orgs.) Ensaio de História do Pensamento Econômico no Brasil Contemporâneo. São Paulo: Atlas, 2007, p. 81 e 82.
} 
trabalhava sob o regime da meação. ${ }^{3}$ Essas três características teriam impedido o processo de modernização da agricultura na região Nordeste.

Não obstante, Celso Furtado e o GTDN (Grupo de Trabalho para o Desenvolvimento do Nordeste) partiram da perspectiva de que o caminho natural para o desenvolvimento econômico seria a existência de recursos naturais em abundância (solo e água) e mão de obra. Isso geraria a exportação de produtos primários, o que elevaria o nível da renda. $\mathrm{O}$ aumento da renda provocaria uma procura por bens e serviços e isso consubstanciaria um mercado interno. Este por sua vez levaria a diversificação da estrutura produtiva, ou seja, a industrialização.

Contudo, o GTDN considerou que esse caminho natural para o desenvolvimento do Nordeste foi fechado porque havia uma pobreza relativa dos recursos naturais que se agravava devido ao crescimento populacional. A conjugação desses fatores impossibilitava a expansão da agroexportação, com isso predominava o setor de subsistência. Como esse setor não gerava renda inexistia um mercado interno, o que acarretava na não diversificação da estrutura produtiva (industrialização). Sem industrialização, força motriz do desenvolvimento econômico e o aumento crescente da população havia um agravamento da pobreza.

Não obstante, as secas atingiam exatamente a produção de alimentos, levando a população camponesa a um contexto de miséria e fome. Por ouro lado, segundo o GTDN as medidas contra as secas não permitiam mudar o quadro estrutural porque a construção de açudes não se traduzia na criação de capacidade produtiva, pois esses não eram usados nem para a produção de energia, nem para a irrigação. Com isso, Celso Furtado explicou o subdesenvolvimento do Norte a partir da tese cepalina do desenvolvimento desigual e dependente que ele usou para analisar o período colonial, caracterizando-o como marcado pela plantação de

${ }^{3}$ DINIZ, Clélio Campolina. Op. cit., p.82. 
produtos tropicais e afirmando que a Colônia estava integrada nas economias européias, das quais dependia, não constituindo, portanto, um sistema autônomo, "sendo simples prolongamento de outros maiores". ${ }^{4}$ Nesses termos, a economia do Norte também seria um apêndice da economia do Sul.

Contrapomos a essa perspectiva externa o processo histórico de evolução política e econômica da região. O projeto Pompeu Sinimbú de desenvolvimento para o Norte se baseava na idéia da seca como óbice ao progresso material da região. Porém, essa idéia não surgiu com o GTDN, pois em 1877 ela se estabeleceu politicamente com a criação das comissões de socorros públicos e a associação entre socorros públicos diretos (distribuição de alimentos) e socorros públicos indiretos (emprego de trabalhadores) proposta pelo senador Pompeu em 1869.

Voltamo-nos ao século XIX porque nesse tempo houve a contraposição de duas propostas fundamentais para o progresso material da região Norte. A primeira decorreu da expedição realizada no Ceará pela Comissão Científica de Exploração (1859-1861), ${ }^{5}$ e a segunda surgiu do esforço político do senador Pompeu a partir de 1869 de aproveitar a mão-de-obra desvalida disponível durante as secas para a realização dos melhoramento s materiais da província, utilizando-a na construção de obras públicas. Os dois projetos partiram de premissas opostas: para os cientistas da Comissão Científica de Exploração a seca não era um óbice ao progresso material da região, mas o atraso da atividade agrícola.

Já o senador Pompeu enfatizou justamente o contrário, condicionando o desenvolvimento material da região a uma política de combate às secas, ou

\footnotetext{
${ }^{4}$ FURTADO, Celso. Formação econômica do Brasil. São Paulo: Companhia Editora Nacional, 1967, p.95.

5 BRAGA, Renato. História da Comissão Científica de Exploração. Fortaleza: Imprensa Universitária do Ceará, 1962, p.40.
} 
melhor, de aproveitamento destas para soerguer o progresso da província.

No entanto, a historiografia que aborda o problema do subdesenvolvimento no Nordeste demarca a preocupação com a implantação de uma política de desenvolvimento para a região a partir da publicação do documento "Uma política de Desenvolvimento para o Nordeste" escrito por Celso Furtado quando este fazia parte do GTDN em $1958 .{ }^{6}$ Contudo, no século XIX foi implantado um projeto que denominamos de Pompeu Sinimbú (1869-1905), cujo objetivo era alavancar o progresso material do Ceará, mas terminou influenciando a política de desenvolvimento na região Norte. Celso Furtado e o GTDN utilizaram como parâmetro para traçar uma política de desenvolvimento para a região Nordeste na década de 60 o paradigma cepalino do “desenvolvimento desigual". 7

No entanto, a proposta do GTDN não representou uma ruptura porque o senador Pompeu partiu em 1869 de uma noção semelhante a da CEPAL. De acordo com ele o progresso material do Norte foi desigual em relação ao Sul. E tanto o senador quanto a SUDENE de Celso Furtado defenderam a necessidade de um papel ativo do estado e da variável investimento público como meio para se alterar essa relação econômica desigual. João Manuel Cardoso de Mello na sua revisão crítica ao paradigma cepalino observou que nem todos os investimentos poderiam ser induzidos pela procura preexistente, e como era preciso que alguns antecipassem a demanda, em especial os investimentos de base, isso exigia "a presença ativa do Estado (uma vez que não se crê muito nos "empresários

\footnotetext{
${ }^{6}$ DINIZ, Clélio Campolina. "A questão regional e as políticas governamentais no Brasil”. In: SZMRECSÁNYI, Tamás, COELHO, Francisco da Silva (org.). Ensaios de História do Pensamento Econômico no Brasil Contemporâneo. São Paulo: Atlas, 2007, p.81.

7 MELlO, João Manuel Cardoso de. O Capitalismo Tardio: contribuição à revisão crítica da formação e desenvolvimento da economia brasileira. $3^{\mathrm{a}}$ ed., São Paulo: brasiliense, 1984, p.13.
} 
schumpeterianos")". ${ }^{8}$

No entanto, essa descrença no empresário schumpeteriano tem sentido apenas quando se considera a segunda metade do século $\mathrm{XX}$ com o processo de reestruturação dos setores produtivos na forma de oligopólios. ${ }^{9}$ Mas, até o século XIX o crescimento econômico dependeu em grande parte da ação empreendedora individual apesar do estado colonial português ter o arcaísmo como projeto. ${ }^{10}$ João Luis Fragoso, analisando a praça mercantil do Rio de Janeiro (1790-1830) contestou o caráter extrovertido da economia colonial exportadora, mostrando que apesar das crises e oscilações da economia internacional houve acumulação endógena de capital e a ampliação do mercado interno por meio do aumento das exportações. ${ }^{11}$ Por sua vez o projeto Capanema proposto ao rei D. Pedro II em 1861 se baseou no incentivo a iniciativa particular por meio de prêmios e de investimentos na modernização da agricultura e da pecuária, as principais atividades econômicas cearenses.

Virgílio Noya Pinto constatou a mudança do eixo econômico do Norte para o Sul diante da decadência da agricultura tradicional brasileira "e pela impotência interna em reestrutura-se (falta de capitais, ausência de renovação das técnicas, carência de mão-de-obra etc.)" 12 o que teria neutralizado, "em grande parte, a região Norte e Nordeste do Brasil". ${ }^{13}$ Essa perda dos mercados dos produtos tradicionais: açúcar, algodão e tabaco produzidos pelo Norte e o

\footnotetext{
${ }^{8}$ Ibid., p.94.

${ }^{9}$ RATTNER, Henrique. Empreendedorismo no capitalismo tardio. Revista Espaço Acadêmico, n. 43 - Dezembro de 2004, p.1.

10 FRAGOSO, João, FLORENTINO, Manolo. O arcaísmo como projeto: mercado atlântico, sociedade agrária e elite mercantil em uma economia colonial tardia, Rio de Janeiro (1790-1840). $4^{\mathrm{a}}$ ed., Rio de Janeiro: Civilização Brasileira, 2001, p.224.

11 FRAGOSO, João Luís. Homens de Grossa Aventura: acumulação e hierarquia na praça mercantil do Rio de Janeiro (1790 -1830). 2a ed., Rio de Janeiro: Civilização Brasileira, 1998, p. 273.

12 PINTO, Virgílio Noya. Balanço das transformações econômicas no século XIX. In: MOTA, Carlos Guilherme (org.). Brasil em Perspectiva. 15ª ed. São Paulo: DIFEL, 1985, p.134.

13 Ibid.
} 
crescimento da cultura do café na segunda metade do século XIX não geraram a desigualdade entre o Norte e o Sul, pois as províncias do Norte, e especialmente o Ceará, continuaram até a seca de 1877 com um contínuo crescimento econômico. As províncias do Norte não perderem espaço na economia agroexportadora até 1877, o que ocorreu foi um deslocamento do eixo econômico do Norte para o Centro-Sul devido à importância comercial do café. Em decorrência disso, as províncias do Norte perderam o bonde da industrialização que se deu no CentroSul no século XX. Como observou João Manuel Cardoso de Mello o desenvolvimento do Brasil, não foi desigual, mas tardio em relação ao mundo industrializado porque o "capital industrial nasceu como desdobramento do capital cafeeiro empregado". ${ }^{14}$ Porém, o Ceará mudou em razão da seca de 1877 sua política econômica, passando a incentivar a atividade manufatureira e relegando a um segundo plano a agroexportação. Por isso, esse estado e possivelmente a própria região não tiveram como financiar sua industrialização no mesmo período que o Sudeste, tornando-a retardatária em relação ao Centro-Sul do país.

Nesse sentido, não houve como destacou Noya Pinto impotência interna da região em se reestruturar, o que houve foi um esforço de reestruturação ou de re-equiparação centrado na dependência do investimento público e do próprio Estado. Com isso, o atraso do progresso material do Ceará no século XIX e o seu subdesenvolvimento no século XX decorreu da implantação do projeto Pompeu Sinimbú. O senador cearense ao propor que se utilizasse a mão de obra disponível durante as secas para realizar obras públicas adicionou à prática do socorro direto (distribuição de alimentos) a do socorro indireto (obras públicas). Essa modalidade de socorro se tornou dominante com a criação da Superintendência de Estudos e Obras Contra as Secas (SEOCS) em 1901. Esse

\footnotetext{
${ }^{14}$ MELLO, João Manuel Cardoso de. Op. cit., p.100.
} 
órgão marcou o início do processo de institucionalização do problema das secas que culminou com a fundação da Superintendência para o Desenvolvimento do Nordeste (SUDENE) em 1959. ${ }^{15}$

Portanto, o debate político travado no Brasil no século XX sobre os meios de enfrentar a questão das estiagens remonta a meados do século XIX, quando houve a implantação de um projeto de desenvolvimento material do Ceará e das demais províncias do Norte, proposto pelo senador Pompeu que consistiu no combate às secas por meio da construção de obras públicas. Nesse sentido, a intenção do governo Lula (2003-2010) de realizar a transposição das águas do rio São Francisco, por meio do Ministério da Integração Nacional, do qual fez parte o cearense Ciro Ferreira Gomes, segue a concepção primitiva de combate às secas, elaborada oficialmente em 1878, pelo visconde e presidente do Conselho da Coroa João Lins Vieira Cansanção de Sinimbú, aliado político do senador Pompeu.

De acordo com o Boletim Regional de 2006 “A redução das desigualdades regionais constitui um objetivo estratégico das ações do governo federal". ${ }^{16}$ Portanto, a criação desse ministério (e a necessidade de integrar uma parte do território brasileiro ao conjunto da Nação), a fundação de organismos de desenvolvimento regional como o DNOCS, a SUDENE, o Banco do Nordeste do Brasil (BNB) e a própria definição de região Nordeste fazem parte de um único movimento histórico cujo início se deu com a execução do projeto Pompeu

\footnotetext{
${ }^{15}$ A linha cronológica do processo de institucionalização do problema das secas obedece a seguinte ordem: SEOCS (1901), IOCS (1909), IFOCS (1919) DNOCS (1945) e SUDENE (1959). O que todos esses organismos tiveram em comum foi a presença do estado investindo no progresso e/ou no desenvolvimento da região. É importante ressaltar que não confundimos progresso material como desenvolvimento. A noção de progresso material vigente no século XIX se ateve à aquisição de infra-estrutura e melhoramento tecnológico numa economia agro-exportadora. Já o conceito de desenvolvimento se refere ao processo de industrialização. Entretanto, seja no contexto do século XIX ou no do XX a preocupação foi basicamente a mesma: a diferença do progresso econômico entre as regiões Norte e Sul do Brasil.

${ }^{16}$ CANO, Wilson. Boletim Regional: informativo da política Nacional de Desenvolvimento Regional. Publicação quadrimestral do Ministério da Integração Nacional (janeiro-fevereiro-marçoabril), 2006, p. 16.
} 
Sinimbú durante a seca de 1877-79. A partir disso, poderemos entender porque no Nordeste e no Brasil vigora ainda uma perspectiva de desenvolvimento econômico regional associada à realização de grandes obras públicas.

O projeto Pompeu Sinimbú teve por base as diferenças entre o Norte (que depois veio a ser Nordeste) e o Sul do Brasil, que se tornaram parte do discurso político das elites imperiais na segunda metade do século XIX. Desse período em diante foi crescente o processo de diferenciação entre as duas partes do Império. E essa diferenciação se tornava cada vez mais efetiva na medida em que a parte Sul do país dispunha de melhoramentos materiais como as estradas de ferro símbolo de progresso, civilização e crescimento econômico. A implementação desse projeto de desenvolvimento ocorreu marcado por disputas políticas locais e nacionais, mas também acompanhado de um importante debate técnico que questionava as suas diretrizes fundamentais, como ocorreu durante as sessões do Instituto Politécnico no Rio de Janeiro em 1878.

Com isso, voltamos ao século XIX quando o debate entre o projeto Capanema e o projeto Pompeu Sinimbú estava sendo travado e a seca como obstáculo ao progresso material da região ainda não era um consenso. Nesse período o projeto Pompeu Sinimbú foi executado conciliando socorros públicos diretos e socorros públicos indiretos por meio das comissões instaladas nas diversas vilas e cidades próximas ao litoral. Isso atraiu multidões de desvalidos retirantes provocando o recrudescimento da violência, a proliferação de doenças como a varíola e o beribéri e a exploração sexual das mulheres. Os retirantes eram abarracados e empregados na construção de obras públicas como pontes, estradas açudes, cemitérios, igrejas e na reforma de prédios públicos.

A razão de escolhermos estudar o Ceará foi que o projeto Pompeu 
Sinimbú oficializado em 1878, apesar de estar voltado para as províncias do Norte foi efetivamente implementado no Ceará por força das elites locais, tornando a província o epicentro daquilo que se convencionou a chamar de Nordeste. Assim, a historiografia que aborda essa região se divide em duas vertentes principais: a que procura fazer a defesa da região e outra que denuncia os malefícios da regionalidade. No entanto, nenhuma delas se atém ao processo histórico que criou as condições para o surgimento da região e da identidade regional. A noção de "Nordeste" surgiu atrelada à seca, mas isso somente foi possível devido às mudanças políticas como a ascensão do gabinete liberal Pompeu Sinimbú e a implantação de um projeto de crescimento econômico baseado na exploração da mão de obra do trabalhador sertanejo para a realização de obras públicas que melhorariam a infra-estrurua material da província.

Quanto ao recorte temporal partimos do discurso do senador Pompeu em 1869 e terminamos em 1905 com o presidente da província Nogueira Acióli usando o termo "Nordeste" num relatório. O Ceará nesse interregno foi perpassado por quatro secas principais: 1877-79, 1888-89, 1898 e 1900. Por conta disso, na primeira metade dos séculos XIX até a seca de 1877 o principal problema social e político que preocupava os governos da província e o governo Imperial era a violência. Mas o ano de 1877 foi marcado pelas secas como um acontecimento político e econômico que envolveu a população e as autoridades locais, tornou-se o foco social de substituição à violência.

Nesse período, as comissões de socorros públicos tiveram um papel importante no enfrentamento das estiagens. Já no final de 1900, o Ceará viveu a última seca do século XIX, quando as comissões desempenharam pela última vez um papel central nos socorros públicos. Depois disso se viu um crescente processo 
de institucionalização no nível federal da política de combate às secas com a criação da Superintendência de Estudos e Obras Contra as Secas (SEOCS) em 1901. Com a fundação desse órgão emergiu também uma noção de território (Nordeste) e de identidade regional (nordestinos). Portanto, Manuel Correia de Andrade ao procurar conceituar o Nordeste não percebeu a que região ora apontado como "a área das secas", ora como a "área essencialmente subdesenvolvida devido à baixa renda per capta dos seus habitantes" ${ }^{17}$ é apenas a continuação uma da outra.

Com isso, revemos a noção corrente na historiografia que aborda a política de desenvolvimento regional, segundo a qual o Nordeste foi alvo de uma política de desenvolvimento econômico com planejamento somente após a criação da SUDENE em 1959. ${ }^{18}$ Mostramos, porém que de 1869 a 1905 houve a implementação de um projeto político de desenvolvimento econômico para o Ceará e as demais províncias do Norte que partiu da seca como um impeditivo ao desenvolvimento econômico da província. E mais, que a seca deveria ser combatida por meio de grandes obras de infra-estrutura como açudes e estradas de ferro. A SUDENE e o Banco do Nordeste do Brasil são as versões mais recentes do processo de institucionalização do problema das secas que começou em 1901 com a criação da SEOCS e a separação definitiva entre socorros públicos diretos e socorros públicos indiretos, cujas bases foram estabelecidas em 1878 com o projeto Pompeu Sinimbú.

Nesse sentido, as raízes do atraso material ou do subdesenvolvimento

\footnotetext{
17 ANDRADE, Manuel Correia de. A Terra e o Homem no Nordeste. $3^{\mathrm{a}}$, São Paulo: Editora brasiliense, 1973, p. 3. Andrade interpreta a região a partir da questão da apropriação do solo. Essa obra foi influenciada por Caio Prado Júnior e pelo movimento da Reforma Agrária que era muito ativo na época. $\mathrm{O}$ autor formulou uma interpretação da formação da região que extrapolou os limites da geografia tradicional sobre a região, ressaltando como um traço essencial da região que a diferenciou das demais: o processo de apropriação e ocupação do solo.

${ }^{18}$ VIDAL, Francisco Carlos Baqueiro. Op. cit., p.15.
} 
do Nordeste em relação ao Centro-Sul, alvo das preocupações de Celso Furtado, não vão estar ligadas à dependência do Norte em relação ao Sul. ${ }^{19}$ Como observou Joseph A. Shumpeter o desenvolvimento econômico não é um fenômeno a ser explicado economicamente, mas que a economia em si mesma sem desenvolvimento econômico, é arrastada pelas mudanças do mundo à sua volta, e que as causas e as explicações do desenvolvimento devem ser procuradas "fora do grupo de fatos que são descritos pela teoria econômica". ${ }^{20}$ No caso do Ceará são os fatos de natureza política, econômica e histórica que nos permitem compreender as razões do subdesenvolvimento da região Nordeste.

Para chegar aos resultados alcançados por essa pesquisa foi fundamental a coleta das fontes foi feita no Arquivo Público do Estado do Ceará (APEC), no setor de microfilmagem da Biblioteca Pública do Estado do Ceará (BPEC) e no Instituto do Ceará (IC), na Biblioteca Nacional do Rio de Janeiro (BNRJ) e no Centro de Demografia Histórica da América Latina (CEDHAL). O conjunto dessa massa documental se compõe dos Relatórios de Presidentes de Província e Estado, da documentação administrativa das Comissões de Socorros e Obras Públicos, das revistas do Instituto Histórico e Geográfico do Ceará e da correspondência do Barão de Capanema e do senador Pompeu, além é claro da produção da intelectual da Comissão Científica de Exploração.

Parte do levantamento estatístico foi feita por meio da pesquisa dos relatórios, uma documentação que apesar de desvalorizada por alguns historiadores por considerá-la sumamente política, mostrou-se com a leitura efetiva bastante profícua no que concerne à análise dos discursos e a produção de

${ }^{19}$ FURTADO, Celso. Uma política de desenvolvimento para o Nordeste. Novos Estudos Cebrap. São Paulo: v.1, 1, p.14.

${ }_{20}$ SCHAMPETER, Joseph A. Teoria do Desenvolvimento Econômico: uma investigação sobre lucros, capital, crédito, juro e ciclo econômico. São Paulo: Abril Cultural, 1982, p.47. 
dados estatísticos. Além disso, os relatórios foram o meio encontrado pela política centralizadora do Segundo Reinado para aferir as administrações provinciais. Já a documentação das comissões de socorros públicos nos permitiu compreender o modo pelo qual os desvalidos eram atendidos e a dimensão dos recursos empregados. Nesses documentos ficamos sabendo das famílias assistidas, dos alimentos que recebiam, dos serviços em que eram empregadas, dos valores pagos aos homens e as mulheres, da organização e funcionamento dos abarracamentos e do tipo de obra pública empreendida pelas comissões das vilas e cidades cearenses.

Cada vila e cidade cearense, por meio de abaixo-assinados, pleiteavam durante as secas junto ao governo provincial a formação de uma comissão de socorros públicos para assistir aos desvalidos. Depois de formada e autorizada pelo governo a comissão passava a receber gêneros e verbas do governo da província. Os documentos por ela produzidos como a relação dos trabalhadores empregados nas obras públicas, quantidade de gêneros distribuídos, famílias pertencentes ao local da comissão e famílias retirantes, estado de saúde da população, saques e ações de massa, conflitos entre comissários e a pequena elite local etc. Tudo isso, resultava de determinações do governo provincial de acompanhar a administração dos recursos destinados pela verba - socorros públicos - a assistência à população famélica e desvalida do Ceará.

Um outro conjunto documental importante foi a correspondência do senador Pompeu. As cartas recebidas pelo senador por importantes políticos do Império como o visconde de Sinimbú, Francisco Otaviano, marquês de Paranaguá, Visconde de Itaboraí, Marquês de Olinda, Visconde do Rio Branco entre outros, indicavam a importância política do senador Pompeu e permitem antever a consubstanciação do que chamamos de projeto Pompeu Sinimbú. Já as revistas do 
Instituto Histórico nos permitem compreender aspectos da história cearense como a Revolta de Pinto Madeira, a questão da pena de morte, as secas e o atraso da lavoura.

Para fechar o último capitulo dessa tese (capítulo 6) utilizamos a correspondência da Comissão Científica de Exploração que permaneceu no Ceará de 1859 a 1861, endereçada ao rei Pedro II e da produção científica dos seus principais membros como o barão de Capanema e Giácomo Raja Gabaglia. A partir da leitura dessa documentação pudemos definir a existência de um projeto oposto ao projeto Pompeu Sinimbú e acompanhar o debate técnico-científico realizado em torno da seca de 1877-79 no Instituto Politécnico. Paralelamente a consecução do projeto liberal cearense postou-se a produção intelectual da Comissão Científica de Exploração com artigos como "Ensaios sobre alguns melhoramentos tendentes à prosperidade da Província do Ceará" de Giácomo Raja Gabaglia e os "Apontamentos sobre secas do Ceará" (1878) e "A seca no Norte" (1901) do Barão de Capanema.

A análise desses documentos nos levou a valorizar e a perceber o evento associado às estruturas sociais como o governo, a justiça, os partidos políticos e a conjuntura econômica e social numa perspectiva teórico-metodológica enfatizada por Christopher Lloyd para quem tarefa do cientista social não é "rejeitar a história événementielle, mas apreender primeiro a relação ontológica entre estruturas e eventos". ${ }^{21}$ Nesse sentido, Durval Muniz de Albuquerque Jr. ao preconizar que o Nordeste foi inventado discursivamente ${ }^{22}$, minimizou a importância das condições históricas em que isso ocorreu como mudanças estruturais na relação político-partidária, nas disputas econômicas entre as regiões

${ }^{21}$ LLOYD, Christopher. As Estruturas da História. Rio de Janeiro: Jorge Zahar Ed. 1995, p.72.

${ }^{22}$ ALBUQUERQUE, Durval Muniz de. A Invenção do Nordeste e outras artes. $3^{\mathrm{a}}$ ed. Recife: FJN, Ed. Massangana; São Paulo: Cortez, 2006, p.68. 
Norte e Sul e na criação de órgãos para administrar os socorros públicos aos desvalidos como as comissões de socorros e obras públicas.

Esse modelo se constituiu na medida em que as secas foram incluídas no rol dos principais problemas brasileiros - desde o século XIX - como a má distribuição da renda, a concentração fundiária, a violência urbana e o analfabetismo. Esse estudo segue, de certo modo, a senda proposta por Gilberto Freyre de se estudar os principais problemas brasileiros associados à formação social do próprio homem. ${ }^{23}$ Entre os problemas arrolados por ele nós escolhemos a relação entre homem e progresso material, pois quando se pensa em subdesenvolvimento no Brasil, lembra-se logo da seca e quando se fala em seca, pensa-se em retirante. Com isso, ligamos o surgimento do Nordeste e dos nordestinos ao processo de execução do projeto Pompeu Sinimbú, que explica a existência do Nordeste não apenas como uma entidade cultural, mas essencialmente como uma entidade político-econômica.

Ao negligenciar as estruturas históricas Durval Muniz não percebeu que o crescente processo de institucionalização das secas começou em 1901 com a criação da SEOCS e que se passou a falar em "Nordeste", já em 1905 e não em 1910 (como demarcam alguns estudiosos do assunto) com o presidente da província Nogueira Acióli usando o termo num relatório. Porém, esse processo de institucionalização se deu ao longo da segunda metade do século XIX, a partir de transformações efetivas na vida política e econômica do país que reverberaram no Ceará. O conceito de região é importante nesse trabalho, porém ele tem por base seu aspecto estrutural e funcional associado às mudanças históricas. Com isso, procura-se articular essa funcionalidade analítica à necessidade de se tratar o

${ }^{23}$ FREYRE, Gilberto. Além do apenas moderno: sugestões em torno de possíveis futuros do homem, em geral, e do homem brasileiro, em particular. Rio de Janeiro: Livraria José Olympio Editora, 1973, p.234. 
espaço de maneira não anacrônica, procurando compreender tanto sua dinâmica própria a partir de fontes documentais, quanto o específico da transformação nas concepções de espaço no período analisado. ${ }^{24}$

Nesse sentido, Luis de Aguiar Costa observou que "antes do laço territorial aparecer estreitando as unidades familiais em comunidades de âmbito maior" 25 , a família era o quadro onde se desenrolavam todas ou quase todas as atividades sociais, e que determinava "fundamentalmente, o status da pessoa". ${ }^{26}$ No Nordeste a formação do laço territorial se deu de modo acoplado ao processo de institucionalização do problema das secas. Este por sua vez levou a dissolução da família enquanto uma unidade familiar que era a base da sociedade cearense. A seca ao se tornar um assunto de estado criou uma estrutura burocrática para administrá-la, corroborando o crescente processo de diferenciação territorial entre as províncias do Norte e as províncias do Sul.

O esfacelamento da organização familiar pela seca a partir de 1877 ocorreu à medida que a população precisou migrar abandonando os seus domicílios submetendo à chefia da família a ingerência dos comissários de socorros. Com isso a honra e a valentia foram sobrepujadas, nos anos de secas, pela submissão geral e necessidade de sobrevivência. Os defloramentos no Ceará colonial tratados de modo violento pelos chefes de famílias deram lugar, como ressaltou R. Magalhães Jr. à exploração das mulheres pelos “tipos endinheirados, com a concordância das famílias famintas e, por isso, resignadas com a 'transação ignóbil'”. ${ }^{27}$ O projeto Pompeu Sinimbú também interrompeu o processo de

\footnotetext{
${ }^{24}$ CUNHA, Alexandre Mendes, SIMÕES, Rodrigo Ferreira, PAULA, João Antonio de. História Econômica e Regionalização: contribuição a um desafio teórico metodológico. Estudos Econômicos. Vol. 38, n. 3: São Paulo, jul./setembro, 2008, p.2.

${ }_{25}$ PINTO, Luis de Aguiar Costa. Lutas de Famílias no Brasil: introdução ao seu estudo. $2^{\mathrm{a}}$ ed., São Paulo: Ed. Nacional; [Brasília]: INL, 1980, p.3.

${ }^{26}$ Ibid.

${ }^{27}$ MAGAlHÃes JR. R. A vida turbulenta de José do Patrocínio. Rio de Janeiro: Editora Sabiá,
} 
repressão à criminalidade, iniciado pelo Ministério Eusébio após o regresso conservador.

Criminalidade e violência que, segundo Antonio Otaviano, se estendeu ao espaço cearense, atingindo as famílias e os domicílios do final do século XVIII a meados do século XIX. ${ }^{28}$ Essa questão aparece também no estudo de Maria Silvia de Carvalho Franco quando ela percebeu a importância da violência numa sociedade marcada pelo culto da valentia se referindo à sociedade cafeicultora do Vale do Paraíba, na segunda metade do século XIX. ${ }^{29}$ No entanto, para o Ceará e as províncias do Norte esse aspecto cultural organizador das relações sociais no sertão esmaeceu diante de um sertanejo combalido moralmente pela miséria geral. Ao interromper a política de repressão à violência no Ceará o projeto Pompeu Sinimbú restabeleceu uma das causas do atraso da região, segundo a opinião de Giácomo Raja Gabaglia.

Tanto a violência quanto à situação estacionária da agricultura e da pecuária remetem a uma natureza interna do problema do atraso material da região Norte. Nesse sentido, Joseph A. Shumpeter entende por desenvolvimento (ou progresso material), portanto, "apenas as mudanças da vida econômica que não lhe forem impostas de fora, mas que surjam de dentro, por sua própria iniciativa". ${ }^{30}$ Porém, o projeto Pompeu Sinimbú de desenvolvimento econômico ocorreu de fora para dentro e o instrumento que o viabilizou foram as comissões de socorros públicos. Disso surgiu um outro conceito, o de homo calamitas (homem calamidade). Ele foi apreendido através da análise das consequiências econômicas

\footnotetext{
1969 , p.67.

28 VIEIRA Jr., Antonio Otaviano. Entre paredes e Bacamartes: história da família no sertão (1780-1850). Fortaleza: Edições Demócrito Rocha; Hucitec, 2004, p.168.

${ }^{29}$ FRANCO, Maria Sylvia de Carvalho. Homens livres na ordem escravocrata. São Paulo: Ática, 1997, p.41.

${ }^{30}$ SCHAMPETER, Joseph A. Op. cit, p.47.
} 
para as localidades onde eram instaladas as comissões de socorros públicos.

Nesses lugares houve aumento da inflação, escassez de alimentos, falta d'água, tensão entre os retirantes e a população das vilas ou cidades, exploração sexual de mulheres e moças, desorganização do comércio local e abandono das localidades onde havia possibilidade de sobrevivência em direção às comissões. $\mathrm{O}$ conceito de homo calamitas se atribui aos personagens envolvidos na seca como os comissários, e a própria elite dos diversos lugares que se apropriou dos socorros públicos. A seca não foi o motivo da calamidade por que passou o Ceará, mas a consecução de um projeto de assistência aos desvalidos, calcado em mudanças estruturais na política e na economia, gerido por uma elite que ao chegar ao poder pautou o progresso da região na difusão da calamidade e do assistencialismo, através da instalação das comissões de socorros públicos.

O projeto Pompeu Sinimbú discriminou a população em “desvalidos”, "válidos" e "inválidos". Os desvalidos eram todas as pessoas consideradas incapazes de sobreviverem durante as secas pelos seus próprios meios materiais. Já os sertanejos válidos e inválidos eram aqueles cujo trabalho poderia ou não ser explorado. Porém, nem todo desvalido era um retirante porque o desvalido que fosse atendido por uma comissão de socorros instalada numa vila onde ele residia era chamado de domiciliário, mas aquele que migrasse para além dos limites da vila era chamado de retirante.

Assim podemos ampliar o conceito de homo calamitas para o de estrutura de assistência calamita, porque o projeto Pompeu Sinimbú ao levar os socorros públicos às vitimas das secas disseminou a calamidade para melhorar a estrutura material da província. Nesse sentido, a noção de civilização associada a progresso material e moral se dissociou, e pode-se dizer que o progresso material 
alcançado pela província se deu à custa da enorme mortalidade da população pelos caminhos do sertão, diante da humilhação imposta pelos comissários e chefes de turmas, do açoite das epidemias de varíola e beribéri e da exploração sexual das mulheres. No século XIX o conceito de civilização se dividia basicamente em civilización associado ao progresso material das cidades e o termo alemão kultur associado ao desenvolvimento espiritual. ${ }^{31}$ No Ceará o projeto Pompeu Sinimbú de desenvolvimento econômico embora tenha representado a cada seca a ampliação dos melhoramentos materiais foi implementado em detrimento da aniquilação moral da população sertaneja.

A difusão da seca por meio da imprensa nacional alçou o Ceará a categoria de a mais notável das províncias desvalidas. Ocorreu que se criou uma maior dependência dessa província em relação ao estado no Império e na República, porque como observou José Murilo de Carvalho as elites do Norte eram mais propensas a apoiar o governo imperial devido a sua dependência em relação aos cargos públicos.

Desse modo, para ele a combinação entre estatismo e reformismo era mais fácil para os "magistrados nordestinos, sobretudo para os que provinham de províncias onde o problema da mão-de-obra escrava não era tão sério, como o Ceará”. ${ }^{32}$ Muitos dos funcionários públicos nordestinos tinham no estado sua principal fonte de renda dada a má situação econômica de suas províncias. ${ }^{33}$ Essa má situação financeira do Norte se ligou ao processo de consolidação do atraso material da região, devido justamente ao modelo de crescimento econômico aplicado.

\footnotetext{
${ }^{31}$ LARAIA, Roque de Barros. Cultura: um conceito antropológico. $4^{\mathrm{a}}$ ed. Rio de Janeiro: Jorge Zahar, 1992, p.24-29.

${ }^{32}$ CARVALHO, José Murilo de. A construção da ordem: a elite politica imperial. Teatro de Sombra: a política imperial. Rio de Janeiro: Civilização Brasileira, 2003, p.222.

33 Ibid.
} 
Para efeito didático apresentamos os resultados dessa pesquisa em 4 capítulos. No Capítulo 1, "Violência: calamidade política e econômica" nós mostramos que no Ceará após o regresso conservador a violência se tornou um problema importante, na medida em que era vista como um empecilho ao progresso econômico da província. O combate à violência nas províncias do Norte fez parte do projeto de consolidação do estado nacional brasileiro e houve até 1876 uma contínua política de perseguição aos criminosos.

No Capítulo 2: "A seca de 1877 e a lei forçada do senador Pompeu" mostramos como a seca de calamidade natural se tornou uma calamidade política devido à aplicação de um projeto que objetivava realizar o progresso material no Ceará por meio das obras de socorros públicos, com o objetivo de corrigir a crescente disparidade econômica entre as províncias do Norte e as províncias do Sul. O resultado disso foi que as medidas de socorros aos sertanejos desvalidos em troca de trabalho que já vinham sendo tomadas no primeiro ano da seca (1877) ganharam ainda mais apoio econômico no segundo ano (1878) com a ascensão do gabinete liberal Sinimbú e com isso, a seca passou a sobrepujar em importância aos demais acontecimentos.

No capítulo 3 "Da agroexportação à atividade manufatureira", nós mostramos que a partir da seca de 1877 houve uma mudança do pensamento econômico. Deixou-se de acreditar no potencial de crescimento econômico baseado na agricultura para uma política econômica estribado na atividade manufatureira. No entanto, até esse ano esses dois setores se mantiveram entrelaçados, de modo que o crescimento da agroexportação impulsionava o desenvolvimento da indústria manufatureira. Essa desconexão surgiu da descrença advinda com a seca e o seu impacto sobre a agricultura e a pecuária. Com isso, os 
governos provinciais tentaram, por meio de uma política de incentivos fiscais, promoverem o desenvolvimento da atividade manufatureira, relegando a agricultura a um papel de segunda categoria.

Essa mudança do pensamento e da política econômica se distinguiu do Centro-Sul do Brasil, pois nessa região os capitais advindos da lavoura cafeeira ajudaram a alavancar a industrialização. Nesse ponto, concordamos com João Manoel Cardoso de Mello quando este afirma, antepondo-se ao pensamento cepalino, que o desenvolvimento do Brasil não foi desigual, mas tardio porque dependeu da acumulação endógena do capital cafeeiro.

Nesse sentido, o desenvolvimento do Ceará e das províncias do Norte foi comprometido pela ruptura entre a agroexportação e a atividade manufatureira com a aceitação pelas demais províncias da noção advogada pelo projeto Pompeu Sinimbú de que a seca era um óbice ao progresso material da região e que somente seria suplantado esse problema com a intervenção e o apoio do governo central.

Por isso no Capítulo 4 - "As elites políticas e o projeto Pompeu Sinimbú" - defendemos a noção de que as elites cearenses e as demais elites do Norte perceberam as vantagens monetárias trazidas pelas secas. Com isso, as secas se tornaram a tônica dos discursos políticos porque durante seus episódios era possível encaminhar a realização de obras públicas obstadas durante os períodos de regularidade climática, em razão do déficit entre a receita e a despesa resultante do clientelismo e da corrupção dos governos cearenses, sobretudo com a consolidação no poder da oligarquia Acióli. 


\section{Capítulo 1 - Violência no Sertão: problema político e econômico, 1840-1876.}

O objetivo deste capítulo é mostrar que no Ceará entre 1840 e 1877 a violência era o principal problema político e social, mas com a eclosão da chamada "grande seca" (1877-1879) ela foi sobrepujada em importância, tornando-se uma calamidade, cujos efeitos foram sentidos pela população, sobretudo pela mais pobre. É preciso, no entanto, considerar que tanto a seca quanto a violência não eram apenas fenômenos sociais, mas históricos, ou seja, estavam relacionados à conjuntura do Brasil no período.

Conjuntura essa formada pelas Revoltas Regenciais, a Conciliação, as diferenças econômicas entre o Norte e o Sul e as disputas políticas entre liberais e conservadores. Assim, os episódios de violência ou as imagens de retirantes cadavéricos devem ser entendidos como parte de uma estrutura mais ampla na qual estavam inseridas. Nesses termos, distinguimos dois tipos de calamidade: calamidade natural e calamidade política. Tanto num modo quanto noutro a população foi o pêndulo para se avaliar os efeitos dessas calamidades.

\section{1. - Episódios de penas de mortes.}

O filólogo Francisco da Silveira Bueno definiu calamidade como “desgraça geral, sofrimento, provação e castigo público”. ${ }^{1}$ Porém, o uso dessa noção de calamidade adquiriu historicamente em relação ao Ceará no século XIX duas variações importantes: calamidade natural e calamidade política.

\footnotetext{
${ }^{1}$ BUENO, Francisco da Silveira. Dicionário da Língua Portuguesa. São Paulo: Edições Fortaleza Crédito Brasileiro de Livros S.A., 1972, p.192.
} 
Entendemos o termo "natural" não como algo relacionado à natureza, mas no sentido de normal, regular, espontâneo e ingênito como prediz o dicionarista. As noções de "calamidade natural" e "calamidade política" se aplicaram no Ceará a fenômenos diversos como as secas, as enchentes (climáticos) e a violência (social) perpetrada pelo governo e pela população. O uso variável desses termos em relação à violência ou as secas dependeu das condições políticas e econômicas estabelecidas historicamente.

A violência como calamidade natural perpassou o Ceará de 1780 a 1850, quando a região viveu sob um estado de agressões mútuas, como avaliou Antonio Otaviano Viera Jr. De acordo com ele "os cotidianos de mulheres e homens cearenses foram entrecortados, nas mais diversas direções, pela presença constante da violência". ${ }^{2}$ Esta era utilizada não apenas pelos cearenses, mas plasmava as relações sociais e políticas em todo o Norte do Brasil. Nessa região havia uma particular potencialização dos conflitos devido à dureza do cotidiano castigado por intempéries como as enchentes e as secas, mas, sobretudo por uma repartição sumamente desigual da propriedade da terra, assentada desde o século XVI no regime de capitanias hereditárias que era a base econômica para os desmandos políticos. Com isso, os homens pobres e livres dependiam da vontade dos senhores de engenhos, dos capitães e coronéis da Guarda Nacional, dos criadores de gado, ou de quaisquer proprietários que lhes dessem trabalho e abrigo.

A concussão de ações violentas entre os cearenses envolvia desde o pequeno roceiro ao mais abastado latifundiário, posto que estavam ligados, e não se restringia ao âmbito do domicílio, estendendo-se sobre o espaço público das vilas e cidades, esgarçando o tecido social em renhidas lutas familiares e eleitorais. Práticas

\footnotetext{
${ }^{2}$ VIEIRA JR., Antonio Otaviano. Entre Paredes e Bacamartes: história da família no sertão (17801850). Fortaleza: edições Demócrito Rocha; HUCITEC, 2004, p.161.
} 
violentas eram presentes nas diferentes esferas sociais, durante as secas, nas disputas judiciais pela posse da terra e na conservação pela força de valores morais como a honra e a bravura masculina. Estes valores eram baseados, sobretudo, na dignidade individual, cuja não observância por parte de alguns membros das localidades, tornava-os transgressores, levando ao cometimento de espancamentos, assassinatos, tocaias e emboscadas como meios de resolução, quase sempre provisória, das pendências familiares e jurídicas.

O deputado provincial João Brígido dos Santos concluiu a respeito das lutas entre famílias, que a organização da sociedade cearense era dominada por abastados proprietários de terras, que se tornaram no século XVIII e até meados do XIX cada vez mais insolentes à medida que crescia a riqueza do país. Isso ocorria porque os coronéis fazendeiros, segundo ele, tinham sob seu domínio verdadeiras "hordas selvagens reduzidas à obediência". ${ }^{3}$ De posse de armas como bacamartes e facas, longe do olhar das autoridades localizadas na Corte, primeiro em Salvador depois no Rio de Janeiro - e outrora, além mar - esses homens viviam em perfeita licença e dominavam os outros colonos do modo mais completo. Quanto mais distante o rincão, mais se destacava o império da vontade do régulo mais abastado e protegido por laços de parentescos, de modo que a lei e o dever eram coisas inteiramente ignoradas.

A riqueza e a família eram de fato as duas condições para o domínio dos latifundiários sobre a população pobre. A conjugação desses elementos permitia ao potentado local ignorar as leis e perturbar a ordem. O governo central se fazia inoperante em razão da geografia que separava as decisões régias da sua aplicação. Na primeira metade do século XIX o país enfrentou turbulências políticas para se

\footnotetext{
${ }^{3}$ CARVALHO, Jader de. Antologia de João Brígido. Fortaleza-ce: Editora Terra de Sol, 1969, p.561-
} 596. 
efetivar como estado. Porém, como observou Evaldo Cabral de Mello “O Brasil não se tornou independente porque fosse nacionalista, mas fez-se nacionalista por haverse tornado independente". 4 A nação foi algo construído após a independência, marcada pelo uso da força por parte dos regentes e do Imperador num esforço de pacificação pela sufocação das revoltas locais contra o poder régio ou a favor dele, como foi o caso da Revolta de Pinto Madeira em 1830 no Ceará.

O Brasil enquanto nação se formou de modo gradual e à custa de processos interstícios e cruentos. Na sua fase de Império, passou pelo período das regências, um dos mais complicados, quando ocorreram revoltas como a Cabanagem (1832-1840), a Balaiada (1833), a Sabinada (1833-1838) e a Revolta dos Farrapos (1835-1845). O regente Feijó antevendo essas revoltas contra a Constituição de 1824 criou a Guarda Nacional em 1831, aproveitando-se da relação direta entre política, parentela e violência no sertão. Nas várias localidades onde ocorria eleição para vereadores e juízes de paz, as agressões físicas eram recorrentes. Os presidentes de província do Ceará, na primeira metade do século XIX e ao final de cada gestão, informavam à Assembléia Legislativa Provincial, nos seus relatórios sobre o estado da tranqüilidade pública e da segurança privada, nos quais os atentados cometidos no interior eram relatados com desconforto, sobretudo porque ameaçavam a integridade e a paz do Império.

Com isso, os sucessivos presidentes da província apresentavam relatórios, nos quais eram abundantes os casos de ações violentas perpetradas no sertão cearense pelo domínio político das regiões. Isso levava ao assassinato de autoridades, às irregularidades nas eleições e ao cometimento de desmandos. Por isso o presidente da província em 1851, Francisco Inácio Silveira da Motta, considerou que o combate

\footnotetext{
${ }^{4}$ MELLO, João Cabral de. Um imenso Portugal: história e historiografia. São Paulo: Ed. 34, 2002, p. 15 .
} 
à violência era "reconhecida como a maior necessidade social" 5 , levando-o, por isso, a defender a punição efetiva dos crimes cometidos. Motta em conseqüência disso deu grande importância à edificação e aos reparos das cadeias porque a falta delas, segundo ele, alimentava a impunidade, que tantas raízes haviam lançado sobre a província do Ceará. ${ }^{6}$

À falta de novas cadeias e o estado precário em se encontravam na sua maior parte as existentes, somava-se o uso de armas como o bacamarte, mas, sobretudo a faca de ponta utilizada largamente pelos sertanejos como observou George Gardner, naturalista escocês que visitou o Ceará em 1838. Segundo ele, a população cearense era dominada pela discórdia geral, por ser notavelmente vingativa, cujos conflitos eram resolvidos com o uso da faca de ponta, que quase todos traziam na cintura. ${ }^{7} \mathrm{O}$ uso da faca na cintura era um costume do sertanejo que a utilizava, de igual maneira, nas lides do dia-a-dia e na sua defesa contra agressores. Franklin Távora anotou no seu O Cabeleira, referindo-se a Pernambuco no século XVIII, que os roubos e os assassinatos "reproduziam-se com incrível frequiência nos caminhos e até nas beiradas dos sítios". ${ }^{8}$

Esse estado de agressividade que campeava os sertões também encerrava a maneira como a política era exercida nas tribunas, estando em perfeita ordem com o que ocorria no sertão. O senador José Martiniano de Alencar, chefe do partido liberal no Ceará, envolveu-se no dia 14 de setembro de 1841 numa briga com Cândido José de Araújo Viana, então Visconde de Sapucaí e ministro do Império. No início da sessão houve uma discussão exaltada entre os dois parlamentares quando

\footnotetext{
5 APEC - Relatório do presidente da província do Ceará Ignácio Francisco Silveira da Motta. Tipografia cearense, Rua da Boa vista $n^{\circ} .33,1851$, p. 7.

${ }^{6}$ Ibid.

7 GARDNER, George. Viagem ao interior do Brasil. Belorizonte: Ed. Itatiaia; São Paulo, Ed. da Universidade de São Paulo, 1975, p.84.

${ }^{8}$ TÁ VORA, Franklin. O cabeleira. São Paulo: Três, 1973, p. 4.
} 
Alencar, segundo o jornal Diário do Rio, recorreu "as vias de fato sem dúvida para convencer o nobre ministro!". ${ }^{9} \mathrm{O}$ jornal observou que nada menos era de se "esperar do digno instrumento do Ministério passado, mandado para o Ceará a fim de doutrinar aqueles povos ao sistema do cacete". ${ }^{10}$ O padre Alencar, pai do autor de Iracema, deu umas bofetadas em Araújo que para revidar tentou lhe acertar com uma cadeira, no que foi obstado por Manuel Inácio da Cunha Menezes (Visconde do Rio Vermelho). Apesar do insólito ocorrido houve sessão e Alencar tomou assento como primeiro secretário.

Numa outra ocasião, Alencar governava a província do Ceará quando foi atacado por uma tropa revoltosa, comandada por seus inimigos políticos: Torres, Lins, Jacarandá e outros comparsas. Ao retornar a cavalo com a sua comitiva para Fortaleza o presidente se encontrou com Vicente Lopes, mais conhecido como Vicente Caminhadera, afamado facínora dos sertões que acorreu em seu socorro com homens armados, montados e municiados. Ao se aproximar da comitiva de Alencar, Vicente foi logo se desculpando por não ter sabido antes da revolta e chegado a tempo de auxiliá-lo. O presidente agradeceu a dedicação de seu correligionário, pedindo-lhe que desse os nomes dos homens de seu séquito, inclusive o dele próprio, que fossem acusados de crimes para que pudesse atuar no sentido de serem absolvidos. $^{11}$

Nesse período, entre as províncias do Norte o Ceará era uma das mais violentas. Por isso, em 1835 o senador Alencar observou que no ramo da segurança pública a situação do Ceará era triste e horrorosa, porque faltava a segurança individual e da propriedade, vulgarizando-se os furtos e grassando a impunidade

\footnotetext{
${ }^{9}$ PINTO, José Marcelo de Alcântara. Os barões do Icó. Revista do Instituto do Ceará. Tomo LXVII, 1953, p. 111.

${ }^{10}$ Ibid.

${ }^{11}$ CATUNDA, Th. SOUSA, Eusébio de. A vida de Vicente Lopes de Negreiros. Revista do Instituto do Ceará. Tomo XXXII, 1918, p.301.
} 
geral. Com isso, começou-se "a assassinar nas estradas, passou-se às casas, às praças, às ruas" ${ }^{12}$, e por fim até nos cárceres iam os "assassinos buscar vítimas a sua ferocidade”. ${ }^{13}$ Em 1836 o mesmo presidente disse à Assembléia Provincial que a administração da justiça continuava no pior estado possível porque a impunidade estava no auge, parecendo que "a bonomia dos jurados marchava sempre a par da crueldade dos assassinos. Em 15 meses 37 homicídios!”. ${ }^{14}$

Em 1837, ainda o mesmo presidente, dizia que os assassinatos na província, depois do último relatório, haviam chegado a 24. Felizmente, segundo ele, havia uma diferença de 9 crimes a menos. Essa circunstância lhe dava esperança de que a segurança melhoraria, pois estes assassinatos foram na maior parte o efeito repentino de rixas e brigas de pessoas da última classe da sociedade, e não o resultado desses assaltos sanguinolentos dados por diversos indivíduos prepotentes, que, acompanhados de grandes séqüitos de homens armados, corriam de uma extremidade da província à outra, levando o terror e a consternação a todas as partes. De acordo com Alencar, felizmente, já não se ouviam falar todos os dias dos crimes e ameaças cometidos por Mourões, Malambas, Tetéus, Bem-te-vis, Mata-velhos, Fazfomes, Zolhões, Folgazões e outros cruéis e afamados assassinos que por suas façanhas haviam adquirido celebridade e apelidos consentâneos a suas crueldades. ${ }^{15}$

A preocupação em combater a violência resultava da preocupação em evitar a desestabilização da monarquia defendida tanto por liberais quanto por Conservadores. Por outro lado os crimes contra a segurança individual e a propriedade fragilização o progresso material da região. Assim, apesar dos bons números o presidente Alencar identificava a violência como um gargalo social ao

\footnotetext{
${ }^{12}$ GABAGLIA, Giácomo Raja. Ensaios sobre alguns melhoramentos tendentes à prosperidade da província do Ceará. Rio de Janeiro: Tipografia Nacional, 1877, p.48 e 49.

${ }^{13}$ Ibid.

${ }^{14} \mathrm{Ibid}$.

${ }^{15}$ Ibid., p. 107.
} 
progresso do Ceará:

De certo a primeira e mais urgente necessidade, que temos á de se fazer efetiva a segurança ao menos pessoal, em nossa Província, o Cidadão Cearense não goza daquela convicção de segurança indispensável a qualquer homem para se entregar com eficácia ao desempenho daquilo, a que tenha de se aplicar: o agricultor ao pé de sua lavoura, o criador atrás do seu gado, o viajante nas estradas, o negociante no seu escritório, o empregado público mesmo no seu gabinete, todos receiam a cada instante o punhal, ou o fuzil do assassino. ${ }^{16}$

Em 1843 o presidente J. M. da Silva Bittencourt declarou que o recurso ao bacamarte e ao punhal era tão freqüente nas menores rixas, que espantava ver o menosprezo com que se tinha a segurança individual e a vida. Era preciso, fazer cessar "esta torrente de mal". O presidente Fausto Aguiar em 1848 igualmente se mostrava consternado a cerca da segurança individual, mormente no sertão, onde o bacamarte era "o desforço geralmente adotado para a reparação de suposto gravames, mais filhos da nenhuma ilustração e moralidade dos habitantes do que motivos reais". ${ }^{17}$

As práticas políticas ocorridas no Brasil imperial, mormente na fase das regências, envolveram o país numa série de conflitos violentos, na maior parte das vezes, arraigados de maneira confusa em diferentes interesses e matizes ideológicos como o republicanismo federalista e o monarquismo constitucional que eram as duas tendências que dividiam as elites intelectuais do país. ${ }^{18}$ Elites estas, com homens como Alencar, que arregimentavam facínoras perversos para garantirem seu domínio pelos sertões bravios. Essas duas vertentes eram enfatizadas de modo antagônico

\footnotetext{
16 Ibid.

${ }^{17}$ Ibid., p. 108 .

${ }^{18}$ PINTO, José Marcelo de Alcântara. Op. cit. p.113.
} 
pelo partido liberal e pelo conservador. Com isso, as lutas entre famílias que ocorreram no Ceará, com mais intensidade na primeira metade do século XIX, deviam-se as divergências político-partidárias entre régulos locais, conselheiros e senadores do Império que resvalavam nas províncias.

Pouco tempo depois da abdicação de D. Pedro I ao trono brasileiro, o general francês Pedro Labatut, desembarcou no Rio de Janeiro, como tantos outros mercenários, onde foi admitido ao serviço do Brasil em 3 de julho de 1822, criando o chamado Exército Pacificador. ${ }^{19}$ Oito anos depois ele foi mandado ao Ceará para sufocar a revolta de 1830, liderada por Pinto Madeira, régulo defensor da volta do monarca ao poder, que pertencia a uma sociedade secreta denominada de Coluna do Trono. Labatut compreendeu que seriam necessárias para pacificar aquela província medidas de brandura e o envio de magistrados íntegros, prudentes e sábios que pudessem apagar de uma vez por todas "as lavas da bárbara e cruel guerra civil" ${ }^{20}$, que arrasou a comarca do Crato. No entanto, observou que esta não era a opinião dominante daqueles que com indiferença viam míseras e inocentes famílias dormirem “ao relento debaixo das árvores!”. ${ }^{21}$ Esse é um ponto comum, como veremos adiante, entre a violência e as secas; ambas deixaram as famílias, sobretudo as mais pobres, ao desabrigo do lar, sob o refúgio dos cajueiros.

Prolongava-se a rebelião encabeçada pelo ex-coronel de milícias Pinto Madeira e o vigário do Jardim, cônego Antonio Manoel de Souza, que se alastrou pelo interior da província, quando a bordo do brigue Alcides, desembarcou no porto da capital o general Labatut, enviado pela Regência para debelá-la. Ainda a bordo do navio ele se dirigiu aos cearenses, conclamando-os em nome do regente e do

\footnotetext{
${ }^{19}$ SOUSA, Octávio Tarquínio de Sousa. José Bonifácio. Rio de Janeiro: Biblioteca do Exército, 1974, p. 142 .

${ }^{20}$ NOGUEIRA, Paulino. Execuções de pena de morte no Ceará (parte II). Revista do Instituto Histórico e Geográfico do Ceará. Ano VIII, 1894, p.181.

${ }^{21}$ Ibid.
} 
Imperador Constitucional, Pedro II, alçado ao posto de defensor perpétuo do Brasil, a acabar com a revolta. Poder-se-ia pensar por que a Regência não foi conivente com Pinto Madeira e seu séquito já que ele era monarquista. O problema era que se o regente apoiasse os revoltosos do Crato colocaria em risco o frágil equilíbrio político entre os liberais e os conservadores que davam legitimidade à monarquia.

O mercenário era um homem habilidoso e atilado e por isso, procurou deixar clara a legalidade da sua ação, afirmando que a supremacia do governo era resultante de um estado soberano. Ele recebeu para garantir a supremacia do estado sobre um dissidente local: armamentos, tropas e o apoio do presidente da província para reunir uma força capaz de libertar parte da população cearense da tirania de um régulo, "que na louca mania de sua ambição criminosa e furor canibal" ${ }^{22}$, pretendia estender "seus estragos, latrocínios e mortes sobre todos os pacíficos habitantes do ameno Ceará”. ${ }^{23}$ Se Pinto Madeira era um régulo tirano, como disse Labatut, não era o único, pois vários outros existiam no Ceará a levantar o povo das localidades contra outros régulos e contra os próprios governos.

Com a interpelação das tropas mercenárias, o coronel Pinto madeira e o vigário Antonio Manoel de Souza, já extenuados de uma luta sanguinária de quase dez meses seguidos, perderam as esperanças de vitória. Estavam cônscios, por outro lado, da humanidade com que eram tratados os prisioneiros pelo general Labatut, pois alguns eram postos em liberdade e outros eram recolhidos às cadeias consideradas suportáveis. Convenceram-se, então, de ter chegado à ocasião para deporem as armas, mediante uma única condição: a de o general garantir-lhes as suas vidas e as de seus camaradas, fazendo remeter a ambos para a Corte, onde esperavam justificarem-se perante a Regência. A proposta foi aceita e no dia 3 de novembro os

\footnotetext{
${ }^{22}$ Ibid.

${ }^{23}$ Ibid.
} 
chefes rebeldes cumpriram sua palavra e mais de 3 mil homens depuseram as armas no Correntinho. ${ }^{24}$

Labatut diante de centenas de sertanejos que na sua frente depunham as armas expressou o desejo de puder apagar de uma vez por todas a sede de sangue brasileiro, que abrasava os dois partidos. ${ }^{25}$ Os liberais e os conservadores nas suas lutas políticas desencadearam diversos conflitos, em razão do que avaliou Labatut acerca da política nacional, que se cuidou somente em vingarem-se as paixões particulares, queimarem-se casas, legumes e mobílias, assassinarem-se prisioneiros desarmados e roubar, consubstanciando um cenário no qual se antepunha brasileiro contra brasileiro, a seu ver, uma verdadeira desgraça. ${ }^{26}$

Os presos Joaquim Pinto Madeira e o vigário Antonio Manoel de Souza foram conduzidos a Pernambuco e daí eles seriam enviados a Corte. Mas, os opositores políticos de Madeira começaram uma disputa judicial contra a decisão do general, pois queriam que os réus fossem julgados na comarca dos seus crimes. Pedro Labatut foi acusado por jornais locais e por autoridades influentes de apoiar os revoltosos, que não queriam que os chefes rebeldes fossem remetidos ao Rio de Janeiro. Procedeu-se a esforços para que os acusados fossem julgados na comarca de seus crimes. No entanto, o Crato e todo o Ceará não ofereciam cadeias seguras àqueles réus, que fizeram um périplo digno dos grandes assassinos da história. Foram remetidos a Pernambuco, depois ao Maranhão, de volta ao Ceará no brigue 29 de Agosto, até que foram julgados e condenados.

Ao amanhecer o dia o povo acorreu de modo extraordinário para assistir a consumação do atentado. Às 8 horas saiu o fúnebre préstito em direção a forca, levantada no alto, num lugar chamado Barro Vermelho. O garroteamento foi feito

\footnotetext{
${ }^{24}$ Ibid.

${ }^{25}$ Ibid.

${ }^{26}$ Ibid.
} 
com três linhas de aroeira, de cinco metros de altura cada uma. Na frente ia o porteiro da cadeia Antonio Alves da Silva, apregoando a sentença em voz alta, seguia-lhe o réu, calmo, passo firme, vestido de calça de brim branco e jaqueta de riscado. Conduzia-se entre os seus confessores da agonia, com uma corda de tucum dependurada no pescoço, cujas pontas eram seguradas pelo carrasco Cosme Pereira da Silva, que atendia pela alcunha de Cavaco. Acompanhava mais atrás o juiz de direto interino Antonio Ferreira Lima.

Ao chegar o préstito ao patíbulo, depois de haver percorrido algumas ruas, Pinto Madeira pediu aos seus confessores que obtivessem a comutação da pena em fuzilamento; poupando-lhe desse modo à ignomínia de ser enforcado como um malfeitor, pois ele fora outrora, um coronel de milícias. Então, José Vitorino conferenciando com Moura e Maia, decidiu pelo fuzilamento, mas Moura se opôs alegando em contrário o preceito da lei. Vitorino retrucou afirmando que ou o réu era fuzilado, ou voltava para a cadeia para que pudesse apelar como também era preceito expresso na lei. Moura então aceitou a comutação da pena.

Destacaram-se do pequeno pelotão de fuzilamento cinco soldados da tropa de linha comandados por um cabo de esquadra. Colocou-se uma cadeira de pau presa a um dos varões da forca, e nela sentou-se o condenado. Nessa ocasião, Maia se dirigindo ao réprobo, ofereceu-lhe um lenço para cobrir o rosto, mas ele recusou com certo ar de desdém, dizendo: "Eu também tenho". ${ }^{27}$ Em seguida pediu ao cabo que lhe tirasse do bolso da jaqueta um lenço de seda de ramagens e com este lhe foi coberta a face. Uma descarga certeira deitou-o por terra de bruços, proferindo ele ainda estas últimas palavras:- "Valha-me o sacramento!" ${ }^{28}$, mas um tiro de honra no

\footnotetext{
${ }^{27}$ Ibid, p. 226-227.

28 Ibid.
} 
ouvido acabou de matá-lo. ${ }^{29}$ Esse foi um caso de pena de morte por motivos sumamente políticos que ocorreu no Crato e passou a compor o imaginário político do Ceará.

Sem a mesma dimensão política da revolta de Pinto Madeira, mas igualmente importante para entendermos a atmosfera de violência que pairava sobre a terra cearense foi o assassinato do tenente-coronel José Cavalcanti, chefe da Guarda Nacional de Telha. Quando este se dirigia à vila do Icó para tratar de negócios foi morto a tiros em meio a sua escolta de mais de vinte homens. O corpo foi conduzido de volta à vila, mas ninguém se atreveu a realizar a perícia no cadáver por estarem ali, ainda presentes, os seus assassinos. Temia-se enviar ofício relatando o ocorrido ao presidente Inácio Correia de Vasconcelos, pois poderia ser interceptado pelos facínoras. Encontrou-se, no entanto, um modo inusitado: enviar o ofício entre as canastras de um comerciante de Aracati. Não obstante, os homens principais do lugar abandonaram suas casas, ${ }^{30}$ como Francisco Fernandes Vieira (futuro barão do Icó) e o coronel Agostinho Thomas de Aquino.

Por outro lado, a violência entre os régulos do sertão acabava envolvendo homens pobres e livres, como os agregados, que se viam quase obrigados a cometerem homicídios a mando dos seus senhores. As guerras entre famílias fossem elas abastadas ou pobres, tinham como conseqüência freqüente a perda do domicílio. A despeito do que desejara o general Pedro Labatut, de ver os dois partidos baixarem as armas quando fossem fazer política, o fato era que os potentados locais se assenhoreando da força, quando no poder, levavam seus adversários à forca ou ao fuzilamento como punição pelos crimes cometidos, ou por simplesmente lhes fazem oposição. A justiça se tornava instrumento das vinganças pessoais. Nesse quadro

\footnotetext{
29 Ibid.

${ }^{30}$ Ibid., p. 206 e 2007.
} 
social a família era a referência para a gravidade do problema. Certo preso antes de ser enforcado fez o seguinte discurso "pais de família, tomai exemplo por mim; minha mãe não me deu boa educação, e vejo-me aqui neste lugar em que vou morrer, porque os homens condenaram-me à morte pelos meus crimes". 31

Os homicídios na província eram cometidos por malfeitores, capangas e jagunços que atuavam com violência no sertão a mando de potentados chefes de famílias. As lutas entre famílias no Brasil desde o período colonial eram como observou Luís de Aguiar C. Pinto, um dos primeiros a estudar o assunto, algo que se confundia "com muitos outros, e decisivos, aspectos da formação social brasileira". ${ }^{32}$ Dessa forma, as disputas entre famílias era um aspecto inerente à formação do modelo de estado brasileiro. A organização familiar era a base da dinâmica social. Por esse motivo, os significados associados à família cearense dependiam da sua relação com o domicílio e a violência, ${ }^{33}$ que ocorria tanto no seio das grandes quanto das pequenas famílias proprietárias.

Havia no Ceará uma elite familiar partidária que disputava o poder local: de um lado os chimangos representando os conservadores e de outro os equilibristas, representando os liberais. Dentre os liberais cearenses ninguém foi mais influente na política nacional que Tomas Pompeu de Sousa Brasil. Ele passou a residir no Ceará a partir de 1844, após concluir seus estudos no seminário de Olinda. Desde então se dedicou ao sacerdócio e em 1854 era vigário geral forâneo da Província. Nessa época o Ceará era presidido pelo conselheiro padre Vicente Pires da Mota e o pároco colado era o padre Carlos Augusto Peixoto de Alencar, homem irritadiço que em 1858 teve uma rixa com Tomas Pompeu levando o padre José de Alencar a intervir

\footnotetext{
${ }^{31}$ Ibid, p. 261.

${ }^{32}$ PINTO, Luis de Aguiar Costa. Lutas de Famílias no Brasil. $2^{\text {a }}$ ed. São Paulo: Ed. Nacional; INL, 1980, p.13.

${ }^{33}$ VIEIRA JR., Antonio Otaviano. A familia cearense na seara dos sentidos: domicílio e violência no Ceará. São Paulo: Tese de doutorado, USP/ 2002, p.166.
} 
para apaziguar os ânimos.

Pompeu além das obrigações de sacerdote dirigiu o Liceu do Ceará, onde ensinava geografia e história. Ele conduzia com habilidade seus interesses políticos nunca se excedendo em atos de intolerância ou de desrespeito à dignidade dos adversários. Ao voltar ao Ceará, aderiu segundo ele próprio "franca e lealmente ao partido de [seus] parentes, e família, por convicção, e até por um dever". ${ }^{34} \mathrm{O}$ fato era que os homens de letras tinham poucas chances de aquinhoar pequenos tesouros e reconhecimento sem os holofotes da política e as benesses advindas dos cargos públicos. Os homens de talento do Brasil pós-independência se tornaram requisitados e para isso os mais favorecidos pela fortuna mandavam seus filhos à Coimbra, à Olinda e a São Paulo, donde voltavam doutos advogados, médicos e padres letrados.

Em 1846 com o objetivo de ajudar a agremiação partidária a que pertencia Pompeu decidiu editar o jornal O Cearense, o qual passou a orientar a opinião pública através do fluxo de notícias e artigos. Além de artigos de natureza partidária, Pompeu passou a divulgar estudos sobre demografia, desenvolvimento da vida urbana e estatística. Em 1851 publicou seu Compêndio de Geografia, que se tornou conhecido no país e serviu aos alunos das escolas públicas. Uma edição de 1856 passou a ser adotada no Imperial Colégio Pedro II e nos liceus e seminários do Brasil. Apesar de galgar a admiração dos amigos e correligionários, não foi fácil levar o Senador Alencar a assentir na solicitação de Gregório Francisco de Torres e de Francisco de Paula Pessoa para incluir o nome de Pompeu entre os candidatos liberais à eleição para a assembléia geral de $1845-47 .^{35}$

A eleição se realizou num clima de violência e após ser concluída, os documentos foram remetidos ao Ministério do Império para conhecimento da

\footnotetext{
34 PINTO, Luis de Aguiar. Op. cit, p. 115.

${ }^{35}$ Ibid., p. 117.
} 
Câmara dos Deputados, na sessão de 7 de janeiro de 1845, onde foi lido por Antonio Carlos Ribeiro de Andrada Machado e Silva. O parecer da Comissão de Verificação de Poderes concluiu que fosse anulada a eleição pela província do Ceará para deputados à Assembléia Geral na atual legislatura e que se comunicasse àquela resolução ao governo, para que mandasse fazer com urgência uma nova eleição. A comissão recomendou ainda ao governo da província a adoção de medidas constitucionais adequadas, para se conseguir no Ceará conduzir um processo eleitoral que fosse legítimo, regular e livre.

Em contrapartida à Comissão de Verificação de Poderes os conservadores Miguel Fernandes Vieira e Francisco de Sousa Martins encaminharam à Câmara dos Deputados um pedido de reconhecimento dos candidatos derrotados no pleito, o que não foi aceito, pois a comissão entendia que a fraude eleitoral grassava em ambos os partidos. Somente em 1846 foram diplomados os deputados Tomas Pompeu, Frederico A. Pamplona, Carlos A. P. de Alencar e José V. Rodrigues como deputados leitos pelo Ceará. A anulação de candidaturas ficou conhecida na terminologia política como "degola". Porém, nem todas as degolas ocorriam porque a Comissão de Verificação não queria ver eleitos seus adversários nas suas províncias, em muitos casos a Comissão almejava garantir um mínimo de lisura possível nos processos eleitorais e as degolas eleitorais serviram grandemente para desencorajar as práticas políticas abusivas.

As lutas entre famílias no Ceará embora fossem comuns se davam por diferentes motivos. Nos conflitos entre famílias proprietárias de terras a violência era utilizada de modo recorrente, no entanto as razões nem sempre eram de natureza política ou econômica, muitas vezes os ódios eram resultantes das tradições familiares, das honras ofendidas, e da necessidade social dos machos se imporem. 
Mas, os dois principais motivos eram certamente a política e a honra das famílias. Os macieis da cidade de Quixeramobim e os araújos de Boa Viagem viviam em guerra; assim como os feitosas e os montes no Ceará ou os militões e os guerreiros na Bahia. Um acontecimento importante veio agravar os conflitos entre araújos e macieis. Começou quando Luciano Domingues de Araújo acertou casamento com dona Joana, filha legítima de Inácio Lopes Barreira, pertencente à família Queiroz que tinha parentesco com os macieis. Miguel Carlos Maciel se ofendeu com essa futura aliança que afrontava, no seu entender, os seus brios e procurou evitá-la por todos os meios.

Miguel Carlos Maciel não conseguindo, porém, evitar o matrimônio mandou matar ao noivo, para não vê-lo entrar na família, encarregando do assassinato Estácio José da Gama, agregado do seu irmão Antonio Maciel, ao qual entregou uma faca de ponta e um bacamarte já carregado. Na véspera do casamento, José da Gama, ficou de tocaia, por detrás de uns paus, num lugar chamado Cachoeira, por onde devia necessariamente passar Luciano com sua comitiva. Assim aconteceu, de tal sorte que, quando chegou à vez do noivo passar, um tiro certeiro e fatal o derrubou do cavalo. Isso se deu no dia 12 de fevereiro de 1834, por volta de meio dia, aproximadamente a uma légua e meia de distância da casa da noiva, em Tapuiará, para onde a comitiva se apressou, porque estava conduzindo o convalescente ensangüentado em uma rede. Luciano, ao chegar à fazenda do futuro sogro, ainda pôde se casar, mal conseguindo se manter sentado durante o ato, instituindo em seguida a sua esposa por sua universal herdeira.

Momentos depois a família Queiroz se debruçou sobre seu cadáver e indignada jurou se vingar daquele traiçoeiro assassinato. O corpo de Luciano Domingues de Araújo foi transportado para a vila no outro dia pela manhã. O juiz de paz, após proceder ao exame cadavérico, concluiu que a vítima havia sido morta com 
tiros de espingarda granadeira. $\mathrm{O}$ assassino foi preso no dia 8 de março, processado pelo juiz de paz e submetido a interrogatório, no qual foram ouvidos os depoimentos das testemunhas. Após ser submetido ao Conselho de Jurados, Estácio José da Gama recebeu o veredicto de culpado. Com isso, o escrivão José Joaquim da Silva Lobo se dirigiu à cadeia para formular um termo de prisão. Encontrou o preso sentado em um pequeno banco, encostado a uma grade com algemas de campanha nos braços e grilhões nas pernas. Vestia-se com camisa de chita azul e calça branca de linho. $\mathrm{Na}$ presença de testemunhas, fizeram-se as perguntas rotineiras para aquele tipo de termo. Ele respondeu que tinha 22 anos, que era solteiro e não tinha ordens menores ou sacras. Confessou o mais importante, que tinha matado Luciano Domingues de Araújo a mando de Miguel Carlos Maciel.

O escrivão observou que o condenado tinha o cabelo em boa altura e bastante crespo e reto, olhos vivos, sobrancelhas finas e arqueadas, nariz proporcionado, algum tanto grosso, orelhas pequenas, boca pequena e lábios finos, sem barba, rosto redondo, de baixa estatura e corpulento. Ao se aproximar da hora da execução o fúnebre cortejo saiu da prisão. Na frente ia o porteiro da cadeia Manoel Gomes da Silva apregoando a sentença em voz alta. Seguia-lhe o juiz de direito interino, capitão Antonio Duarte de Queiroz e a direita o escrivão Lobo. O réprobo se mostrava resignado, tendo ao seu lado como confessor da agonia o padre Bento Antonio Fernandes, vigário da Freguesia. A força pública era composta de 10 praças, comandada pelo cabo Estanislau Paes Barreto. Todos caminhavam ao som dos sinos que dobravam incessantemente a finados. Era nesse clima tenso e pungente que os réus, condenados a pena capital, seguiam em direção ao seu último destino na terra cearense.

A comitiva percorreu algumas ruas até que entrou na matriz, onde se 
mostrou ao condenado à sepultura que esperava seu cadáver, mais a enxada e a pá com que tinha sido aberta. Esse procedimento variava de uma localidade para outra e sua morbidez se devia ao tamanho dos ódios envolvidos. Seguiu-se em direção à Praça de Santo Antonio, lugar do suplício. Aí estavam fincadas duas forquilhas, na distância de dez palmos uma da outra, entre as quais foi colocada uma cadeira de madeira, em que se sentou o paciente. Suas mãos foram atadas nos varões e nesta triste posição chegou a falar ao povo. Disse que lamentava morrer por ter assassinado apenas uma pessoa, enquanto entre os 10 que iam lhe tirar a vida havia um que já tinha cometido 8 assassinatos. E dirigindo-se à tropa pediu "Meus amigos, só lhes peço que não me deixem sofrer". ${ }^{36}$ Quando o padre chegou ás ultimas palavras do credo - vida eterna... Fez-se ouvir uma descarga de cinco tiros, que não o mataram logo, mas uma segunda acabou de matá-lo. Nesse dia todas as casas se fecharam, e o pranto era copioso e geral. ${ }^{37}$

Paulino Nogueira considerou que a execução de Estácio foi ilegal e ocorreu porque ele não tinha proteção, fortuna ou parentela. Contudo, após o fuzilamento, a lei, a justiça e a própria família Araújo ficaram satisfeitas em Quixeramobim. Quanto a Miguel Carlos Maciel, acusado de ser o mandante, nada lhe aconteceu. E mais uma vez a corda se quebrou do lado mais fraco. ${ }^{38}$ A violência, assim como a seca, afetava com mais intensidade os mais pobres e miseráveis que não tinham quem lhes dessem proteção. No Ceará a corda arrebentou do lado mais fraco várias outras vezes.

Um outro caso de aplicação da pena capital ocorreu na Serra do Estevão, termo de Quixeramobim, onde residia um português chamado José de Azevedo, mais conhecido por José de Fama (de fama ruim provavelmente), casado com uma mulher

\footnotetext{
${ }^{36}$ NOGUEIRA, Paulino. Op. cit, p. 169.

${ }^{37} \mathrm{Ibid}$.

${ }^{38}$ Ibid, p. 172 .
} 
chamada Joaquina, tida como de maus costumes. Essa mulher se amasiou com o escravo José, um mulato ladino que depois se tornou conhecido pelo apelido de Fuisset e, de acordo com ele, resolveu matar, em conluio com a sua amante, o incauto lusitano. Eles combinaram que o escravo convidaria seu senhor para ir ao mato comer uma gorda colméia de abelhas jandaíra e nessa ocasião iriam executar o seu crime.

Assim aconteceu: quando José da Fama se entretinha saboreando uns favos de mel, o escravo lhe deu traiçoeiramente uma machadada na nuca com tanta força que o lançou por terra, já quase morto, e voltou logo a anunciar a adúltera o acontecido. Mas, esta não acreditando na morte quis se certificar com os seus próprios olhos. Efetivamente encontrou o marido já muito inchado, mas ainda vivo pedindo-lhe de mão postas para que não o matasse. Ela ao contrário mandou que o amásio o acabasse de vindimar, e como não fosse obedecida, com suas próprias mãos acabou de trucidar o marido e jogar o seu cadáver em meio a umas pedras, cobrindoo com ramos, supondo assim que este não pudesse ser encontrado. Dispostas assim as coisas, os assassinos voltaram para casa, seguros da impunidade. Mas, enquanto o cadáver do infeliz homem era abandonado pelo seu servo e pela sua esposa; sua cachorrinha, não saiu do seu lado latindo freneticamente.

Os latidos pungentes e incessantes da cadelinha chamaram a atenção dos viajantes e caçadores, descobrindo-se assim o crime e os seus delinqüentes. Estes foram denunciados e perseguidos. O escravo se refugiou na Serra do Machado onde foi preso, mas a mulher se valeu da proteção do régulo Gonçalo Nunes Leitão, a cuja sombra viveu por vários anos, sendo incerto o destino que depois veio a ter. Já o escravo, como era de se esperar, não teve a mesma sorte e foi condenado à morte pelo júri de Quixeramobim. Nessa época vigorava uma lei de 10 de junho de 1835 
que dizia que o escravo que matasse seu senhor seria executado sem apelo ou agravo.

${ }^{39}$ Algum tempo depois as execuções tiveram que ter a audiência prévia do presidente da província.

No entanto, àquela época a execução de Fuisset não teve esse trâmite, ocorrendo às 4 horas da tarde, em 30 de março de 1837, no Alto do Rosário, onde se levantou uma forca. Mas, o garroteamento quase foi adiado por falta de um carrasco. Até as vésperas da execução do apenado não havia um condenado ou quem quisesse prestar-se a tão odioso ofício, muitos por medo de que essa prática se tornasse recorrente e eles próprios pudessem vir a serem vítimas dela. Um outro motivo era que as penas de mortes eram pouco significativas em termos gerais em relação ao cômputo das prisões, no entanto seu efeito era exemplar no tocante à manutenção das hierarquias causando entre os pobres, verdadeiro horror e consternação.

Diante da premente falta de candidatos a carrasco o juiz da execução, o tenente-coronel Pedro Jaime de Alencar Araripe, foi à cadeia que estava cheia de recrutas para o exército e ofereceu soltura imediata àquele que quisesse se prestar a tarefa de algoz do mulato Fuisset. Logo se apresentou um, recebendo como pagamento a soltura prometida, 5 mil réis, mais uma garrafa de vinho e uma galinha gorda. O réu durante os momentos de agonia se mostrou abatido recusando a alimentação que lhe ofereciam. Fizeram-no percorrer algumas ruas da vila ao som do dobrar pungente dos sinos. O acompanhava além do seu confessor da última hora, o vigário interino padre Inácio Antonio - que em todo o trajeto recitava o salmo 50 de Davi.

Enquanto isso, o porteiro Manoel Gomes - alcunhado de Grazina pronunciava a sentença. Todos os senhores de escravos mandaram que seus cativos fossem assistir o ato. Mas uma circunstância especial modificou as cores daquele ${ }^{39}$ Ibid, p. 175. 
quadro. Até aquele dia não havia caído ainda uma gota de água do céu, de forma que todos contavam com uma seca iminente. Mas, antes de terminar a execução, de repente o céu escureceu e caiu uma chuva torrencial e duradoura, que dispersou a atenta platéia na direção dos seus domicílios, deixando ainda dependurado o cadáver do escravo, que somente no outro dia de manhã foi finalmente sepultado. Logo esse episódio se tornou parte da crendice popular, que tomou o fato como algo de caráter de castigo de Deus, e como certa a salvação do réu, para quem se começou a fazer promessas e pedidos, alçando-o da categoria de fornicador para a de santo. Os escravos que foram assistir a execução, obrigados pelos seus senhores, provavelmente eram solidários a Fuisset e bastou-lhes uma chuva repentina para despertar-lhe a comoção e o lamento.

Os jurados também foram acometidos pela emoção e juraram nunca mais condenarem ninguém a morte no Ceará e o juiz a não presidir a mais nenhuma execução. Fuisset passou a ser a imagem de Cristo crucificado e, os seus algozes, judeus arrependidos. Entretanto, esse fato aparentemente miraculoso era natural, comum e geral no Ceará, pois as chuvas naquela terra se precipitam e se dissipam repentinamente. Quase ao mesmo tempo, com a diferença de apenas algumas horas depois, a mesma chuva caiu em toda a Província, inclusive na capital cearense, dispensando uma grande procissão de penitência, que andava pelas ruas, á noite, suplicando aos céus a revogação do castigo, que se reputava iminente - a seca.

No Ceará, na primeira parte do século XIX os crimes de sangue eram punidos com a pena de morte e foram condenadas na província 41 pessoas: 39 homens e 2 mulheres. Esses indivíduos foram condenados sob diferentes regimes jurídicos como as ordenações do reino, a comissão matuta, a comissão militar, pelo júri ou no domínio do código criminal. Desses foram executados 37 (26 por 
enforcamento e 11 por fuzilamento). Quanto à condição jurídica 21 eram livres e 16 eram escravos. A maior parte desse rol era de homens pobres, mas também podemos incluir padres, coronéis, tenentes-coronéis e até 1 major. A maioria das execuções ocorria na capital, mas também houve em outros locais como Sobral, Icó, Quixeramobim, Crato, Aracati, Ipú, Viçosa, Granja, São Mateus e São Bernardo. ${ }^{40}$

Esses números são indícios do estado de violência em relação à sociedade. O próprio governo cometia excessos de autoritarismos tratando o povo pelo sistema do cacete, como já se dissera acerca da gestão alencarina. A violência praticada pelos sertanejos se coadunava com a conjuntura política, econômica e social de exclusão e dominação do homem pobre e livre mediada pelos próprios governos. Assim, a forma autoritária e virulenta com que as elites proprietárias tratavam a população levava ao recurso da força através do punhal e do bacamarte. $\mathrm{O}$ professor Ximenes Aragão relatando suas memórias sobre a seca de 1824-1825 destacou que havia um uso excessivo da violência policial contra as famílias, pois bastava polícia saber que qualquer indivíduo tinha a menor desavença com a sua esposa para ser logo pegado e metido na chibata ou ir ver o Monte Vidéo. Seria um relato sem fim se o professor Aragão se propusesse a narrar fatos de semelhante natureza. Todas as crueldades contra os sertanejos se praticavam no meio da calamitosa fome, que devorava o infeliz povo. ${ }^{41}$

No sertão a violência era um componente agravante do cenário de ódio, rancor e ressentimento entre capazes, policiais, representantes do governo, fazendeiros e juízes. A violência permeava os mais recônditos lugares e pessoas, como os chefes de famílias, os maridos e os irmãos que precisavam usar da força e das próprias relações familiares para se defenderem de diversos ataques aos

\footnotetext{
${ }^{40}$ Ibid, p. 325.

${ }^{41}$ FROTA, D. José Tupinambá da. História de Sobral. 2a ed. Fortaleza: Editora Henriqueta Galeno, 1974 , p. 426.
} 
domicílios, à honra das mulheres e a si mesmos. Dizia-se haver em Sobral, um homem a quem davam o nome de cirurgião. Era João José Ferreira que ia tomar o pulso ao padecente, agredido pela força policial. Este debruçado sobre a granadeira ouvia do cirurgião que ainda agüentava tantas chibatadas quando ele às vezes não durava mais alguns minutos. ${ }^{42}$

Existia por parte do estado, um uso exagerado da violência, de modo que os conflitos pessoais que envolviam marido e mulher, pais e filhos ou vizinhos eram resolvidos, muitas vezes, sem que se abrisse processo criminal. Por meio de ritos sumários se julgava culpado a muitos inocentes e duros castigos lhes eram aplicados. Pode-se dizer que a violência era o campo de diálogo por excelência que permeava o comportamento de toda uma população em razão da existência de uma teia de poder que tinha por base a propriedade da terra e subjugava agregados e empregados das fazendas, alçados a categoria quase de fâmulos. A consolidação do estado Nacional dependeu da sufocação das Revoltas Regenciais de 1831 a 1840. Depois disso, as elites do Império compreenderam que havia uma associação direta entre revoltas políticas e violência local.

\section{2.- O Ministério Eusébio envia o presidente Silveira da Motta.}

O partido Conservador voltou ao poder depois de 1837 e após 1840 encetou o combate à violência no Brasil. A questão da segurança pública se deu em razão das revoltas regenciais e como uma preocupação com a segurança da própria monarquia. A Violência se tornou uma calamidade política, pois no período regencial houve a mobilização líderes populares, sendo considerada, por Francisco Iglésias, como a "fase mais rica da história do Brasil como manifestação popular e tomada de

${ }^{42}$ Ibid, p.426. 
consciência". ${ }^{43}$ A prova disso eram os "nomes plebeus dos movimentos: cabanos, balaios, farrapos, característicos de rebeldia primitiva". ${ }^{44}$ Com a Lei de Interpretação do Ato Adicional, votada em maio de 1840 teve início o regresso, ou seja, um retorno à tendência centralizadora da administração central. A lei retirou várias atribuições das províncias, fortaleceu o papel do imperador e bloqueou as iniciativas democratizantes do período anterior. Segundo Raymundo Faoro “os capangas dos senhores territoriais passaram a ser capangas do império, conduzidos pelos presidentes de províncias e seus agentes". ${ }^{45}$

Entre os líderes da retomada conservadora estava Eusébio de Queiroz que fundou o partido Conservador, chefiou a polícia da Corte durante onze anos e é de sua autoria leis e medidas importantes como a Lei de Terras, a criação do Código Comercial e lei que levou o seu nome (Euzébio) proibindo o tráfico de escravos. Durante o gabinete do Visconde de Olinda Euzébio foi Ministro da Justiça juntamente com Paulino José Soares de Souza (Ministro dos Negócios Estrangeiros) e Rodrigues Torres (Ministro da Fazenda) formando a chamada "trindade saquarema", grupo responsável pela hegemonia conservadora que por longo tempo marcou a política imperial e pela repressão a revolta Liberal de $1842 .{ }^{46}$ Por causa do tempo em que ficou a frente da direção da polícia, de sua posição política privilegiada e das medidas que implementou, "Euzébio de Queiroz é considerado a figura mais destacada da polícia da Corte em todo o século XIX”. ${ }^{47}$

Quando no comando da polícia da Corte realizou visitas periódicas às prisões, para detectar possíveis irregularidades, mandou reconstruir o pelourinho da

${ }^{43}$ IGLÉSIAS, Francisco. História Geral do Brasil. São Paulo: Ática, 1989, p.161.

${ }^{44}$ Ibid., p.161.

${ }^{45}$ FAORO, Raimundo. Os donos do poder: formação do patronato político brasileiro. Vol. 1, $2^{\text {a }}$ ED. Porto Alegre, 1958, p.333.

${ }^{46}$ MATTOS, Ilmar R. O tempo de Saquarema. A formação do estado Imperial. São Paulo: Hucitec, 1990, p.105.

47 VAINFAS, Ronaldo (org.). Dicionário do Brasil Imperial (1822-1889). Rio de Janeiro: Objetiva, 2002, p.246. 
cidade (extinto em 1830) e inaugurou uma Casa de Correção aos moldes das americanas e européias. De acordo com Carlos Eugênio Líbano Soares, teria sido o primeiro a perceber a importância da política de informações para debelar estratégias escravas e para controlar a população livre e liberta de origem africana nas cidades. 48 Sua proposição de uma lei extinguindo o tráfico de escravos se baseava na preocupação com o crescimento populacional desse contingente, que envolvido em revoltas poderia ameaçar a própria construção do estado Nacional.

Por isso, depois das revoltas e agitações do Período Regencial teve início, durante o Segundo Reinado, o processo de recentralização político-administrativo iniciado por D. Pedro II com a Lei de Interpretação de 1840 e um ano depois o governo imperial reinstituiu o Conselho de Estado. Quando Euzébio de Queiroz assumiu a pasta de ministro da Justiça se começou a exercer maior fiscalização sobre as administrações provinciais. Para isso, determinou por meio de um aviso de 1848 que todo presidente fizesse e apresentasse um relatório no final da sua gestão. Por causa dessa medida ficamos sabendo o que disse o antecessor de Silveira da Motta ao passar-lhe a administração da província. Segundo ele os crimes de homicídios, roubos, e furtos cometidos na província o assustavam e desanimavam, "porque sendo aqui nascido e criado, não tinha lembrança de que em época alguma, mesmo depois da seca de 1825 , tivesse a mesma província da infelicidade de achar-se no estado em que a via". 49

A política de segurança pública iniciada pelo ministério Eusébio demorou pouco até surtir os primeiros efeitos. Em 1849 obs ervou o mesmo presidente J. M. da Silva Bittencourt que não era nada lisonjeiro o quadro que ele tinha de apresentar a

\footnotetext{
${ }^{48}$ SOARES, Carlos Eugênio Líbano. A Capoeira escrava e outras tradições rebeldes no Rio de Janeiro (1808-1850). Campinas, Unicamp, 2001, p.32.

49 APEC - Relatório do presidente da província do Ceará Ignácio Francisco Silveira da Motta. Tipografia Cearense, 1851, p.4.
} 
Assembléia e ao ministério sobre a segurança pessoal e de propriedade. O motivo disso era que nos sertões da província os direitos individuais ainda não eram uma das garantias da civilização, porque o bacamarte continuava a ser um recurso adotado para a reparação e a vingança de ofensas particulares. Por outro lado, o latrocínio se tornava o meio ordinário de subsistência das classes proletárias da província. Estes eram segundo ele, males inveterados, que para serem extirpados levariam tempo até que os poderes sociais estudassem as causa que os produziam, "e procurassem removê-los, despendendo todos os meios adequados". ${ }^{50}$

Ainda em 1850 o mesmo presidente anunciava pesaroso perante a Assembléia Provincial que ainda se repetiam os atentados contra a segurança pessoal e da propriedade, principalmente nos sertões da província. Ele preveniu os deputados que o mapa das condenações (49 réus, sendo 18 por homicídios), proferidas pelos tribunais, apresentava uma cifra muito inferior ao número dos crimes cometidos, porque a maior parte dos criminosos ficava impunes. Isso acontecia devido à facilidade com que muitos bandidos escapavam à ação das autoridades e a incompreensível indulgência que caracterizava, na sua maior parte, as decisões dos júris. Nos quadros da estatística criminal da província figuravam sempre em pequena escala os crimes contra a propriedade. Porém, que, limitando-se na província os atentados deste gênero quase exclusivamente ao furto de gados, mal comum a todas as províncias criadoras; e não cabendo pela legislação a acusação oficial da justiça em crimes desta categoria, poucas vezes eram levados a julgamento os seus perpetradores; porque as partes lesadas, não confiavam na severidade dos tribunais, e por isso receavam comprometer-se e fazer despesas inúteis. ${ }^{51}$

Após vários episódios de ódios e execuções foi enviado direto da Corte

\footnotetext{
${ }^{50}$ GABAGLIA, Giácomo Raja. Op. cit., p.108.

${ }^{51}$ Ibid., p. 109.
} 
para governar o Ceará durante o Ministério Eusébio, Francisco Inácio Silveira da Motta com a tarefa de combater aos criminosos que fragilizavam a segurança individual e da propriedade no sertão. Aspecto que vinha solapando as bases da governabilidade, pois os potentados rurais compunham um poder dentro de outro como observou em suas memórias Pedro Theberge. De acordo com ele, a família Feitosa era conhecida pelas desavenças com a família Monte e acoitava "todos os criminosos que iam implorar a sua proteção. Formando assim um estado independente no estado". ${ }^{52} \mathrm{O}$ povo cearense, por isso teria apoiado as medidas tomadas por aquele presidente, guardando dele boa recordação. No entanto, isso somente foi possível devido ao fato de que poucas vezes a Assembléia Legislativa Provincial se reuniu e Motta por isso não encontrou óbices à aplicação das suas medidas.

Silveira da Motta, futuro barão de Vila Franca, assumiu a presidência da província de novembro de 1850 a junho de 1851. Durante sua administração despendeu recursos públicos na construção e reparos das cadeias porque o estado da segurança individual e da propriedade privada absorveu sua atenção, pois a violência era o principal problema. Porém, desde então a repressão à criminalidade se tornou a tônica dos governos cearenses até 1877. Ao deixar a presidência da província Silveira da Motta declarou ao seu sucessor Joaquim Marcos de Almeida Rego que a província estava sendo moralizada pela prisão e processo de criminosos, muitos dos quais eram protegidos por potentados rurais.

Com isso, ficava-lhe aberta a possibilidade para continuar o processo de combate a criminalidade, sem tropeços, continuando não só a desinfestá-la da presença dos malfeitores, como também a destruir os asilos em que estes se

\footnotetext{
52 THEBERGE, Pedro. Esboço Histórico sobre a Província do Ceará. Fortaleza: Fundação Waldemar Alcântara, 2001, p.242.
} 
abrigavam. ${ }^{53}$ Como observou Cruz Abreu, a proteção aos facínoras se dava porque havia no Ceará da parte dos políticos militantes de um e de outro partido, proteção manifesta a certos chefes locais, cujo prestígio provinha não tanto de sua favorável situação econômica, mas do número de sequazes empregados ao seu serviço. ${ }^{54}$

No Ceará havia régulos que dominavam o sertão da maneira mais absoluta. Existia uma rede de parentela e compadrio, por meio da qual, fazia-se efetivo o exercício do poder. Entretanto, quando o Ministério Euzébio ascendeu ao governo do país recomendou aos presidentes das províncias que empregassem todos os seus cuidados na perseguição incessante dos criminosos, que infestavam toda a superfície da província. ${ }^{55} \mathrm{O}$ novo administrador - Silveira da Motta - empregou, segundo Pedro Theberge, energicamente todas as suas forças no sentido de reprimir os criminosos, capturá-los e submetê-los aos tribunais, a despeito da proteção desse ou daquele potentado. ${ }^{56}$ Uma das dificuldades para que esse presidente tivesse êxito no combate ao crime residia no fato que vigia no Ceará o direito privado sobre o público, o que envolvia o povo numa interminável onda de violentas revanches. Mas, ao fazer preponderar a justiça do estado, Motta conseguiu frear o ímpeto das vinganças pessoais, satisfazendo em parte as honras ofendidas.

Para isso, ele passou a nomear como empregado de polícia quem executava capturas, mas como nem sempre ficava satisfeito com os resultados apresentados tomou o expediente de nomear delegados os oficiais comandantes dos destacamentos, medidas estas que nem sempre eram muito convenientes, mas que nas condições excepcionais como as enfrentadas pela província naquela época

\footnotetext{
53 APEC - Relatório de Ignácio Francisco Silveira da Motta. Tipografia cearense: Rua da Boa vista ${ }^{\circ}$. 33, 1851, p. 04.

54 ABREU, Cruz. Presidentes do Ceará. Revista do Instituto Histórico e Geográfico do Ceará. Ano XXXVIII, 1924, p. 127.

55 THEBERGE, Pedro. Op. cit., p. 242.

${ }^{56}$ Ibid., p. 245.
} 
surtiram bons resultados. Foi com este modo de proceder que se deu um passo importante na repressão aos crimes; e, como os presidentes ulteriores porfiaram em seguir o impulso dado, em breve viu-se como mudou "inteiramente de face o estado do Ceará". 57

Silveira da Motta utilizou diversos estratagemas para fazer cessar os conflitos entre as famílias poderosas do Ceará, mormente as da cidade do Ipú, para onde enviou até frades capuchinhos. Ele compreendeu que seria muito conveniente que, penetrando no Ceará, aqueles religiosos começassem suas missões por aquele termo do Ipú, “onde os ódios profundos de famílias sanguinárias tantas vítimas haviam feito", tornado o "município de Inhamuns, celebre pelas atrocidades e crimes ali cometidos". ${ }^{58}$ Os frades capuchinhos tinham a missão de apaziguar os ânimos das famílias em guerra, pois se a força e a ameaça de prisão não resolviam era hora de apostar na religiosidade dos sertanejos como meio de amainar os ânimos. Essa estratégia era a mesma utilizada pelos sesmeiros e capitães-mores, no início da colonização portuguesa, para arrefecer o ímpeto guerreiro das tribos que lhes eram hostis.

Já no que tangia a segurança direta, Silveira da Motta promoveu o recrutamento para a polícia, pois era necessário formar e ampliar os contingentes. Cruz Abreu observou como o recrutamento insidia diretamente sobre a família, desintegrando-a, produzindo viúvas e órfãos. Esse esforço policial levou ao cometimento de vários abusos por parte de algumas autoridades. Os recrutadores de Motta cometiam exageros, como noticiou o jornal Cearense acerca de um episódio doloroso: o espetáculo de 22 miseráveis, cobertos de andrajos imundos, carregados de ferro, como se fossem galés, arrancados ás suas mulheres, filhos e pais, para

\footnotetext{
${ }^{57}$ Ibid., p. 244.

58 ABREU, Cruz. Presidentes do Ceará. Revista do Instituto Histórico e Geográfico do Ceará. Ano XXXVIII, 1924, p.156.
} 
encher os quadros do exército do Brasil.

Nesse tempo eles iriam alvejar com suas ossadas os inóspitos campos do Rio Grande do sul, ${ }^{59}$ onde enfrentariam as tropas comandadas por Bento Gonçalves. Nessa época, ainda estava em curso a Guerra dos Farrapos, movimento que começou com a revolta contra a política tributária do Governo Central, que facilitava a entrada da carne bovina da Argentina, prejudicando o comércio do charque produzido no Sul e contra a indicação do presidente da província.

Apesar dos excessos, Silveira da Motta não cessou, no entanto, até o final de sua gestão, a perseguição aos facínoras acoitados no Ceará, afugentando por isso numerosos homiziados no território. Prosseguindo com empenho, encheu as cadeias de criminosos, que foram julgados por feitos recentes e antigos. ${ }^{60}$ Durou pouco a sua presidência, durante a qual não houve nem eleições, nem reunião da assembléia provincial, por isso ele teve a sorte de concluí-la sem desagradar á nenhum dos partidos. Retirou-se bem quisto e abençoado por todos; o que, sem dúvida, não teria durado muito tempo porque perseguiu os criminosos até dentro dos asilos dos prepotentes, que já se mostravam insatisfeitos com ele; mas o povo que gostava de ver posta em prática a igualdade das pessoas perante a lei, conservou dele uma lembrança que durante longo tempo subsistiu. ${ }^{61}$ Apesar de sua ótima administração, Silveira da Motta recusou em 1860 qualquer candidatura pelo Ceará por temer a oposição do chefe conservador Miguel Fernandes Vieira. Como observou Richard Graham as eleições ao disseminarem violência e dissensões "poderiam destampar um vulcão". ${ }^{62}$

\footnotetext{
${ }^{59}$ Ibid., p. 162.

${ }^{60}$ Ibid.

${ }^{61}$ APEC - Relatório do presidente da província do Ceará Ignácio Francisco Silveira da Motta. Ceará: tipografia cearense, Rua da Boa vista ${ }^{\circ}$. 33, 1851, p. 245.

${ }^{62}$ GRAHAM, Richard. Clientelismo e política no Brasil do século XIX. Rio de Janeiro: Editora UFRJ, 1997, p.104.
} 
Para o Imperador D. Pedro II as eleições deveriam transcorrer de maneira organizada e sob os auspícios da lei. Na opinião do rei se as eleições ocorressem como deveriam o Brasil teria futuro certo "e o monarca dias serenos...". ${ }^{63}$ As turbulências nos processos eleitorais eram uma ameaça à governabilidade, pois criava instabilidades à monarquia constitucional. Nesse sentido, D. Pedro II compreendia que a principal necessidade política do país era "a liberdade de eleição". ${ }^{64}$ De fato, esse problema perpassou a realidade social brasileira durante todo o seu reinado. Nos mais distantes rincões o voto era controlado pelos coronéis e houve, pode-se dizer que até o fim da Primeira República uma dicotomia entre o poder central e o poder local. O povo pobre ficava na berlinda entre o que pretendia o rei distante e o coronel que lhe fornecia abrigo, trabalho e proteção.

Silveira da Motta ao terminar a sua gestão, assegurou ao seu sucessor que não havia passado 8 meses desde que ele começou a combater a violência na província que fragilizava o estado da segurança individual e da propriedade, "e já a província se acha moralizada com a prisão e protestos de muitos importantes criminosos, que a infestavam". ${ }^{65}$ Justificou-se ao seu sucessor e a Assembléia Legislativa que o estado da segurança individual e de propriedade absorveu quase toda a sua atenção, e por isso descuidou de "muitos melhoramentos reclamados em diferentes ramos do serviço". ${ }^{66}$ Apesar do descuido de outros serviços a violência e as guerras entre famílias requeriam maior cuidado e atenção, por isso Silveira da Mota saiu satisfeito porque o direito a vida e a propriedade se achavam mais garantidos que "em algumas épocas anteriores". ${ }^{67}$

\footnotetext{
${ }^{63}$ MOSSÉ, Claude. Atenas: História de uma Democracia. Universidade de Brasília, 1979, p.24.

${ }^{64}$ Ibid, p. 24.

${ }^{65}$ APEC - Relatório do presidente da província do Ceará Ignácio Francisco Silveira da Motta. Ceará: tipografia cearense, Rua da Boa vista ${ }^{\circ}$. 33, 185. Op. cit, p. 4.

${ }^{66}$ APEC - Relatório do presidente da província do Ceará Ignácio Francisco Silveira da Motta. Tipografia cearense, Rua da Boa vista n ${ }^{\circ}$. 33, 1851, p. 4.

${ }^{67}$ Ibid.
} 
A preocupação com os episódios de violência no sertão não desapareceu com a saída de Silveira da Mota. Em 1853 o presidente Marcos da Silva Rego compreendia que a maior parte dos esforços da administração devia recair sobre o combate a violência, pois a "falta da segurança individual e da propriedade é o grande inconveniente, com que, há muito, luta a província". ${ }^{68}$ Isso era visto não apenas como uma deficiência do processo civilizatório da população, mas, sobretudo uma ameaça à estabilidade política da monarquia. $\mathrm{O}$ rei desejava continuidade no enfrentamento da criminalidade e por isso, o principal intento dessa administração foi dar "incremento à tarefa encetada pelo meu antecessor". ${ }^{69}$ Giácomo Gabaglia observou que em 1852 surgiram os primeiros indícios de melhoramento "na administração do presidente Almeida Rego, que presta o importante serviço de nesse ano fazer captura 193 criminosos". ${ }^{70}$ Porém, esse melhoramento começou com Silveira da Motta e não com Marcos da Silva Rego.

O presidente da província em 1853, Joaquim Vilela de Castro Tavares, apresentou os números da segurança pública de maneira entusiasmada ao constatar que 193 bandidos foram capturados no curto prazo de 13 meses e que do final de 1852 até 1853 foram presos 53. Segundo ele, era necessário considerar que este número era excessivo, “atentas às circunstâncias anteriores da província, cuja recuperação no que tangia a violência, destacou ele data de poucos anos". ${ }^{71}$ Por isso a situação da província no que tange a segurança pública estava ficando lisonjeira. Em 1854 o presidente Pires da Motta constatou que os crimes contra a segurança individual superavam os crimes contra a propriedade e um ano depois ele afirmou

\footnotetext{
68 Ibid.

69 APEC - Relatório do presidente da província do Ceará Joaquim Marcos de Almeida Rego. Tipografia Cearense 1853, p.3.

${ }^{70}$ GABAGLIA, Giácomo Raja. Op. cit. p.109.

71 APEC - Relatório do presidente da província Joaquim Marcos de Almeida. Tipografia Cearense, 1853 , p.3-4.
} 
que "Não se violenta a verdade declarando que o Ceará, proporcionalmente a sua população, é das províncias onde menos crimes se cometem". ${ }^{72}$ Gabaglia observou que "Desta data em diante há leves modificações na linguagem oficial e vê-se que o estado das massas tende a melhorar do ponto da estatística criminal". 73

Em 1860 houve um violento conflito entre liberais e conservadores na Vila da Telha por causa da eleição para vereadores e juízes de Paz, na qual a faca de ponta e o bacamarte foram chamados à mesa de negociação. O senador Pompeu reclamou ao Sinimbú da atuação do presidente da Província Antonio Marcelino Nunes Gonçalves. O senador Sinimbú lamenta o acontecido na vila de Telha (hoje Iguatú), dizendo não poder "deixar de lastimar que de tanta excitação se tenham deixado apoderar os ânimos em alguns lugares dessa província, que cheguem aos excessos de que foi teatro a vila aquela Vila". Entretanto, diante das queixas de Pompeu, ele demonstrou discordância por considerá-las injustas, pois por "suas comunicações oficiais vê-se que ele compreende perfeitamente a situação da Província, que sinceramente deseja melhorá-la". ${ }^{74} \mathrm{O}$ problema da violência eleitoral não era local, pois o uso da violência entre liberais e conservadores poderia criar precedente para a luta política e uma ameaça estabilidade monárquica. Por isso, embora Sinimbú tivesse grande estima por Pompeu não consentiu nas críticas ao presidente Marcelino.

Na opinião de Sinimbú era difícil conter a violência eleitoral no Ceará porque quando as coisas chegavam à situação de um partido para triunfar sobre outro, destituir seus adversários de todas as garantias, recorrendo-se aos meios mais

\footnotetext{
72 APEC - Relatório do presidente da província do Ceará Ignácio Francisco Silveira da Motta Tipografia cearense, Rua da Boa vista $\mathrm{n}^{\circ} .33,1851$, p. 4.

73 GABAGLIA, Giácomo Raja. Op. cit., p.111.

${ }^{74}$ CAMARA, José Aurélio Saraiva (org.). Carta de J.L.V. Cansanção de Sinimbú, Rio de Janeiro, 21 de outubro de 1860. Correspondência do Senador Pompeu. Fortaleza: Tipografia Minerva, 1960, p. 81 .
} 
violentos para se conseguir a vitória, pouco poderia fazer a autoridade do presidente no sentido de acabar com essa situação. A única forma seria intervindo diretamente no processo eleitoral, mas não lhe era permitido pelas normas ministeriais. Não obstante, não era responsabilidade do ministério naquele momento, aquela situação, pois ela era o produto de um passado que ele já encontrou. Com isso, Sinimbú procurava assegurar ao Pompeu que o presidente da Província estava dominado dos melhores desejos de levar as coisas pelo bom caminho, pois lhe disse que as "repetidas instruções que recebo do Governo imperial são todas nesse sentido". ${ }^{75}$ Ademais, o próprio Sinimbú já havia se deparado com o problema da violência quando pacificou a Província de Alagoas em 1839, promovendo a transferência da capital para Maceió.

O desembargador João Antônio de Araújo, dirigindo-se à Assembléia Legislativa do Ceará em 1870 chamou a atenção dos parlamentares para o fato de que em várias localidades distantes surgiram algumas dificuldades em decorrência de rivalidades locais, e não "nascidas de idéias políticas". ${ }^{76}$ De fato, as disputas violentas que ocorriam estavam relacionadas a diferentes motivos e o político era apenas um deles. Nem todas as famílias eram envolvidas com a política partidária cearense. Podia-se ir as vias de fato, por questões de honra que envolvia esposa e filhos, ofensas pessoais, pequenas agressões físicas, rixas antigas, etc. Nesse aspecto, o terreno da política e o da disputa e rivalidade local e individual se imbricavam. Diferentes grupos familiares se associavam e se separavam a partir de seus interesses e conveniências, tornando o enlace entre política e parentela, decisivo nas lides políticas e unindo o espaço público e o privado numa mesma dimensão social - a

\footnotetext{
75 Ibid., p.82.

76 APEC - Fala do desembargador João Antonio de Araújo Freitas. $1^{\mathrm{a}}$ sessão da $18^{\text {a }}$ legislatura da Assembléia Provincial do Ceará - Fortaleza, Tipografia Constitucional, no dia $1^{\circ}$ de setembro de 1870. p.5.
} 
violência.

Isso ocorria em razão de muitas autoridades fazerem parte de famílias envolvidas diretamente em conflitos. Por esse motivo, o presidente da província João Antônio de Araújo decidiu prevenir o cometimento de atos de violência, decorrente de pequenas intrigas e no intuito de reprimir com mais energia a prática de crimes decidiu mandar "para todos os pontos da província autoridades á elas estranhas". ${ }^{77} \mathrm{O}$ envio dessas autoridades intentava fazer julgamentos e tomar decisões isentas das redes de favores e comprometimentos das autoridades efetivas dos locais. Esse era um problema sério ao combate à violência no Ceará, pois ela ocorria com a anuência e, até com a participação, das autoridades que deveriam debelá-las.

As medidas tomadas por Silveira da Motta foram continuadas pelos seus sucessores como o primeiro vice-presidente da província Joaquim da Cunha Freire, que no ano de 1873 , relatou que na sua administração a tranqüilidade pública não sofreu alteração. Esse tipo de afirmação passou a ser comum nos relatórios apresentados pelos presidentes de província porque, em geral, eles entendiam "tranqüilidade pública" como sendo o espaço da rua, do centro da cidade em oposição ao espaço do domicílio. Nesse sentido, o termo "público" se relacionava às disputas políticas e aos ataques às vilas e cidades cometidos por bandidos.

Por isso a tranquiilidade pública se achava ameaçada em anos eleitorais e durante as incursões dos criminosos. Houve com a ascensão do gabinete Eusébio um esforço considerável em pacificar as províncias do Brasil envolvidas em revoltas contra o governo geral, sublevações e atentados eleitorais. Entretanto, se a tranqüilidade pública ia bem, o mesmo não se podia dizer a respeito da segurança individual, que ainda se achava, naquela província, como em quase todo o Império, “em um estado pouco lisonjeiro, devido, sem dúvida, á falta de recursos, de que ${ }^{77}$ Ibid. 
dispõem os países mais adiantados". ${ }^{78}$ A violência no sertão cearense tinha duas dimensões: uma política que ocorria nos momentos de eleição e envolvia potentados rurais rivais e uma cotidiana que se debruçava sobre as relações familiares, marcadas por valores morais como a defesa da honra - por parte do marido - que protegia a filha e a esposa através do exercício da força do bacamarte e da faca de ponta.

Já a segurança individual, relacionava-se aos casos de violência que envolvia famílias de agricultores em razão de disputas em defesa e garantia da honra. Por esse motivo o desembargador João Antônio de Araújo declarou que “os delitos de sangue, sinto dizer-vos, continuam em proporção muito maior do que todos os outros". ${ }^{79}$ Esses delitos faziam parte do cotidiano cearense e se relacionavam as formas encontradas pelas famílias de homens pobres e livres para organizarem e normalizarem o cotidiano no interior em relação ao domicílio, que se erigia como observou Antonio Otaviano em "sede da vida familiar, como locus sagrado da família e de seu maior bem: a honra". ${ }^{80}$

Os delitos de sangue praticados pelas famílias pobres dificilmente atentavam contra a tranqüilidade pública, pois seus atos se circunscreviam ao âmbito do domicílio e da comunidade local. Esses conflitos decorriam de normas de honra e a violência garantia certa estabilidade ao cotidiano da família cearense. Contudo, um acontecimento alterou esse cotidiano quando em 1876 foi baixada a nova lei do recrutamento $^{81}$ e as famílias ficaram sobressaltadas com a possibilidade de perderem seus membros masculinos. Foi então que ocorreu um movimento de mulheres formado por mães, esposas, filhas e irmãs que invadiram os lugares onde

\footnotetext{
${ }^{78}$ APEC - Relatório do presidente Joaquim da Cunha Freire. Tipografia constitucional: 13 de novembro de 1873, p.05.

${ }_{79}$ APEC - Fala do desembargador João Antonio de Araújo Freitas Henriques. $1^{\mathrm{a}}$ sessão da $18^{\mathrm{a}}$ legislatura da Assembléia Provincial do Ceará. Fortaleza: tipografia Constitucional no dia $1^{\circ}$ de setembro de 1870 . Op. cit.

${ }^{80}$ VIEIRA, Antonio Otaviano. Op. cit., p. XIV.

${ }^{81}$ Relatório do presidente Joaquim da Cunha Freire. Tipografia constitucional: 13 de novembro de 1873, a Francisco Teixeira de Sá. Fortaleza, 1873, p.35.
} 
funcionavam as juntas de Tamboril, União, Santa Quitéria e Acarape. No local elas dilaceraram os papéis que puderam colher nas mãos, retirando-se depois para suas casas. ${ }^{82}$ Esse movimento das mulheres ocorreu porque o recrutamento era um modo violento do estado formar suas milícias.

Contudo, em 1877 a população cearense atravessou um momento de transição marcado pelo fim da violência como problema político dominante para a emergência da seca como uma questão que predominava nas políticas públicas do estado. Essa mudança foi importante porque levou a uma reformulação do papel do estado e da organização da sociedade cearense. Assim, se a violência promovida pelos régulos do sertão tornou a família proprietária um problema de estado que mostrava a fragilidade do próprio estado, as secas afetarão sobremodo as famílias pobres, mulheres e homens de maneira igual tiveram motivos para rasgarem os documentos produzidos pelos burocratas dos socorros públicos.

Esse evento, o dilaceramento dos papéis, antecedeu à seca de 1877 quando o memorialista das secas, Rodolfo Teófilo, considerou que a seca estava declarada. Com isso o sentimento de pânico apoderou-se da população e ao anoitecer muitas famílias pobres se recolhiam as suas casas e com medo "falavam em migrar". ${ }^{83}$ A família sertaneja ao iniciar sua história migratória, nos períodos das secas, terminou sofrendo suas conseqüências posteriores decorrentes do seu esforço de readequação. A partir de 1877 a vinculação entre família e seca se tornou presente nas políticas de governo e nos discursos de observadores como o farmacêutico Rodolfo Teófilo, o deputado João Brígido e o literato Antonio Sales. Essa seca foi denominada por Teófilo de "a seca tipo", pois suas conseqüências foram marcantes

\footnotetext{
${ }^{82}$ APEC - Fala com que o Desembargador Francisco de Faria Lemos, presidente da província do Ceará abiu a $1^{\mathrm{a}}$ sessão da $23^{\mathrm{a}}$ legislatura da assembléia provincial de no dia 1167 de julho de 1878 Fortaleza, tipografia cearense, 1876. p.05.

83 THEÓPHILO, Rodolfo. História das Secas no Ceará (1878-1880). Rio de Janeiro: Imprensa Inglesa, 1922, p. 80 e 81.
} 
na história do Ceará.

No entanto, a constituição da seca como um fenômeno divisor de águas na província se deu em substituição a um parâmetro anterior que era a violência. Durante o período de 1850 a 1877 a violência no sertão promovida pelos potentados rurais absolveu as finanças do estado com investimentos em segurança, devido à ameaça aos indivíduos e a tranqüilidade pública. Contudo, a partir desse momento, com a eclosão da seca que se tornaria "grande seca", ocorreu uma importante mudança nesse cenário, quando as estiagens se tornaram a principal questão mobilizadora dos recursos estatais, tornando-se o motivo de uma crise social permanente, ou seja, uma calamidade política.

Durante a "grande seca" o abandono dos domicílios foi avassalador, quando comparado às situações anteriores. João Brígido descreveu o processo migratório para o Ceará comentando os anos da seca de 1825, 1792 e anos como 1831 e 1847, nos quais não havia secas ou elas não eram o problema principal, mas os conflitos entre família e os recrutamentos. Nesses anos, a migração envolvia famílias conhecidas e/ou abastadas. Assim, a migração para o Pará foi "lenta durante os bons anos que se seguiram àqueles de misérias e perigos extremos. Tornou-se, porém, intensíssima depois de 1877 e estendeu-se por toda a bacia do Amazonas, sendo dessa origem um terço ou mais da população dessa região". ${ }^{84}$

Nesse ano a ameaça à organização e conservação dos laços familiares de parentesco e amizade se concretizou numa dimensão maior e mais significativa que a de um simples recrutamento. O jornal o Retirante noticiou com espanto a estiagem de 1877, pois contemplou pasmo o século XIX e o ano de 1877, quando a população pobre foi lentamente trucidada num horrível cortejo de misérias, quando já não era

${ }^{84}$ CARVALHO, Jader de. Antologia de João Brígido. Fortaleza: Editora Terra de Sol, 1968, p. 520. 
uma ilusão a seca naquela desditosa província. ${ }^{85} \mathrm{Com}$ a seca ocorreu um processo de desagregação dos parentescos e da estrutura familiar baseada num sistema de honras, no qual a mulher casada e a filha eram colocadas sob a guarda do pai e do marido, pois na ausência dos mesmos a mulher poderia ser submetida a "uma série de obrigações e situações delicadas. Em outros casos, a distância do marido sujeitava a mulher à violência às quais ela deveria resistir com resignação moral." 86

A partir de 1877 as secas no Ceará afetaram a família e provocaram a desestabilização da agricultura, o reordenamento do domicílio e o esfacelamento dos sentimentos familiares. Da conjugação desses fatores emergiu um discurso de crise moral associado à família. No entanto, antes de 1877 a noção de crise e de perda de moralidade se relacionava ao estado bélico do sertão. O viajante George Gardner observou que o europeu era acostumado a viajar com relativa segurança, sem o uso de pistolas e adagas, de modo que o encontro com homens portando armas pelos caminhos cearenses dava "idéia muito desfavorável da moral desta gente". ${ }^{87}$ Contudo, após a "grande seca", o espetáculo da migração trouxe conseqüências para a moral familiar, pois, pois atingiu a honra das mulheres através da exploração sexual das moças, entregues em casamento a homens, muitos inescrupulosos, por seus pais ou parentes.

Nesse sentido, a noção de "crise moral" estava relacionada diretamente a falta de segurança nos caminhos cearenses, devido à existência de uma população armada, aspecto que evidenciava uma dificuldade inerente ao processo colonizador português marcado por um estado imperial inoperante, frente aos potentados rurais

\footnotetext{
${ }^{85}$ BPGMP - Jornal o Retirante, Fortaleza, 1 de julho de 1877, p.1.

${ }^{86}$ VIEIRA JR, Antonio Otaviano. O Cotidiano do Desvio: Defloramentos e adultérios no Ceará Colonial. Dissertação de mestrado: PUC/SP, 1997, p.105.

${ }^{87}$ GARDNER, George. Op. cit., p. 84.
} 
locais e as lutas de família. ${ }^{88}$ Não obstante, além dos conflitos entre famílias que envolviam comunidades inteiras e da insegurança que pairava nos sertões, somava-se a calamidade da seca com a província enfrentando prolongadas estiagens desde a última ocorrida no ano de 1825, no qual a falta de água e alimento levou ao perecimento de homens, animais domésticos e selvagens. ${ }^{89}$

A seca, enquanto calamidade, não era associada pelos viajantes à crise moral da população, pois ambas tinham raízes diferentes: uma o porte de armas e a outra a falta de chuvas. Um outro viajante chamado Daniel Kidder, que passou pelo Ceará no mesmo período de Gardner, primeira metade do século XIX, titubeou ante a dificuldade em dizer "qual a maior calamidade dessa região, se as inundações ou a seca", pois as chuvas "torrenciais e contínuas" prejudicavam a cultura do algodão e transbordavam os rios. Essa dualidade caracterizou o Ceará até o advento da seca de 1877.

É preciso considerar a existência de uma memória prévia sobre as secas, visto que os períodos anteriores não foram esquecidos e os seus efeitos deixaram marcas indeléveis na população cearense. Nos idos de 1875 surgiu na população do Ceará um sentimento de apreensão em relação à possibilidade de uma nova estiagem. Porém, um jornal que circulou em Sobral - Sobralense - noticiou chuvas no dia 11 do corrente pelas 6 horas da manhã, quando se precipitou sobre a cidade e vizinhanças uma chuva que embora não muito copiosa, prolongou-se até às 11 horas do dia, vindo a amenizar na população "as pavorosas apreensões" 90 em que se achava o povo de Sobral em conseqüência da crença do episódio de secas em anos terminados em " 5 ", como sucedeu nas secas de 1825 e 1845, "visto que a era atual é

\footnotetext{
${ }^{88}$ PINTO, Luis de Aguiar Costa. Op. cit.

${ }^{89}$ Ibid, p.82.

${ }^{90}$ BPGMP - Jornal Sobralense, n. 42, 14 de fevereiro de 1875, p.3.
} 
também de 5". ${ }^{91}$

Apesar de a população temer a seca, ela não se preparava para a possibilidade de enfrentá-la. Com isso, não apenas a seca, mas qualquer outro fenômeno climático provocaria uma catástrofe econômica e social devido à imprevidência da população, a inexistência de um governo que tratasse as calamidades climáticas como questão técnica. Isso pode ser observado quando analisamos o oposto das secas: as enchentes. O mesmo jornal de Sobral recebeu uma carta de um morador da povoação dos Remédios, na qual relatava que depois de tantas angústias causada pelas repetidas cheias que em grande parte inundaram a povoação, desenvolveu-se de novo o mesmo mal que há quatro anos infestava o infeliz lugar. Com isso, o povo sob os efeitos de um grande inverno infalivelmente morreria sem recursos e nos braços de uma calamidade mais impossível de se evitar. As doenças decorrentes das enchentes iam se revestindo de novas formas, recrudescendo horrivelmente. Encapsulou o autor da carta "e duvido que nos venha alguma ambulância do governo que, á son aise vai tudo desprezando para dar espaço ao servilismo das idéias políticas". ${ }^{92}$

Pestes como a varíola, o beribéri e as chamadas "febres de mau caráter" decorriam de enchentes prolongadas que atingiram o Ceará no século XIX. As reivindicações de socorros públicos por parte da população ocorreram, sobretudo, a partir da segunda metade, quando os jornais passaram a dar maior visibilidade ao problema das intempéries. Os jornais tiveram o papel dominante de tornar público o problema das estiagens e das enchentes, assim como de articular e formar uma opinião pública sobre o assunto. Nesse sentido, os diversos periódicos foram partícipes do processo de construção da seca como calamidade. Porém, até 1877 o

\footnotetext{
${ }^{91}$ Ibid.

${ }^{92}$ BPGMP - Jornal Sobralense, 13 de junho de 1875, p.2.
} 
discurso calamitoso era dirigido tanto às secas quanto as cheias.

O Sobralense na secção "a pedidos", chamava a atenção da câmara municipal de Sobral para a infeliz situação em que se encontrava a população, pedindo compaixão ao governo, pois caso contrário ela morreria a míngua se não fosse socorrida a tempo. O periódico chamava a atenção da Câmara Municipal da cidade para que promovesse a caridade por meio de socorros que fizessem minorar ou cessar os sofrimentos dos pobres desvalidos daquela infeliz população, que sofria com a peste e a fome que grassavam na região. Para o jornal além de um dever era uma ação generosa saciar a fome da população desvalida. ${ }^{93}$

O doutor Fried Ratzer, em artigo traduzido por Capistrano de Abreu comentou que às vezes durante a época das chuvas sobrevinham fatais inundações, outras vezes aparecia tão persistente a seca que a vegetação menos resistente morria toda, ficando aniquiladas as colheitas e sucumbindo o gado devido falta de água e pasto, grassando a fome geral. A memória do povo guardava, segundo ele, ainda horrorizada a lembrança dos anos de 1826, 1842, 1866, 1872, em que houve enchentes, e dos anos de 1825, 1845, 1877 a 1879, 1889, que fizeram milhares de mendigos e desfalcaram a população em um terço.

O problema da fome que atingia a população era provocado tanto pelas secas, quanto pelas enchentes. Ao passo em que as enchentes e as inundações representavam um problema, pois destruíam plantações, invadiam casas e disseminavam doenças e pestes, por outro lado também havia uma perspectiva que transformava o inverno em salvação geral da população. No entanto, quando o inverno era em demasia provocava as enchentes e as inundações. Estas também faziam parte da memória do povo do Ceará. O jornal Sobralense em 1875, dois anos antes da grande seca, noticiou a despeito da crença de que naquele ano a província ${ }^{93}$ Ibid. 
seria assolada por uma seca "o inverno se tem ostentado com tal furor, que com bastante razão o podemos equiparar aos 72 e 73". ${ }^{94}$ Essa equiparação, de acordo com o jornal seria em relação à abundância de chuvas e as inundações dos rios.

Do mesmo modo que havia um conhecimento e uma memória anterior a grande estiagem de 1877, também havia algo semelhante a respeito das enchentes. No dia 27 de março de 1875 as represas do rio Acaraú tiveram água um palmo a menos que na enchente de 1873 . O relato do jornal ia além, informava que a quarta parte da rua Virturia e algumas casas da rua velha do Rosário e da Palma foram invadidas pela enchente, bem como todas ou quase todas as casas que se achavam situadas pelas imediações de ambas as margens do rio. O rio Acaraú se tornou um problema permanente para a população ribeirinha. Em 1875 sua altura seria considerada extraordinária, o que levava o povo a supor que estavam vivendo numa quadra semelhante a ocorrida nos anos de 1872 e $1873 .^{95}$

Eram recorrentes as notícias de doenças e perdas de colheitas provocadas pelas cheias. Em 1875 noticiou o Sobralense que as enchentes tinham um efeito considerado menos prejudicial que as secas naquela localidade, pois no histórico do lugar não constava que as enchentes tivessem causado danos notáveis. Apesar disso, ela provocou naquele ano o desabrigo de todas as famílias, cujas casas foram invadidas pelas águas e os miasmas deletérios, corolário do estado de putrefação em que ficavam os vegetais e os animais mortos, espalhou-se amplamente. Após o refluxo das águas ocorria a emissão de eflúvios pestilentos que tornavam impura a atmosfera dos lugares mais atingidos pela força das chuvas. Diante desse quadro, o povo de Sobral pressagiava o recrudescimento das sezões e em conseqüência disso,

\footnotetext{
94 Ibid.

95 Ibid.
} 
muito receavam que tal prognóstico se realizasse. ${ }^{96}$

As enchentes provocavam o transbordamento das margens dos rios, prejudicando as colheitas e traziam várias doenças que afetavam a população, sobretudo as famílias que eram desalojadas de seus domicílios. A inundação de 1875 atingiu o município de Santana quando o rio Acaraú deu uma grande enchente, cujas águas assoberbaram-se quase a altura abarcada pela cheia de $1873^{97}$. Essa enchente inundou uma grande parte da vila em 1875, dando-lhe o aspecto de "uma Veneza, debaixo de uma enorme massa d'água". ${ }^{98}$ Inferimos, então que não apenas havia uma memória sobre as enchentes como também ela trazia conseqüências semelhantes às secas, atingindo vários municípios, provocando danos à lavoura e desabrigando as famílias.

A lembrança que os cearenses tinham a respeito da cheia de 1873 servia como comparação para o contexto de 1875. As conseqüências decorrentes dessas cheias eram as mesmas das secas: desalojamento das famílias, proliferação de doenças e perda das colheitas. Isso demonstra que a seca e as cheias eram fenômenos equivalentes no que tange ao seu impacto social e econômico. A população já vivia sob o signo das calamidades, pois as condições de possibilidade já estavam estabelecidas. As chuvas assim como as secas definiam um cenário de catástrofe e angústia compondo um quadro, como expressou o jornal Sobralense em 1875, ao mesmo tempo sublime e pitoresco, descortinado pelo dedo onipotente do Eterno. Tanto Santana quanto Acaraú tiveram um inverno rigoroso. Em Santana se reclamava do silêncio a respeito desses acontecimentos que continuavam a perseguir aquele lugar. A população diante de um rigoroso inverno rogava a Deus que não viessem novos acometimentos das pestes que no ano passado dizimaram com

\footnotetext{
96 Ibid.

97 Ibid.

98 Ibid.
} 
intensidade o povo que lutava com dificuldades para subsistir numa época em que o dinheiro se fazia tão custoso. ${ }^{99}$

As cheias provocavam a destruição de colheitas inteiras e com isso o aumento inflacionário sobre os gêneros de primeira necessidade, aspecto que tornava a fome um problema crônico em algumas localidades nos anos de inverno intenso. Isso era agudizado pela existência de uma carga tributária que penalizava a população pobre sertaneja. O memorialista das secas, Rodolfo Teófilo, apontava a seca como um elemento a recrudescer a realidade econômica da província marcada por uma carga tributária sobre o consumo. Apesar do bom inverno de 1875 a situação era aflitiva, provocando, segundo ele, desânimo na população por se depararem com aquele estado de coisas, e o baixo preço por que davam pelo fruto dos seus trabalhos, de maneira que a melhoria da população somente dependia da misericórdia divina.

Por outro lado o observador das secas, Rodolfo Teófilo, notava que os grandes invernos eram ás vezes tão fatais quanto às secas ${ }^{100}$. Entre as enchentes mais notáveis podemos citar as ocorridas nos anos de 1776, 1782, 1793 e 1805 que deixaram na tradição geral, memória tão desoladora quanto a seca de 1792. Exemplos disso foram os inverno de 1819, 1826 (este durou mais de 6 meses) e os de 1823, 1839, 1842, 1866, 1872, este último um dos mais extensos, que começou, na capital cearense, a 25 de novembro de 1871 e quase sem interrupção continuou intenso até junho e o de $1873 .{ }^{101}$ Portanto, a associação que se faz entre crise de abastecimento e seca é simplistas, pois as enchentes, ou os excessos de chuvas também provocavam uma situação calamitosa.

Os efeitos calamitosos das cheias foram observados também pelo Barão de Studart. Ele dizia que os invernos tal como as secas acarretavam grandes

\footnotetext{
${ }^{99}$ Ibid.

100 THEÓPHILO, Rodolfo. Op. cit, p. 80 e 81.

${ }^{101}$ Ibid, p. 13.
} 
infortúnios igualmente ao Ceará. De fato, alguns dos seus invernos, destruíam plantações, arrebatando os rebanhos, impedindo as colheitas, e fazendo desmoronar as habitações. São da lista desses anos desastrosos, para nos referirmos apenas ao século XIX, as enchentes ocorridas nos anos de 1805, 1819, 1832, 1839 e 1886 em que caíram em Fortaleza 2.453 milímetros. Em 1872, houve uma grande enchente do rio Jaguaribe. Em 1875 deu-se grande cheia do rio Acaraú. Em 1880, 1890 e 1894 o pluviômetro marcou em Fortaleza 2.719 milímetros. Em 1920 e 1921 foram inundadas as cidades de Aracati, União e Morada Nova. ${ }^{102}$

Essa subjugação dos cearenses à natureza e a falta de espírito científico e técnico tornaram a população refém de um problema que adquiriu uma gravidade maior do que deveria. Se existiam as enchentes, também existiam as secas. O problema da miséria, da fome e da peste era decorrente da situação social da população: analfabetismo, concentração fundiária, paternalismo e autoritarismo. Não obstante as intempéries, essa população ficava perdida no universo das disputas políticas pelo poder local entre potentados rurais.

Apesar das secas e das enchentes, a violência era calamidade maior que somente foi atacada pelos esforços do presidente Silveira da Motta que ao deixar o governo do Ceará foi sucedido por presidentes que deram continuidade ao seu trabalho de combate a criminalidade. Em 1869 governava o Ceará João Antonio de Araújo Freitas Henriques que determinou ao chefe de polícia Henrique Pereira de Lucena que fizesse um relatório circunstanciado sobre o estado da segurança pública. O chefe de polícia assegurou ao presidente que a este respeito, quer se referisse aos poucos dias de exercício de seu cargo, "quer a tempos mais remotos, era-lhe sobremodo lisonjeiro poder afirmar que a tranqüilidade tem permanecido sem

\footnotetext{
${ }^{102}$ STUDART, Barão de. Geografia do Ceará. Revista do Instituto do Ceará. Tomo XXXVIII, 1924, p.35.
} 
alteração". 103

Para avaliarmos se de 1850, início da administração Silveira da Mota a 1876 houve de fato um maior esforço de combate à criminalidade precisaríamos comparar o número de crimes cometidos com o número de criminosos capturados. Porém, pelo critério adotado precisamos observar as estatísticas à luz do seguinte problema: o cometimento de crimes ocorre ao longo do ano, mas a captura de criminosos leva às vezes vários anos até que as perseguições dêem resultados. E, além disso, há o problema da desconfiança, quanto ao rigor, das estatísticas de segurança pública indicadas nos relatórios provinciais. Em 1857 o presidente Francisco Xavier Paes Barreto ao passar a administração da província a Joaquim Mendes da Cruz Guimarães, alertou-lhe quanto aos dados estatísticos da segurança pública, dizendo não me atrevia a garantir "a exatidão destes dados". 104

Ele nutria a convicção de que além dos crimes registrados muitos outros foram cometidos "nos 14 meses decorridos de janeiro do ano passado a fevereiro deste ano". ${ }^{105}$ A razão para a desconfiança de Francisco Xavier era o desleixo de algumas autoridades e as facilidades que os malfeitores encontravam em um país vasto e pouco povoado para ocultar seus crimes. Com isso, muitos atentados, alguns horrorosos, a segurança individual e da propriedade passavam despercebidos e ficavam impunes. Mesmo presidentes cujas gestões se centraram no combate a criminalidade como fora o caso de Silveira da Mota, havia como ele próprio observou dificuldades em confeccionar mapas estatísticos dos presos existentes nas diversas cadeias da província para formar um juízo seguro acerca do número e da

\footnotetext{
${ }^{103}$ APEC - Relatório do presidente da província do Ceará João Antonio de Araújo Freitas Henriques 1 de setembro de 1869. Apensos - Relatório do Dr. Chefe de Polícia da Província Henrique Pereira de Lucena, p.1.

${ }^{104}$ APEC - Relatório do presidente da província do Ceará Francisco Xavier Paes Barreto. Tipografia Cearense: 25 de março de 1857, 1857, p.5.

${ }^{105}$ Ibid.
} 
importância das prisões que foram efetuadas durante a sua administração, e antes dela, devidos às distâncias em que se achavam as autoridades que lhe poderiam "dar as informações necessárias para a confecção do referido mapa, e o pouco tempo que lhe restava para fazer a exposição, tornam impraticável o meu desejo". 106

A despeito da falta de estatísticas da gestão Silveira da Motta, podemos avaliar seu êxito a partir da prisão durante a sua gestão de famosos criminosos como Condurú, Victor, Chico - Boi e Antonio Cirilo de Queirós. Mas, também a gestão anterior conseguiu fazer importantes capturas como as de Manoel Ferreira Lima Quixaba, Domingos Lopes de Sena, Alexandre Mourão e de José de Barros Melo, acusado de muitas mortes e de aterrorizar os municípios do Ipú e Inhamuns no Ceará e do Príncipe Imperial no Piauí. Ele se encontrava asilado nesse termo, onde foi preso por uma diligência apoiada em um acordo recíproco de cooperação entre as províncias vizinhas.

GRÁFICO 1

COMPARAÇÃO ENTRE O NÚMERO DE CRIMES COMETIDOS E O NÚMERO DE CRIMOSOS CAPTURADOSNO CEARÁ (1852-1876)

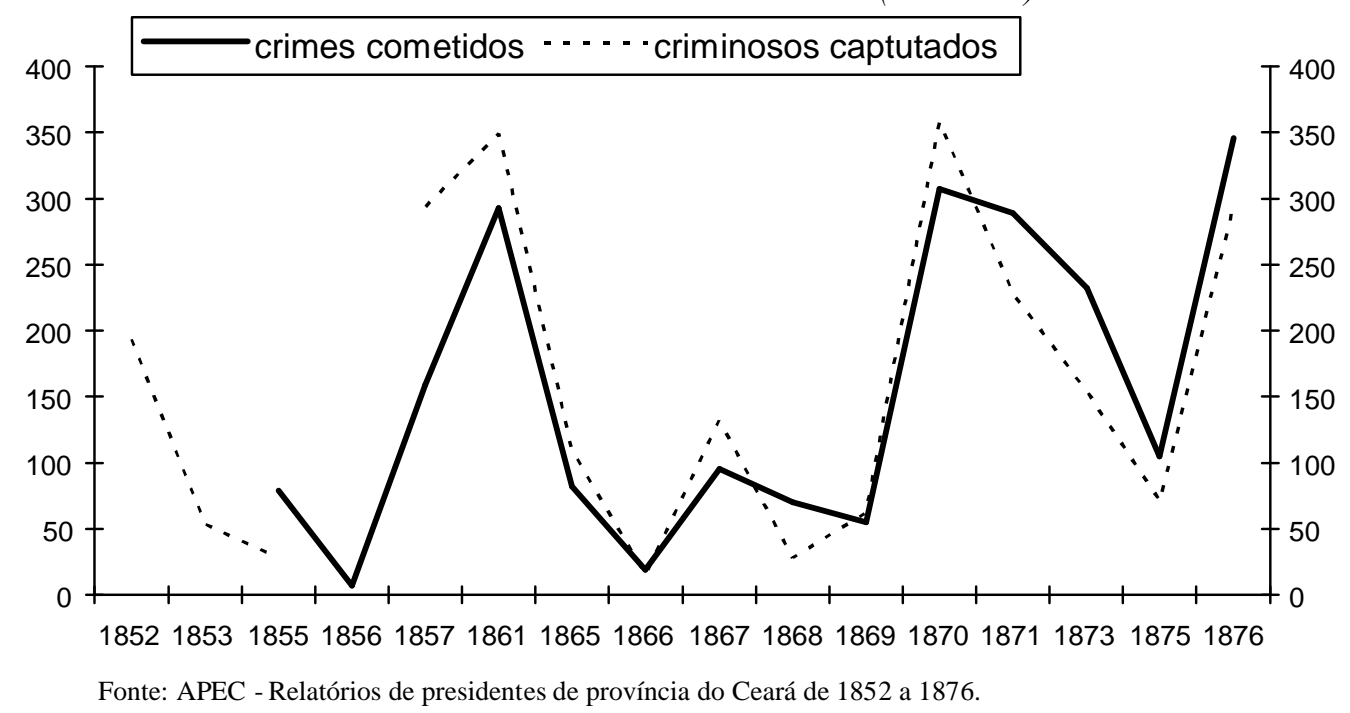

106 APEC - Relatório do presidente da província do Ceará Ignácio Francisco Silveira da Mota. Tipografia Cearense: 7 de julho de 1851, p. 04-05. 
De 1852 a 1876 houve um esforço por parte dos presidentes da província em combater a criminalidade no sertão do Ceará. O grande número de criminosos capturados resultou do melhor aparelhamento da polícia, da construção de novas cadeias e do envio de magistrados não envolvidos com as pendências no sertão. Medidas tomadas por Silveira da Motta e que foram continuadas pelos seus sucessores. O visconde de Sinimbú dando notícias do Brasil ao Pompeu, quando da estadia deste em Nice, na França, relatou que "os tumultos dos sertões do Norte extinguiram-se à vista das forças que ali apresentou o governo, e mais que tudo pelo recrutamento em massa daqueles infelizes". ${ }^{107}$ O êxito no combate à criminalidade nos sertões do Norte decorreu de uma política de segurança pública do Governo Imperial executada pelos governos das províncias que precisavam prestar contas ao Ministério da Justiça por meio de relatórios.

Esse processo de combate à violência no Norte foi percebido para o Ceará pelo jornal A Constituição que noticiou que em nove anos, de 1853 a 1861, poucos crimes de morte foram cometidos. A média de homicídios por ano, segundo o periódico, ficou na marca de 24,5. Considerando-se que a população da província era constituída de 500 mil habitantes, houve um assassinato para cada 17.856 pessoas. ${ }^{108}$ Esse processo foi contínuo até 1876 quando ocorreu a seca de $1877-79$ e a violência deixou paulatinamente de ser uma calamidade política para se tornar uma calamidade natural como veremos no próximo capítulo.

$$
* * *
$$

A violência no Ceará foi percebida como um problema político e econômico pelas elites dirigentes. Isso implicou na adoção de uma série de medidas por parte dos vários presidentes de província que governaram o Ceará dos anos 40 do

\footnotetext{
${ }^{107}$ CAMARA, José Aurélio Saraiva (org.). Op. cit., p.97.

${ }^{108}$ BPGMP - Jornal “A Constituição", 23 de novembro de 1865, p. 1.
} 
século XIX até a eclosão da "grande seca" (1877-79). Isso ocorreu como parte de um esforço administrativo geral que se deu com a retomada do poder central pelo Partido Conservador. Além das medidas de combate a violência, os governos tiveram a iniciativa de investir na modernização da agricultura, da pecuária e da atividade manufatureira. Com isso, a agroexportação adquiriu um impulso e possibilitou a acumulação endógena de capital necessário ao crescimento econômico. 


\section{Capítulo 2 - A Seca de 1877-79 e a lei forçada do Senador Pompeu}

Em 1877 teve início uma seca no Ceará que durou até 1879. Essa seca ficou conhecida como "grande seca" e repercutiu na imprensa nacional. As famílias sertanejas abandonaram seus domicílios no sertão em direção aos socorros públicos distribuídos no litoral. O governo imperial enviou gêneros alimentícios, os presidentes de províncias nomearam comissários de socorros e obras públicas aos indivíduos de destaque dos lugares. Em Fortaleza houve uma grande concentração de retirantes. Nesse período ganhou vazão a noção defendida pelo senador Pompeu de que as grandes secas eram cíclicas e por isso, em parte, estas se tornaram os acontecimentos mais importantes da região sobrepujando a violência e as enchentes.

\section{1. - As secas sobrepujam os demais acontecimentos.}

O processo de combate à violência no sertão foi interrompido com a declaração da seca de 1877, como podemos inferir da avaliação que fez da segurança pública e da propriedade privada o presidente José Júlio de Albuquerque Barros em 1879. De acordo com ele entre as causas conhecidas que atuavam permanentemente na sociedade para tornar precária a segurança dos direitos pessoais e da propriedade "O atraso da educação popular é a principal". 1

Para corroborar esse pensamento avaliou que a estatística criminal do

\footnotetext{
${ }^{1}$ APEC - Fala com que o presidente da província José Júlio de Albuquerque Barros abriu a $1^{\text {a }}$ sessão da $24^{\text {a }}$ legislatura, Fortaleza: Tipografia brasileira, 1879, p.5.
} 
Brasil na época demonstrava que mais de duas partes dos crimes eram "cometidos por analfabetos". 2 De fato, a educação popular era um fator importante na diminuição da criminalidade, porém a migração em massa do sertão para o litoral agravou ainda mais esse quadro, com uma acentuada queda na matrícula porque as famílias tiveram que abandonar os seus domicílios, como mostra o gráfico abaixo:

GRÁFICO 2

EVOLUÇÃO DA MÁTRICULA ESCOLAR NO CEARÁ (1845-1881)

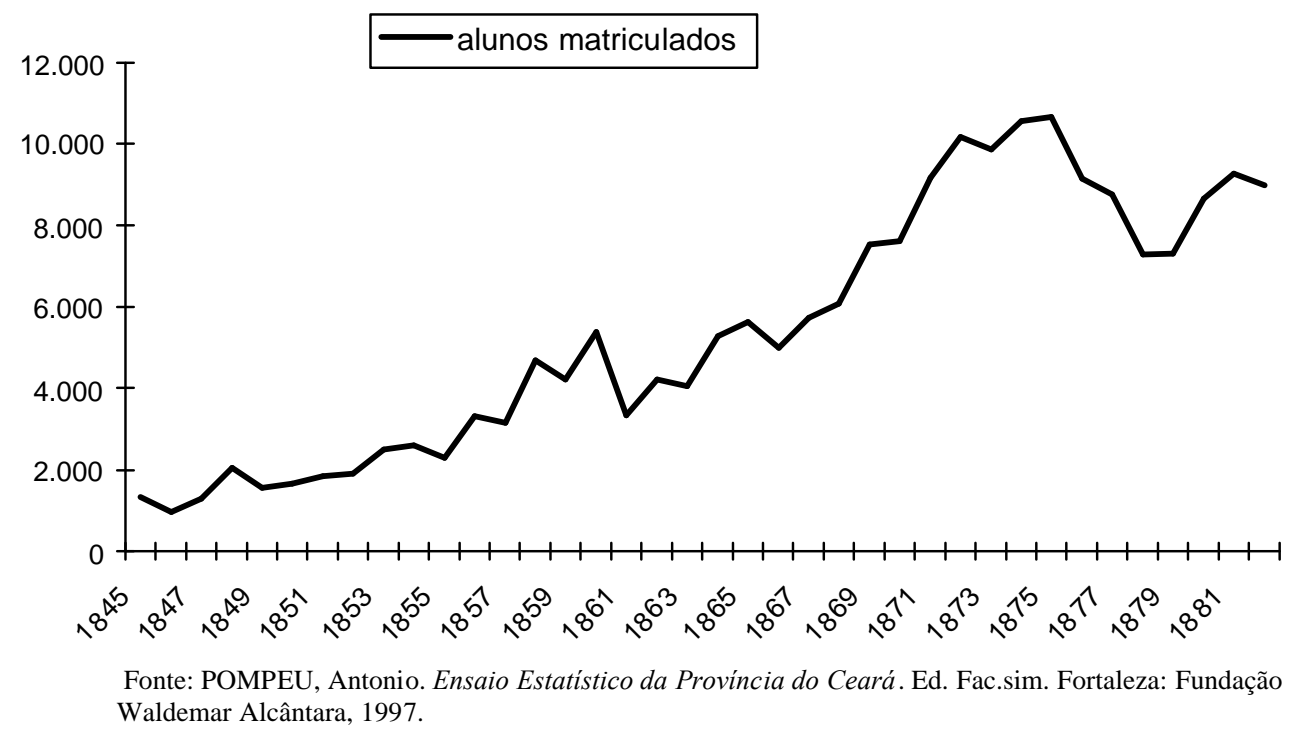

O presidente José Júlio de Albuquerque Barros embora acusasse a falta de educação do povo como um elemento desencadeador da violência, não deixou de reconhecer outros aspectos como a disseminação dos habitantes pela província e a falta de comunicações rápidas que impediam as autoridades de se apresentarem a tempo de prevenir ou reprimir os delitos, levando com que a certeza dessa impossibilidade fosse um estímulo ao crime. A partir de 1877, quando a oligarquia Acióli começou a se estabeleceu no poder, nota-se que os governos passaram a ter uma atitude de inércia em relação à violência. Como justificou o presidente era difícil combatê-la, pois esta se devia em grande parte a 
falta de educação do povo. Essa postura administrativa era oposta a que teve o presidente Silveira da Motta em 1851 e seus sucessores.

Recrudesceu a violência na província, pois salvo casos excepcionais, a ação pública só se estendia aos crimes mais graves. Muitos delitos ficavam impunes, porque as despesas judiciais e as delongas do julgamento demoviam os ofendidos da vontade de exercerem o direito de queixa. Disso resultava a vendeta particular que produzia novos crimes, e a impunidade que tanto concorria para formar os facínoras. Com isso, a propriedade estava, em grande parte, confiada à fé pública, pois a vastidão dos domínios territoriais, as confusões de limites, o espalhamento de gados pelos campos e matas, tornavam freqüentes as invasões, os conflitos, depredações e furtos. O governo de José Júlio, em razão da preocupação com seca, mas também por inoperância própria não atuava no combate à criminalidade.

A certeza da pena seria um corretivo eficaz, porém a insuficiência da força policial para a perseguição aos criminosos, as dificuldades dos processos e a pouca segurança de algumas prisões faziam com que muitos escapassem ao braço da lei. A estas causas gerais, concluiu o presidente que a calamidade da seca, a miséria dela decorrente, a interrupção dos trabalhos rurais e a aglomeração de uma população faminta nas cidades, vilas e nos "lugares mais favorecidos pela natureza, contribuiu para a multiplicação dos crimes". ${ }^{3} \mathrm{O}$ presidente José Júlio ao afirmar isso deixou de considerar que o efeito dos socorros públicos sobre as famílias cearenses era avassalador. O colapso do precário sistema de ensino e o aumento da violência era o ônus que o governo pagava por apoiar a migração. Para tentar manter a ordem, perseguir os criminosos, e resguardar os direitos individuais ele conseguiu junto ao Governo Imperial que aumentasse a força 
militar com duzentas praças de infantaria, e uma companhia de cavalaria.

Se o governo não realizou capturas depois da seca de 1877 , por outro lado, a criminalidade diminuiu porque os retirantes eram fiscalizados ou por comissários, ou pela própria polícia destacada para os abarracamentos de retirantes. O governo não tinha feito nenhuma captura porque em razão da seca não foi possível perseguir os criminosos porque a província sofria um colapso social e econômico com a polícia muitas vezes sendo usada para fiscalizar turmas de trabalhadores ou manter a segurança durante a distribuição de socorros públicos.

Se estivermos certos em afirmar que após 1877 a violência foi sobrepujada em importância pelas secas precisamos novamente comparar a relação entre crimes cometidos e criminosos capturados, como fizemos após gestão Silveira da Motta. Ao tentarmos comparar o número dos crimes cometidos com o de criminosos capturados após a seca de 1877-79 observamos que os relatórios traziam o número de crimes cometidos, mas não o de criminosos capturados. Em geral essas duas informações eram colocadas lado a lado. Porém, como não houve esforço administrativo nesse sentido, esse dado era cada vez mais ausente dos relatórios. 


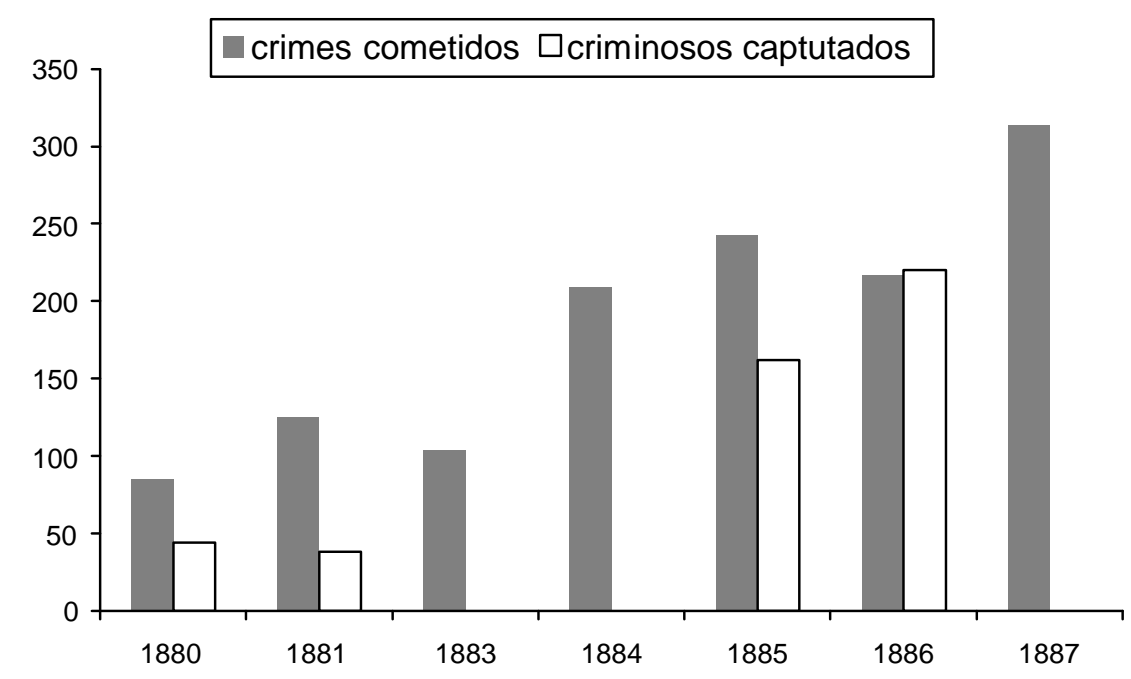

Fonte: APEC - Relatórios de presidentes de província, 1877-1887.

No período de 1880 a 1887, oito anos após o término da seca de 187779, os relatórios de presidentes de província continuaram trazendo as estatísticas criminais, comparando o número de crimes cometidos com o de criminosos capturados. Mas, a partir de 1888, esse dado desapareceu dos relatórios até depois de 1900, diferente do período anterior (1852 a 1876) quando essa comparação foi constante. Uma outra mudança importante era que os dados de 1852 a 1876 expressavam melhores os índices porque havia um esforço efetivo de combate à criminalidade. Porém, em relação ao período pós-seca observou o presidente José Júlio de Albuquerque Barros em relação às estatísticas de 1880 que aqueles algarismos não exprimiam a "totalidade dos delitos, porque muitos deles, como o de furto, que só excepcionalmente dão lugar ao procedimento oficial, de ser trazidos ao conhecimento da autoridade". ${ }^{4}$

No relatório que apresentou ao presidente Bezerril Fontenele em 1894 o secretário dos Negócios da Justiça Valdemiro Moreira observou que o estado da segurança individual e da propriedade não era tão lisonjeio "devido à falta de educação e de instrução das classes inferiores e ao vício da embriagues, causas

\footnotetext{
${ }^{4}$ APEC - Fala do presidente José Júlio de Albuquerque Barros. $1^{\text {a }}$ sessão da $25^{\text {a }}$ legislatura da Assembléia provincial. Fortaleza: 1 de julho de 1880., 1880, p. 5.
} 
preponderantes dos delitos". ${ }^{5}$ Assim, como o presidente José Júlio ele atribuiu aos indivíduos sem educação e embriagados a responsabilidade pelos índices elevados de violência minimizando a margem de ação do estado. Em 1896 ele deu a mesma explicação ao relatar o estado ruim da segurança individual alegando que isso se devia "a falta de educação e de instrução das classes inferiores da população e ao abuso de bebidas alcoólicas". ${ }^{6}$

A violência foi eclipsada como problema político, sendo substituída pela seca. Porém, diferente da violência, as medidas tomadas contra as secas terminavam agravando o problema. O presidente da província Nogueira Acióli ao comparar a mortalidade no ano de 1889 em relação ao ano de 1890, quando houve seca, percebeu que durante as enchentes, podia-se notar uma tendência de queda na mortalidade, enquanto durante as secas a tendência foi sempre de aumento da mortalidade. Vejamos o gráfico a seguir:

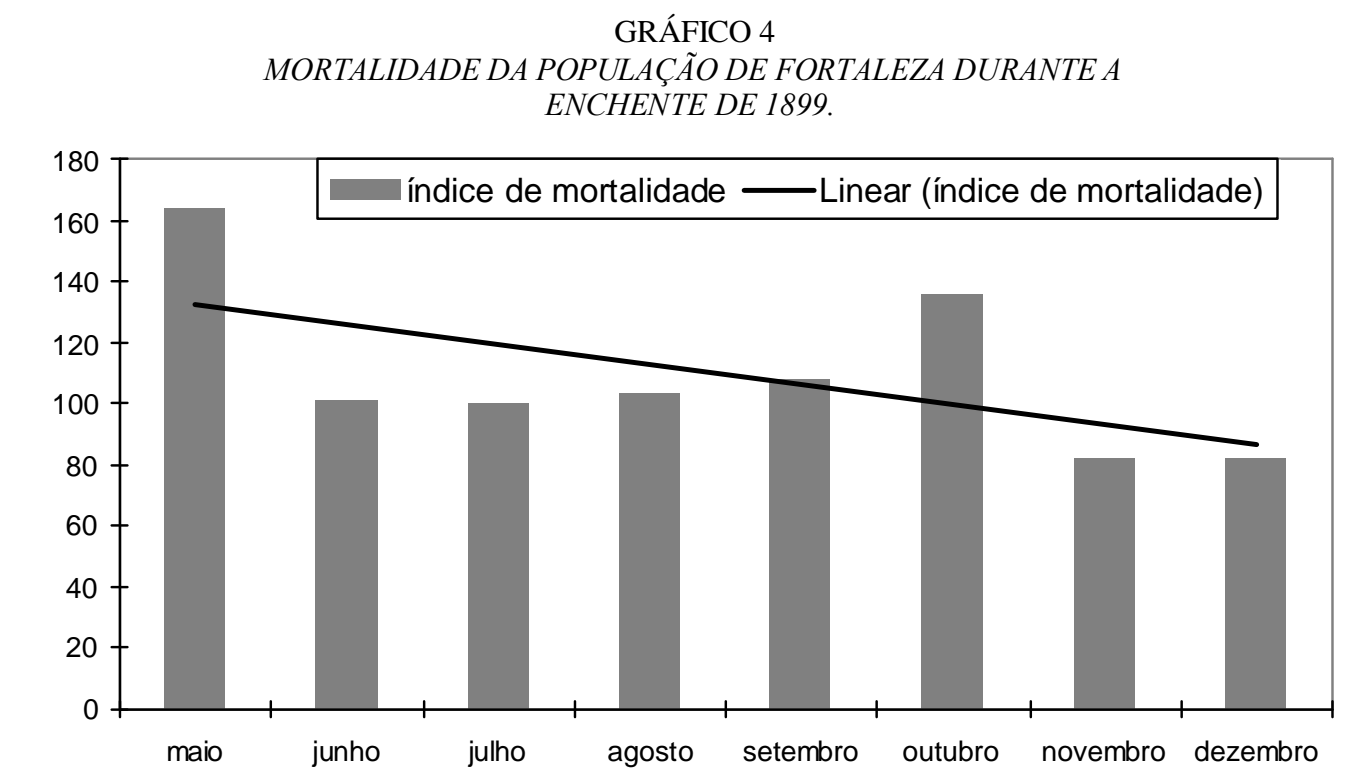

Fonte: APEC - Relatório de presidente de província, 1899.

As enchentes tinham conseqüências semelhantes às secas como o

${ }^{5}$ APEC - Relatório do Secretário dos Negócios da Justiça coronel Valdemiro Moreira, junho de 1894, p.92.

${ }^{6}$ APEC - Relatório do Secretário dos Negócios da Justiça coronel Valdemiro Moreira, maio de 1896, p.110. 
surgimento de doenças, a perda das colheitas e a formação de uma população de desabrigados. O termômetro para as secas e as enchentes era a cidade de Fortaleza para onde se dirigiam os retirantes em busca de socorros públicos. Essa tendência de queda na mortalidade na capital cearense chamou a atenção do presidente Nogueira Acióli que avaliou "modificou-se, entretanto esta triste situação ainda em dias do mês de maio e foi a mesma cifra diminuindo apesar de prolongar-se o inverno até o mês de agosto". 7 As secas e as enchentes embora fossem calamidades de efeitos similares sobre a população eram tratadas de maneira diferente.

Em parte essa tendência de queda se devia ao modo como se dava o atendimento no interior onde grassavam as febres perniciosas e de caráter epidêmico, que atacaram os habitantes de muitas localidades, principalmente em Maranguape, Barbalha, Boa Viagem e Paracurú para cujas localidades o presidente da província remeteu "convenientes ambulâncias". ${ }^{8}$ Essa era a diferença principal entre uma seca e uma enchente, pois durante as cheias o governo destinava ambulâncias e socorros públicos, enquanto durante as secas o modelo de assistência consistia no incentivo a migração à capital cearense porque a seca era considerada um evento generalizado, embora ela assim como as enchentes também não atingissem o Ceará de modo homogêneo.

Em razão do modelo de assistência aos desvalidos (veremos em detalhe no capítulo 4) as secas provocavam um maior abandono dos domicílios do que as enchentes, aspecto importante não apenas na seca de 1877-79, mas nas seguintes $(1888-89,1894,1900)$ foi que mesmo depois de declaradas terminadas

\footnotetext{
${ }^{7}$ APEC - Mensagem apresentada à Assembléia Legislativa do Ceará pelo presidente do Estado Antonio Pinto Nogueira Acióli, em 1 de julho de 1900. Fortaleza: Tipografia da "A República", Rua Floriano Peixoto 55-A, p.8.

${ }^{8}$ Ibid., p.9.
} 
pelo governo, elas deixaram resquícios como notou o presidente da província em 1881, André Fleury. Quando ele chegou ao Ceará, encontrou um grande número de indigentes e muitas órfãs asiladas no abarracamento da Jacarecanga. ${ }^{9}$ A indigência e a orfandade eram as principais conseqüências deixadas pela seca. Muitos indigentes eram ulcerosos e viviam da caridade pública. Fleury, diante desse quadro, enviou uma representação ao Ministro do Império, que a respeito da qual foi autorizado a dar uma diária de 400 réis para o tratamento dos enfermos, na Santa Casa de Misericórdia. Com este serviço se gastou aproximadamente 16 dezesseis contos de réis, relativos à abertura de dois créditos, realizados em 30 de agosto de 1880 e em 12 de janeiro de $1881 .{ }^{10}$

Assim, grandes recursos eram gastos com o atendimento das vítimas da seca. A Santa Casa era mobilizada para atender os doentes e ofícios eram dirigidos a ministros e secretários com o intuito de angariar mais verbas para assistir os retirantes. Ademais, teve início a constituição de formas de atendimento como a concessão de trabalho, esmolas e verbas para a migração. Em 1881 por já estar em funcionamento a estrada de ferro Fortaleza-Baturité, o ministro da agricultura permitiu a concessão de passagens nos trens aos indigentes que ainda haviam abandonado os seus lares, desde o tempo da seca, e que não pudessem regressar aos seus domicílios. Foram concedidas passagens a 370 pessoas que com isso puderam retornar ao interior da província. Quando melhoravam as circunstancias, cessava a concessão de passagens e os enfermos, por conta do governo, eram tratadas na Santa Casa de Misericórdia e mantidas à custa dos cofres provinciais. ${ }^{11}$

9 APEC - Relatório do presidente da província André Augusto de Pádua Fleury. Fortaleza: tipografia do Cearense, $1^{\circ}$ de abril de 1881, p.55.

${ }^{10}$ Ibid.

${ }^{11}$ Ibid. 
Ainda em 1881 o governo da província continuava atendendo os remanescentes das secas com recursos dos últimos socorros públicos. Com isso, mesmo após terminar a seca a questão da tranqüilidade pública demorava a voltar a monopolizar os esforços do governo, pois as secas passaram a ocupar a partir desse momento a primeira página dos relatórios e dos jornais locais, tanto nos anos de secas, quanto nos períodos de normalidade. Desse modo, a partir de 1877 a seca se firmou não apenas como calamidade social, pois isso ela sempre foi, mas se tornou um fenômeno capaz de sobrepujar os demais acontecimentos, de engolfá-los e torná-los dependentes dela, como as enchentes, a violência e a própria família.

A seca de 1877 se tornou o primeiro assunto a ser exposto nos relatórios que os presidentes de província enviavam à Assembléia Legislativa Provincial. Desse modo, a dificuldade do viajante Daniel Kidder, na primeira metade do século XIX, em decidir qual a maior calamidade que assolava o povo sertanejo (as secas ou as inundações) foi dirimida em 1877, através da fala do presidente da província Caetano Estelita. De acordo com ele a província atravessava uma crise tremenda, passava por uma daquelas secas desoladoras, que desde o século passado, vinha devastando o seu solo, em períodos mais ou menos largos, alastrando-o de ruínas, "consumindo suas forças presentes e agourentando o seu futuro". 12

Caetano Estelita refez a seca temporalmente em seu discurso. No relatório aos deputados provinciais, definiu-a como calamidade no século XVII, quando não havia tal diferenciação, enfatizando seus efeitos devastadores no presente século XIX, e atribuindo-lhe a capacidade de trazer vaticínios no futuro

12 APEC - Fala do Presidente da Província do Ceará Caetano Estelita Cavalcante Pessoa. $2^{\text {a }}$ Sessão da $23^{a}$ Legislatura, 2 de julho de 1877, p.36. 
século $\mathrm{XX}$, adquirindo um sentido atemporal. A seca se tornou um fenômeno de natureza social na medida em que passou a fazer parte da memória do povo cearense e era associada a um passado relembrado regularmente, como se pode depreender de uma modinha publicada no jornal $\mathrm{O}$ Vadio que circulou em Fortaleza no ano de 1899. A modinha mostrava a seca como parte memória da memória do povo. ${ }^{13}$

Dentre as várias conseqüências apontadas pelas autoridades e sentidas pela sociedade, a degeneração moral da família foi a maior delas. Isso ocorreu em decorrência das condições a que foram sujeitados os menores, filhos e filhas dos sertanejos que migraram para diversas cidades no Ceará. O jornalista e abolicionista José do Patrocínio em visita à capital cearense para acompanhar a seca de 1877, registrou suas impressões nos vários artigos escritos para a Gazeta de Notícias do Rio de Janeiro. A seca e a pobreza, segundo ele, legalizadas pela desigualdade social colocavam em risco a moral familiar levando a que "grinaldas" fossem vendidas por "um punhado de farinha". ${ }^{14}$ Muitas famílias entregavam suas filhas em casamento a homens que se aproveitavam da situação de miséria em que viviam. Era preferível ver a filha alvo de exploração sexual do que morta de fome pelas vielas.

Embora antes de 1877 as ações violentas fossem vistas como uma depreciação moral, ${ }^{15}$ ela consistia na base de sustentação da sociedade cearense. Contudo, com o advento da "grande seca" houve como consequiência a desorganização de um modelo de família baseado no primado da honra, para outro estribado na sujeição da família à seca e à migração. Essa mudança de paradigma

\footnotetext{
${ }^{13}$ BNRJ - Divisões de Periódico. Jornal "O Vadio", Fortaleza, 24 de junho de 1899, p.4.

${ }_{14}$ BNRJ - Setor de microfilmagem: Jornal O Besouro 04/05/1878, p. 37.

15 FRANCO, Maria Sylvia de Carvalho. Os homens livres na ordem escravocrata. São Paulo, Ática, 1974.
} 
foi acompanhada pela reestruturação domiciliar ocorrida nas cidades pólos de atração dos retirantes, pela organização das frentes de trabalho utilizadas nas obras públicas e pela efetivação de uma prática migratória. Se a violência que alçava agregados à condição de quase parentes em razão dos crimes que poderiam vir a cometer, a seca por sua vez tornou difícil conceituar a família cearense porque ao longo da segunda metade do século XIX e início do XX ela existiu, sobretudo nos anos de seca de modo sempre instável, cuja formação dependia do desenrolar das necessidades de sobrevivência.

A violência praticada pelos potentados políticos nas disputas pelo poder e as agressões quotidianas relacionadas à defesa da honra das famílias existiram devido à precariedade do aparelho estatal e a sua falta de legitimidade social, pois o estado estava sujeito aos interesses dos latifundiários e pouco podia fazer para obstar as lutas entre famílias. No entanto, com a seca o estado adquiriu uma função social importante através de seu caráter assistencial. Assim, se na primeira metade do século XIX a preocupação era edificar cadeias para prenderem criminosos, na segunda metade passou a ser construir abarracamentos, criar comissões de socorros públicos e atender viúvas e órfãos.

Esse processo de transformação da seca em questão social tirou a população pobre sertaneja do ostracismo político e histórico, dando-lhe visibilidade, e com isso, erigindo-a da posição de coadjuvante dos conflitos protagonizados pelos grupos políticos locais ao longo da primeira metade do século XIX para o cenário principal dos acontecimentos. Essa ruptura ocorreu a partir da experiência migratória do retirante que viu na migração para cidades litorâneas e com condições de atendimento uma estratégia de resistência ao flagelo da seca. Ao migrar a partir de 1877 o agricultor passou a encontrar uma 
estrutura de assistência que lhe fornecia abrigo, trabalho e alimentação.

Nesse sentido, a partir de 1877 a multidão, ou apenas pequenos grupos de retirante tomou o espaço político dominado até a primeira metade do século XIX pelos mais afamaliados. Ou seja, pelas famosas famílias dos diversos lugares. Por outro lado, se as elites diminuíram sua ação política no terreno da violência, que punha em risco sua extinção física e eleitoral, com o estatuto da seca como calamidade maior, tem-se um novo cenário sobre o qual as elites irão focalizar seu desejo de poder e governo. Ademais, a seca une as elites, ou as elites se unem em torno da seca contra os governos do Império e da República.

Pedro Augusto Borges em 1900, no seu relatório à Assembléia Legislativa Estadual, no item tranqüilidade pública fez uma ligação entre seca e criminalidade. Para ele a segurança individual e da propriedade se ressentiu da crise climatérica que o estado atravessou, mas não tanto quanto se receava. Para Borges a extensão da calamidade poderia ter produzido um quadro de violência ainda maior. Na verdade os efeitos da seca sobre a violência eram sempre proporcionais. No entanto, como os governos anteriores sua intenção era sobremodo valorizar a seca de 1900 , ressaltando a paralisação dos trabalhos rurais, a miséria geral das classes desafortunadas, lançadas à ociosidade e sem meios de subsistência. Essa população encontrava, segundo ele, na desorganização da vida social o incitamento das paixões para ataques sucessivos à segurança das pessoas, ao direito de propriedade. ${ }^{16}$

A seca que se abateu sobre o Ceará nos anos de 1900 e 1901 teve, como as demais, a família como pêndulo para se justificar como calamidade. Borges afirmou ao governo federal que a prova mais cabal da fase aguda que a

\footnotetext{
${ }^{16}$ APEC - Mensagem do Presidente do Estado do Ceará Pedro Augusto Borges. Fortaleza: $1^{\circ}$ de julho de 1901, p. 4.
} 
calamidade ia tocando, estava na emigração sempre crescente e ruinosa, que se produzia, porque para ele ninguém abandonava o seu lar e expunha "sua família a longas e penosas jornadas, em busca de um refúgio desconhecido, senão na última extremidade". ${ }^{17}$ Ele e os presidentes anteriores procuram sempre afirmar a impossibilidade da população resistir à necessidade de migrar e permanecer no campo. Se de forma alguma devemos subestimar os efeitos da seca sobre os meios de sobrevivência das famílias, não devemos igualmente desconsiderar o que a população era atraída pelos socorros públicos concentrados nas vilas e cidades litorâneas.

O panorama apresentado por Pedro Augusto Borges, na sua mensagem dirigida à Assembléia Legislativa do Ceará era semelhante ao evidenciado pelos governantes anteriores em tempos de seca. A segurança individual e da propriedade se tornando vacilantes, incerta e desamparada nas localidades do interior, principalmente naquelas onde se formavam grupos de criminosos, que faziam depredações, cometendo extorsões da maior gravidade, arvorando-se até em juizes para liquidação de dividas e questões de terra. ${ }^{18}$ Apesar de a violência continuar grassando em várias localidades do interior da província, o governo era vacilante em tratar do problema, pois a violência não era mais a principal calamidade.

A ocorrência das secas ocupava o noticiário dos jornais, sendo apresentadas como catástrofes naturais que atingiam toda a província, quando muitas vezes durante uma estiagem prolongada existiam localidades que pareciam estarem em períodos de inverno como observou Pedro Augusto Borges em 1903,

\footnotetext{
${ }^{17}$ BPGMP - Mensagem apresentada à Assembléia Legislativa do Ceará em $1^{\circ}$ de julho de 1901, pelo presidente do estado Dr. Pedro Augusto Borges, Tipografia Econômica, 1901, p.25.

${ }^{18}$ BPGMP - Mensagem apresentada a Assembléia Legislativa do Ceará em $1^{\circ}$ de julho de 1903, pelo presidente de Estado Dr. Pedro Augusto Borges, Ceará-Fortaleza, Tipografia Minerva, de Assis Bezerra, p. 4.
} 
ao se referir à seca de 1900. De acordo com ele os efeitos dessa seca se prolongaram de maneira mais atenuada graças aos invernos de caráter regional. ${ }^{19}$ Nas secas anteriores também houve invernos de caráter regional. No entanto, a pressão exercida pelos socorros públicos obrigava todos a migrarem. Com isso, a população do Ceará se tornou cada vez mais dependente dos socorros públicos do estado e este, por sua vez, dos recursos arrecadados pelo Governo Federal.

Nogueira Acióli compreendeu bem essa situação. Indicou na sua mensagem à Assembléia Legislativa que a sua relação com a União, na figura do presidente Rodrigues Alves era de cortesia e deferência mantidas pela União e o Estado, estabelecendo entre os representantes dos poderes públicos de uma e de outra esfera certas afinidades e determinando inteira harmonia de vistas no que concernia ás linhas gerais da política nacional. Isso era para ele um fator poderoso na manutenção da ordem e acatamento ao princípio da autoridade no Ceará. Acióli consignava esse fato, como instrumento de progresso local, pelos solícitos cuidados incessantemente reclamados da Federação as necessidades de uma terra, como a cearense, assolada pelo flagelo da seca. ${ }^{20}$ Devido a ajuda federal era bastante lisonjeira a situação em que se encontrava o Ceará, após as sucessivas crises climáticas que com mais ou menos intensidade tinha assolado o Ceará, exaurindo-lhe as forças e perturbando-lhe a vida em suas múltiplas relações.

Apesar dessa situação lisonjeira Nogueira Acióli 1905, ao constatar o atraso do Ceará no ramo da instrução pública ponderou que as causas que concorriam para isso era a descrença nos efeitos da educação, a falta de estímulo dos professores, a falta do hábito de leitura da população e até causas de natureza

\footnotetext{
${ }^{19}$ BPGMP - Mensagem apresentada à Assembléia Legislativa do Ceará em $1^{\circ}$ de julho de 1904, pelo presidente de Estado Dr. Pedro Augusto Borges, Ceará-Fortaleza, Tipografia Minerva, de Assis Bezerra, p. 3.

${ }_{20}$ APEC - Mensagem dirigida à Assembléia Legislativa do Ceará em 17 de julho de 1905 pelo presidente do estado Dr. Antonio Pinto Nogueira Acióli, Tipo-Litografia a vapor, 1905, p. 7.
} 
psíquica como as secas. ${ }^{21} \mathrm{O}$ que ele não lembrou de dizer ao presidente Rodrigues Alves foi que isso começou justamente quando seu sogro e o ministro Sinimbú fortaleceram a bancada cearense em torno do problema da seca, transformando um assunto técnico ou de política local numa catástrofe nacional.

Se a seca era a raiz dos males do Ceará, a violência foi por Acióli menos denunciada e, pode-se afirmar subsumida em suas mensagens à Assembléia Legislativa. Evidenciava, contudo os casos comuns de transgressão da lei, que eram em sua opinião considerados inevitáveis, mesmo entre os povos mais cultos e melhor policiados. Dizia que nenhuma perturbação sofreu a ordem pública em todo o território do Estado. Apesar disso, houve na cidade de Lavras, no mês de novembro uma conflagração que ele minimizou considerando que ocorreu por efeito de causas puramente locais. Ora, as pendências locais eram verdadeiros focos de violência. No entanto, ele insistia em afirmar um estado de absoluta tranqüilidade. Esse estado para ele poria em destaque os sentimentos de ordem e respeito á lei do povo cearense. ${ }^{22}$ Nada mais inverídico dado os índices presentes nas estatísticas criminais e a forma como Acióli saiu do governo em 1912, deposto por uma revolta popular.

O Ceará foi entre as províncias do Norte, aquela para a qual convergiram os esforços de atendimento às famílias por meio dos socorros públicos. No Ceará as secas se sobrepuseram em importância aos demais acontecimentos. Isso serviu de referência às províncias como Paraíba, Piauí e Pernambuco. A violência foi substituída pela seca como principal problema social porque esta última abriu um campo de atuação para as elites grandes e pequenas, e ao mesmo, a consecução de obras públicas nos tempos de secas como a

${ }^{21}$ BPGMP - Mensagem dirigida à Assembléia Legislativa do Ceará em 17 de julho de 1905 pelo presidente do estado Dr. Antonio Pinto Nogueira Acióli, Tipo-litografia a vapor, 1905, p.17.

${ }^{22}$ APEC - Mensagem dirigida á Assembléia Legislativa do Ceará em $1^{\circ}$ de julho de 1908, p.12. 
construção de novas cadeias melhorou as condições para o combate à criminalidade. O jornal "Da União" publicou em 1909 um artigo sobre a cidade de Barbalha no qual informava que a Casa de Caridade fundada em 1869 pelo padre Ibiapina para abrigar meninas órfãs estava quase deserta devido à perseguição constante das secas que desde 1877 assolavam aquele lugar. ${ }^{23}$ Assim de 1877 e 1900 a população cearense sertaneja foi paulatinamente trocando o bacamarte pelo mocó em direção ao litoral e as províncias do Norte e Sul do Brasil.

O farmacêutico Rodolfo Teófilo, principal memorialista das secas do Ceará deu continuidade à noção deixada pelo senador, falecido em 1877, de que as grandes secas eram cíclicas, baseando-se nas observações feitas pelo senador Pompeu para o seu Ensaio Estatístico da Província do Ceará. Com base nisso, ele considerou que a seca de 1877-79 deveria ser enquadrada no rol das grandes secas listadas pelo geógrafo. Esta seca, no entanto, não apenas adquiriu a alcunha de "grande" como tornou a seca o acontecimento mais importante na província como constatou em 1889 o presidente Henrique D’Ávila. De acordo com ele, a seca era um evento que sobrepujava os demais acontecimentos em termos de importância. Com isso, a seca de 1877 foi o referencial para as secas posteriores, pois ela passou a ser chamada de a "seca tipo". Essa noção se vulgarizou entre os historiadores contemporâneos, para diferenciar uma estiagem da outra.

Sabemos, tomando-se como exemplo a estiagem de 1877, que uma seca pode ser grande quando ela causa enormes problemas sociais como mendicância, orfandade, abandono do lar, perda das colheitas, exploração sexual e epidemias só para citar algumas das suas mazelas. Entretanto, estas são conseqüências de problemas estruturais como queda no índice pluviométrico, diminuição do número

\footnotetext{
${ }^{23}$ STUDART, Barão de. Geografia Física e Política da Barbalha. Revista do Instituto do Ceará.. Ano XXIV, 1910, p. 03. (Documento da Coleção do Barão de Studart).
} 
de dias chovidos, interrupção da atividade produtiva. Nesse sentido, será que Rodolfo Teófilo tem razão ao considerar que a seca de 1877-79 pode ser chamada de "grande seca" ? E mais; será que esta fez parte de um ciclo antecedida pelas secas de 1711, 1776-77, 1723-27, 1744-45, 1809, 1844-45, assim também denominadas?

Thomaz Pompeu, entretanto ao falar das secas mais importantes dos séculos XVIII e XIX as definiu como as secas mais "notáveis", ou seja, aquelas dignas de notas. A única que ele chamou de "grande seca" foi a de 1791-93, a mais notável pelos seus efeitos assoladores, pois algumas ribeiras ficaram devastadas de gados, sendo preciso em 1794, refazerem-se o rebanho comprandose gado no Piauí. Informou ao senador Pompeu o corógrafo Aires de Casal que sete freguesias ficaram desertas, mas isso não é exato porque muitos contemporâneos dessa seca lhe informaram justamente o contrário. De acordo com a Memória do padre Joaquim José Pereira do Apodi os morcegos atacavam pessoas e animais ainda durante o dia, levando a que famílias inteiras morressem em casa e outras fossem encontradas mortas ao longo das estradas, pois nesse ano quase todas as fontes secaram. ${ }^{24}$

A respeito da seca de 1824-27, sabe-se apenas que esta se estendeu da Bahia ao Ceará. Já na seca de 1777-78, de acordo com informações dirigidas à Corte pela Provedoria da Fazenda o gado ficou reduzido à oitava parte. A seca de 1809 assolou os gados do Acaraú. Já a de 1817, segundo o governador Sampaio, foi tão forte quanto à de 1792. Contudo, a de 1824-25 "foi a mais terrível deste século pela grande mortalidade dos povos". ${ }^{25}$ Sobre todas essas secas, ele não se baseou em dados estatísticos, mas em notícias ou em impressões que lhes foram

\footnotetext{
24 POMPEU, Antonio. Ensaio Estatístico da Província do Ceará. Ed. Fac. sim. Fortaleza: Fundação Waldemar Alcântara, 1997, p. 101.

25 Ibid.
} 
repassadas por outras pessoas. Observe-se que o senador Pompeu se baseou em relatos, alguns até contraditórios como o oferecido por Aires de Casal, e outros carentes de maiores explicações como o caso do gado dizimado em 1793 e refeito em 1794. Além disso, de acordo com o próprio senador Pompeu, suas observações pluviométricas não têm exatidão rigorosa até 1858 e apenas dão uma idéia aproximada, porque no início não foram feitas com um hidrômetro, mas com um instrumento imperfeito.

Giácomo Raja Gabaglia, membro da Comissão Científica de Exploração que visitou o Ceará de 1859 a 1861 questionou nos seus Ensaios não apenas a noção de "grande seca", mas também a de que elas eram cíclicas. Para isso ele lançou mão das datas referidas pelo senador Pompeu. De acordo com este as secas de $1724,1778,1792,1809,1817,1825,1827,1837,1841,1845$ e 1858 foram grandes secas ou secas notáveis. Gabaglia avalia cada um desses anos, na intenção de mostrar que as calamidades ocorridas foram provocadas por outros

fatores que não a falta de chuvas. Segundo ele o ano de 1825 foi "enlutado com movimentos políticos que ocasionaram o abandono de todas as lavouras, trazendo os tristes efeitos da fome". ${ }^{26}$

Com relação à seca de 1837 Gabaglia citou um pronunciamento do senador Alencar aos eleitos para a Assembléia Provincial do Ceará, no qual dizia que apesar da ameaça da seca e do gado perdido o impacto sobre a arrecadação não foi considerável. ${ }^{27}$ No mesmo caso da seca de 1837 , achava-se a de 1841 . No dia 10 de setembro o presidente José Joaquim Coelho, dando conta dos negócios da província relatou que houve distúrbios nos termos de São Bernardo, Aracati, Sobral e Cascavel, bem como no Icó e Burití e apresenta o estado desanimador das

\footnotetext{
${ }^{26}$ GABAGLIA, Giácomo Raja. Ensaios sobre alguns melhoramentos tendentes à prosperidade da província do Ceará. Rio de Janeiro: Tipografia Nacional, 1877, p.43.

${ }^{27}$ Ibid., p. 44.
} 
finanças da província, mas "só de passagem menciona o estado de seca, isto quando trata da arrecadação de imposto do dízimo". ${ }^{28}$ Assim, também se pode observar que a seca de 1858 foi parcial pelo silêncio dos documentos sobre o assunto. Diante disso, ele excluiu algumas destas secas do rol das notáveis.

Para Gabaglia das 11 datas referidas por Pompeu como grandes secas apenas 5 delas poderiam ser assim denominadas, ficando as outras restantes classificadas como pequenas secas, "mas recorre-se a todas as 11 datas para formar a série que deve apresentar a lei periódica". ${ }^{29}$ Ao se recusar a aceitar que as seca de 1825, 1837, 1841 e 1858 possam ser chamadas de grandes secas Gabaglia refez o quadro das estiagens compondo a seguinte tabela:

TABELA 1

RECLASSIFICAÇÃO DAS GRANDES SECAS DO CEARÁ SEGUNDO GIÁCOMO RAJA GABAGLIA

\begin{tabular}{c|c}
\hline Grandes secas & Intervalos \\
\hline $1724-1778$ & 54 anos \\
$1778-1792$ & 14 anos \\
$1792-1809$ & 17 anos \\
$1809-1817$ & 08 anos \\
$1817-1827$ & 10 anos \\
\hline $1827-1845$ & 18 anos \\
\hline
\end{tabular}

Fonte: GABAGLIA, Giácomo Raja. Ensaios sobre alguns melhoramentos tendentes a prosperidade da província do Ceará. Rio de Janeiro: Tipografia Nacional, 1877, p. 46.

Com essa reclassificação, percebe-se que não havia regularidade nos episódios das grandes secas, portanto elas não eram nem cíclicas, nem movidas por nenhuma lei periódica. Para Gabaglia a teoria do senador Pompeu não passava de algo que ele denominou de "a lei forçada". Concluiu Gabaglia que se considerados os anos de 1724 a 1861, como anos atingidos por secas, obtém-se um intervalo de 136 anos, reduzidos os 11 apontados pelo senador Pompeu, dos quais "126 anos chuvosos contra 11 que não o foram!”. ${ }^{30}$ Portanto, para Gabaglia as secas não eram o motivo do atraso material da província e Pompeu tentou

\footnotetext{
${ }^{28}$ Ibid., p.44.

${ }^{29}$ Ibid., p.45.

${ }^{30}$ Ibid., p.46.
} 
segundo ele forçar uma lei que afirmava que as secas no Ceará eram cíclicas.

Um outro aspecto que Gabaglia ressaltou para criticar a noção de grande seca do senador Pompeu foi a abrangência ou a generalização das secas. Certas áreas da província ficavam imunes à estiagem como as serras da Ibiapaba, Meruoca, Uruberetama e muitas outras. Para se contrapor ao senador ele usou suas próprias afirmações como a que ele fez sobre a serra Grande, onde nunca se ouviu falar de chuva "mesmo nos famosos anos de 1778, 1792, 1809 e 1825? Lá nunca faltara chuva. Hoje está quase tão sujeita à seca como no sertão; e partes há em que falta até água para a bebida". Gabaglia questiona: “então o efeito foi de 1825 para cá?” ${ }^{31}$ Gabaglia atribuiu o impacto de algumas estiagens ocorridas de 1724 a 1850 à violência que grassava nos sertões do Ceará, pois de acordo com ele "quem poderia desejar desenvolver a agricultura e a pecuária? Quem teria coragem de reclamar as searas roubadas, os gados usurpados e dizimados?". ${ }^{32}$

Não existem dados seguros com relação às secas e a situação econômica da província até a primeira metade do século XIX. Contudo, após esse período e em relação às secas posteriores, há mais informações. Precisamos fazer uma análise dessa estiagem para compreendermos o que a diferenciou de todas as outras a ponto de alçá-la a categoria de principal evento. Para isso vamos utilizar os seguintes critérios: 1) índice pluviométrico, 2) número de dias chovidos, 3) impacto sobre a atividade econômica, 4) crescimento populacional e 5) duração da seca, com isso poderemos comparar as grandes secas com as secas comuns. Percebemos para o Ceará um padrão pluviométrico (entre 400 e 600 milímetros) a partir do qual definimos os períodos de secas.

Em 1877 choveu 473 milímetros, em 1878 choveu 580 e em 1879

\footnotetext{
31 Ibid.

${ }^{32}$ Ibid., p.55.
} 
choveu 596 milímetros, atingindo para os três anos uma média de 549,6 milímetros. Porém, em 1867 e 1874 choveu respectivamente 853 e 855 milímetros, anos estes considerados regulares, embora exceções em relação aos demais que apresentaram um índice pluviométrico acima dos 1.000 milímetros. Entretanto, o fato de em 1879 ter chovido apenas 259 milímetros a menos que 1874 seria suficiente para que esse ano fosse não apenas considerado de "seca", mas de "grande seca?" É importante notar que depois desta nenhuma outra seca foi chamada de "grande seca", nem mesmo a de 1915, conhecida simplesmente por a seca do Quinze.

Porém, os presidentes de província passaram a atribuir a situação econômica da província ao aparecimento das secas. O sucessor de Acióli na presidência do Ceará, Pedro Augusto Borges, observou que ao desembarcar no Ceará se deparou logo com "o mais tocante e vivo testemunho da infeliz situação dos retirantes de vários pontos do interior do estado". ${ }^{33}$ Estes retirantes, assim como nas secas anteriores, foram aglomerados na praia, nas praças, sob as árvores, em completo desabrigo e expostos aos raios de um sol abrasador. A dureza desse quadro se ampliava pelo aspecto da "nudez, da fome, da miséria que a todos atribulava!", completou o presidente. ${ }^{34}$

Além do problema da seca, constatou Pedro Augusto Borges que as contas públicas do Ceará vinham-se apresentando deficitárias de 1893 até 1900, ano de seu governo. Mas, como veremos adiante o déficit era retroativo a um período ainda maior. $\mathrm{O}$ estado teve nesses anos uma receita um pouco superior a dois mil contos que mal davam para cobrir as despesas. A exceção foi o ano de 1898 quando a exportação da goma elástica elevou a receita há um pouco mais de

\footnotetext{
${ }^{33}$ APEC - Mensagem do presidente Pedro Augusto Borges. Fortaleza: Tipografia Econômica, n. 43, Praça do Ferreira, 1 de julho de 1901, p.24.

${ }^{34}$ Ibid.
} 
três mil contos. Assim, o presidente Borges em 1901, diante de um estado com déficit na sua balança de pagamentos ponderou que apenas duas situações se apresentavam capazes de remedias as finanças do estado: a criação de novos impostos ou a redução da despesa pública.

Para ele a criação de novos tributos era uma medida temerária, sobrando a opção de procurar controlar os gastos públicos que exorbitavam em razão do clientelismo que caracterizava o modo como os liberais e os conservadores faziam para se fortalecerem politicamente e se manterem no poder. Não obstante, um estado deficitário, Pedro Augusto Borges avaliou que a seca na sua "marcha devastadora, ameaçava aniquilar as já depauperadas forças do estado" 35 , pois afetava a suas indústria, a sua produção, e o seu comércio; de modo que, lançar um empréstimo público em tais circunstâncias, "seria temeridade indesculpável pelo êxito problemático da operação, senão por seu completo naufrágio, tão aflitiva emergência era agravada pela desconfiança, que pesava no espírito público, de que faltaria o inverno no corrente ano". ${ }^{36}$

Diante disso, Borges alertou os deputados provinciais que não seria uma hipótese pessimista admitir que a receita orçada não cobriria a despesa orçada no ano de 1900, tendo em vista que "as principais fontes de renda, em conseqüência da crise climatérica que nos oprimiu, se acham depauperadas e sofrem sensível abatimento". ${ }^{37}$ Nesse sentido, a seca era um fator agravante das finanças do estado. O governo dependia dos tributos arrecadados da produção da lavoura e da pecuária para financiar as despesas públicas relativas a cada ano.

\footnotetext{
35 Ibid.

${ }^{36}$ Ibid, p.69.

${ }^{37}$ Ibid, p.70.
} 


\section{1. - Rodolfo Teófilo e a noção cíclica das grandes secas.}

Diante disso, Borges alertou os deputados provinciais que não seria uma hipótese pessimista admitir que a receita orçada não cobriria a despesa orçada no ano de 1900, tendo em vista que "as principais fontes de renda, em conseqüência da crise climatérica que nos oprimiu, se acham depauperadas e sofrem sensível abatimento". ${ }^{38}$ Nesse sentido, a seca era um fator agravante das finanças do estado. O governo dependia dos tributos arrecadados da produção da lavoura e da pecuária para financiar as despesas públicas relativas a cada ano. No entanto, se considerarmos o clima do Ceará dentro de qüinquiênio em que se inserem períodos de chuvas e de secas teremos um resultado diferente, do ponto de vista pluviométrico.

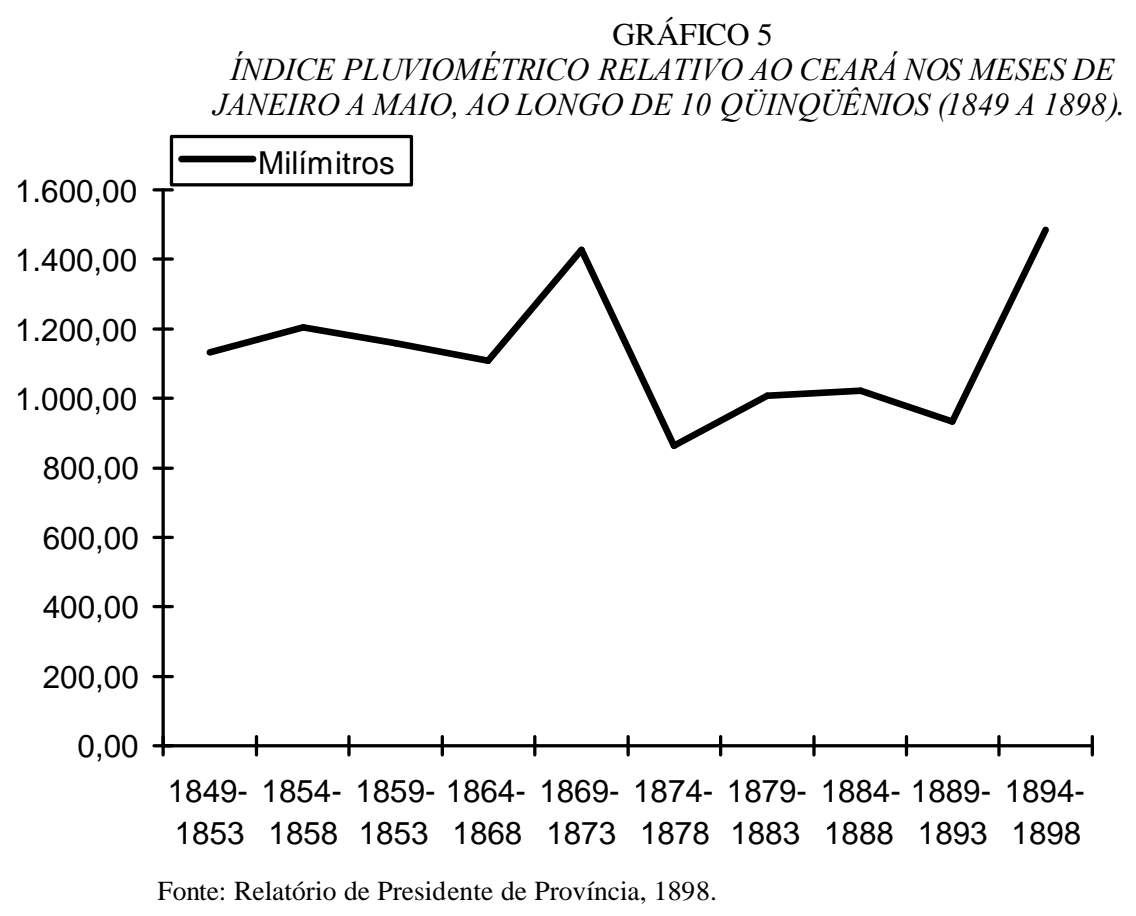

Como se pode observar do gráfico acima: as médias pluviométricas giraram entre 863 e 1.485 milímetros por ano. Se considerarmos o qüinqüênio

${ }^{38}$ Ibid. 
1894-1898, teremos 68 dias chovidos e uma média pluviométrica de 1.137 milímetros nos cinco primeiros meses do ano, ou seja, a caracterização de um período típico de inverno, mesmo entremeado por uma seca. Por outro lado, se levarmos em conta a sucessão de anos de seca com anos de invernos regulares e ou rigorosos chegamos a índices pluviométricos superiores a mil milímetros anuais. Esses dados climatológicos mostram que as secas se consideradas ao longo de qüinqüênios, por exemplo, teriam um impacto diminuto sobre a população. Outro aspecto importante a considerar é que no verão (estação seca) ocorre incidência pluviométrica. Considerando-se os verões mais secos de 1855 a 1898, obtém-se o seguinte resultado:

TABELA 2

RELAÇÃO DOS VERÕES MAIS SECOS DO CEARA (1855-1898).

\begin{tabular}{c|ccc}
\hline Período & Dias secos & Dias de chuvas & Total de dias de verão \\
\hline 1877 & 174 & 13 & 187 \\
1897 & 179 & 13 & 192 \\
1855 & 171 & 14 & 185 \\
1876 & 198 & 20 & 218 \\
1888 & 130 & 06 & 136 \\
1867 & 180 & 11 & 191 \\
1882 & 140 & 08 & 148 \\
1878 & 211 & 07 & 218 \\
1887 & 195 & 06 & 200 \\
1881 & 148 & 06 & 155 \\
1857 & 169 & 08 & 177 \\
1883 & 184 & 03 & 187 \\
1878 & 162 & 00 & 162 \\
\hline Total & 2.241 & 115 & 2.356 \\
\hline
\end{tabular}

Fonte: Relatório de Presidente de Província, 1898.

Entretanto, o impacto da seca sobre a atividade econômica da província foi pequeno no primeiro ano, mas em compensação os efeitos sobre a população foram devastadores. Mas, se considerarmos somente a seca de 1898 seus efeitos foram pouco divulgados e quase não repercutiu na imprensa, mas caracterizado como de seca porque a média pluviométrica foi de 434 milímetros e o número médio de dias chovidos foi de 54. Essa média foi ainda menor que na de 1877-79. Se compararmos o índice pluviométrico da seca de 1898 em relação a as principais secas do século XIX de que temos dados pluviométricos seguros, (nesse 
caso excluímos a seca de 1844-45), obtemos o seguinte resultado:

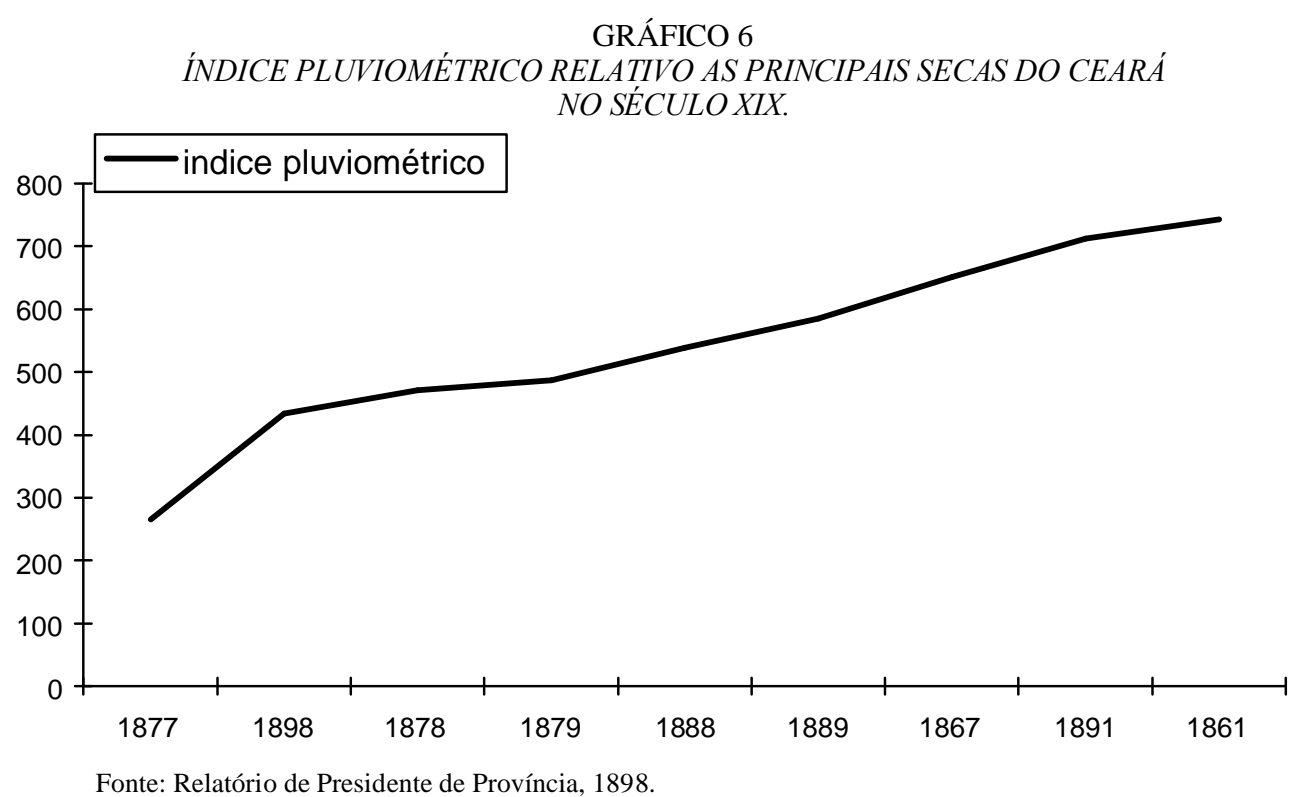

A seca de 1898 somente foi superada, em termos pluviométricos, pela chamada "grande seca" no seu primeiro ano (1877). Quanto a sua duração, poderse-ia alegar que ela não pode ser chamada de "grande seca" porque durou 1 ano, enquanto a de 1877 durou 3. Entretanto, no rol das grandes secas: 3 duraram apenas 1 ano e as outras 3 duraram 3 anos. Assim, sob o ponto de vista pluviométrico, a seca de 1877 , maior que a de 1898. Mais ainda, se observamos a história meteorológica do Ceará de 1710 até 1900 temos uma visão mais geral e podemos concluir que as secas correspondem a períodos de exceção e que, de maneira geral, a região nesse período viveu sob o predomínio climático de invernos regulares, como mostra o gráfico abaixo: 


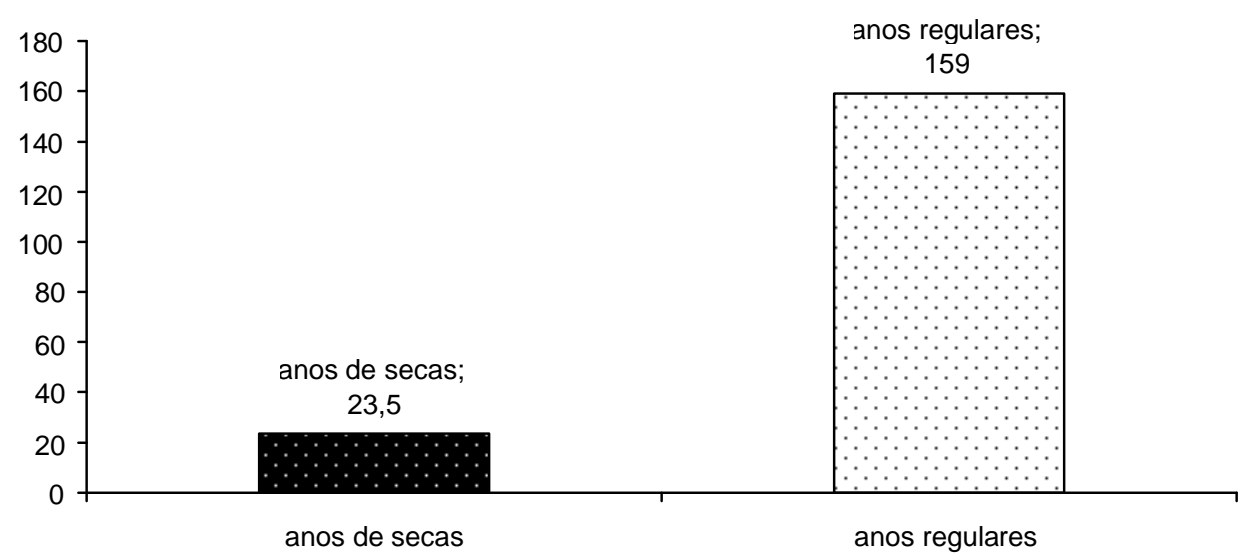

Fonte: POMPEU, Antonio. Ensaio Estatístico da Província do Ceará. Ed. Fac.sim. Fortaleza: Fundação Waldemar Alcântara, 1997.

Mas, se é possível no longo médio e longo prazo afirmar a suficiência de recursos hídricos, o que poderíamos dizer considerando uma seca como a de 1877 sob o ponto de vista do seu impacto pluviométrico e econômico? Nesse sentido, vamos considerar a afirmação de Rodolfo Teófilo a cerca do estado climatológico do Ceará. Segundo ele, a causa do aumento ou diminuição nas safras estava "na irregularidade das estações. Todas as lavouras mais ou menos se ressentem disso, porém a que mais sofre é a do café". 39

Comecemos então pela indústria extrativa e deixemos a produção cafeeira por último. Os principais produtos eram: a borracha, a cera de carnaúba, a palha de carnaúba, a cera de abelhas silvestres, as madeiras, as ervas medicinais, as salinas, a caça e a pesca. Analisemos os dados a respeito da borracha extraída da maniçoba e da mangabeira, obtem-se:

\footnotetext{
${ }^{39}$ TEÓFILO, Rodolfo. Op. cit, p. 25.
} 
PORTO DE FORTALEZA (1866 A 1876)

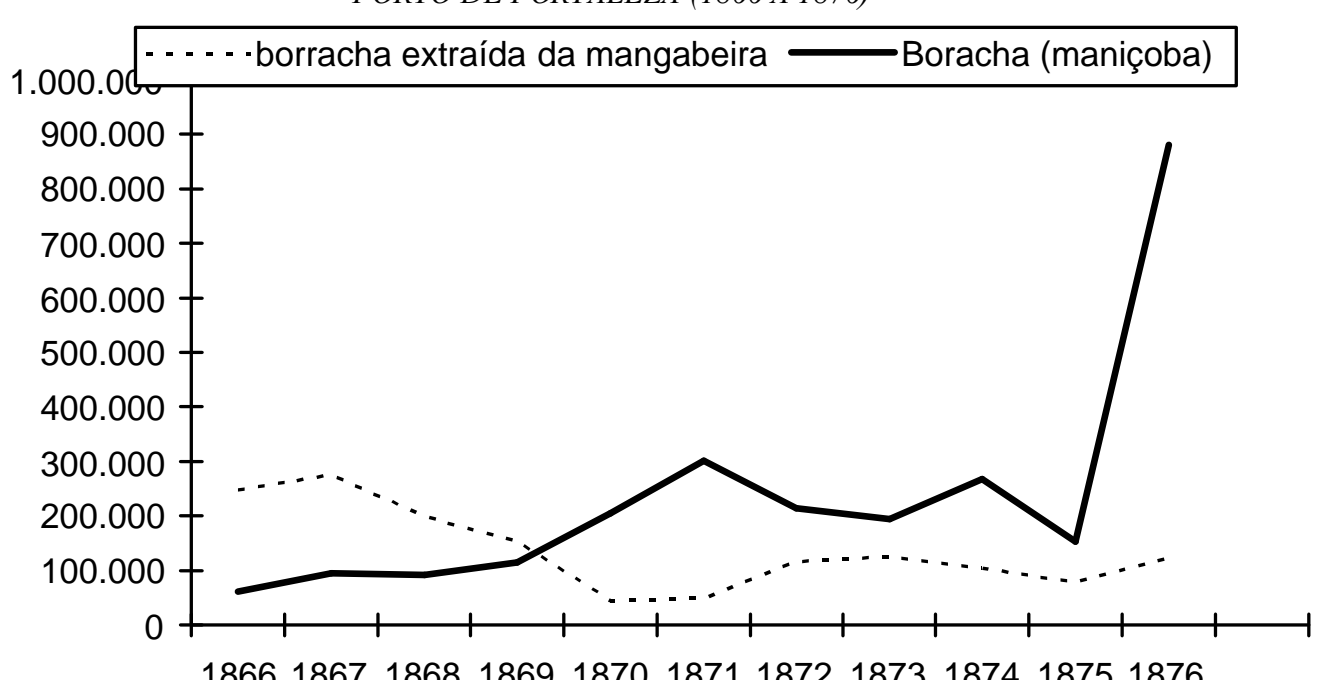

18661867186818691870187118721873187418751876

Fonte: POMPEU, Antonio. Ensaio Estatístico da Província do Ceará. Ed. Fac.sim. Fortaleza: Fundação Waldemar Alcântara, 1997.

O gráfico acima aponta uma produção crescente do produto com forte aumento em 1876, apesar disso, Rodolfo Teófilo disse que houve o decrescimento da exportação desses produtos, mas que isso se deu devido à seca e não ao pouco desenvolvimento dessa indústria, porquanto grande parte da cera de carnaúba é empregada no fabrico de velas. ${ }^{40}$ Contudo, ele não apresentou os dados relativos aos anos de secas, apesar disso, pode-se ponderar que essa indústria pouco foi afetada com a estiagem, tendo-se em vista que as carnaubeiras são árvores muitas bem adaptadas ao clima quente e seco do sertão. Além disso, havia mão de obra disponível caso se quisesse continuar com a sua extração.

A exportação da borracha feita da extração da cera da mangabeira e da maniçoba se manteve alta até 1876 . Se a indústria extrativa se baseava no aproveitamento econômico de produtos retirados de uma natureza adaptada ao clima do sertão, e por isso pouco afetada pelas estiagens. Assim como a exportação da borracha extraída da maniçoba e da mangabeira era alta até 1876 e se no ano seguinte houve queda da produção, isso não ocorreu por causa da 
situação climática, mas em razão da falta de mão de obra disponível. Quanto à produção agrícola. Entretanto, assim como a maniçoba os diversos produtos agrícolas cearense apresentaram alta produção no primeiro ano da chamada "grande seca".
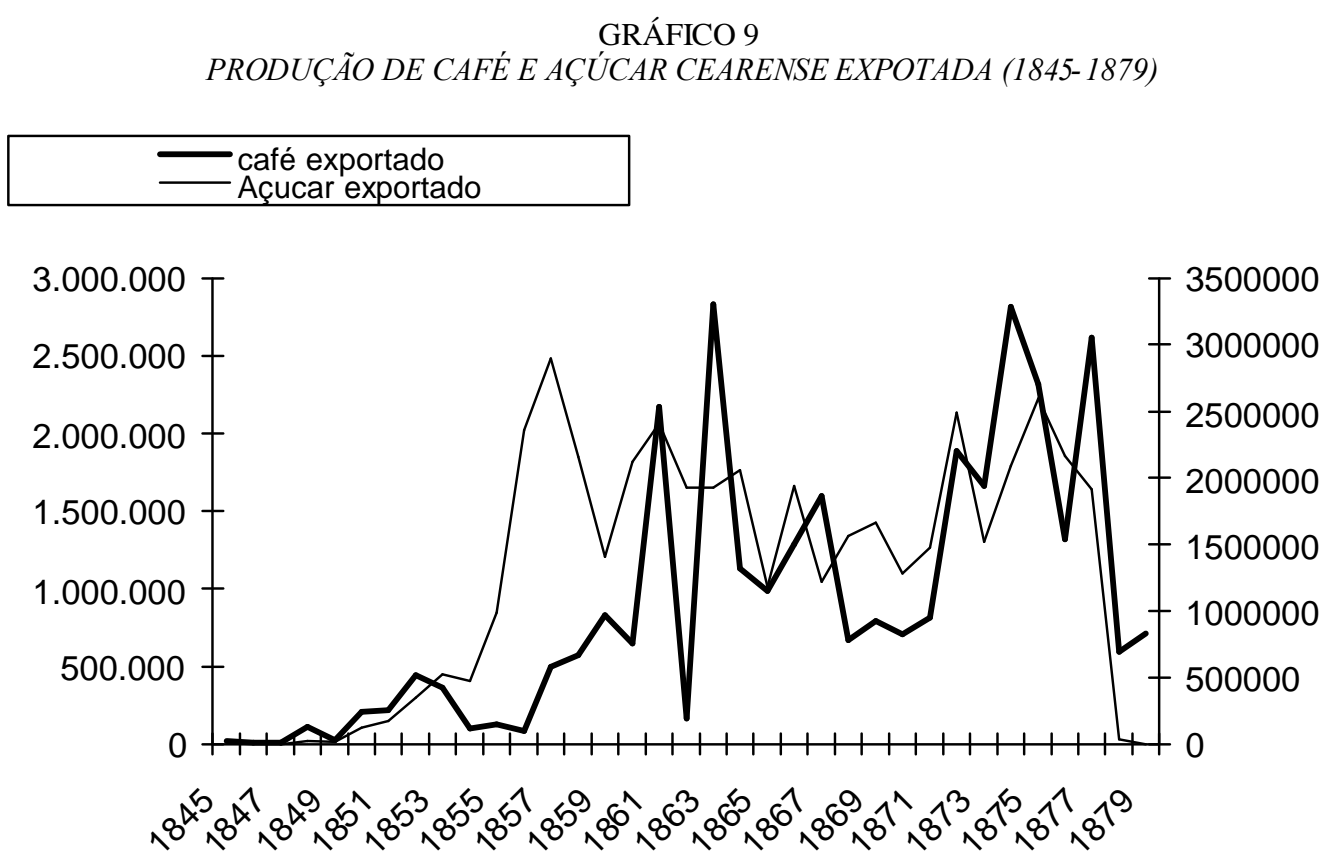

Fonte: TEÓFILO, Rodolfo. História das Secas no Ceará. (1877-79). Rio de Janeiro: Imprensa Inglesa, 1922, p.

Os principais produtos agrícolas da economia cearense foram: o algodão, o açúcar e o café. Desses três produtos, dois mantiveram o nível de exportação até o final de 1877: o café e o açúcar. O motivo principal para a manutenção da lavoura de açúcar e café era que como observou Celso Furtado a “economia exportadora nordestina, surgida na primeira metade do século XVI, centrou-se nas terras úmidas do litoral" ${ }^{41}$ Com isso, o processo migratório do sertão para o litoral não afetou grandemente essas culturas, mesmo o café produzido mais para dentro da província como na Serra da Aratanha, Maranguape, Uruburetama, Meruoca, Serra Grande e Araripe, mas, sobretudo na Serra de Baturité, como destacou Pedro Airton, cuja introdução no século XIX,

${ }^{41}$ FURTADO, Celso. A Fantasia Desfeita. Rio de Janeiro: Paz e Terra, 1989, p.16. 
tornou sua produção mais significativa. ${ }^{42}$ Entretanto, para o Ceará não é possível como afirmou Raimundo Girão "falar numa aristocracia do café como a do Rio de Janeiro e de São Paulo". ${ }^{43}$ Apesar disso, ele destaca uma espécie de pequena nobreza dos cafezais baturiteenses, de famílias ricas, com hábitos, costumes apurados formando um grupo de saliente projeção social, do qual saíram muitos homens ilustres.

GRÁFICO 10

PRODUÇÃO AÇUCAREIRA E CAFEEIRA CEARENSE DURANTE A SECA DE 1877-79.

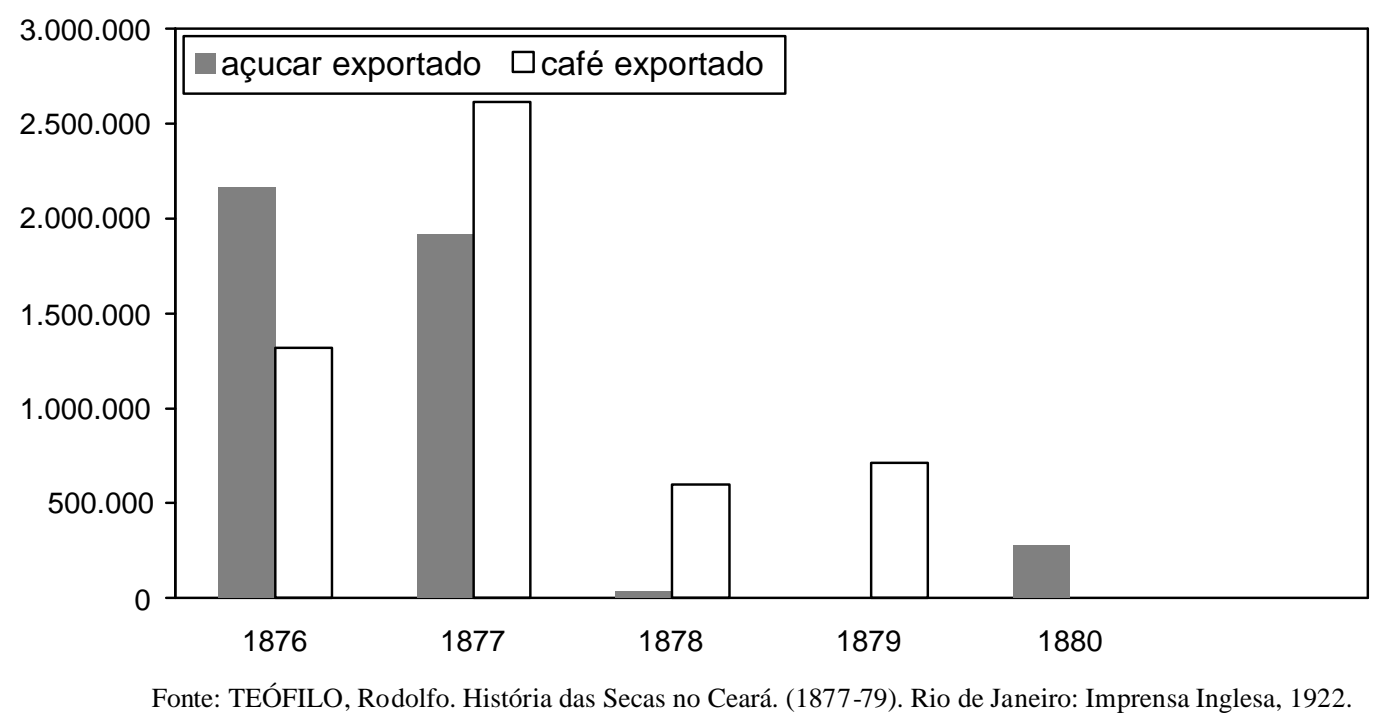

A lavoura da cana de açúcar e a de café foram as que menos sentiram o impacto da seca no seu primeiro ano. Observe-se que no caso do café em relação a 1876 houve aumento da exportação. Esses dois produtos se localizavam em áreas de destinos da mão de obra migrante como as serras onde se localizava a produção cafeeira e o litoral onde ficavam as plantações de cana de açúcar. A produção de açúcar e rapadura tanto para a exportação como para o consumo local não foi afetava pelo abandono dos domicílios e dos pequenos engenhos ou moendas utilizadas pelos sertanejos. Assim como o café cultivado nos pés de

${ }^{42}$ LIMA, Pedro Airton Queirós. O café na província do Ceará. 4 ed. Fortaleza: Fundação Demócrito Rocha, 1995, p.100.

${ }^{43}$ GIRÃO, Raimundo. História Econômica do Ceará. Fortaleza: Ed. Instituto do Ceará, 1947, p.371-372. 
serras onde o clima não foi tão afetado pela estiagem o açúcar era produzido no litoral. No setor açucareiro durante o primeiro ano da seca (1877) a produção se manteve alta em comparação com o ano anterior. É como se do ponto de vista econômico o ano de 1877 tivesse sido de normalidade.

Se havia abundância de mão de obra para a atividade açucareira e cafeeira porque esses setores foram atingidos nos anos seguintes de 78 e 79 ? Entre as explicações mais viáveis seria o receio por parte dos fazendeiros em produzir essas mercadorias devido à insegurança que havia em transportá-las até o porto de Fortaleza, pois os retirantes poderiam atacar as carroças já que ainda não havia a estrada de ferro de Baturité e invadir os armazéns das fazendas para roubar sacas de café e açúcar. Os saques e as ações de massa eram como observou Frederico de Castro Neves um problema sério, ainda mais porque os saques eram legitimados culturalmente. ${ }^{44}$ Entretanto, uma outra explicação se esboça mais viável: essas plantations exportadoras se voltaram para o mercado local, pois houve da parte do governo a necessidade de comprar alimentos como feijão, farinha, arroz, milho, carne e bacalhau.

Com isso, ao que parece ficou mais interessante nos anos de $1878 \mathrm{e}$ 1879 cultivar gêneros de primeira necessidade para abastecer o mercado local do que produzir para exportar. A plantation assumiu essa tarefa em razão do pequeno roceiro não ter suportado a tendência migratória na direção dos socorros públicos de 1877. Nesse sentido, Geraldo Nobre parece está correto ao afirmar que com a seca houve afluxo considerável de pessoas para a serra de Baturité, por ali possuírem propriedades ou parentela, ou por divisarem perspectivas mais tranqüilizadoras no tocante aos efeitos da calamidade, quase todas com alguma

\footnotetext{
${ }^{44}$ NEVES, Frederico de Castro. A Multidão e a História: saques e outras ações de massas no Ceará. Rio de Janeiro: Relume-Dumará; Fortaleza - ce: Secretaria de Cultura e Desporto, 2000, p.224,
} 
economia que procuraram aplicar em atividades rentáveis, "e nenhuma, naquela ocasião, seria preferível ao comércio de gêneros, repassados ao governo para distribuição aos retirantes pobres". ${ }^{45}$

O presidente Caetano Estelita em 1877 considerando a importância do comércio diante da necessidade de abastecimento de enormes massas populacionais deslocadas do interior do Ceará e de outras províncias convocou "uma conferência a que assistiram os mais distintos negociantes desta praça, os quais firmaram as bases de um acordo particular para o fim de abastecer o mercado de gêneros de primeira necessidade e vendê-los a população e ao próprio governo, quando este houvesse mister, mediante preços justos e razoáveis. ${ }^{46} \mathrm{Com}$ isso, comerciantes e produtores vão estar voltados ao abastecimento do mercado interno, sobretudo no ano de 1878 , quando a plantation se voltou para o mercado interno. Passou a haver uma disputa pelo mercado de fornecimento de gêneros alimentícios à população desvalida. Contudo, era o governo imperial quem comprava os víveres do Rio de Janeiro, Bahia, Pernambuco e das províncias do Sul e os enviava ao Ceará, sendo comprados nos mercados de Fortaleza e do Aracati apenas os "gêneros de que algumas vezes há falta". ${ }^{47}$

Entretanto, o presidente João José Ferreira de Aguiar descumpriu o acordo particular feito por Estelita com os principais comerciantes de Fortaleza para que estes abastecessem com víveres a população desvalida. O fato é que durante a administração Aguiar os gêneros do governo eram cada vez mais importados de outras províncias, embora este para se eximir das acusações dos

${ }^{45}$ NOBRE, Geraldo da Silva. O processo Histórico de Industrialização do Ceará. Fortaleza: SENAI/DR-CE. Coordenadoria de Divulgação, 1989, p.142.

${ }_{46}$ APEC - Fala com que o desembargador Caetano Estelita Cavalcante Pessoa presidente da província do Ceará abriu a $2^{\mathrm{a}}$ sessão da $23^{\mathrm{a}}$ legislatura, da respectiva assembléia, no dia 2 de julho de 1877, tipografia do Pedro II, p.37.

${ }^{47}$ APEC - Relatório com que o Conselheiro João José Ferreira de Aguiar passou a administração da província do Ceará a Paulino Nogueira Borges da Fonseca, 3 vice-presidente da mesma província, no dia 22 de fevereiro de 1878, p.10 
comerciantes afirmava que, que a forma de abastecimento empregada era um crime de "lesa-prosperidade contra o comércio do Ceará". ${ }^{48}$ E, por sua vez afirmava que por sua ordem e durante a sua administração, "somente foram comprados em outras províncias alguns cereais para sementes”. Porém, observa que se estivesse ao seu alcance impedir que o governo provesse a província de víveres, pela maneira que vinha fazendo ele não tentaria porque considerava o comércio interno insuficiente para realizar esse suprimento. Com isso, ele entrava em atrito com os interesses de uma pequena elite de comerciantes e produtores que disputavam o monopólio do abastecimento dos socorros públicos. Aguiar considerava que a ausência da interferência do governo imperial no abastecimento "seria uma ameaça à vida dos desvalidos e exporia a capital cearense à desordem e à anarquia”. 49

Porém, Rodolfo Teófilo contradiz o presidente Aguiar e confirma a possibilidade do comércio local em abastecer com gêneros os retirantes. "Os gêneros eram antes quase todos comprados ao comércio desta praça e por preços razoáveis; o novo presidente acabou com isso, por entender mais conveniente efetuar as compras no Recife e Rio de Janeiro, permitindo-as na praça da Fortaleza em casos desesperados". 50

Entretanto, quando assumiu o cargo o presidente José Júlio ele diferente do presidente anterior tomou o partido dos comerciantes da praça de Fortaleza. Considerou que nas circunstâncias da seca "só havia uma tábua de salvação para o comercio do Ceará, e era permitir-lhe concorrer para o

\footnotetext{
${ }^{48}$ APEC - Relatório com que o Conselheiro João José Ferreira de Aguiar passou a administração da província do Ceará ao Exmo sr dr Paulino Nogueira Borges da Fonseca, 3 vice-presidente da mesma província, no dia 22 de fevereiro de 1878, p.11.

${ }^{49}$ APEC - Relatório com que o Conselheiro João José Ferreira de Aguiar passou a administração da província do Ceará ao Exmo sr dr Paulino Nogueira Borges da Fonseca, 3 vice-presidente da mesma província, no dia 22 de fevereiro de 1878, p.11-12.

50 TEÓFILO, Rodolfo. História das Secas no Ceará (1877-1879). Rio de Janeiro: Imprensa Inglesa, 1922, p.128.
} 
fornecimento dos gêneros alimentícios, destinados a socorros públicos, única espécie de negociação possível no momento, e capaz de dar-lhe vida e força para atravessar a crise". ${ }^{51}$ De acordo com o presidente "A concorrência aberta para os fornecimentos, de que precisa o governo, ao mesmo tempo em que auxilia o comercio da província, facilita o abastecimento dos depósitos e evita prejuízos resultantes de avarias e despesas de desembarque, além de baratear os preços". 52

A entrega do fornecimento dos socorros públicos nas mãos dos comerciantes de Fortaleza implicava numa grande responsabilidade, mas também numa grande oportunidade de lucros exorbitantes. Contudo, como assinala José Júlio o abastecimento não com gêneros vindos de fora, não haveria desembarque de mercadorias, portanto o setor produtivo da província teria que atuar para fornecer víveres. Isso explicaria que setores relacionados a plantation como o açúcar e o café passaram então a utilizar suas terras para o cultivo de lavouras de subsistência. Os desembarques não cessaram ou porque outras províncias enviavam donativos ou porque o governo do Império continuasse comprando de outras províncias, entretanto, no governo do presidente José Júlio o peso das compras de gêneros de outras províncias caiu, pois o monopólio da praça mercantil de Fortaleza sobre o abastecimento se tornou dominante.

De fato não eram todas as localidades do Ceará que sofriam os efeitos das secas. Observou o presidente João José Ferreira de Aguiar, no seu relatório de 1878, que "somente nas serras mais frescas, tais como Ibiapaba, Meruoca, Baturité, Pacatuba e Maranguape, e nos vales do Cariri e Ipú, conservou-se alguma vegetação". Segundo ele essas regiões ficaram “a salvo das secas pela

\footnotetext{
51 APEC - Fala com que o José Júlio de Albuquerque Barros presidente da província do Ceará abriu a 1 sessão da 24 legislatura da Assembléia Provincial, no dia 1 de novembro de 1878. Fortaleza: Tipografia Brasileira, 1879. p.22-23.

52 Ibid, p. 23.
} 
uberdade do solo". Porém, assinala que os seus habitantes também sofreram com a seca porque os povos do alto sertão, ao sentirem o aguilhão da fome ou a carência de recursos para alimentarem os seus animais, afluíram "para aquelas paragens, causando danos irreparáveis à lavoura alheia". ${ }^{53}$

Em 1878 de acordo com o presidente Aguiar não houve colheita de legumes e cereais, nem de mandioca. O cultivo do café se limitou a serra de Baturité, e teria sido pequena no ano anterior. Nesse ponto Aguiar se enganou porque as estatísticas indicam aumento do café exportado em 1877 em relação a 1876. Isso ocorreu porque praticamente toda a produção era realizada na região da serra de Baturité. Quantos aos produtos sacarinos estes continuaram nas serras de Baturité, Ibiapaba e no Cariri, em quantidade cada vez mais decrescente. Embora no primeiro ano da seca a queda na exportação tenha sido pequena. Aguiar subestimou a lavoura cearense para justiçar suas compras de gêneros em outras praças comerciais ao afirmar que o açúcar em 78 foi "apenas suficiente para o consumo local" ${ }^{54} \mathrm{O}$ único ano em que não se exportou açúcar foi em 79 , mas nos demais houve exportação de café e de açúcar.

Dos produtos naturais, os únicos que são aproveitados na província, a goma elástica e a cera de carnaúba, também decresceram pela pobreza da seiva da maniçoba e da mangabeira, de que se extraem a primeira daquelas substancias, e pela destruição e perecimento dos carnaubais, devorados pela seca e pelos famintos, que se tem alimentado com o palmito e com a massa farinácea do tronco. Dos produtos minerais, os únicos que são aproveitados na província, a cal e o sal, pouco tem sido utilizados, por falta de obras a que se aplique o primeiro,

\footnotetext{
${ }^{53}$ APEC - Fala do presidente da província do Ceará José Júlio de Albuquerque Barros. $1^{\text {a }}$ sessão da $24^{\mathrm{a}}$ legislatura da Assembléia Provincial no dia $1^{\mathrm{o}}$ de novembro de 1879, p.21.

${ }^{54}$ Ibid.
} 
pela superabundância do último. ${ }^{55}$

GRAFICO 11

EXPORTAÇÃO DE ALGODÃO CEARENSE (1845 - 1876)

-Produção algodoeira

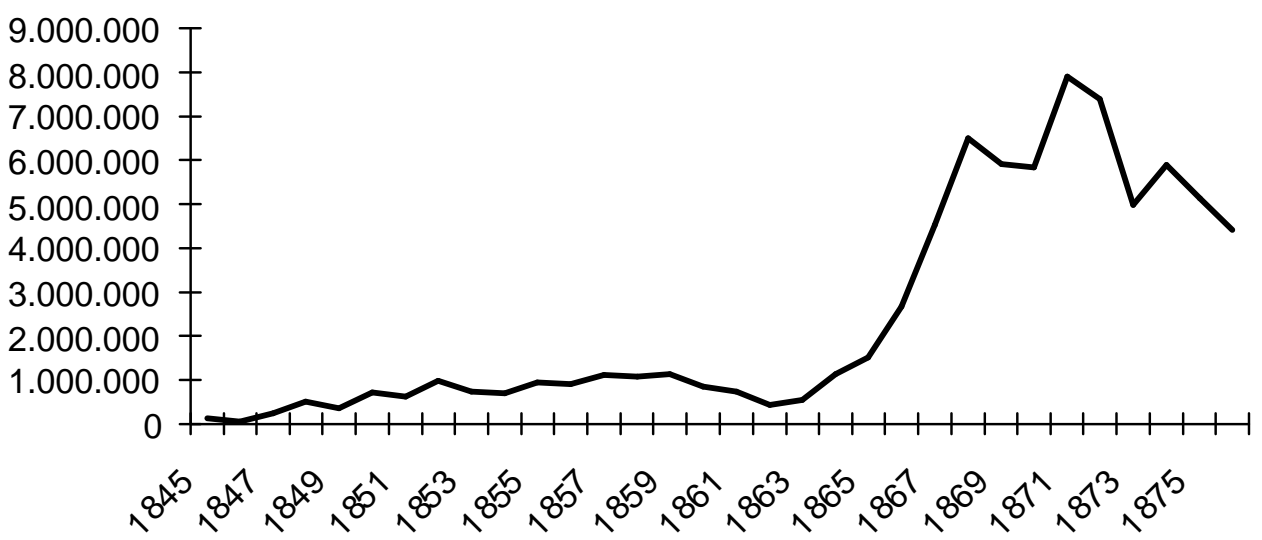

Fonte: TEÓFILO, Rodolfo. História das Secas no Ceará (1877-1879). Rio de Janeiro: Imprensa Inglesa, 1922, p. 20.

Quanto ao algodão, não se deve atribuir o seu declínio à seca, pois em 1871, após terminar a Guerra de Secessão os americanos recuperaram a produção e sua posição no mercado consumidor europeu. Mas, considerando-se que a Europa continuasse demandando o algodão brasileiro durante a seca haveria uma queda na sua produção decorrente do abandono progressivo das lavouras, porque diferente do açúcar e do café o algodão era cultivado no sertão, como observou José Bozarcchiello da Silva, onde havia mais regularidade climática, pois quanto mais se aproximava do litoral a incidência de chuvas repentinas poderia danificar a flor desabrochada do algodão. ${ }^{56}$

GRÁFICO 12

PRODUÇÃO PASTORIL CEARENSE ( 1845 - 1879)

\footnotetext{
${ }^{55}$ APEC - Fala do presidente da província do Ceará José Júlio de Albuquerque Barros. $1^{\mathrm{a}}$ sessão da $24^{\mathrm{a}}$ legislatura da Assembléia Provincial no dia $1^{\circ}$ de novembro de 1878, p.21.

56 SILVA, José Borzacchiello da. O algodão na organização do Espaço. In: SOUZA, Simone. História do Ceará. $4^{\mathrm{a}}$ ed. Fortaleza: Fundação Demócrito Rocha, 1995, p.82.
} 


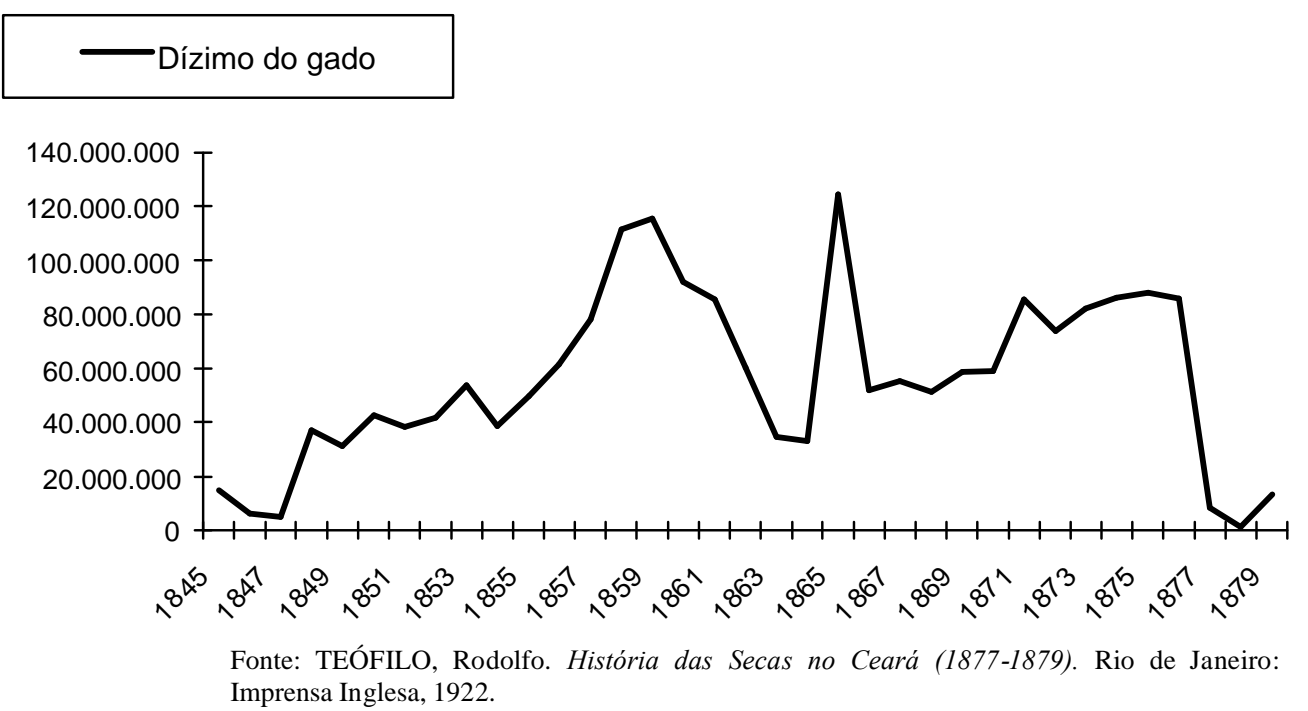

Considerando-se o dízimo cobrado sobre a produção pastoril podemos observar que esse setor, apesar de ser muito irregular apresentou um aumento em 1877. Isso ocorreu porque os criadores procuravam se livra dos rebanhos temendo a seca. A indústria pastoril no Ceará funcionava pelo sistema semi-selvagem, quase toda entregue às forças da natureza, às epizootias, mas, sobretudo às secas. Apesar disso, a indústria pastoril se desenvolveu desde a seca de 1845. Para avaliarmos seu desenvolvimento vamos considerar o imposto do dízimo que correspondia, como avaliou o senador Pompeu, a 4\% da produção. Essa atividade vai sentir fortemente a queda na produção em 1878-79 porque os rebanhos foram vendidos ou abatidos.

A pecuária cearense apresentou variações bruscas na sua produtividade. Isso não se deveu à seca, pois como podemos observar o período que corresponde de 1845 a 1876 foi de normalidade. Porém, o sistema semiselvagem, as doenças e a falta de cuidados com a saúde dos animais, como observou o Barão de Capanema, provocou quedas bruscas na produção. A seca de 1877 atingiu duramente esta atividade, devido à escassez não de água, mas de pasto para alimentar os animais. Como o gado era criado solto os pecuaristas 
cearenses não cogitavam num sistema de irrigação de pastos, e com isso, os animais terminavam morrendo de fome, abandonados pelas caatingas. Essa será uma surpreendente constatação feita pelo Barão de Capanema, em 1861, na época da Comissão Cientifica de Exploração, como veremos no capítulo 5.

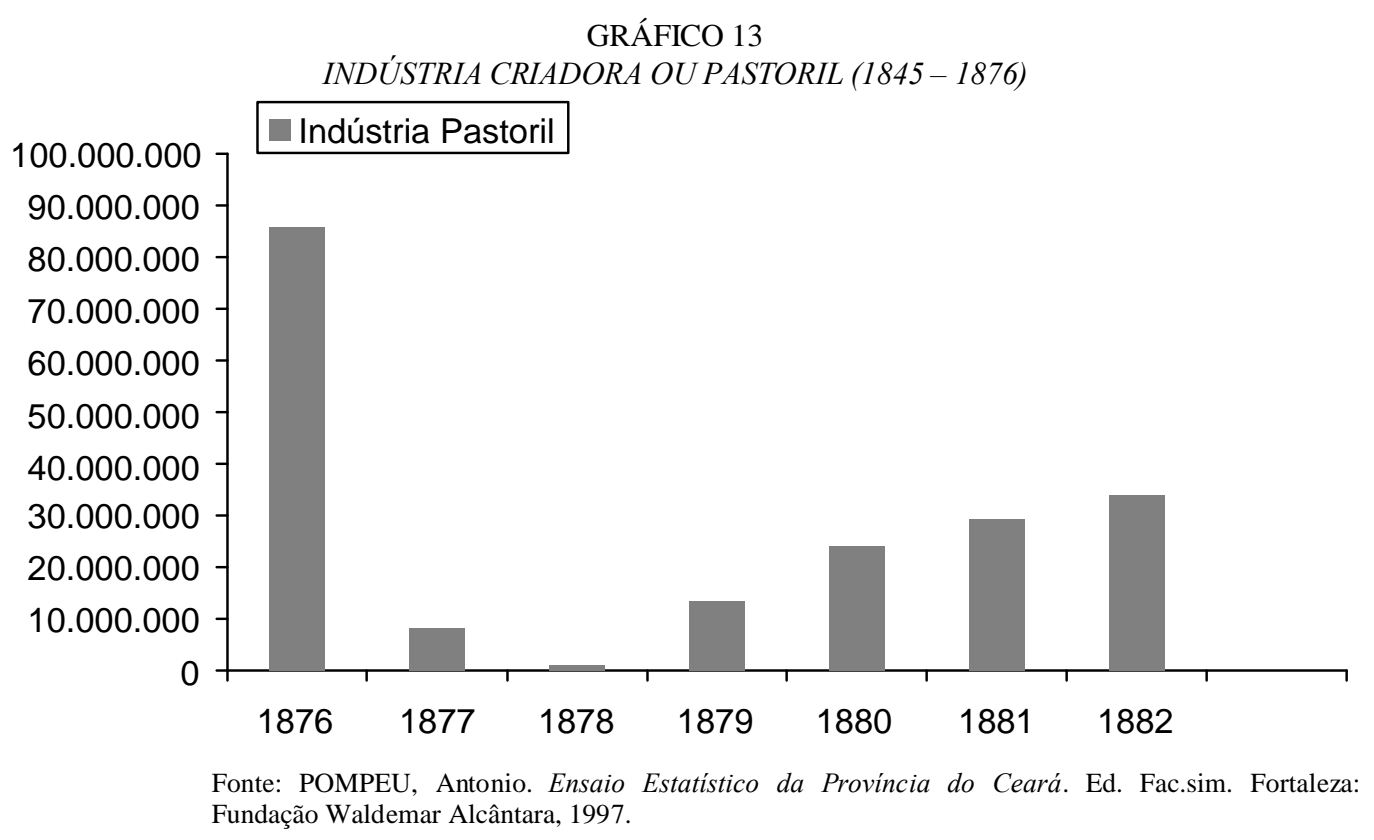

Apesar da queda na produção em 1877 e 1878, observamos que essa indústria apresentou uma recuperação no terceiro ano da seca e manteve de modo processual essa recuperação. Nos vários setores da economia cearense observamos que o impacto será progressivo na medida em que a população abandona o campo em direção aos socorros públicos no litoral. Se tivéssemos dados relativos à exportação do algodão veríamos, provavelmente, que seus números cairiam, pois havia no Ceará o chamado binômio gado-algodão. A ocupação do sertão cearense se deu com a conjugação desses dois produtos de exportação, pois os rebanhos eram cada vez mais forçados a adentrar o interior devido a expansão da lavoura açucareira e o algodão por sua vez precisava fugir das irregularidades climáticas do litoral. 
Quanto ao setor fabril os principais artigos eram os couros secos e salgados, solas, couros miúdos, carne charqueada, queijos, sabão, velas de carnaúba, obras de palha, tecidos grossos de algodão, redes, açúcar refinado, vinho de caju, cigarros, bordados, crivos etc. Outrora se preparava e exportava grande quantidade de carne seca, geralmente conhecida no norte do Brasil pelo nome de carne do Ceará. Disse o major João Brígido que em Aracati, antes da seca de 1792, charqueavam-se anualmente de 20 a 25 mil bois, mas no início do século XX essa indústria estava quase extinta. Os couros miúdos preparados eram consumidos na própria província em imensa quantidade e pouco se exportam. Mas, os couros graúdos secos e salgados eram exportados para o mercado estrangeiro e para o Recife e o Maranhão. Considerando-se que havia uma relação estreita entre a pecuária e a indústria fabril, tendo em vista que o principal produto dessa indústria eram os couros secos ou salgados, com a redução dos rebanhos durante as seca havia, é claro, uma redução nas exportações. No primeiro ano da seca deve ter aumentado a exportação de couros.

A produção de queijos na província quase toda se destinava ao consumo local. Já a indústria calçadista exportava do porto de Fortaleza e do Aracati um grande número de calçados e chapéus de palhas de carnaúba, tendo estes um consumo interno considerável. Na capital cearense havia fábricas de sabão, uma de tecidos (a fábrica Progresso), pertencente à família do senador Pompeu, fundições de ferro, várias fábricas de cigarros, de charutos, de chapéus, refinações de açúcar, fábricas de vinho de caju, e de outras frutas, produtos farmacêuticos, que começaram a ser exportados em alguma escala. Já no interior se faziam tecidos grossos de algodão para vestimentas de escravos e homens do campo e até para o consumo do Piauí. Em vários municípios se bordavam e 
teciam redes de dormir. Para o Rio de Janeiro e o Pará se exportavam grandes quantidades de rendas e crivos, doce de goiaba da serra da Aratanha e Maranguape, grande quantidade de rapaduras de laranja de Baturité.

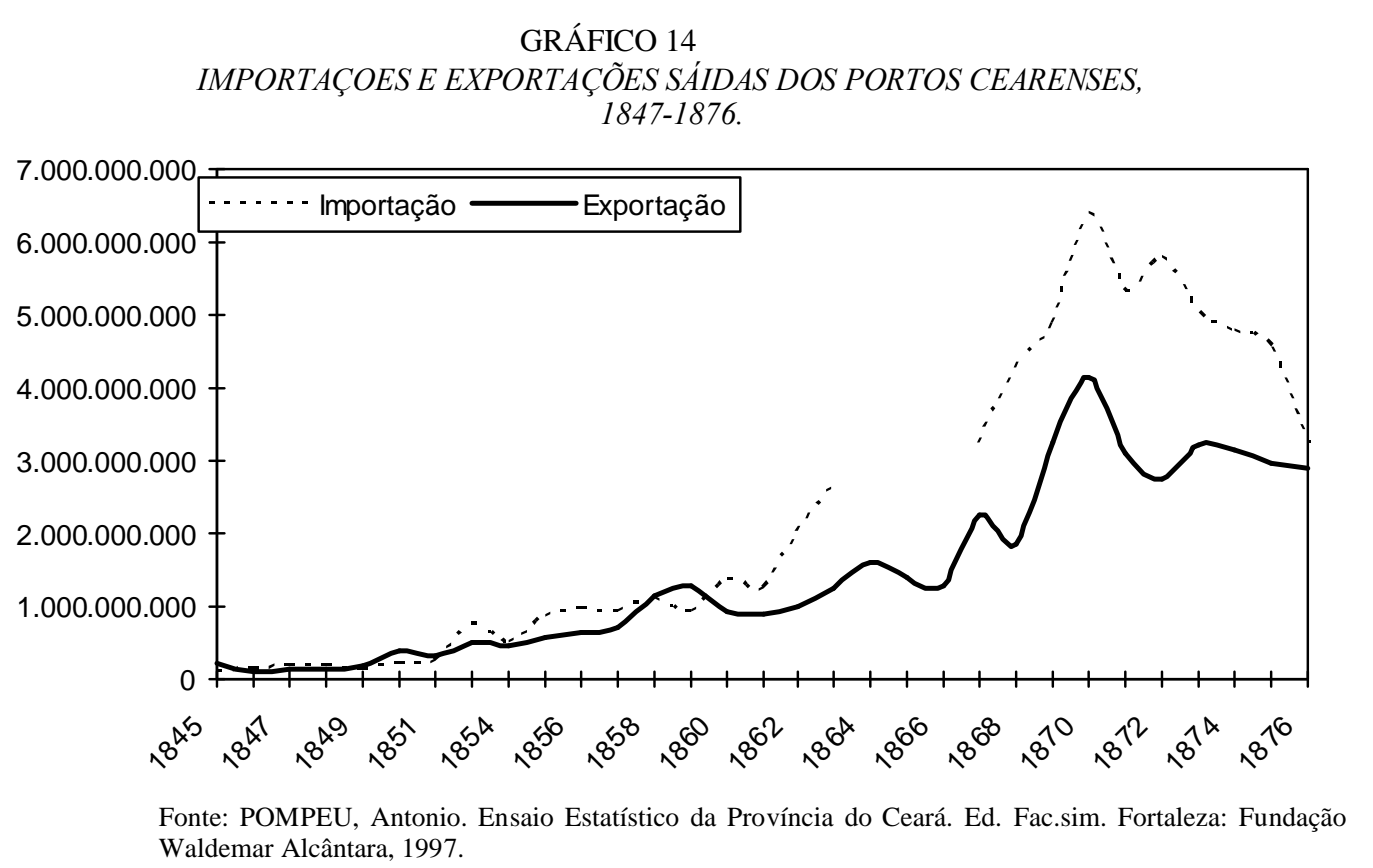

A balança comercial cearense foi deficitária praticamente em toda a segunda metade do século XIX. Ou seja, o comércio cearense dependeu das mercadorias importadas para abastecer a demanda interna. Também esse déficit se deve a uma atividade produtiva restrita a poucos produtos, levando a uma demanda enorme de produtos finos vindos de fora como pólvora, rapé, cigarros e charutos. Essa diferença se explica devido ao fato do Ceará exportar matérias primas como algodão, café, açúcar, couros, goma elástica, solas, ceras de carnaúba, raízes de carrapichos, crinas, penas de emas, peles, sebos, ossos e vassouras e importava produtos industrializados de valor muito maior. 


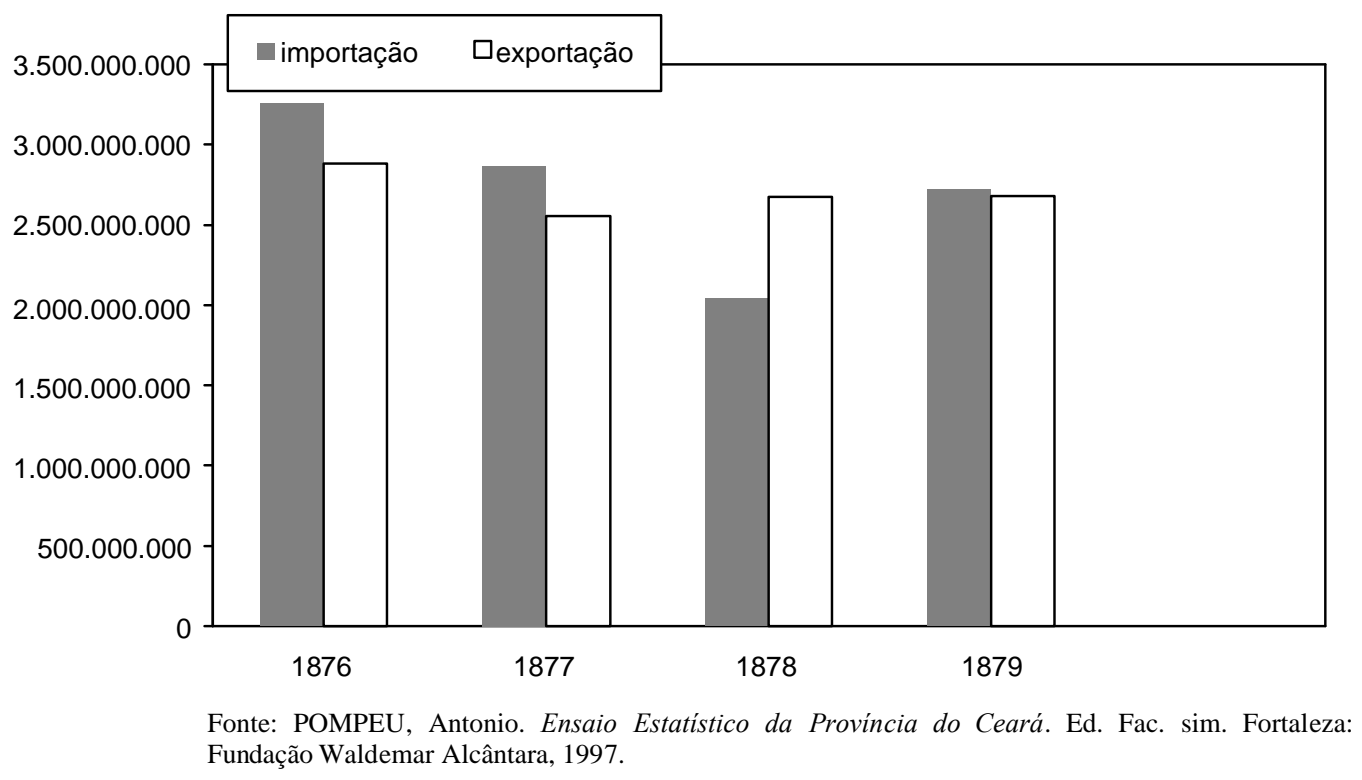

Mesmo durante a seca de 1877-79 a atividade comercial cearense se manteve em relação aos períodos anteriores havendo um aumento da atividade exportadora em relação à importação. Como era possível o Ceará exportar mercadorias num período em que a atividade econômica devia estar paralisada? É óbvio que houve atividade comercial e no segundo ano de seca (1878) as exportações se tornam maiores que as importações. Ocorreu que a população que comprava as mercadorias importadas passou a consumi-las de graça por meio dos socorros públicos. Essa queda do mercado consumidor se deve ao advento da seca. Rodolfo Teófilo não considerou que apesar do crescimento da atividade econômica de 1845 a 1876 houve nesse período uma relação deficitária entre a receita e a despesa, devido ao clientelismo praticado pelos gestores. 


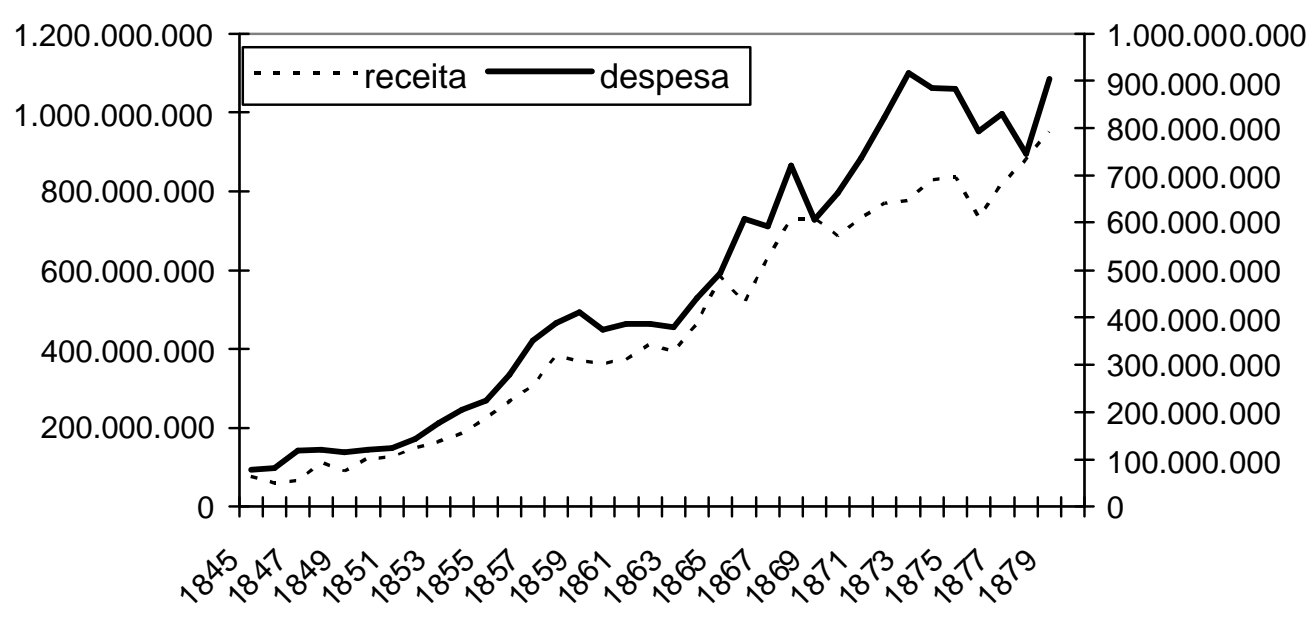

Fonte: TEÓFILO, Rodolfo. História das Secas no Ceará (1877-1879). Rio de Janeiro: Imprensa Inglesa, 1922.

Se compararmos as despesas com as receitas acumuladas, de 1845 a 1876, poderemos constatar que o estado foi quase sempre deficitário. Entretanto, isso não se deveu a balança comercial, pois mesmo que a importação tenha sido superior a exportação o governo recolhia imposto e aumentava a receita. Parte importante desse estado das finanças públicas se deve ao clientelismo, ou seja, ao emprego de partidários no serviço público aumentando a folha de pagamentos. Contudo, ao compararmos a receita e a despesa nos três anos da chamada "grande seca", podemos observar que no primeiro ano a receita foi quase igual à despesa, no segundo, quando a seca foi considerada mais grave a receita superou a despesa e no terceiro ano se manteve superior. Essa melhoria da receita em relação à despesa ocorreu também porque o governo teve um aumento de recursos nos cofres proveniente da chamada verba dos socorros públicos. Com isso, houve uma queda nos gastos públicos realizados pelo governo do Ceará com recursos do Tesouro Provincial que passaram algumas dessas despesas a serem feitas com recursos destinados aos socorros públicos vindos do governo imperial. 


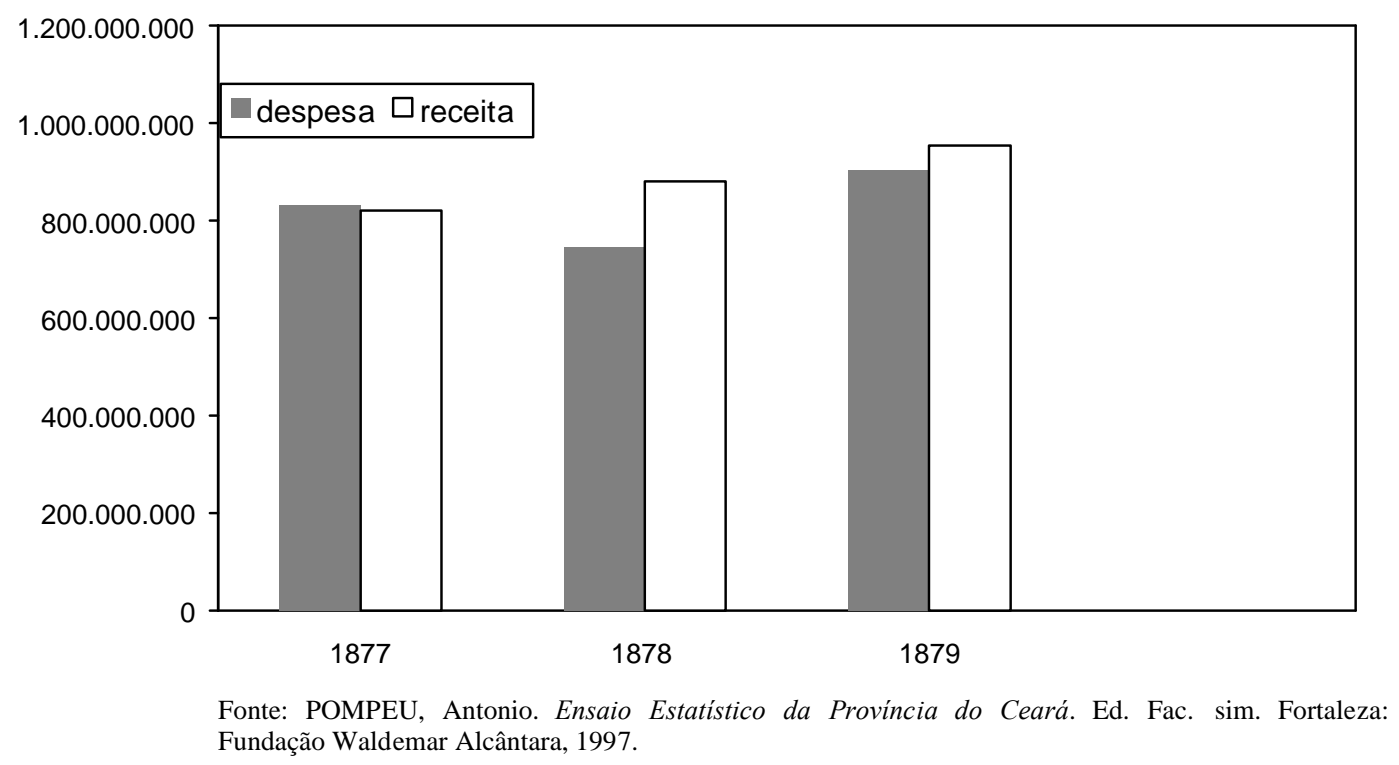

Observou o presidente Caetano Estelita em 1877 que antes da seca se manifestar, a província estava onerada com uma dívida de 200:000\$000 (duzentos contos de réis), e o seu administrador, o presidente, era obrigado a contrair novos empréstimos para as despesas mais urgentes, "por não existir um real no cofre". 57 Essa situação que a província atravessava, prolongava-se há alguns anos, obrigava sempre o próximo governo a se endividar e á esse extremo foi levada, concluiu Estelita por não se ter prudentemente "guardado o equilíbrio entre a receita e despesa". 58

Em 1876, na administração do presidente Francisco de Farias Lemos, a receita orçada para o ano seguinte foi $818: 432 \$ 000$ e a despesa em: 866:013\$891. Se a receita orçada fosse uma realidade haveria um déficit de 47:581\$891. Porém, estava-se longe disso, pois a arrecadação feita até o final de maio de 1877 registrou 167: 618\$838 e, a arrecadação calculada para os sete meses restantes era de 366: $215 \$ 750$, com isso a receita total chegaria a 533:834\$588. Ora, como a receita orçada era de 818:432\$000 haveria uma

\footnotetext{
${ }^{57}$ APEC - Fala com que presidente da província do Ceará José Júlio de Albuquerque Barros. $1^{\text {a }}$ sessão da $24^{\mathrm{a}}$ legislatura da Assembléia Provincial no dia $1^{\circ}$ de novembro de 1878 , p.62.

58 APEC - Fala do presidente da província do Ceará Caetano Estelita Cavalcante Pessoa Presidente. $2^{\mathrm{a}}$ sessão da $23^{\mathrm{a}}$ legislatura, 02 de julho de 1877 , p. 28.
} 
diferença para menos da calculada de 284:597\$412. O governo do presidente Caetano Estelita temia que mesmo essa projeção negativa não se confirmasse com o agravamento da seca. ${ }^{59}$

Entretanto, Estelita ao se referir ao relatório deixado pelo presidente Francisco de Farias Lemos apresentou números diferentes dos deixados por este, como, por exemplo, ter dito que a projeção para o exercício financeiro de 1877 previa um saldo de 41: $645 \$ 459$ quando o governo anterior havia informado que haveria déficit. É difícil acreditar que ele tenha se enganado. Se ele não se enganou com os números, resta a explicação de que Estelita teria tentado mostrar que a seca fora a responsável pela crise financeira atravessada pela província.

Essa idéia se tornou corrente entre os presidentes que governaram o Ceará durante a oligarquia. Em 1896 o presidente coronel Bezerril Fontenele observou que "Os orçamentos do Ceará no regime do Império bem poucas vezes fecharam com saldos; a regra era o déficit". ${ }^{60}$ Entretanto, com o início da República o Ceará passou a ter as contas mais sob controle. Nos sete exercícios financeiros após 1889 o Estado acumulou um saldo de 1.827:132\$287. Para tentar conter a pressão dos parlamentares em utilizar os recursos do Tesouro Provincial o coronel alegou que "O Estado nada deve, é certo; mas acautelai-vos srs. Representantes do povo cearense: basta um período de seca como o de 1877-79, e as finanças do Ceará estarão arruinadas". ${ }^{61}$

Não obstante o acúmulo de déficits anuais na correlação entre a receita e despesa a província estava empenhada, pois devia ao Banco do Brasil 140:000\$000 réis provenientes de um empréstimo levantado de duzentos contos

\footnotetext{
59 Ibid.

${ }^{60}$ APEC - Mensagem do presidente do Estado do Ceará Coronel José Freire Bezerril. 5 $5^{\text {a Sessão }}$ Ordinária, da $1^{\mathrm{a}}$ legislatura. Fortaleza: Tipografia da República, 1896, p.14.

61 Ibid.
} 
de réis, amortizável em quotas anuais de vinte contos. ${ }^{62}$ Assim, os 200 contos, divididos em vinte anos geraram uma parcela de 10 contos, porém os juros exorbitantes obrigavam o governo a pagar 34: $200 \$ 000$ (trinta e quatro contos e duzentos mil réis), valor permanente na despesa orçada:

TABELA 3

ORÇAMENTO DA DESPESA PROVINCIAL DO CEARÁ PARA O ANO

DE 1877

\begin{tabular}{|c|c|}
\hline Resumo & Orçada para 1877 \\
\hline Representação provincial & $37: 740 \$ 000$ \\
\hline Secretaria do Governo & $43: 300 \$ 000$ \\
\hline Instrução Pública & $187: 305 \$ 666$ \\
\hline Biblioteca e Arquivo Público & $2: 580 \$ 000$ \\
\hline Museu Provincial & $663 \$ 000$ \\
\hline Culto Público & 14: $800 \$ 300$ \\
\hline Tesouraria provincial & $97: 403 \$ 333$ \\
\hline Aposentados & $38: 121 \$ 212$ \\
\hline Força Policial 9 & $221: 540 \$ 650$ \\
\hline Iluminação Pública & $50: 000 \$ 000$ \\
\hline Presos e cadeias & $63: 620 \$ 000$ \\
\hline Obras públicas & $35: 800 \$ 000$ \\
\hline Subvenções & $27: 500 \$ 000$ \\
\hline Divida provincial & $34: 200 \$ 000$ \\
\hline Diversas despesas eventuais & $11: 440 \$ 000$ \\
\hline Depósitos & ....................... \\
\hline Total & $866: 013 \$ 891$ \\
\hline
\end{tabular}

Observa-se ainda, que além dessa dívida longa havia despesas desproporcionais, porquanto se gastava 37:740\$00 contos com representação provincial, ou seja, dinheiro gasto com despesas de parlamentares, 47: 300 contos com a secretaria de governo e mais 97: $403 \$ 333$ contos com a Tesouraria Provincial. Esses três gastos com a burocracia do governo, somados, equivaliam quase a todo o orçamento para a educação e ou para a segurança pública. Considerando-se a despesa com a representação provincial 37:740\$00, o gasto era maior do que com as obras públicas (35:800\$000).

\footnotetext{
${ }^{62}$ APEC - Fala do desembargador Caetano Estelita Cavalcanti Pessoa. $2^{\mathrm{a}}$ sessão da $23^{\mathrm{a}}$ legislatura. Fortaleza: Tipografia Pedro II, 2 de julho de 1877, p.28.
} 
O crescimento populacional seria, dentre os índices escolhidos, o parâmetro para medirmos o impacto da seca de 1877-79 sobre a população cearense. No entanto, é difícil fazer comparações porque a população cearense cresceu consideravelmente a cada estiagem. Com isso, sob o ponto de vista demográfico a última seca foi sempre pior que as suas antecessoras. Assim, o dado populacional serve apenas para uma análise circunstancial, ou seja, para entendermos o impacto da seca sobre a população do Ceará apenas nos anos da dita "grande seca". Se não é adequado comparar a seca de 1877-79 com as suas antecessoras pela imprecisão dos dados e dos relatos dos memorialistas, pode-se, no entanto comparar esta seca com as suas sucessoras como a seca de 1888-89, 1894 e 1900.

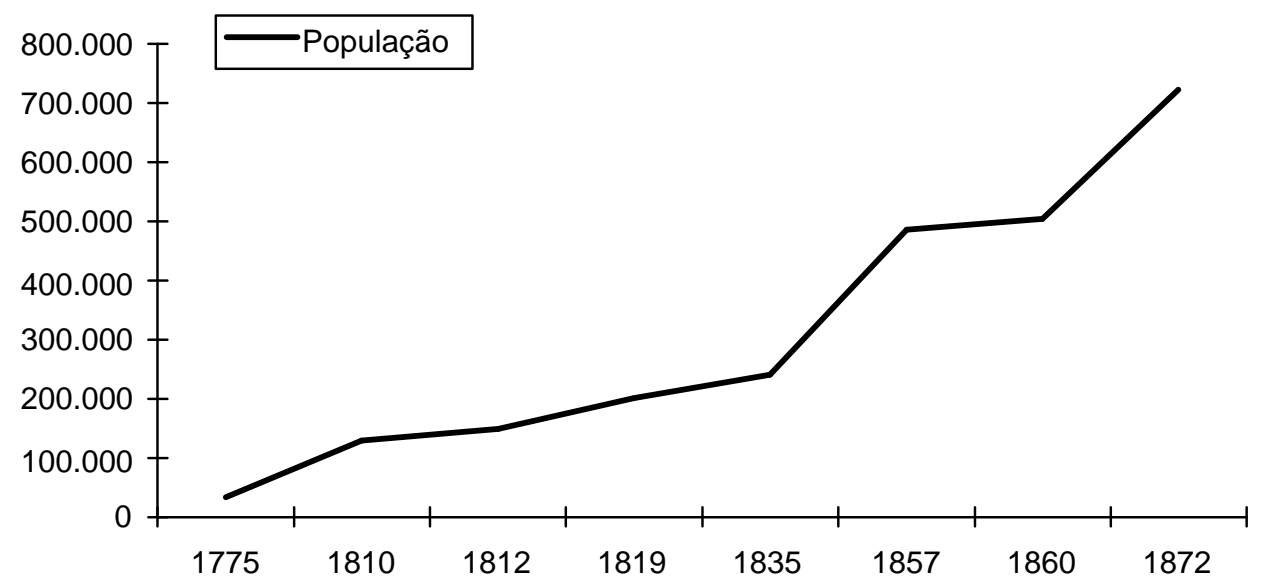

Fonte: POMPEU, Antonio. Ensaio Estatístico da Província do Ceará. Ed. Fac. sim. Fortaleza: Fundação Waldemar Alcântara, 1997.

A noção de que a seca de 1877-79 foi uma "grande seca" também não pode ser explicada, considerando-se que a população do Ceará manteve um índice de crescimento de 1775 até 1872. Nesse sentido, sob o ponto de vista demográfico, o impacto da estiagem de 1811 sobre a população foi menor que na seca de 1824-25. Seguindo esse raciocínio na estiagem de 1877-79 a população 
atingida foi maior que nos anos anteriores, sobretudo porque desde a seca de 1844-45 a população da província aumentou num ritmo ainda mais acelerado. Com isso, o crescimento da população não explica o impacto da estiagem de 1877-79, mas, a migração de enormes contingentes populacionais em direção às cidades litorâneas, que provocou um desequilíbrio demográfico entre os municípios e gerou todos os problemas sociais, alçando a seca à condição de calamidade política. Assim, de 1850 a 1905 houve uma inversão importante: a seca de calamidade natural se tornou calamidade política e a violência de calamidade política passou a ser uma calamidade natural.

$$
* * *
$$

O ano de 1877 representa um marco importante na história do Ceará: as secas se tornaram o acontecimento mais importante da província e a noção segundo a qual estas eram cíclicas se consolidou. Por outro lado, a violência foi relegada a um plano secundário. Considerando-se que esta era um gargalo social ao progresso econômico do lugar, seu recrudescimento significou o estancamento do crescimento econômico do estado. Mas, a questão mais importante é a contestação de que a seca de 1877 foi uma grande seca. $\mathrm{O}$ aumento populacional, mas, sobretudo o intenso processo migratório justifica essa assertiva. A questão, a saber, é porque a migração foi mais intensa nessa seca do que nas anteriores. 


\section{Capítulo 3 - Da agroexportação à atividade manufatureira: disparidades econômicas, 1840-1905.}

Como vimos no capítulo 2, a partir de 1877 as secas passaram a se sobrepor em importância à violência e às enchentes. Isso levou a uma diminuição da preocupação com o problema da falta de segurança no sertão como uma questão política e econômica, afetando o crescimento material da província e restabelecendo os atentados à segurança individual e à propriedade. Outro aspecto importante foi que ocorreu uma mudança do pensamento econômico acerca do modo como o Ceará deveria assentar seu desenvolvimento material.

Passou-se a desacreditar no potencial da agropecuária, devido aos estragos provocados pela "grande seca" e se tentou dar um salto para a atividade manufatureira por meio de uma política de incentivos à instalação de fábricas, fabriquetas e oficinas. Além disso, a seca passou a ser vista como um óbice ao desenvolvimento das províncias, que por isso, tornaram-se dependentes do governo central para progredirem. A conjugação desses fatores contribuiu para o processo crescente de disparidade entre o Norte e o Sul do país no século XIX.

\subsection{Agricultura, comércio e manufatura.}

A partir de 1877 a violência de calamidade política se tornou uma calamidade natural e a seca de calamidade natural passou a ser uma calamidade política. Isso teve como substrato a mudança no pensamento econômico dos governos provinciais em relação ao modo como a província deveria assentar seu 
progresso material. Entre 1836 e 1876 o Ceará baseou seu crescimento econômico no investimento na agricultura de exportação, pois se percebeu que isso expandia a própria agricultura, dinamizava o comércio e gerava os capitais necessários para a atividade manufatureira. De fato, esses três setores apresentaram crescimento até 1876 quando irrompeu a chamada "grande seca". Diante desse fato, as elites passaram a defender uma política de incentivo à atividade manufatureira, mudando o eixo do crescimento econômico da província.

Além disso, passou-se a defender que a escassez dos recursos naturais era um impeditivo ao progresso material do Ceará. Com isso, os presidentes de província ligados à oligarquia Pompeu Acióli reivindicavam, a cada seca, recursos para a construção de obras públicas como açudes e estradas de ferro. Com isso, o desenvolvimento das províncias do Norte ficou cada vez mais dependente dos recursos públicos provenientes do poder central. No entanto, a historiografia tradicional atribui o declínio econômico do Norte em relação ao Sul à decadência das lavouras tradicionais, como a cana de açúcar, o algodão e o tabaco.

Caio Prado Jr. destacou além desses fatores que contribuíram para acentuar as diferenças entre as duas regiões, o fato de no Sul ter se aclimatado “admiravelmente a cultura de um gênero que se tornaria no correr do séc. XIX de particular importância comercial: o café”. ${ }^{1}$ Assim, na segunda metade se chegou a "uma inversão completa de posições: o Norte, estacionário, senão decadente; o Sul, em primeiro lugar, em pleno florescimento". ${ }^{2}$ Houve, com isso, uma redistribuição das regiões produtivas do país na qual o centro-sul se

\footnotetext{
${ }^{1}$ PRADO JR., Caio. História Econômica do Brasil. São Paulo: Brasiliense, 2008, p.159.

${ }^{2}$ Ibid., p. 157.
} 
destacou na atração de capitais estrangeiros, sobretudo o inglês. ${ }^{3}$

Nesse sentido, Virgílio Noya Pinto, considerou que a decadência da agricultura tradicional brasileira foi determinada pela situação econômica internacional e pela "impotência interna do Brasil em se reestruturar, devido à falta de capitais, ausência de renovação das técnicas, carência de mão de obra" ${ }^{4}$, o que segundo ele teria neutralizado, em grande parte "a região Norte e Nordeste do Brasil". 5 Somou-se a isso, no seu entender, a instalação da Corte no Rio de Janeiro e a cultura do café que se espraiando pelo Sul inverteram "o panorama brasileiro fixando no Sul o novo eixo econômico". ${ }^{6}$

É inegável a importância do cultivo do café para a economia do Centro-Sul. No entanto, ao longo da primeira metade do século XIX não houve impotência do Ceará em se reestruturar nem ocorreu a decadência da lavoura tradicional. Ao contrário disso, em 1836 o presidente da província José Martiniano de Alencar sancionou uma lei que autorizava o governo da província a dar ordem à compra de modelos e máquinas cujo emprego visava dinamizar a produção agrícola.

O governo importou máquinas de descaroçar algodão, fazer manteiga, descascar café, lavrar ouro, debulhar milho, moer, espremer e peneirar mandioca, além de um tear, uma máquina de fazer 12 milheiros de tijolos por dia, 1 bomba d'água de movimento contínuo, 2 arados, 1 cultivador, grades para campos e uma charrua da marca Mr. Rodes. Pela lei esses modelos e máquinas foram expostos ao público em um armazém e disponibilizados a fim de que por

\footnotetext{
${ }^{3}$ GONÇALVES, Reinaldo. Globalização e desnacionalização. São Paulo: Paz e Terra, 1999, p.12.

${ }^{4}$ PINTO, Virgílio Noya. Balanço das transformações econômicas no século XIX. In MOTA, Carlos Guilherme (org.). Brasil em Perspectiva. 15ª ed. São Paulo: DIFEL, 1985, p.134.

${ }^{5}$ Ibid.

${ }^{6}$ Ibid.
} 
eles se fizessem as máquinas que a qualquer indivíduo conviesse usar. ${ }^{7}$

O Ceará encetava o caminho do progresso material sob os auspícios da agricultura de exportação. Isso repercutiu na exposição de produtos agropecuários e da terra em eventos agrícolas. O presidente Manoel Duarte de Azevedo considerou o fato da participação do Ceará na Exposição Agrícola de 1861 como um "acontecimento notável, e de grandes resultados para o desenvolvimento da prosperidade da província, que a olhos vistos progride com passos agigantados". ${ }^{8}$ A Comissão de Exposição dos produtos naturais e da terra ficou a cargo de Tomás Pompeu de Sousa Brasil, que apesar disso tinha uma visão pessimista do potencial econômico da região.

$\mathrm{Na}$ administração do presidente José de Alencar o comércio na província apresentou um crescimento contínuo. Os rendimentos das alfândegas de 1833 a 1834 foram 27:866\$040, no de 1834 a 1835 foi de 40:433\$817 e no de 1835 a 1836 foi de 56:984\$839. Isso representou um aumento crescente da arrecadação de impostos. No primeiro semestre do ano financeiro se arrecadou na capital 11:648\$806 e em Aracati 1:675\$523. No segundo semestre se arrecadou na capital 24:303\$806 e em Aracati 7:869\$986. Essas eram duas mais importantes cidades portuárias da província.

Esses resultados foram obtidos como conseqüências das medidas modernizadoras da agricultura tomadas pelo presidente, auxiliado pela criação de um banco de desconto, circulação e depósito na capital. ${ }^{9}$ A existência de uma sólida instituição de crédito como o Banco da Inglaterra fundado em 1694 foi

\footnotetext{
${ }^{7}$ NOBRE, Geraldo da Silva. O processo Histórico de Industrialização do Ceará. Fortaleza, SENAI/DR-CE. Coordenadoria de Divulgação, 1989, p 88-89.

${ }^{8}$ APEC - Relatório do presidente da província Manoel Duarte de Azevedo. de 1862, Manoel Duarte de Azevedo p.6

${ }^{9}$ LAVOR, Raimundo. Duas "falas" do senador Alencar. Revista do Instituto do Ceará. Tomo

LVI, 1947, p.289.
} 
um dos motivos do pioneirismo inglês na Revolução Industrial.

É importante ressaltar o progresso da província havido a partir da administração do presidente José de Alencar. Antes desse período observou o botânico Freire Alemão que a cidade de Fortaleza era insignificante, com poucos estabelecimentos comerciais e de produção, mas que na administração desse presidente tudo prosperou muito, principalmente com a fundação de um banco provincial; pois "antes dele não havia dinheiro, era tudo miséria" ${ }^{10}$, mas com a criação do banco "apareceram edifícios e muito prosperou a cidade. Foi Alencar que deu impulso à cultura da cana de açúcar". ${ }^{11}$

Com isso, a primeira metade do século XIX até a chamada "grande seca" foi um período de prosperidade para o Ceará devido às medidas progressistas tomadas pelo presidente Alencar e pelos seus sucessores no governo da província. Observou Geraldo Nobre que das 6 exposições nacionais realizadas no Brasil de 1861 a 1889 o Ceará deixou de participar de apenas 1.

Entre as províncias que tiveram participação total podemos citar a província e o Município Neutro (Corte) do Rio de Janeiro, São Paulo, Paraná, Santa Catarina, Rio Grande do Sul e Minas Gerais. Quanto às províncias do Norte (do Amazonas à Bahia), "Pernambuco foi a única a fazer parte desse grupo". ${ }^{12} \mathrm{Na}$ exposição de 1866 o Ceará foi representado por José Júlio de Albuquerque Barros que se tornou presidente da província em 1878 e como aliado do senador Pompeu apoiou o início de uma política de incentivo à atividade manufatureira.

Em decorrência do desenvolvimento da agricultura de exportação as

\footnotetext{
${ }^{10}$ NOBRE, Geraldo da Silva. Op. cit., p, 90.

${ }^{11}$ Ibid.

${ }^{12}$ Ibid. O professor Geraldo Nobre discorda de Freire Alemão dizendo que antes do governo do presidente Alencar Bernardo Pereira de Vasconcelos havia dado início a um empreendimento bancário.
} 
oficinas se multiplicaram na capital cearense, tanto pela ampliação do número de licenças concedidas para o seu funcionamento, quanto pelos dividendos dela provenientes, que renderam para a municipalidade 80 mil réis em 1864, e no ano seguinte 210 mil réis. Isso refletia a situação geral da província, cuja arrecadação relativa a esse setor em 1865 se elevara a quase 584 contos de réis, enquanto a média do período de 1845-1849 ficara em 81 contos. Esse crescimento foi superior ao registrado em qualquer outra província do Norte, incluindo-se a Bahia. ${ }^{13}$

Em 1853 o presidente da província Joaquim Vilela de Castro Tavares, falando à Assembléia Legislativa Provincial observou que a agricultura era a atividade que convinha fortalecer principalmente. Ao se investir na agricultura, multiplicavam-se os produtos, que poderiam abastecer o comércio em grande escala. Com isso, "a indústria manufatureira" criar-se-ia como por encanto, e a província do atraso em que está surgir a opulência”. ${ }^{14}$

Observe-se que o presidente estabeleceu como pré-condição para o crescimento da indústria manufatureira o desenvolvimento da agricultura de exportação. Ele partiu de uma perspectiva moderna, segundo a qual a ciência e a arte aceleravam o trabalho útil, refaziam o clima, criavam as condições para o solo, pois “A natureza dá e exige ao mesmo tempo". ${ }^{15}$

Nesses termos o presidente afirmou no seu relatório que "Animar e proteger a indústria não é mais do que estabelecer as condições necessárias para que ela se desenvolva e floresça". ${ }^{16}$ Entre as condições ele assinalou "a

\footnotetext{
${ }^{13}$ Ibid., p.87.

${ }^{14}$ Ibid.

${ }^{15}$ Ibid, p. 85 .

${ }^{16}$ Ibid.
} 
segurança de propriedade". ${ }^{17}$ Com isso, a violência foi percebida como um aspecto impeditivo ao desenvolvimento econômico. As outras condições seriam a educação profissional, as vias de comunicação, a aplicação de máquinas à lavoura, a criação de instituições de crédito, que aproveitadas pelo espírito de associação, produziriam todos os "prodígios da indústria, que tanto maravilham". ${ }^{18}$ As estradas, segundo ele, além de facilitarem o transporte de gêneros, dispendiosamente conduzidos por estreitas e escarpadas veredas, serviriam também como meio de propalar a administração e o governo.

As medidas propostas por Vilela de Castro estavam em sintonia com o que pensava o senador Alencar, a liderança liberal mais importante da província, pois ainda não havia despontado o senador Pompeu. Castro insistiu para que a Assembléia e o governo facilitassem a introdução de máquinas. Isso possibilitaria maior eficácia no aproveitamento das forças da natureza, que poupariam aos trabalhadores pesados trabalhos e dariam perfeição aos produtos, tornando-os mais competitivos.

A influência das máquinas segundo ele já era utilizada principalmente na indústria manufatureira, mas na agricultura elas também eram necessárias. Entretanto, diante da constatação de que muitos agricultores não podiam obtê-las, devido ao seu alto preço, ele sugeriu que o governo as importasse e as distribuísse entre os agricultores.

O Ceará de acordo com o presidente Joaquim Vilela de Castro deveria observar algumas imposições que poderiam, na compreensão dele, afetar a atividade agroexportadora. Entre essas imposições estava a necessidade de reduzir o imposto de exportação, que poderia representar um problema para a

\footnotetext{
${ }^{17}$ Ibid.

${ }^{18}$ Ibid.
} 
arrecadação provincial, mas tornaria a agroexportação cearense mais competitiva no comércio exterior.

Segundo ele, a Câmara e o Senado, reconhecendo que os direitos de exportação eram um ônus muito pesado autorizaram o governo do Império a diminuí-los gradualmente, e este por decreto de 23 de março de 1853 reduziu-os a 5\% por cento. Admoestou à Assembléia Provincial do Ceará para que não aumentasse os direitos de exportação (impostos) relativos aos "gêneros da província acompanhando assim o pensamento do corpo legislativo geral, e do governo imperial reduzindo-os também gradualmente". 19

Toda essa preocupação com a produção econômica tinha por fim fazer progredir a província. Porém, o progresso econômico se relacionava diretamente no século XIX à construção de obras públicas, pois a atividade econômica fosse a agroexportação, o comércio ou atividade manufatureira era o meio para se chegar esse objetivo. No entanto, os recursos eram mal empregados. O presidente da província em 1867, João Alvim, criticou a forma como a assembléia distribuía o dinheiro para as obras públicas, defendendo que esta deixasse ao executivo o papel de decidir como melhor aplicá-lo.

Na sua compreensão a distribuição dos recursos em parcelas para uma multiplicidade de obras retirava a objetividade dos recursos empregados. Ele destacou que desde 1835 vinham crescendo os gastos com obras públicas, porém “percorra-se o Ceará, examine-se suas estradas, e diga-se em vista do que se tem empregado nelas, se possui o que deveria possuir depois de tantos anos de assíduo trabalho e constante despesa". ${ }^{20}$ Para corroborar seu argumento o

\footnotetext{
${ }^{19}$ NOBRE, Geraldo da Silva. O processo Histórico de Industrialização do Ceará. Fortaleza, SENAI/DR-CE. Coordenadoria de Divulgação, 1989, p. 86.

${ }^{20}$ APEC - Relatório Do presidente João Souza Mello e Alvim. Tipografia brasileira: Fortaleza, 1867, p. 23.
} 
presidente divulgou no seu relatório as quantias gastas com obras públicas de 1835 a 1866:

QUANTIAS DESPENDIDASCOM OBRAS PÚBLICAS ENTRE OS ANOS DE 1835 A 1866 PELA PROVÍNCIA DO CEARÁ

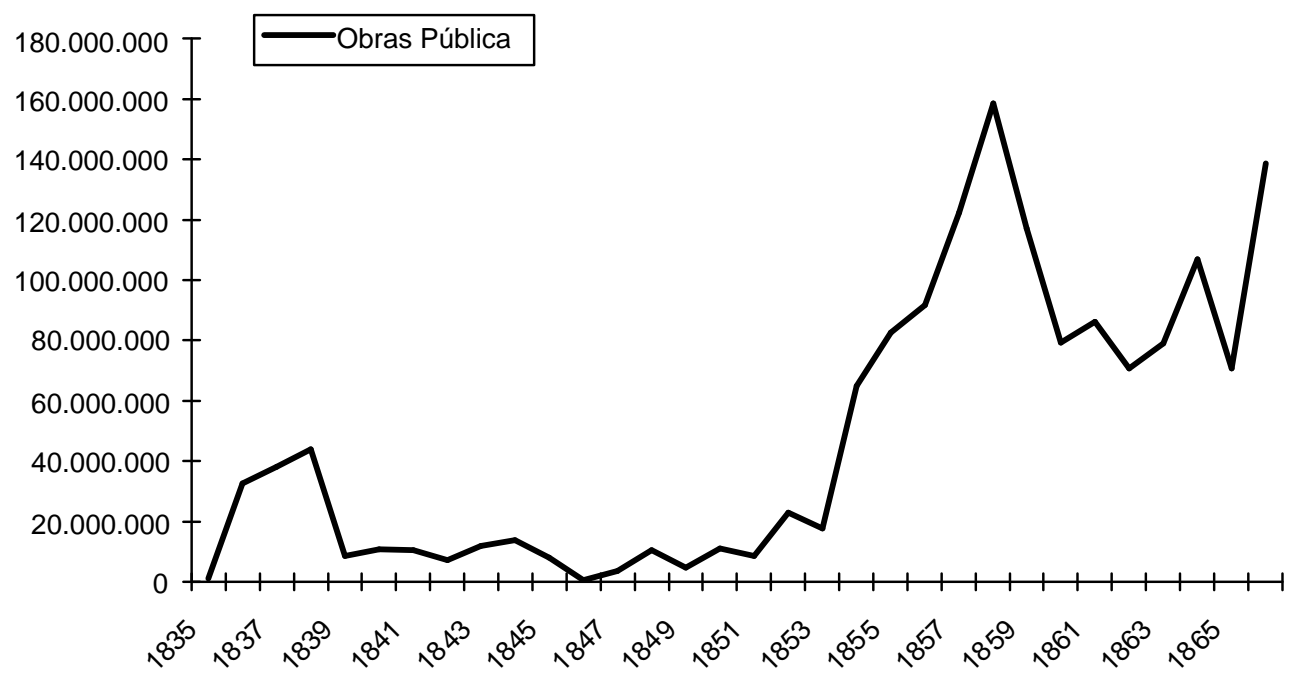

Fonte: Relatório do presidente da província do Ceará João de Souza Mello Alvim. Tipografia brasileira: 6 de maio de 1867, p. 23.

Segundo o presidente da província deveria ser dado à Repartição de Engenharia e Presidência à "atribuição de ocorrer os melhoramentos reclamados pela lavoura e comércio". ${ }^{21}$ Com isso, os investimentos seriam concentrados na melhoria da lavoura e do comércio, assim como as obras realizadas teriam que ter esses ramos da economia como foco. Podemos concluir observando o gráfico acima que durante a seca de 1845-46 houve uma diminuição dos capitais empregados em obras públicas, algo diferente do que ocorreu entre a seca de 1877-79 e a seca de 1900 quando houve um aumento dos capitais empregados em obras públicas.

Contudo, antes dessa seca havia uma crítica a falta de iniciativa particular e a sobrevalorização da ação do estado, pois a idéia de se utilizar a mão de obra disponível durante as secas ainda não era uma realidade. $\mathrm{O}$

\footnotetext{
${ }^{21}$ Ibid.
} 
deputado provincial Manuel Franklin do Amaral em discurso à Assembléia Legislativa no dia 13 de julho de 1855, observou que o governo era visto pela população como a entidade capaz de promover as realizações materiais necessárias à província.

Havia uma noção, segundo a qual, os empreendimentos feitos pelo governo eram sempre mais rápidos e melhores "porque, entre nós, ainda o povo está persuadido que o governo, e só o governo é tudo".22 Para o deputado enquanto esta idéia não desaferrasse “do vulgo, não haverá remédio senão depositarmos nas mãos do governo os meios de poder beneficiar nossa terra". ${ }^{23}$ A parir da constatação da falta de iniciativa, ele ponderou que restava ao Ceará esperar que o imperador mandasse presidentes que se unissem à Assembléia e “que tivessem respeito às leis e bons desejos, porque dessa forma a província há de prosperar". 24

A realidade era que apesar disso a província vinha prosperando tanto pela ação do estado quanto pela particular. Em 1861 o ministro do Império se dirigiu ao presidente da província, afirmando constar-lhe que no Ceará existia uma fábrica de ferro. Pediu que o governo lhe informasse com os esclarecimentos que obtivesse sobre essa fábrica, "o estado em que ela se achava, a quantidade de sua produção e o valor desta nos respectivos mercados". ${ }^{25}$

O presidente Joaquim Vilela de Castro Tavares em 1853 já havia observado que a indústria na província não estava em tão grande atraso como geralmente se supunha, mas carecia ainda de muito estímulo, para chegar ao

\footnotetext{
${ }^{22}$ NOBRE, Geraldo da Silva. Op. cit., p. 59.

${ }^{23}$ Ibid.

${ }^{24}$ Ibid..

${ }^{25}$ Ibid.,p. 63.
} 
ponto que prometiam os seus recursos naturais. Segundo ele, a província tinha "um solo fértil, onde a produção é apenas contrariada às vezes pela seca" ${ }^{26}$ Era habitada por uma população prolífica, que não carecia de inteligência e atividade, quando era bem dirigida, e arrematou "o Ceará tem todas as proporções para vir a ser uma das estrelas mais belas do Império". ${ }^{27}$

A respeito dessa fábrica de ferro, que teria sido o embrião da siderurgia cearense, não se sabe se ela prosperou, mas apenas que existiu. Vê-se com isso que o Ceará estava no caminho correto, como indicaram os estudos do GTDN em 1858. De acordo com o grupo as dimensões do mercado do Nordeste justificavam a instalação de um núcleo de indústria siderúrgica na região, "núcleo esse que deverá permitir a expansão de indústrias de transformação do ferro e aço e mecânicas, que existem atualmente de forma embrionária”. ${ }^{28}$

A afirmação do presidente Joaquim Vilela de Castro de que o Ceará poderia vir a ser "uma das estrelas mais belas do Império" ${ }^{29}$ não era força de expressão. Isso não quer dizer que a seca não existisse enquanto problema latente, haja vista a experiência com a estiagem de $1845-46 .{ }^{30}$ Porém, o modo como ela foi encarada até a seca de 1877 confirma essa possibilidade. O antecessor do presidente Castro, Joaquim Marcos de Almeida Rego recebeu um comunicado do governo imperial no qual este se dizia "achar habilitado com os meios precisos para investigar as causas das secas nas províncias, que são delas flageladas[...]", ${ }^{31}$ porém, observa Almeida Rego:

\footnotetext{
${ }^{26}$ Ibid.

${ }^{27}$ NOBRE, Geraldo da Silva. O processo Histórico de Industrialização do Ceará. Fortaleza, SENAI/DR-CE. Coordenadoria de Divulgação, 1989, p. 84.

${ }^{28}$ GTDN - Uma Política de Desenvolvimento para o Norte. Revista Econômica do Nordeste, v. 28, n.4, p387-432, out./dez., 1997, p.427.

${ }^{29}$ Apud NOBRE, p.

${ }^{30}$ BEZERRA, José Tanísio. Quando a ambição vira projeto: Fortaleza, entre o progresso e o caos (1846/1879). Mestrado em História Social, PUC/SP, 200.

${ }^{31}$ APEC - Relatório do presidente da província do Ceará Joaquim Marcos de Almeida Rego.
} 
[...] nada até o presente se tem feito nesta; porquanto sendo, como é, de presumir, que as causas das secas provenham da sua posição topográfica, e das circunstâncias peculiares do seu solo, nada se pode encetar a respeito, sem que hajam aqui homens habilitados com conhecimentos próprios e adaptados, que possam propor com segurança os meios de impedir os progressos do mal e de moderar seus terríveis efeitos. Em conseqüência disto, e por não haver na província uma só pessoa, que possua aqueles conhecimentos, solicitei do governo imperial a nomeação de uma comissão de engenheiros, e é de crer que esta solicitação seja satisfeita, visto como é da maior urgência”. ${ }^{32}$

O presidente Almeida Rego durante a sua gestão enfrentou uma ameaça de se seca que como veremos não se confirmou. Contudo, é importante perceber nesse episódio três coisas: o governo provincial solicitou ao Império ajuda técnica, segundo; ele próprio realizou a compra da farinha para o socorro público aos desvalidos e, terceiro: havia a compreensão de que essa ajuda técnica viria no sentido de propor meios de impedir a progressão da calamidade e de moderar os seus efeitos. Ainda não se falava em uma política de combate às secas, pois até 1877 estas não aparecem como um óbice à agricultura, mas apenas uma breve contrariedade.

Outro aspecto importante a se observar foi que o presidente Almeida Rego não deu a farinha aos retirantes, mas a vendeu por um preço a baixo do custo. O motivo de ele ter comprado foi "sustentar no mercado um preço baixo, como a consideração dos poucos meios de que dispõe a pobreza" e porque essa farinha ao chegar ao Ceará, "achava-se modificado o preço por causa do aumento das chuvas". 33 O aumento inflacionário era um aspecto comum às secas. Isso ocorria tanto pelo colapso da lavoura de subsistência quanto pela

\footnotetext{
Tipografia cearense, 1853, p.22.

${ }^{32}$ Ibid.

${ }^{33}$ Ibid.
} 
ação de especuladores que mantinham os gêneros estocados esperando o auge da seca para vendê-los ao governo por um preço elevado.

Em 1859, seis anos depois, o governo imperial enviou ao Ceará a Comissão Científica de Exploração. Essa comissão era formada pelos principais homens de ciência da época como o geólogo Guilherme Schüch (barão de Capanema), o astrônomo Giácomo Raja Gabaglia, o botânico Manoel Freire Alemão e o zoólogo Manoel Ferreira Lagos. A partir desse momento iremos falar dessa comissão inserindo-a no debate sobre a seca. A razão disso é que a historiografia costuma relegá-la a algo do passado, marginalizando-a da discussão política e técnica sobre as estiagens no Norte do Brasil. Isso ocorreu porque a Comissão tinha uma visão da seca e do território oposta a que se tornou oficial em 1877 - a noção da seca como óbice ao progresso e do espaço como escasso de recursos naturais.

Na senda do que havia sido proposto pelo presidente Almeida Rego, ou seja, de se encontrar meios para amainar os efeitos das secas, estavam as observações feitas pelo barão de Capanema. Ele analisou a geologia e a flora cearense, constatando que durante as secas as plantas não estavam mortas, apenas dormiam sem folhas, sem um vestígio de verdura e toda força vegetativa ficava na mais perfeita quietação. A esse estado desolador em aparência se devia atribuir à prodigiosa fertilidade daqueles terrenos, pois ao penetrarem os agentes atmosféricos por aquela terra seca e porosa, contribuía para a decomposição dos seus elementos, que serviam depois de adubo. "Em outros lugares com trabalho se revolve a terra, arando-a profundamente para expô-la ao ar". ${ }^{34}$

Portanto, com a visita da Comissão Científica de Exploração foram

\footnotetext{
${ }^{34}$ BRAGA, Renato. História da Comissão Cientifica de Exploração. Fortaleza: Imprensa Universitária do Ceará, 1962, p. 294.
} 
colocadas as condições técnicas para o desenvolvimento da pecuária e da agricultura cearense, o que garantiria uma oferta considerável de alimentos. Essa era uma questão importante, pois segundo O GTDN em 1958 o principal obstáculo à industrialização do Nordeste era a oferta inelástica ${ }^{35}$ de alimentos, ou seja, "uma agricultura incapaz de suprir, na quantidade requerida e a preços razoavelmente baixos, os gêneros de que necessitam as populações urbanas para dedicar-se às tarefas industriais". 36

Os cientistas da Comissão Científica de Exploração que vieram ao Ceará em 1859 entraram em contato com Thomas Pompeu, renomado geógrafo que veio a se tornar o senador cearense mais influente do Império. Na casa do senador Pompeu, de acordo com Renato Braga "reuniam-se, para longas palestras e debates em volta dos problemas fundamentais da Província, as figuras mais graduadas da Comissão". 37

Entre os problemas principais estava certamente a seca e a questão do atraso material das províncias do Norte. Porém, nos debates ocorridos na casa do senador ficou clara a diferença de posições entre os membros da Comissão Científica e o grupo do senador Pompeu. Para os membros da Comissão as secas não impediam o desenvolvimento econômico da província, mas para o grupo de Pompeu a seca era um obstáculo ao progresso da região.

Esse foi um aspecto contestado por Capanema que para tanto elaborou uma proposta de modernização da lavoura. Ele percebia que no Brasil

\footnotetext{
${ }^{35}$ Sobre isso vide SINGER, Paul. Aprender Economia. $24^{\text {a }}$ ed., São Paulo: Contexto, 2006, p.1314. Em economia existem mercadorias cujos preços são elástico (produtos industrializados) e mercadorias cujos preços são inelásticos (produtos agrícolas). A oferta inelástica dos produtos agrícolas tem como consequiência a elevação dos preços. Para o GTDN a falta de alimentos no mercado levava a população a ter que plantá-los ao invés de se dedicar às tarefas industriaisurbanas.

${ }^{36}$ GTDN - Uma Política de Desenvolvimento para o Norte. Revista Econômica do Nordeste, v. 28, n.4, p387-432, out./dez.,1997, p, 423.

${ }^{37}$ BRAGA, Renato. História da Comissão de Exploração. Imprensa Universitária: Fortaleza, 1962, p.
} 
não havia um método agrícola que pudesse ser propalado por diversas localidades. Propôs a criação de um Instituto Agrícola para praticar a lavoura racional que consistia em tentativas, ensaios e experiências, das quais muitas poderiam falhar. Por esse motivo ele defendia a idéia de que não se deveria esperar que capitais particulares que sempre procuravam tornarem-se produtivos se aplicassem a experiências. O emprego dos recursos deveria "correr por conta e debaixo da fiscalização imediata do governo". ${ }^{38}$ Essa era uma proposta importante, pois como afirmou Gilberto Freyre "Em toda parte, o processo de agricultura destruidora da natureza dominou com maior ou menor intensidade no Brasil patriarcal”. 39

Numa das várias cartas enviadas ao rei em 1860, Capanema disselhe que havia achado "os ricos depósitos de mineral de ferro da melhor qualidade, não no mesmo lugar onde os achara Feijó em 1814". ${ }^{40}$ O naturalista e sargento-mor João da Silva Feijó foi encarregado por sua Alteza Real, a época do Ceará capitania de produzir investigações filosóficas, ou seja, científicas, sobre as possibilidades de aproveitamento do potencial econômico da região. A população do Ceará nessa época, quando a capitania já tinha 200 anos, remontava a pouco mais de 150 mil habitantes. Os depósitos de ferro eram uma descoberta importante para o desenvolvimento da metalurgia e crucial para o progresso da província.

Uma vez adquirido o método mais racional, devia-se propalá-lo simultaneamente no maior número possível de localidades, o que seria muito fecundo ao governo. Após essa fase se passaria a aplicar métodos experimentados, cujos resultados já eram comprovados, cabendo então os

\footnotetext{
${ }^{38}$ ANRJ - Documentos do Barão de Capanema, maço 131 - doc 6452, do6, p.01.

${ }^{39}$ FREYRE, Gilberto. Sobrados e Mucambos. $7^{\mathrm{a}}$ ed. Rio de Janeiro: José Olympio, 1985, p. 21.

${ }^{40}$ BNRJ - Documentos do Barão de Capanema. Maço 129, Doc 6344- [D01-P01].
} 
investimentos de capitais particulares individualmente ou associados, que poderiam contar com os bons serviços do Instituto Agrícola. Quando os lavradores vissem no mercado alguns produtos de boa qualidade do estabelecimento, iriam eles mesmos, ou mandariam seus filhos matricularem-se na nova escola, onde eles deveriam esquecer que "tinham escravos em casa". ${ }^{41}$

Para conservar grãos como feijão, milho e arroz durante um longo período de tempo que para Capanema "Em parte era causa da fome, pois quando passava um ano sem chover ficava difícil conservar os alimentos" ${ }^{42}$, percebeu que se poderia usar o sulfureto de carbono. Método mais conveniente que o uso do mercúrio por alguns produtores que quando misturado com o sal de cozinha se tornava um sublimado corrosivo, portanto maléfico à saúde da população sertaneja.

Mas, nada admirou tanto o geólogo do que os criadores de gado de Quixeramobim, onde a pecuária era a principal atividade econômica. Essa atividade foi ao longo das secas a mais castigada, devido à falta de pasto. Ele observou que o rebanho engordava durante o inverno e as vacas que pariam no fim da seca sustentavam com leite os bezerros e os homens que, mais pareciam seres da mesma espécie, pois passavam a viver de queijo, leite fresco e coalhada.

Entretanto, logo que cessavam as chuvas desaparecia a abundância, o gado se alimentava de capim seco, que ia cada vez mais rareando, esturricado pelo sol até chegar a um estado de se reduzir a pó com extrema facilidade. Toda a gordura acumulada pelo gado nos quatro meses de inverno era perdida aos poucos nos meses de estio. Se em janeiro não chovesse cessava esse recurso e o

\footnotetext{
${ }^{41}$ ANRJ - Barão de Capanema ao Imperador Pedro

${ }^{42}$ ANRJ - Resumo apresentado pelo Barão de Capanema ao Imperador Pedro II. 1860.
} 
gado morria todo de fome no meio do mais bem sortido pasto. Os criadores deram ao Capanema uma explicação no mínimo engenhosa: segundo eles os bichos sofriam de uma afecção moral, pois quando o pasto deixava de ser regado no tempo certo se recusavam a comê-lo.

Se depois do capim secar caísse uma chuva, dependendo da sua duração, o pasto ou apodrecia ou ficava esbranquiçado como se fosse banhado de cloro. Observou José do Patrocínio, a respeito da mentalidade míticoreligiosa dos cearenses, no seu romance Os Retirantes, que o povo se comportava de modo supersticioso ao notarem algo como um "círculo alourado em torno da lua, a queda de um meteoro, as cores do crepúsculo", ${ }^{43}$ de modo que tudo era prognosticado como prenúncio da esperada desgraça.

Contudo, os estudos geológicos desenvolvidos por Capanema e apresentados ao rei estavam ligados a uma compreensão dos problemas do povo cearense. Guilherme Schüch não se cansava de reafirmar a D. Pedro II a importância dos seus estudos sobre agricultura, pastos e criação de gado, mas, sobretudo, sua avaliação a cerca do estado da "civilização do povo". No entanto, D. Pedro II, como asseverou José Maria Belo "Não foi um estadista; faltava-lhe visão de conjunto, o gosto da política, a coragem de ousar". ${ }^{44}$

Sobre a escassez de pasto o naturalista Adolf Loefgren leu e comentou em um dos relatórios do chefe da Comissão de Açudes de Quixadá (cidade localizada no sertão central), o engenheiro Piquet Carneiro, no qual este atribuía à mortalidade do gado na época da seca, não tanto a falta de água, mas principalmente a falta de alimento, o que estava de acordo com as observações

\footnotetext{
${ }^{43}$ PATROCÍNIO, José do. Os Retirantes. (primeira edição de 1879). Vol. I e II. São Pulo: Editora Três, 1973, p.3.

${ }^{44}$ BELLO, José Maria. História da República (1889-1930): sintese de quarenta anos de vida brasileira. $2^{\mathrm{a}}$ rev. e aum., Rio de Janeiro: Simões, 1952, p.20.
} 
do naturalista. De acordo com Loefgren essa falta de alimento provinha, principalmente, do fato de se deixar "perder a imensa provisão de forragens que, todos os anos, mesmo nos considerados precários, abundam nas caatingas". ${ }^{45}$ Isso apenas confirma a proposta do barão de Capanema de se estocar pasto nos anos regulares para alimentar o gado nos anos de escassez forragem e grãos.

Capanema sugeriu ao rei Pedro II que seria útil mandar, mesmo a peso de ouro, ensinar a preparar a conservação do feno. Ele acreditava mesmo não ser absurdo, dar-se um prêmio de 20 ou 30 contos ao fazendeiro do Ceará, Rio Grande do Norte ou Paraíba que mantivesse 100 vacas nutridas a feno da terra em curral durante três anos consecutivos e conservados gordos. Ponderou ainda não ser nenhum exagero conceder-se mesmo um título de nobreza "e tenha V.M. a certeza que até um marquesado alcançado por esse modo daria muito mais brilho e honra a sua corte do que esses miseráveis traidores da pátria que pela sua ignorância nos tornam ao muito dignos rivais da costa d’África." ${ }^{46}$

Com isso, Capanema considerava que o centro do problema estava em dar maior estabilidade à oferta de alimentos, algo diferente do que pensava o GTDN que partiu do suposto que a raiz do problema estava "em dar maior estabilidade à renda real do trabalhador, e não a oferta de alimentos". ${ }^{47}$ Assim sendo, o grupo considerava que para criar uma economia mais resistente aos efeitos das secas, o primeiro passo seria "reduzir o âmbito da agricultura de subsistência, ou seja, em aumentar a faixa monetária". 48 No entanto, a fragilidade da agricultura não apenas de subsistência se devia ao seu atraso

\footnotetext{
${ }^{45}$ LOEFGREN, Alberto. Ceará: Notas botânicas. Revista do Instituto do Ceará. Tomo XXV, 1911, p.164-165.

${ }^{46}$ ANRJ - Documentos do Barão de Capanema. ....

${ }^{47}$ GTDN - Uma Política de Desenvolvimento para o Norte. Revista Econômica do Nordeste, v. 28, n.4, p387-432, out./dez.,1997, p 421.

${ }^{48}$ Ibid.
} 
técnico. Mas, a proposta do GTDN se baseava em dirimir os efeitos da secas acabando com a pequena lavoura.

No sentido inverso as propostas do Barão de Capanema eram incentivos poderosos que despertariam o censo de empreendedorismo e racionalidades na agricultura, na pecuária e na mineralogia. Elas era fundadas em conhecimento técnico e por isso possibilitariam ao Ceará e as províncias vizinhas alcançarem o progresso material que as diferenciava em relação às províncias do Sul. Capanema observou ainda que o ferro consumido no interior do Ceará, do Piauí e de Pernambuco era todo inglês e muitas vezes de péssima qualidade, transportado a duzentas e mais léguas, em costas de animais.

Em conseqüência disso ele propôs ao governo imperial que mandasse ensinar ao povo cearense o meio de aproveitar a mineira de ferro para obter material, ao menos o necessário para as suas ferramentas de lavoura; que o povo industrioso não tardaria a construir as pequenas forjas catalãs e fabricar ferro e aço para o consumo de cada distrito. "Objeto este de grande utilidade para aqueles lugares". 49

Nesse período não se alegou que houvesse escassez de recursos naturais ou que a seca fosse um entrave ao progresso da região. O naturalista João da Silva Feijó, a época do Ceará capitania, alegou como motivo desta não ser próspera devido aos grupos indígenas, que ele considerava incapazes para "se felicitarem ou fazerem à felicidade dos outros; ou por causa da sua constituição física, falta de educação ou algum capricho particular". ${ }^{50}$

Segundo ele, outra parte da população era formada pela mistura de índios e negros, conhecidos pela vil denominação de cabras. E havia os nascidos

\footnotetext{
49 BRAGA, Renato. História da Comissão Científica de Exploração. Fortaleza: Imprensa Universitária do Ceará, 1962, p.294.

${ }^{50}$ Ibid.
} 
dos intercursos sexuais entre índios com os brancos, chamados de mamelucos. A última classe, a mais diminuta, era certamente a dos brancos provenientes de Portugal. Feijó, cujo estudo visava conhecer o potencial material da capitania reprovava duramente os costumes dessa população de índios, negros, mamelucos e brancos por considerá-los assaz indolentes.

Assim, na opinião dos presidentes da província na primeira metade do século XIX, do naturalista Feijó, e do deputado Manuel Franklin do Amaral o progresso do Ceará dependeria da iniciativa popular, de boas administrações e da garantia da propriedade privada. Após as revoltas regenciais e com o regresso conservador o Ceará encetou uma política de combate à violência e de fomento ao crescimento econômico. O barão de Capanema percebeu que nos domingos as pessoas iam até a igreja matriz para ouvir missa, porém não era carolice, além do sentimento religioso, havia o interesse de manter boas relações e sanar divergências entre as pessoas e discutir os interesses da comunhão.

De fato, de 1852 a 1862 o Ceará manteve um intenso comércio interno e externo. Os principais produtos da pauta de exportação cearense eram o algodão, o café, o açúcar e os couros salgados secos, além de outros gêneros. De 1862 a 1871 o Ceará exportou esses produtos para dentro e para fora do país:

TABELA 4 EXPORTAÇÃO EFETUADA NO PRIMEIRO TRIMESTRE DE 1865 PELOS

\begin{tabular}{l|l}
\multicolumn{2}{c}{ PORTOS DO CEARÁ } \\
\hline \multicolumn{1}{c}{ Produto } & \multicolumn{1}{c}{ Valor } \\
\hline Algodão & $571: 016 \$ 240$ \\
Café & $100: 164 \$ 500$ \\
Borracha & $4: 015 \$ 320$ \\
Sola & $186 \$ 000$ \\
Sebo & $1: 321 \$ 260$ \\
Cera de Carnaúba & $4: 795 \$ 660$ \\
Açúcar & $36: 790 \$ 440$ \\
Polvilho & $12 \$ 980$ \\
Velas de carnaúba & $434 \$ 000$ \\
Madeiras & $313 \$ 600$ \\
Couros & $60: 185 \$ 00$ \\
\hline Peles & $673 \$ 000$ \\
\hline
\end{tabular}

Fonte: Relatório de presidente de província de 1865 (anexo n.3) 
Em 1865 transcorria a guerra de Secessão interrompendo o fornecimento de algodão dos estados Unidos para a Grã-Bretanha. A cotonicultura cearense tirou proveito dessa situação com o aumento da exportação de algodão. No entanto, o algodão cearense foi um produto importante da pauta antes e depois desse episódio. Assim, como a pecuária cuja exportação apresentou constante crescimento. O chamado binômio gadoalgodão foi a base para o crescimento da economia cearense até a seca de 187779. O Ceará ao se tornar independe da capitania de Pernambuco em 1799 com a abertura dos portos em 1810 passou a manter intenso comércio interno e externo.

\section{GRAFICO 20}

EXPORTAÇÃO DE ALGODÃO E COURO POR KG PELOS PORTOS DO CEARÁ(1062-1870)

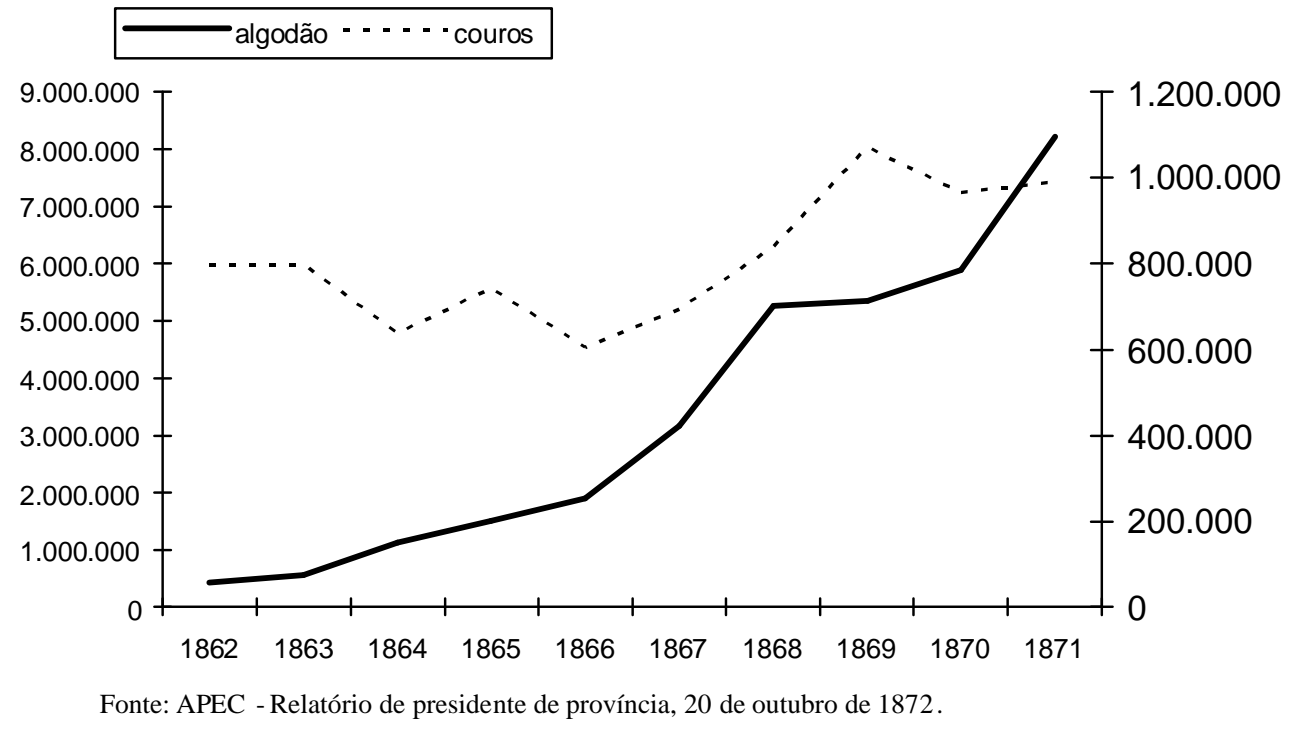

Segundo Márcio Souza de 1847 a 1860 a borracha em peles (discos ou bolas de borracha fina) preparada nos seringais atingiu o primeiro lugar na pauta de exportações da Amazônia. ${ }^{51}$ No Ceará esse setor acompanhou o crescimento dessa região, apresentando considerável crescimento, sobretudo a partir de 1868.

\footnotetext{
${ }^{51}$ SOUZA, Márcio. A expansão amazonense. São Paulo: Alfa Ômega, 1978, p.94.
} 
GRÁFICO 21

EXPORTAÇÃO DE BORRACHA PELO PORTO DE FORTALEZA (1862-71)

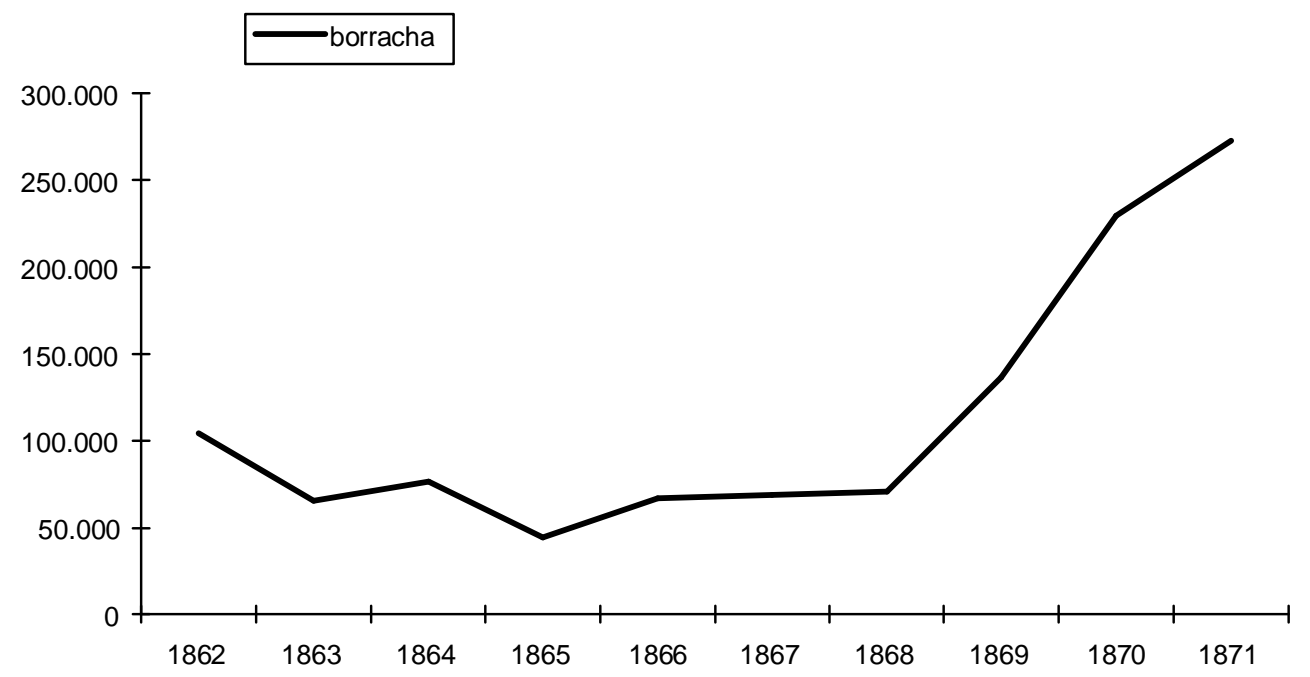

Fonte: APEC - Relatório do presidente de província: 1873, p.41.

Se o algodão, o couro e a borracha apresentaram elevado índice de exportações ao longo de uma década, o mesmo não se poderia dizer a respeito do café e do açúcar como mostra o gráfico abaixo:

GRÁFICO 22

QUANTIDADE DE KG DE CAFÉ E AÇÚCAR EXPORTADO (1862-1871)

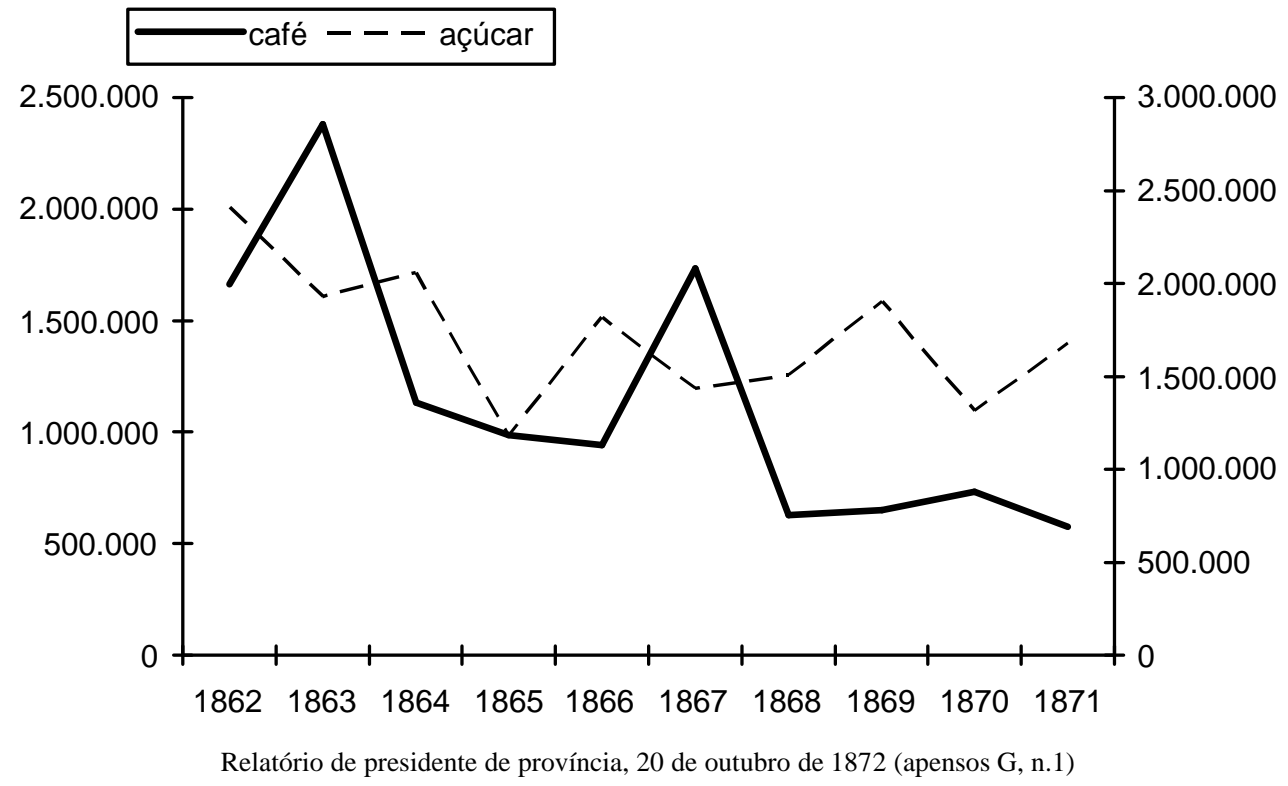


O Ceará baseou seu crescimento econômico de 1836 a 1876 na agroexportação de produtos como o algodão, couros, borracha e açúcar, mas também no café, um produto que se desenvolvia fortemente no Sul do país. A tendência de queda na produção de café ocorreu porque este não se desenvolveu tão bem como no Centro Sul que lhe impingiu forte concorrência. Esse setor que já vinha em declínio entrou em colapso na seca de 1877 .

O problema era que a estrutura produtiva extrativa e a agropecuária como o setor de abastecimento interno, necessário para estabilizar a atividade produtiva agroexportadora e manufatureira dependia da regularidade climática. Os fazendeiros e a população não acumulavam água, nem pasto, nem gêneros alimentícios e contavam com o inverno regular, porém se esse faltasse, como ocorreu em 1877 toda a economia estava perdida.

Após a seca de 1877-79 a agroexportação cearense entrou num período de declínio com a diminuição das exportações de café, açúcar, couro, algodão e borracha porque o governo provincial e estadual decidiu priorizar a atividade manufatureira.

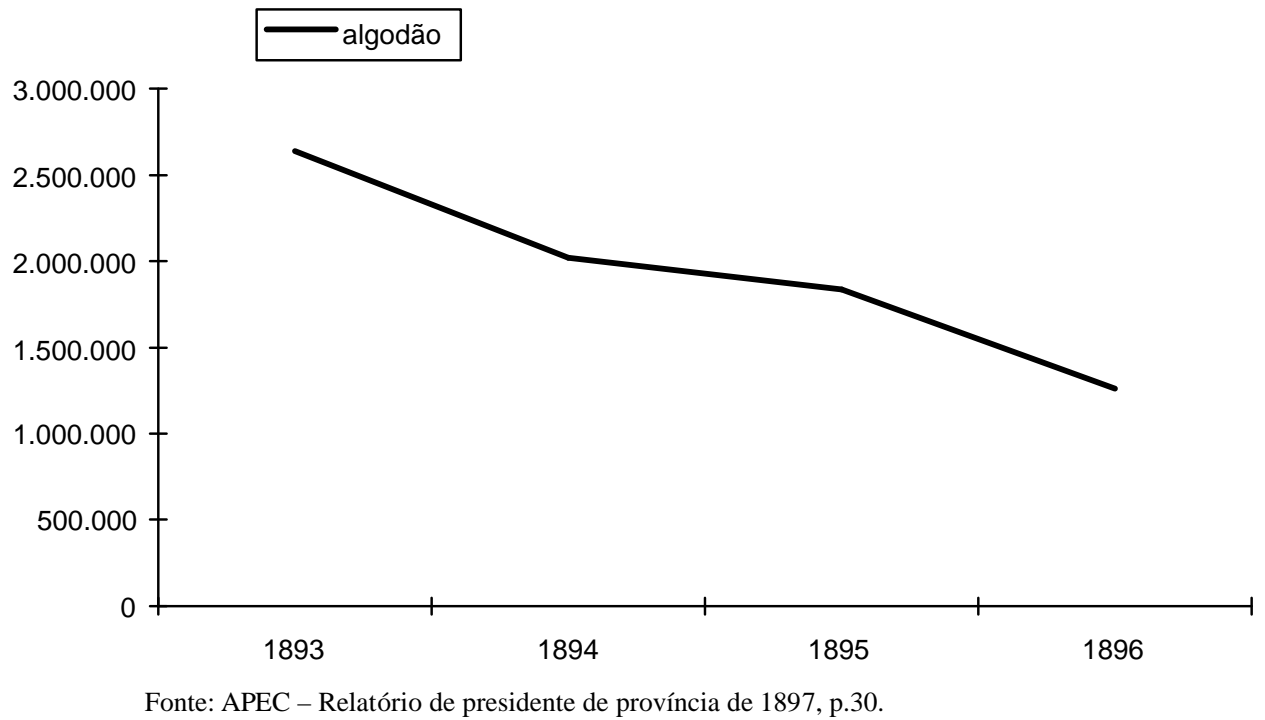


O declínio da produção algodoeira foi crescente. No mesmo período em que a atividade manufatureira se expandia. Essa diminuição da produção algodoeira representava também o declínio ou o estacionamento da indústria têxtil da província pelo fato delas fazerem parte da mesma cadeia produtiva.

GRÁFICO 24

EXPORTAÇÃO DE COURO (KG) PELO PORTO DE FORTALEZA (1893-1896)
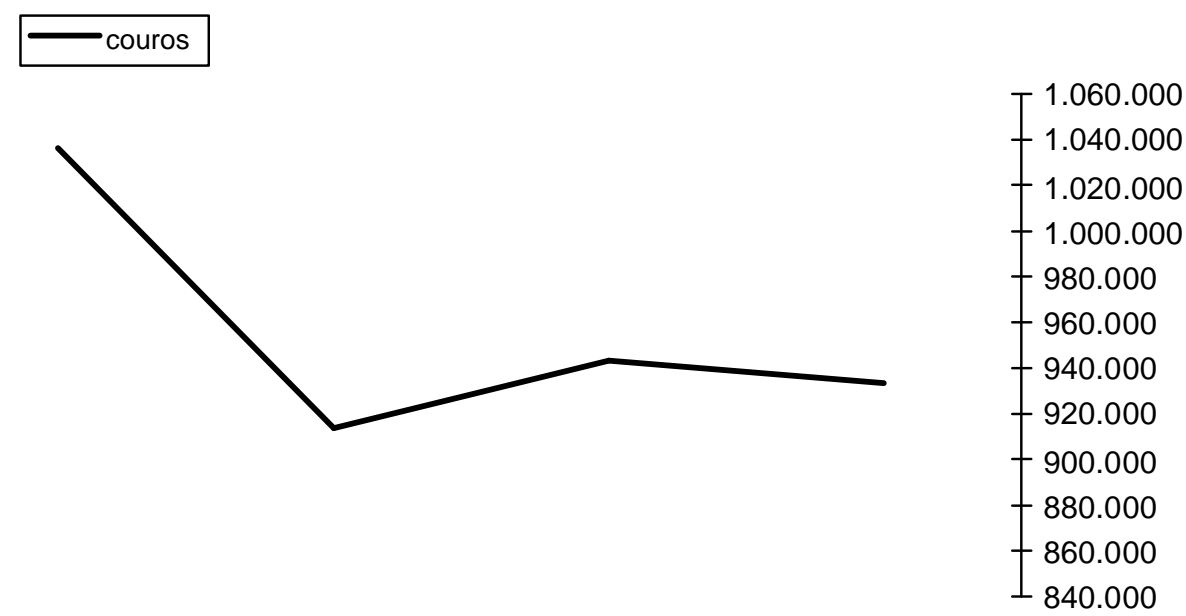

Fonte: APEC - Relatório de presidente de província de 1897, p.30.

Se de um lado os principais produtos da agropecuária do Ceará: o algodão, o couro e a borracha entraram em queda, por outro lado a atividade manufatureira sofreu uma ampliação por meio de uma política de concessões e incentivos por parte do governo da província.

GRÁFICO 24

SETOR FABRIL, MANUFATUREIRO E COMERCIAL CEARENSE(1883-1891).

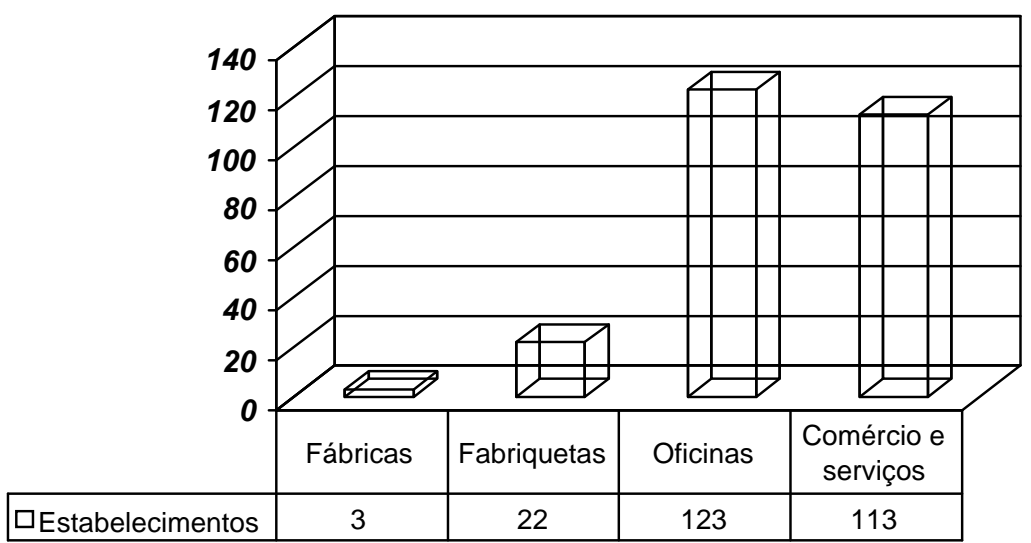

Fonte: MENEZES, Antonio Bezerra de Menezes. Descrição da Cidade de Fortaleza. Fortaleza: Edições UFC/Prefeitura de Fortaleza, 1992, p. 181. 
Além dessa política de incentivos o presidente José Julio de Albuquerque Barros defendeu a necessidade de se modernizar a agricultura e a pecuária. "O melhoramento definitivo das nossas principais industrias depende essencialmente de um instituto, em que teórica e praticamente se habilitem os agricultores e criadores pelo conhecimento das ciências físicas conexas àquelas industrias". ${ }^{52}$ Nem essas idéias não foram implementadas nem as mudanças na política de incentivos, que se dava por meio de concessões à particulares do privilégio para a instalação de oficinas, fabriquetas e fábricas para explorar alguma atividade econômica por até 10 anos.

Porém, durante a dita grande seca (1877-79) o presidente da província José Júlio de Albuquerque Barros criticou esse sistema de incentivos por considerá-lo inconveniente, referindo a indústria têxtil, por esta não se tratar, nem de invenção, nem de melhoramento de descoberta, nem de um serviço que por sua natureza excluísse a concorrência dentro de uma certa zona. Por isso, ele defendeu que "uma subvenção ou garantia de juros por tempo limitado, seria mais justificável”. ${ }^{53}$ No entanto, continuou-se com a mesma política em razão do Tesouro Provincial não ter os capitais suficientes para subvencionar essa atividade.

Concede-se a Antonio Joaquim Guedes de Miranda, ou à empresa que organiza, sem isenção de impostos ou contribuições devidas aos cofres públicos, privilégio por dez anos, para montar e explorar uma fábrica de fósforos nesta capital, ficando a mesma sujeita as leis policiais do estado.[grifos nossos] ${ }^{54}$

\footnotetext{
${ }^{52}$ APEC - Fala com que o presidente José Júlio de Albuquerque Barros, presidente da província do Ceará, abriu a $1^{\mathrm{a}}$ sessão da $24^{\mathrm{a}}$ legislatura, da Assembléia Provincial, no dia 1 de novembro de 1878 , p.22.

${ }^{53}$ Ibid.

${ }^{54}$ APEC - Coleção de Leis do Estado Ceará. Caixa n.3, Livro 125-c, lei n. 660 de 22 de agosto de 1901 .
} 
Essa condição imposta pela concessão, segundo a qual o estabelecimento ficaria sujeito às leis policiais do estado se devia ao fato de após a seca de 1877-79 ter-se formado em Fortaleza um grande número de órfãos desvalidos que eram mandados ao trabalho em fábricas e oficinas espalhadas pela cidade a título de contratos de soldada. A historiadora Maria Izilda S. Matos observou que em São Paulo havia o emprego do trabalho de menores como recurso utilizado pelas fábricas que pagavam baixos salários, exerciam fácil controle sobre esse trabalhador e não exigência de grande conhecimentos técnicos, afora situação de miséria que levava o ingresso precoce das crianças nas fábricas. Ademais o trabalho infantil era imprescindível para o desenvolvimento físico e moral das crianças. ${ }^{55}$

$$
\text { QUADRO } 1
$$

CONCESSÕES PARA INSTALÇÕES FABRIS NO CEARÁ

\begin{tabular}{lll}
\hline Beneficiário & Concessão & Duração \\
Fra $^{c o}$ L. e Carlos Montenegro & Artefatos de flandres & 10 anos \\
Matos Lima e Cia & Fábrica de papel & 10 anos \\
Antônio Guedes de Miranda & Fábrica de fósforos & 10 anos \\
Américo de Matos Lima & Um tear manual & 5 anos \\
João Guilherme da Silva & $\begin{array}{l}\text { Refinação de sal e Preparo de } \\
\text { peixes }\end{array}$ & 10 anos \\
Joaquim Lima de Medeiros & Preparo de mosaicos & 10 anos \\
Vlademiro P. Albuquerque & Fabrica de cerveja & 10 anos \\
\hline
\end{tabular}

Fonte: APEC - Coleção de Leis do Estado do Ceará (1894-1904)

Esses estabelecimentos enfrentaram um problema importante que foi a falta de mercado interno consumidos devido ao empobrecimento do agricultor sertanejo. Com a perda do poder de compra do trabalhador sertanejo que trabalhava sob o regime de meação nas roças e fazendas de gado os produtos manufaturados não encontravam mercado. A política de concessão ao incentivo

\footnotetext{
${ }^{55}$ Cf. MATTOS, Maria Izilda S. Trama e Poder: trajetória e poder em torno da industria de sacaria para o café (São Paulo, 1888-1934). 2ª ed. Rio de Janeiro: Sette Letras, 1996, p.75.
} 
de manufaturas não conseguiu rever o eixo econômico da província que continuo tendo como principal setor a agricultura e a pecuária.

QUADRO 2

DADOS ECONOMICOS GERAIS DE ALGUNS MUNICÍPIOS DO CEARÁ RELATIVOS AO ANO DE 1896

\begin{tabular}{|l|r|}
\hline Descrição & Números \\
\hline Valor do dízimo dos gados grossos & $\mathbf{6 9 . 9 0 7 \$ 4 0 8}$ \\
\hline Valor do dízimo dos gados miúças & $\mathbf{8 5 : 5 5 5 \$ 3 1 3}$ \\
\hline Rendimentos da Coletoria & $858: 811: 578$ \\
\hline Rendimentos da Câmara Municipal & $361: 947 \$ 483$ \\
\hline Número de agricultores & $\mathbf{1 0 3 : ~ [ . . . . ] ~}$ \\
\hline Número de roçados & $\mathbf{1 4 3 : 0 5 8}$ \\
\hline Número de sítios de cana & $9: 618$ \\
\hline Número de fazenda de café & $4: 139$ \\
\hline Número de engenhos de ferro & 777 \\
\hline Número de engenhos de madeira & 1.494 \\
\hline Número de motores a vapor & 103 \\
\hline Numero de aviamento de farinha & $143: 058$ \\
\hline Número de bolandeiras & 878 \\
\hline Número de Alambiques & 665 \\
\hline Número de açudes & $2: 411$ \\
\hline Número de casa no povoado & 22.769 \\
\hline Casas de campo & 123.06 \\
\hline Casas construídas durante o ano & 1.170 \\
\hline Número de casas demolidas & 294 \\
\hline Número de casas restauradas & 827 \\
\hline
\end{tabular}

Fonte: Secretaria da Junta Comercial de Fortaleza, 25 de maio de 1896.

Esses dados, apesar de incompletos dão uma noção da conjuntura produtiva interna do Ceará, onde pela sua diversidade sugere a existência de um mercado interno importante como avaliou Eni Samara: "A formação de mercados internos que contemplavam áreas econômicas exportadoras e núcleos urbanos em desenvolvimento vai criar também outras realidades sócioeconômicas que repercutirão diretamente no mercado de trabalho". ${ }^{56}$ Com isso o mercado de trabalho vai estar ligado a agroexportação.

A razão do declínio econômico do Ceará em relação ao Sul residiu na separação entre agroexportação e atividade manufatureira. Como mostrou Maria Izilda "um dos setores que ocupava um grande número de costureiras

\footnotetext{
${ }^{56}$ SAMARA, Eni de Mesquita. Lavoura Canavieira. São Paulo: Editora da Universidade de São Paulo, 2005, p.16.
} 
domiciliares eram as indústrias de sacaria para o café". 57

\subsection{A situação estacionária da agroexportação e a política de incentivos a instalação de manufaturas.}

Durante a seca de 1877-79 os principais setores da economia cearense: a pecuária e a agricultura foram duramente atingidas. Segundo o presidente José Júlio de Albuquerque Barros nos dois primeiros anos da estiagem houve uma extinção de $70 \%$ de todo o gado. Mas, observou ele que o "atraso da industria pastoril, não menos do que a falta de chuvas, concorreu para este resultado". ${ }^{58}$ Para corroborar sua afirmação ele lembrou que no Ceará os gados eram sujeitos às leis da natureza, soltos nos campos, confiados à mercê da providência divina e a fé pública. Não havia estabulação, não se preparava feno, nenhum abrigo contra as intempéries, nenhuma defesa contra os abatedores. Alguns currais, em que faziam a ordenha durante o inverno, um cercado em que se conservavam algumas pastagens, e a aguada, constituíam em geral, as benfeitorias de uma fazenda de criação.

A agricultura era realizada ainda se utilizando o sistema de queimadas que debilitava o solo. Raros fazendeiros e agricultores construíam açudes em suas propriedades ou algum outro tipo de reservatório de água como as cisternas. A forragem era exposta ao sol, perdendo seus nutrientes, e eram estragadas ao invés de aproveitadas pelos animais dentro dos cercados. O interessante do diagnóstico realizado pelo presidente José Júlio de Albuquerque Barros foi atribuir aos efeitos nefastos da seca o atraso da agricultura e da pecuária e a imprevidência dos agricultores e fazendeiros. Esse diagnóstico fora

\footnotetext{
${ }^{57}$ MATOS, Maria Izilda Santos. Cotidiano e Cultura: história, cidade e trabalho. Bauru, SP: EDUSC, 2002, p. 88.

${ }^{58}$ APEC - Fala com que o presidente da província do Ceará José Júlio de Albuquerque Barros abriu a $1^{\mathrm{a}}$ sessão da $24^{\mathrm{a}}$ legislatura, no dia $1^{\mathrm{o}}$ de novembro de 1878 , tipografia brasileira, p. 20.
} 
feito antes, em 1859, pela Comissão Científica de Exploração.

Apesar disso, Barros era um aliado do senador Pompeu e no seu relatório defendeu a construção de açudes e não a de cisternas como havia defendido o barão de Capanema. Por isso, ele não deixou de mencioná-lo como uma autoridade no que tange as secas. Ao destacar a defesa das matas lembrou que os "trabalhos a este respeito publicados pelo ilustrado senador Pompeu" eram "dignos da meditação de todos os cearenses". ${ }^{59}$ Por outro, lado o presidente fez no seu relatório de 1879 uma série de observações importantes acerca da economia cearense. O diagnóstico do presidente José Júlio até a grande seca foi que esta obliterou como de fato ocorreu o progresso econômico da província.

Apesar do atraso nas técnicas do amanho do solo, da precariedade do manejo do gado e da imprevidência dos sertanejos, vinha ocorrendo um melhoramento gradual desses setores. Segundo sua avaliação os agricultores vinham melhorando os seus engenhos e aparelhos de fabricação de açúcar e de destilação, as suas máquinas de preparar café e algodão, as suas fábricas de farinha de mandioca, "quando foram surpreendidos pelo terrível flagelo, que suspendeu quase toda a industria particular e causou danos irreparáveis por muitos anos". ${ }^{60}$ Essa é uma constatação importante, pois mesmo antes de terminar a seca já se avaliavam os danos com irreparáveis. O tempo mostrou que José Júlio se enganou porque em 1879, terceiro ano da seca, a indústria pastoril iniciou um contínuo processo de recuperação. (Vide gráfico 13, Cap. 1).

Essa afirmação equivocada de que após a seca a indústria pastoril não se recuperaria logo se juntou a uma outra a de que "A indústria

\footnotetext{
${ }^{59}$ APEC - Fala do presidente da província do Ceará José Júlio de Albuquerque Barros. $1^{\text {a }}$ sessão da $24^{\mathrm{a}}$ legislatura. Fortaleza: tipografia brasileira, $1^{\mathrm{o}}$ de novembro de 1878, p.22.

${ }^{60}$ Ibid., p.21.
} 
manufatureira está por criar na província”. Na opinião de Barros não havia um estabelecimento deste gênero que merecesse especial menção. As fábricas existentes na província ressentiam-se da falta de máquinas e aparelhos aperfeiçoados". Apesar disso, ele não pôde negar a existência de 2 fábricas de algodão e cigarros, 2 fundições, uma refinação de açúcar, uma fábrica de vinhos, aguardente e álcool dos frutos do país, algumas oficinas de serralheiros e outras artes mecânicas que vinham prosperando.

Parece-nos haver embutido no relatório do presidente uma perspectiva de redirecionamento da economia cearense. Observe-se que apesar de constatar um atraso técnico no manejo da agricultura e da pecuária ele não aponta medidas para corrigir esse problema. Porém para a atividade manufatureira ele formulou uma proposta clara "Logo que o estado financeiro melhorar, será, a meu ver, muito acertado proteger o estabelecimento de manufaturas, especialmente de fábricas de tecidos de algodão". ${ }^{1}$ Essa proteção à atividade manufatureira ocorreu porque houve incentivos à instalação de fábricas e oficinas por meio de uma política de subsídios.

Geraldo Nobre observou que, de certo modo, a prosperidade concorreu para fortalecer no Ceará, àquele tempo:

(...) a idéia de uma economia predominantemente agrícola e voltada para o comércio exportador, questão pacífica até à Grande Seca de 1877-1879, quando muitos perceberam que aumentara a vulnerabilidade à fatalidade climática, entre eles o engenheiro Pompeu Ferreira da Ponte, autor de um Plano Econômico de Irrigação da Província. ${ }^{62}$ [grifos do autor]

\footnotetext{
${ }^{61}$ Ibid.

${ }^{62}$ NOBRE, Geraldo da Silva. O processo Histórico de Industrialização do Ceará. Fortaleza: SENAI/DR-CE. Coordenadoria de Divulgação, 1989, p.87.
} 
Apesar de a produção agrícola ter sido marcada pela tranqüilidade e pelo otimismo da população ${ }^{63}$, dos bons números relativos à exportação de algodão, couros e borrachas existiam dois gargalos para essas indústrias, inclusive o café e o açúcar, para que prosperassem mais: o custo dos transportes e a falta de um estabelecimento bancário. Esses artigos enfrentavam dificuldades para chegarem ao principal mercado da província - Fortaleza. Quanto mais distante o local da produção, maior era o custo do transporte, aspecto que inviabilizava economicamente a atividade. Tomando-se como exemplo máximo, um produtor que transportasse açúcar, café, algodão e couros em 1872, a 250 km de distância, pagaria um frete relativamente alto para transportar essas mercadorias até Fortaleza:

TABELA 6

CUSTO COM TRANSPORTES - 1872

\begin{tabular}{|c|c|c|c|}
\hline Produtos & Preço da arroba & Frete & Lucro líquido \\
\hline Açúcar & 1.800 & 1.700 & 100 \\
\hline Café & 6.000 & 1.700 & 4.300 \\
\hline Algodão & 8.000 & 1.700 & 6.800 \\
\hline Couros & 8.500 & 1.700 & 6.800 \\
\hline
\end{tabular}

Apesar disso, a primeira metade do século XIX a prosperidade concorreu para fortalecer no Ceará, àquele tempo, a idéia de uma economia predominantemente agrícola e voltada para o comércio exportador, "questão pacífica até a Grande Seca de 1877-79, quando muitos perceberam que aumentara a vulnerabilidade climática, entre eles o engenheiro Pompeu Ferreira da Ponte, autor de um Plano Econômico de Irrigação da Província”. ${ }^{64}$ Essa percepção levou a uma mudança da política de progresso material para o Ceará ao longo da segunda metade do século XIX. Passou-se a centrar a política de

\footnotetext{
${ }^{63}$ CAMPOS, Eduardo. A Fortaleza Provincial: rural e urbana. Fortaleza: Secretaria de Cultura, Turismo e Desporto, 1988, p. 104.

${ }^{64}$ NOBRE, Geraldo da Silva. O processo Histórico de Industrialização do Ceará. Fortaleza, SENAI/DR-CE. Coordenadoria de Divulgação, 1989, p.87.
} 
desenvolvimento material da província na atividade manufatureira em detrimento da agricultura e da pecuária.

Em 1872 o presidente da província ressaltou a importância do estado promover algumas medidas necessárias ao melhoramento da província, como sejam - vias fáceis de comunicação, estabelecimentos bancários, reforma do porto - e "todo o auxílio do governo ao comércio, agricultura e indústria; porque, aparecendo isto, o tempo e a atividade dos cearenses fariam o mais." 65 Essas três atividades eram vistas de modo interligado. $\mathrm{O}$ que os presidentes reivindicam era investimentos e apoio financeiro por parte do governo para financiar a produção.

Nesse tempo existiram os "homens bons" como o governador Sampaio que apesar de ter sido um déspota ganhou a admiração de Capanema por tratar com justiça os pobres e os ricos. O apreço de Capanema pelo governador Sampaio se deveu em grande parte porque este não fazia política, algo muito diferente do que ele encontrou ao visitar as vilas, onde era envolvido nas disputas entre Saquaremas (conservadores) e Luzias (liberais). De acordo com ele "essas desavenças pela política só aproveitaram a especuladores, mas prejudicaram a população e mudaram-lhe os sentimentos". ${ }^{66}$

Nesse sentido, o senador Pompeu, apesar de ser um homem ponderado e culto, recorreu repetidas vezes ao seu amigo, o visconde de Sinimbú ${ }^{67}$, senador e ministro do Império, para apaziguar alguns ânimos ou

\footnotetext{
65 APEC - Relatório do presidente João Wilkens de Mattos. Tipografia Constitucional: Fortaleza, 20 de outubro de 1872, p.07.

${ }^{66}$ CAPANEMA, Guilherme Schüch. A Seca do Norte Rio de Janeiro: Imprensa Nacional, 1901, p.197.

${ }^{67}$ João Lins Vieira Cansanção de Sinimbú (visconde de Sinimbú) nasceu em Alagoas em 1810 no engenho Sinimbú. Formou-se em Direito pela Faculdade de Olinda e ocupou diversos cargos como: deputado estadual, ministro residente em Montevidéu, juiz de direito em Cantagalo (RJ), chefe de polícia do Rio de Janeiro e da Corte, presidente do Conselho de Mineração, presidente das províncias do Rio Grande do Sul e da Bahia e ministro dos Negócios Estrangeiros da
} 
afrontar outros. Em 1859 Sinimbú respondeu a uma carta de Pompeu a respeito de um pedido de mediação afirmando que faria o que estivesse ao seu alcance para corresponder à confiança com que ele e "seus amigos [lhe queriam] honrar". ${ }^{68}$ Assim, ajudar a um amigo, parente ou protegido era parte fundamental do modo como se fazia política no Brasil oitocentista.

O senador Saldanha Marinho remeteu uma carta ao Pompeu em 1863 na qual avaliava meio descontente, que até aquele momento, tinha-se lutado com o gabinete para que se tomassem em relação ao Ceará algumas medidas que trouxessem benefícios à província, mas nada se tinha conseguido. De acordo com ele se não era deliberada má vontade era a "mais estranhável das inércias". ${ }^{69}$ De fato, o Gabinete Conservador não tinha interesse em atender pedidos de parlamentares liberais.

Mas, apesar dos reclames, Pompeu e seus aliados tinham grande poder político na província, a ponto de conseguirem destituir do cargo um presidente como ocorreu em 1863. Em carta entregue pelo próprio senador Saldanha Marinho, Pompeu se dirigiu ao Marquês de Olinda, então presidente do Conselho de Estado e ministro do Império, do qual obteve a promessa da demissão do presidente da província do Ceará. ${ }^{70}$

A despeito do prestígio político que tinha o senador Pompeu, os conservadores como relatou o conselheiro Francisco Otaviano costumavam atacar o Ceará afirmando que aquele era o "país das barganhas e tratadas entre deputado e suplente, e como a terra onde os círculos foram regados com

Agricultura e da Justiça. Em 1878 após a morte súbita de Zacarias, Sinimbú foi chamado por D. Pedro II para chefiar o novo governo.

${ }^{68}$ CAMARA, José Aurélio Saraiva (org.). Carta do Visconde de Sinimbú, Rio de Janeiro, 23 de dezembro de 1859. Correspondência do Senador Pompeu. Fortaleza: Tipografia Minerva, 1960, p.80.

${ }^{69}$ Ibid., p.157.

${ }^{70}$ Ibid., p. 159. 
sangue". ${ }^{71}$ Essa assertiva, embora não fosse restrita ao Ceará, era perfeitamente verificável quando se observava o modo como manejava a política homens da categoria do senador Alencar, tido secretamente entre os seus pares como um energúmeno, aspecto este, que ele confirmou em alguns momentos de sua carreira política.

As queixas do senador Saldanha Marinho e do senador Pompeu eram em torno do envio de recursos à província. As experiências passadas mostraram que nos períodos de secas o governo central enviava recursos a título de socorros públicos. Antes da seca de 1877-79, houve uma tentativa de seca em 1864-65, como podemos depreender do relatório transcrito pelo cronista Alípio Luiz Pereira da Silva. Num trecho do relatório de um ministro do Império referente ao ano de 1865, no qual se lê que "em consequiência de prolongada seca que se manifestou em fins de 1864, o governo enviara para o Ceará gêneros alimentícios a fim de serem distribuídos pela população". ${ }^{72}$

Entretanto, essa seca é desconhecida entre historiadores e economistas cearenses, o que levou o cronista a uma explicação interessante sobre o seu esquecimento. Ele afirmou que isto aconteceu devido ao grande depósito de algodão que existia na província e a alta extraordinária que esse produto obteve. Alta esta devida à guerra civil norte-americana de Secessão (1861-65), que elevou o seu preço de 6 a 20 mil réis a arroba, e depois pela grande venda de escravos que se fez na província, logo que o governo imperial decretou a guerra contra o Paraguai, além da baixa do câmbio que favoreceu o comércio de couros, cera de carnaúba, produtos próprios dos tempos secos. ${ }^{73}$

Então, podemos inferir que a seca é o resultado da situação

\footnotetext{
${ }^{71}$ Ibid., p. 27.

${ }^{72}$ Ibid., p.69.

${ }^{73}$ Ibid, p.70.
} 
econômica e não da pluviometria. Porém, o importante nesse caso é observar que tanto a situação econômica era boa como também a pluviométrica. No primeiro ano (64) choveu 1.097 milímetros, distribuídos em 82 dias; e no segundo 1.233 milímetros distribuídos em 110 dias. ${ }^{74}$ De fato, em 1864 choveu menos que o costumeiro para os anos regulares, porém se comparamos esse ano com outros de perfil semelhante veremos que a relação dias chovidos/milímetros não explica a existência de uma seca em 1864-65.

GRÁFICO 23

RELAÇÃO DIAS CHOVIDOS/MILÍMETROS(1850-1874)

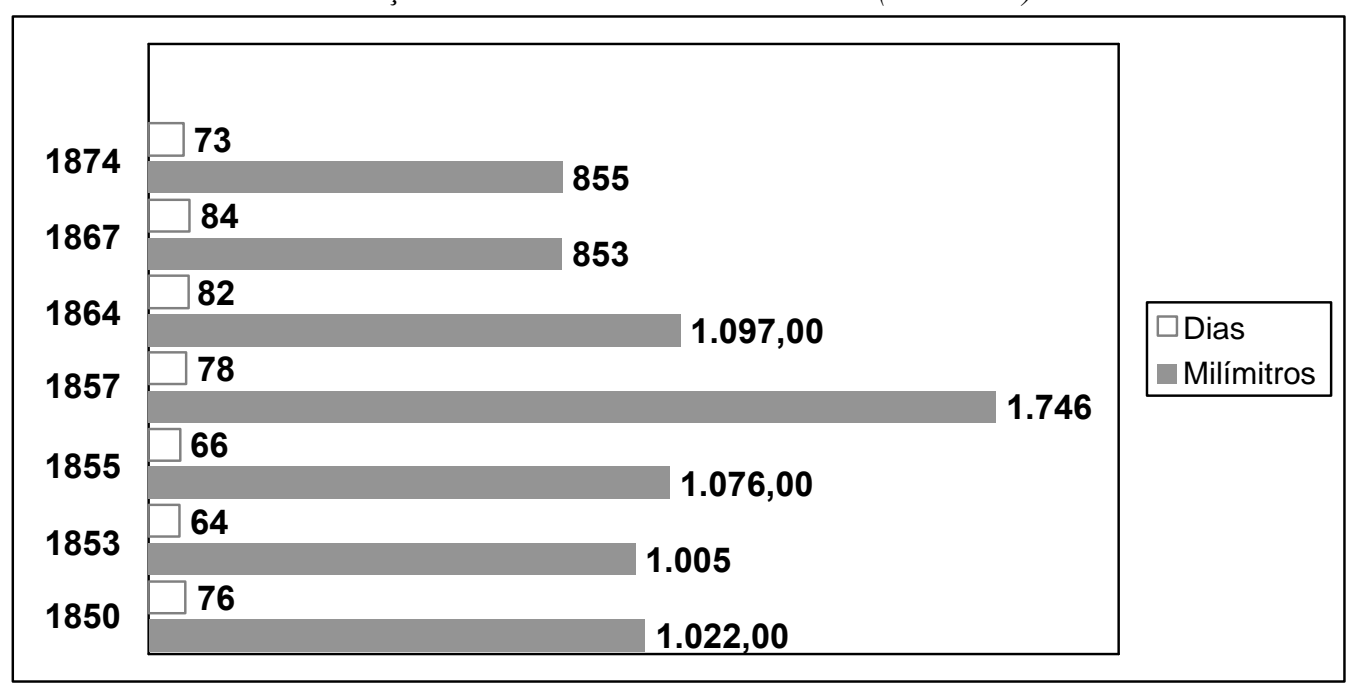

Fonte: TÉOFILO, Rodolfo. História das Secas no Ceará. Rio de Janeiro: Imprensa Inglesa, 1922, p. 12.

Porém, a explicação para que um ministro do Império tenha enviado gêneros à província como se houvesse uma seca reside na propensão do partido Liberal do Ceará capitaneado pelo senador Pompeu em utilizar os períodos de secas para a consecução do progresso material da província. Houve esforço político, mas faltaram as demais condições, assinaladas por Thomas Pompeu Sobrinho, para que a seca de 1864-65 se tornasse uma grande seca: fervor religioso, potencial econômico e balo dos valores morais, e devemos acrescentar

\footnotetext{
${ }^{74}$ TEÓFILO, Rodolfo. História das Secas no Ceará. (1877-1880). Rio de Janeiro: Imprensa Inglesa, 1922, p.12.
} 
um índice pluviométrico entre 400 e 600 milímetros e menos de 70 dias chovidos.

Quatro anos depois dessa malograda tentativa política de iniciar uma seca, o Senador Pompeu no seu discurso de 5 de outubro de 1869 avaliou as diferenças materiais entre as províncias do Norte e as do Sul, dizendo "O auxílio que, há certos anos a esta parte [Sul], o Estado tem prestado às províncias para favorecer o desenvolvimento de seu progresso material, e com que muito têm aproveitado, não tocou ao Ceará". ${ }^{75}$

Ele ensejava em seu discurso uma noção de estado que deveria promover um equilíbrio entre as províncias, ou ainda uma noção de integração, a partir da qual as províncias mais ricas e poderosas deveriam dispensar os favores do estado em prol das mais pobres. Porém, como ele mesmo constatou as mais aquinhoadas repartiam entre si os benefícios do estado, excluindo as províncias pequenas da partilha das riquezas. Essa noção ia de encontro à política imperial de investir nas províncias onde houvesse propensão ao desenvolvimento econômico.

O senador alegava em seu discurso, do alto da tribuna senatorial, que embora o Ceará e as províncias do Norte não recebessem os mesmos investimentos que as províncias do Sul, elas não eram “dispensadas do ônus, das pesadas contribuições de suor e sangue", ${ }^{76}$ referindo-se aos mais de seis mil homens mandados da província para lutar na Guerra do Brasil contra o Paraguai. Mas, ao Ceará, arrematou, dirigindo-se ao presidente do Senado, que tinha uma população livre superior a 500 mil habitantes e 116 léguas de costa marítima, não havia sido ainda concedido "um só dos grandes benefícios promotores, ou

\footnotetext{
${ }^{75}$ BRASIL apud NOBRE, 1989, p.57.

${ }^{76}$ Ibid.
} 
auxiliares da riqueza pública". ${ }^{77}$ Entre os benefícios observou que faltava ao menos uma estrada de ferro ou qualquer um desses melhoramentos materiais que tendiam a auxiliar o desenvolvimento da indústria, ao passo que as outras províncias tinham extensas linhas férreas, navegação costeira e fluvial, além de outros favores desta ordem em que o estado despendia centenas de milhares de contos.

Para equilibrar essas diferenças materiais a seca era o caminho a ser escolhido, por isso ao se referir às estiagens de 1792 e 1825, quando o povo desanimado, emigrou em direção às praias e às cidades, principalmente à capital, concorreu para o aumento dos preços e, por conseguinte do estado de miséria. Lamentou, no entanto, que a "imprudência do governo foi de não aproveitar o serviço: cometeu o grande erro de preferir dar ao povo esmola, em vez de serviço e salário". Com isso, a idéia de aproveitar a mão de obra abundante já estava colocada antes mesmo da seca de 1877-79. Lamentou Pompeu que o presidente da província fosse um homem de espírito acanhado, porque "consentiu na aglomeração de dezenas de imigrantes, que durante muitos meses viveram da distribuição diária de farinha, etc". ${ }^{78}$

De acordo com ele, apesar disso, em geral não morreu ninguém de fome, entretanto, concluiu que embora houvesse alimentos provenientes dos socorros públicos e particulares "a aglomeração de povos em habitações insuficiente fizeram logo desenvolver moléstias, que provocaram muitas vítimas". 79 Com isso, ele constatava o efeito maléfico da aglomeração de pessoas que desencadeava doenças que terminavam vitimando a população. Sua conclusão foi que a aglomeração da população e a distribuição de esmolas na

\footnotetext{
${ }^{77}$ Ibid.

${ }^{78}$ Ibid.

${ }^{79}$ Ibid.
} 
forma de farinha possibilitaram muitos abusos e a perda de um grande capital que poderia ter sido "aproveitado em obras públicas". 80

Se na seca de 1864-65 o senador Pompeu e os liberais cearenses não conseguiram por em prática a idéia de tirar proveito da seca para realizar obras públicas porque não havia as pré-condições necessárias para isso, na seca de 1877-79 essas condições estavam postas: capacidade política, migração, medo da seca e aguçado fervor religioso que aumentava à medida que o índice pluviométrico registrava pouquíssimas chuvas. Embora, o projeto já estivesse sendo executado um ano antes pelo presidente Caetano Estelita, um aliado do senador Pompeu, ele se tornou oficial com a mensagem do presidente do Conselho de Estado assinada pelo rei em 1878.

Com isso, o fator determinante para que a seca de 1877 pudesse ser chamada de "grande seca", alçada, portanto à condição de calamidade política foi o incentivo à migração de enormes contingentes populacionais do sertão em direção aos socorros públicos distribuídos no litoral. $\mathrm{O}$ fato do processo migratório para o litoral ter sido mais intenso nessa seca que nas estiagens anteriores, resultou não apenas de um abandono natural dos domicílios, mas da consecução planejada de um projeto político encabeçado pelas elites cearenses, ligadas ao partido liberal, que visavam à equiparação, em termos de progresso econômico, das províncias do Norte em relação às províncias do Sul. Por isso, como observou Tomaz Pompeu Sobrinho "os efeitos de uma grande seca dependem da capacidade política, do potencial econômico, do valor moral e até de um certo e correto fervor religioso da comunidade exposta ao flagelo clímico". ${ }^{81}$

\footnotetext{
${ }^{80}$ Ibid.

${ }^{81}$ SOBRINHO, Tomaz Pompeu. História das Secas (Século XX). 2a ed. Coleção Mossoroense,
} 
A capacidade política das elites deu à seca de 1877-79 a condição de "grande seca", diferenciando-as das demais elites do Norte. Durante a seca ocorreu a implementação do projeto de desenvolvimento econômico para o Norte formulado pelo Senador Pompeu, com o objetivo de equiparar as evidentes discrepâncias nos melhoramentos materiais que acirravam ainda mais as diferenças ideológicas e políticas, cindindo as duas regiões - Norte e Sul - em dois blocos antagônicos.

Essas diferenças materiais se inserem no processo de mudança do eixo econômico do Norte para o Sul em razão da decadência da agricultura dos produtos tradicionais cultivados no Norte: o açúcar, o tabaco e o algodão. ${ }^{82}$ Mas, no Ceará o esforço político de transformar a seca de 1877 numa "grande seca" foi o marco divisório entre as duas regiões do país, no que concerne ao território e a organização política. Com isso, os interesses locais e imediatos se sobrepuseram aos interesses nacionais.

O teatrólogo Artur Azevedo numa peça intitulada o "Rio de Janeiro em 1877" apresenta como personagens do prólogo algumas calamidades como a política, o boato, o beribéri, a morte e, como não poderia faltar, a seca e a inundação. Ele narra um interessante diálogo da política com a seca, diz: "Ò seca! A ti está reservado o mais importante papel entre as calamidades que hão de afligir a nação brasileira em $1877 "{ }^{83}$ Essa peça foi encenada em 1878 e teve como inspiração os acontecimentos mais importantes que atingiram o Brasil no ano anterior. Na peça ele rememorou que havia muitos anos que a seca não atingia a região. O personagem "a política" ordena que a seca parta e dissemine

vol. CCXXVI, 1982, p.8.

${ }^{82}$ PINTO, Virgílio Noya. Op. cit.

${ }^{83}$ AZEVEDO, Artur. Teatro de Artur Azevedo. Tomo I. Instituto Nacional de Artes e Ciências. INACEN, p.9. 
a fome e a miséria. Diz-lhe, ainda, que escolha para a sede de seu domínio uma província próspera e feliz. Então o personagem o boato, pai de todas as intrigas retruca: Goiás, por exemplo. Responde "a política”: não, o Ceará. ${ }^{84}$

Na contramão da política Guilherme Capanema endereçou em 1878 seus "Apontamentos sobre as secas do Ceará" escritos entre 1859 e 1861 ao Conselheiro João Lins Vieira Cansanção de Sinimbú, a época Ministro e Secretário de Estado dos Negócios da Agricultura, Comércio e Obras Públicas. Vê-se por isso que ele desconhecia as articulações políticas do grupo cearense junto ao visconde. Guilherme Capanema, tal qual Nicolau Maquiavel, escrevendo a César Bórgia, tentava aconselhar o príncipe a seguir suas orientações.

Contudo, as propostas feitas pelo senador Pompeu de aproveitar a mão de obra disponível durante as secas para realizar obras públicas embora não se referissem às províncias do Norte, mas apenas ao Ceará, foi adotada pelo Conselho de Estado e pelo governo do Império como parte do esforço de combate aos efeitos das secas nas províncias dessa região. Porém o barão de Capanema se opôs frontalmente a essa idéia porque segundo ele as secas no Norte eram:

[...] úteis debaixo de todos os pontos de vista; não são elas a causa das grandes calamidades, mas a imprevidência da gente, que não sabe tirar proveito da abundante produção de seu solo que as secas perpetuam. $\mathrm{O}$ país em que os pássaros voam assadinhos e temperados pelos ares ainda está para ser descoberto. ${ }^{85}$

Apesar das queixas o senador Pompeu reconhecendo que a despeito da falta de ajuda do estado, o Ceará avançava no seu progresso material,

\footnotetext{
${ }^{84}$ Ibid.

${ }^{85}$ BRAGA, Renato. História da Comissão Científica de Exploração. Fortaleza: Imprensa Universitária do Ceará, 1962, p. 294.
} 
vivendo, crescido e prosperado de maneira que atraía a "atenção nacional e até do estrangeiro". ${ }^{86}$ Não tem prosperado rápida e brilhantemente como o Pará, mas tem desenvolvido sua indústria mais permanente e solidamente, talvez porque sua prosperidade atesta não só o crescimento material de sua capital e das cidades centrais, como seu desenvolvimento comercial e marítimo demonstrado pelos mapas estatísticos da alfândega. ${ }^{87} \mathrm{O}$ processo de crescimento do Ceará foi tolhido momentaneamente pela grande seca de $1877-1879 .^{88}$

Em janeiro 1878 o visconde de Sinimbú assumiu a presidência do Conselho de Estado juntamente com o Ministério de Viação e Obras Públicas. Em fevereiro ele indicou uma Comissão de Engenheiros para de acordo com o presidente da província do Ceará João José Ferreira de Aguiar, "libertar algumas províncias do norte dos desastrosos efeitos das secas, que tão freqüentes vezes a torturam, nomeou uma comissão de engenheiros". ${ }^{89}$ Essa comissão, presidida pelo engenheiro e conselheiro Henrique de Beaurepaire Rohan, foi criada "a fim de estudar os meios mais eficazes de prevenir ou minorar os preditos efeitos". 90

No entanto, Aguiar se equivocou ao afirmar que essa comissão veio à província estudar os meios mais eficazes de prevenir e minorar os efeitos das secas. A Comissão de Engenheiros que chegou ao Ceará no dia 13 de fevereiro de 1878 era diferente da Comissão Científica de Exploração que visitou a região em 1859 porque enquanto aquela visitou pessoas e lugares, fazendo uma análise política, econômica, social e cultural do problema material, esta já veio trazendo a idéia pronta de combate às secas por meio da construção de grandes açudes e

${ }^{86}$ NOBRE, Geraldo da Silva. O processo Histórico de Industrialização do Ceará. Fortaleza, SENAI/DR-CE. Coordenadoria de Divulgação, 1989, p.57.

${ }^{87}$ Ibid.

${ }^{88}$ Ibid., p. 75.

${ }^{89}$ APEC - Relatório com que o Conselheiro João José Ferreira de Aguiar passou a administração da província do Ceará ao Dr. Paulino Nogueira Borges da Fonseca, $3^{\circ}$ vice-presidente da mesma província em 22 de fevereiro de 1878, p.8.

${ }^{90}$ Ibid. 
estradas de ferro. ${ }^{91}$ Seus estudos se circunscreveram as escolhas locais mais adequados à execução dessas obras. Nada mais era de se esperar de uma comissão de engenheiros.

Entre as propostas feitas pelos engenheiros estava a instalação de uma empresa ferroviária no Ceará que desde a década de 60 do século XIX, era um anseio do senador Pompeu e da sua família. No Brasil a primeira estrada de ferro foi a D. Pedro II ligando o Rio de Janeiro a cidade paulista de Cachoeira em 1855. Essa estrada foi construída quando já estava em vigor a lei n.641 de 26 de junho de 1852 que concedia garantia de juros de $5 \%$ por cento sobre o capital empregado, mas $2 \%$ por cento concedidos pelo governo provincial. Segundo Eric J. Hobsbawm ${ }^{92}$ os caminhos de ferro no século XIX possibilitaram o escoamento da produção industrial das fábricas aos portos.

Era ponto comum entre os liberais do Ceará que se a província não recebesse recursos para a consecução de estradas de ferro o seu progresso ficaria comprometido. Entretanto, no Ceará as estradas de ferro de Baturité e de Sobral vão estar ligadas não apenas a atividade econômica, mas a uma concepção estratégica de socorros públicos durante as secas, pois, como vimos anteriormente, o modelo assistencialista presente no projeto Pompeu Sinimbú se baseou no apóio à migração e no ao abandono dos domicílios. E apesar do senador Pompeu ter afirmado ao presidente do senado que as estradas de ferros promoviam o progresso material, as estradas de ferro de Baturité e Sobral tiveram um papel diferente.

Os estudos iniciais relativos à estrada de ferro de Baturité

91 APEC - Relatório com que o Conselheiro João José Ferreira de Aguiar passou a administração da província do Ceará ao Dr. Paulino Nogueira Borges da Fonseca, $3^{\circ}$ vicepresidente da mesma província em 22 de fevereiro de 1878, p.8.

${ }_{92}$ HOBISBAWN, Eric. J. A Era dos Impérios. Rio de Janeiro: Paz e Terra, 1998, p.60-61. 
começaram em 1868, a cargo do engenheiro Francisco Antonio Pimenta Bueno. Nesse período, antes de se lhes assentarem os trilhos de ferro foi necessário à construção de diversas pontes sobre os seus diversos cursos d'água como os rios Acarape, Guaiúba, Pacotí e Potiú. Pontes metálicas foram encomendadas da Europa e guardadas num depósito num sítio localizado no Benfica. O engenheiro mandado pelo governo Imperial era contra o investimento e o envolvimento da província naquela obra, que já havia comprado 200 milheiros de tijolos e 703 alqueires de cal, opinando que se entregasse a uma empresa particular, o assentamento dos seus trilhos, pois a "produção que se escoa pela estrada exige melhoramentos dessa ordem". ${ }^{93}$

Existia já firmado com os engenheiros John James Foster e José Pompeu de Albuquerque Cavalcante (o engenheiro chefe da direção de obras públicas), um contrato para a organização de uma Companhia que explorasse a construção de uma via-férrea pelo sistema tran-road de Fortaleza até a povoação de Pacatuba com ramal na vila de Maranguape. Esse contrato, dependente da aprovação da Assembléia Provincial, garantiria juros de $5 \%$ por cento a Companhia.

Mas, as elites das províncias do Norte, mormente as do Ceará, encontraram num fenômeno climático da natureza - a seca - o motivo político para pleitear a remessa de recursos do Império com o objetivo de atender aos retirantes. Em 1878 quando a seca açoitava as províncias do Norte, o Gabinete Sinimbú aprovou um crédito de 9 mil contos de réis para o pagamento e resgate da estrada de ferro de Baturité e das despesas do seu prolongamento até Canoa como também da construção da estrada de ferro de Sobral e de Paulo Afonso.

\footnotetext{
93 APEC - Apensos ao Relatório do presidente João Antonio de Araújo Freitas Henriques. Tipografia Constitucional: Fortaleza, 1 de setembro de 1869, p.17.
} 
Estas obras tinham como objetivo principal atender as vítimas da seca, a respeito das quais conclui Rodolfo Teófilo, "deviam ser aproveitados milhares de braços, que viviam ociosos, infelizes que mendigavam, veria impedir e emigração". 94

$\mathrm{Na}$ seca de 1877 o jornal Cearense ligado ao partido liberal se debatia com o Pedro II, jornal conservador. O Cearense retrucava "Não há seca, dizem os dois órgãos conservadores e, entretanto a fome e a miséria vão assolando horrivelmente. Do interior começam a chegar emigrantes acossados pela miséria". ${ }^{95}$ Nesse sentido, a chegada dos imigrantes era uma confirmação da seca. No entanto, o que o jornal não dizia era que essa imigração crescente se devia ao fato do presidente Caetano Estelita ter realizado a distribuição antecipada de socorros públicos.

A imprensa liberal e a distribuição de socorros antecipados criaram as pré-condições para que a seca fosse declarada. Após o dia 19 de março observou Rodolfo Teófilo que estava “declarada a seca! O pânico apoderou-se de todos os espíritos. A noite muitos pobres se recolhiam à casa e amedrontados com suas famílias falavam em emigrar". ${ }^{96}$ Com a decretação oficial da seca se intensificou a migração do sertão em direção ao litoral, colocando a população na situação de dependência em relação em relação ao governo da província. A província por sua vez passou a depender do governo central. Com isso, a desigualdade econômica entre o Norte e Sul não se deu em razão da forma de colonização, mas da consecução de um projeto político econômico elaborado pelas próprias elites da região que teve a seca, enquanto calamidade política, como vértice.

${ }^{94}$ TEÓFILO, Rodolfo. História das Secas no Ceará. Rio de Janeiro: Imprensa Inglesa, 1922, p.201.

${ }_{95}$ BPMG - jornal Cearense, 1877, p.2.

${ }^{96}$ TEÓFILO, Rodolfo. Op. cit., p.80-81. 
Contudo, o índice pluviométrico, a queda da atividade econômica e o crescimento populacional não são suficientes nem para explicar a razão da seca de 1877-79 ter sido chamada de "grande seca", nem a inversão calamidade natural versus calamidade política. Para respondermos a razão disso, teremos que considerar a conjuntura econômica na qual se inseriu o Ceará e o Norte em relação ao Brasil, na segunda metade do século XIX. Celso Furtado assinalou que se considerada em conjunto, a economia brasileira alcançou uma taxa de crescimento, relativamente alta, na segunda metade do século XIX. Contudo, ele atribuiu esse fator ao comércio exterior, considerado o setor dinâmico do sistema, o processo de crescimento nessa etapa. ${ }^{97}$

Então já na presidência do Conselho da Coroa o visconde de Sinimbú dirigiu uma mensagem ao monarca na qual ele contextualizava o problema, tratando a seca como uma calamidade que atingia as províncias do Norte há quase dois anos. O conselho de Estado enviou uma mensagem ao rei juntamente com um decreto para ele assinar. A mensagem foi assinada por João Lins Vieira Cansanção de Sinimbú, Lafayete Rodrigues Pereira, Carlos Leôncio de Carvalho, Barão de Vila Bela, Gaspar da Silveira Martins, Marquês de Herval e Eduardo de Andrade Pinto, aliados políticos do senador Pompeu com alguns dos quais, antes de morrer, manteve intensa correspondência.

A Mensagem do Conselho de Estado começava com um breve histórico dos anos de secas observando as circunstancias calamitosas que estavam "passando as províncias do Norte causadas pela seca que, há quase dois anos as devastava". ${ }^{98}$ Nesse período o Governo Imperial tinha se esforçado empregando todos os meios de que dispunha "para aliviar os sofrimentos dos

\footnotetext{
${ }^{97}$ Ibid., p.206.

${ }^{98}$ Ibid.
} 
habitantes daquela parte do Império". 99

Os signatários da mensagem observaram ao rei que os socorros vinham sendo prestados por meio de remessas freqüentes de gêneros alimentícios, alguns importados do exterior para as províncias. O transporte de gêneros era feito por cabotagem devido aos meios de transporte que se limitavam aos portos marítimos ou fluviais a que podiam chegar navios a vapor e à vela, pois havia dificuldade de condução para o interior, em razão da quase absoluta falta de animais que pereceram pelos efeitos da seca.

Com isso, os signatários da proposta afirmaram que a maioria da população pobre estava impossibilitada de receber nos lugares da sua residência, os subsídios do estado, e por isso afluíam ao litoral, onde provocando graves prejuízos à saúde pública e perturbando a regularidade do serviço de distribuição dos socorros públicos, achava-se "acumulada, inutilizando, na inércia, a atividade que, bem aproveitada, produziria resultados de incontestado valor". 100

Esse e o início do processo de diferenciação entre o Norte e o Sul, pois de acordo com Evaldo Cabral de Mello ${ }^{101}$ no século XIX o Brasil Imperial era divido basicamente em Norte e Sul, mas de 1830 a 1870 essa divisão não implicava numa diferenciação regional, pois no aspecto econômico e político os interesses eram convergentes, havendo em certa medida homogeneização. Mas, o período correspondente aos anos sitos entre 1870 e 1889 foi marcado por acentuada diferenciação entre essas duas regiões.

Pode-se dizer que a seca foi o elemento determinante dessa diferenciação. Ou melhor, o modo como o governo provincial lidou com o

\footnotetext{
${ }^{99} 100$ Anos da RVC. 1870-1970. Notícias. Edição Centenária, Fortaleza, (s/e), 1970, p.3-5. ${ }^{100}$ Ibid.

${ }^{101}$ MELLO, Evaldo Cabral de. O Norte Agrário e o Império: 1871-1889. Rio de Janeiro: Nova Fronteira; Brasília: INL, 1984, p.
} 
problema. Assim, a disparidade econômica entre o Norte e o Sul do Brasil não resultou de crise contínua dos produtos tradicionais, haja vista sua crescente produção, mas da aplicação da proposta do senador Pompeu de utilizar a mão de obra disponível durante as secas para a realização do progresso material do Ceará.

Esse processo de diferenciação se acentuou com a crescente disputa política entre liberais e conservadores. Nesse sentido, Raimundo Faoro afirmou, com razão, que toda história do Brasil Império poderia ser dividida entre duas ideologias principais, discordantes ao longo dos anos: o centralismo contra o liberalismo localista, o federalismo contra o unitarismo ou a democracia contra a monarquia. Com isso, o país na segunda metade do século XIX enfrentava o debate em torno da centralização versus descentralização política.

As províncias reivindicavam maior autonomia em relação ao poder do rei e quase todas as críticas liberais contra o governo imperial tinham por trás a defesa dos interesses provinciais em face do absorvente poder central. Por isso, o manifesto republicano de 1870 defendia a exigência federativa como princípio cardeal, e Rui Barbosa, ao que parece dava mais importância à solução federativa que a republicana ao afirmar o seu desejo de "federação com ou sem república”. 102

Com a queda do Ministério Zacarias resultante do desentendimento entre o político baiano Zacarias de Góes e Vasconcelos e o Imperador D. Pedro II, teve início em 1868 o gabinete conservador do visconde de Itaboraí que repercutiu nos cenários políticos locais favorecendo os conservadores e eclipsando os liberais. O fracasso dessa vertente progressista desencadeou

\footnotetext{
${ }^{102}$ SALDANHA, Nelson. História das Idéias políticas no Brasil. Brasília (Senado Federal), Conselho Editorial, 2001, p.243.
} 
descontentamentos com o regime monárquico. Capistrano de Abreu anotou que Zacarias até o fim da vida não perdeu ocasião para "lacerar ou morder D. Pedro II".

O Imperador por sua vez, acrescentou em tom de ironia, somente chamou os liberais ao poder apenas depois de "Zacarias bem enterrado no cemitério do Catumbi”. ${ }^{103}$ Para Pandiá Calógeras “a verdade real parece estar no fato de que Zacarias nunca fora um estadista". ${ }^{104}$ De fato, durante esse período os políticos liberais amargaram o ostracismo de dez anos, até que em 1878 assumiu um ministério liberal presidido por João Lins Vieira Cansanção de Sinimbú.

Nesse interregno houve a expansão das idéias descentralizadoras e republicanas, pois se passou a defender crescentemente que as províncias deveriam ter as suas próprias instituições locais, apropriadas às suas circunstâncias e condições peculiares. Com isso, através das suas oligarquias, elas passaram a se opor e a pleitear regimes diferenciados, procurando distinguirem-se entre si as grandes das pequenas, as do centro das do litoral, as do Norte das do Sul, observando-se a diversidade de zonas, de climas, de produções, de características e interesses que conviriam à separação uma da outra. Com isso o Brasil, fez-se regional antes mesmo de se tornar nacional. Essa perspectiva regionalista ocorreu de modo paulatino, a partir do entrechoque de interesses entre as elites políticas, que no Império se dividiam em duas grandes forças partidárias: os liberais e os conservadores.

A diferença entre liberais entre liberais e conservadores residia

\footnotetext{
103 ABREU, Capistrano de. "Fases do Segundo Império". Revista do Instituto Histórico e Geográfico do Brasil. Rio de Janeiro, 1998, p.432-445.

${ }^{104}$ CALÓGERAS, Pandiá. Formação Histórica do Brasil. $5^{a}$ ed., São Paulo: Nacional, 1957, p.342.
} 
simplesmente no fato dos primeiros defenderem a descentralização monárquica e dos segundos a centralização. Porém os liberais ao defenderem a descentralização defendiam os seus próprios interesses oligárquicos. ${ }^{105}$ É nesse sentido que devemos entender o fato, como destacou José Borzacchiello, da região Nordeste do século XIX à primeira metade do século XX, ter tido sua imagem associada ao semi-árido. Este aparece nos discursos das elites políticas governamentais, como "responsável pelos problemas regionais, dado que culmina na elaboração, em escala nacional e regional, de um imaginário social fundado no clima, responsável pelo atraso da região”. ${ }^{106}$

No entanto, isso como sabemos decorreu da consecução de um projeto de assistência aos desvalidos que estabeleceu como notou Zulmira Tavares "As linhas do curso migratório contínuo, sempre mais para o Norte, para as serras (onde ainda se encontravam olhos d'água, as nascentes vivas) ou para o litoral, passavam por Sobral no período, parada temporária ou definitiva, pois oferecia aos retirantes possibilidades de trabalho". ${ }^{107}$ Essas diretrizes foram estabelecidas pelo projeto Pompeu Sinimbú como veremos no capítulo 4.

No entanto, Celso Furtado e a sua perspectiva de explicação externa da formação da economia brasileira desconsidera os aspectos históricos internos. Segundo José Sérgio Rocha Gonçalves o modelo explicativo elaborado por Celso Furtado da formação da economia nacional estabeleceu "uma distinção rígida" entre um setor agroexportador (tradicional) e um setor industrial

\footnotetext{
${ }^{105}$ LIMA, Heitor Ferreira. História do pensamento econômico no Brasil. São Paulo: Nacional, 1976, p.117. Nesse trabalho o autor aborda a natureza do liberalismo econômico no Brasil do século XIX, indicando como a política monetária entravou a nascente iniciativa industrial. Essa é uma das melhores análises sobre o assunto.

106 SILVA, José Borzacchiello da, DANTAS, Eustógio Wanderley Correia, ZANELLA, MEIRELES, Antonio Jeovah de Andrade. (orgs.) Litoral e Sertão: natureza e sociedade no Nordeste brasileiro. Fortaleza: Edições Demócrito Rocha (Coleção Estudos Geográficos), 2006, p.23.

${ }^{107}$ TAVARES, Zulmira Ribeiro. Rembrants e Papangus. In: Roberto Schwarz (org.). Os pobres na Literatura Brasileira. São Paulo: brasiliense, 1983, 55.
} 
(dinâmico)". ${ }^{108}$ Ao fazer isso Furtado se "afasta da História, isto é, desconsidera o próprio processo histórico de acumulação de capital e de formação de uma estrutura capitalista no Brasil" ${ }^{109}$ onde o setor agrário exportador (cafeeiro) e o setor industrial foram interdependentes.

Por outro lado, a transição da agroexportação para a atividade manufatureira desconsiderou a importância da lavoura e da pecuária para o pequeno lavrador, para o roceiro dono de um pequeno pedaço de terra e com poucos recursos. Mas, a pior conseqüência da política manufatureira foi a fragilização da economia de subsistência, o setor mais durante atingidos pelas secas.

IMAGEM 1: Agricultor à rabiça de seu cultivador

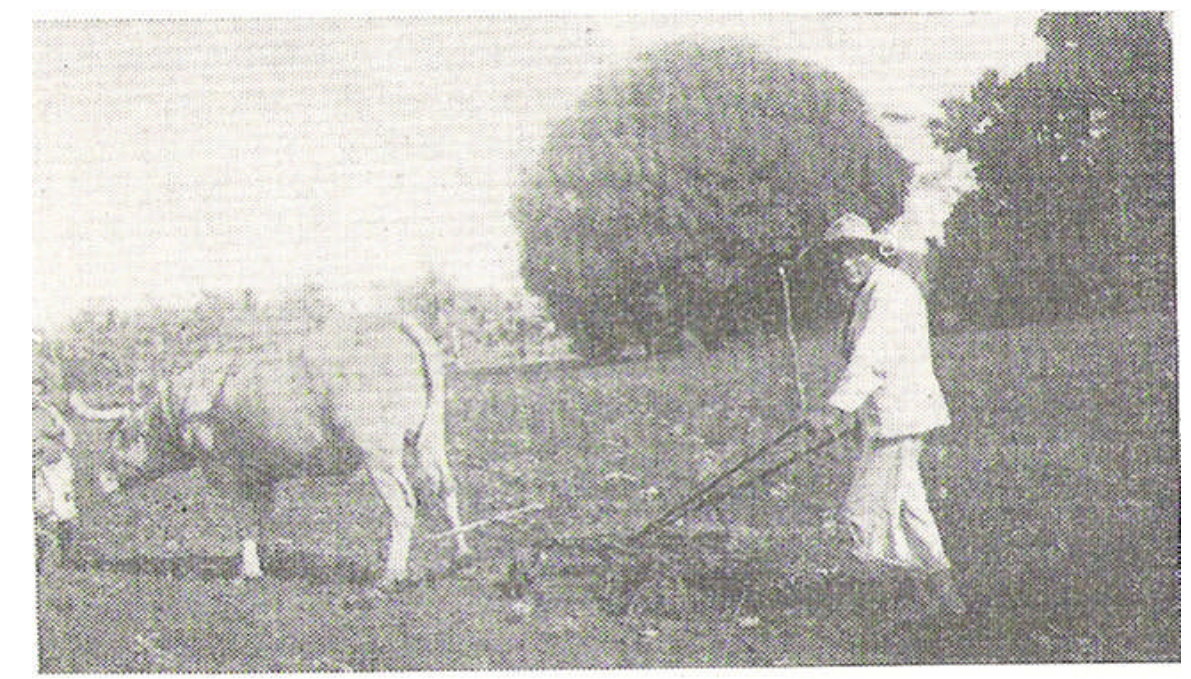

Fonte: SOUSA, José Bonifácio de Sousa. Quixadá: de fazenda a cidade. IBGE, Conselho Nacional de Estatística, 1960, p.135.

Em 1895 Antonio Bezerra de Menezes descreveu a conjuntura fabril da cidade de Fortaleza. De acordo com ele havia na capital cearense duas fábricas de fiação e tecelagem, uma inaugurada no início de 1883 por Antonio Pompeu de Sousa Brasil, a que se associaram Tomás Pompeu de Sousa Brasil e

\footnotetext{
${ }^{108}$ FURTADO, Celso. Teoria do Desenvolvimento Econômico. $2^{\mathrm{a}}$ ed. São Paulo: Nova Cultural, 1986, p. X.

${ }^{109}$ Ibid.
} 
Antonio Pinto Nogueira Acióli. O capital empregado era de 380 mil réis e a fábrica produzia 1.200.000 jardas de fazenda algodão, mantendo em 1895, 215 operários. A outra fábrica fundada em 1889 por Holanda, Gurjão \& Cia. à mesma rua com o capital de 250:000\$000 e empregava 160 operários. Havia ainda uma fábrica de meias, fundada em 1894 com um capital de 150:000\$000 e nesse mesmo ano foi fundada uma fábrica de Curtume na Jacarecanga com capital de 300:000\$000. Essa fábrica produzia 25.000 meios de sola e 70.000 peles de chagrin, marroquim, camurça e por ano e empregava 64 operários. ${ }^{110}$

Mas, de acordo com a Corografia do Estado do Ceará organizada com base nos trabalhos do senador Tomás Pompeu de Sousa Brasil e publicada em 1905 a indústria manufatora carecia de incremento. Na exportação para a Europa e Estados Unidos da América, continuava figurando apenas: borracha, cera, algodão, sola, couros preparados, courinhos, caroço de algodão, ossos, etc. O comércio para os Estados Unidos, especialmente para os do Norte, consta destes principais artigos: queijos, velas de carnaúba, chapéus de palha, vinho de caju, redes, doces de goiaba, macarrão e sabão. O vinho de caju sem álcool é uma industria que se tem desenvolvido muito.

No Estado existem cinco fábricas de fiação de tecidos: três na capital, uma em Sobral e outra em Aracati; duas fábricas de rede na capital, além de mais de trezentos teares esparsos: uma fábrica de macarrão de massas alimentícias; diversas fábricas de cigarros, refinação de açúcar e destilação, outras de cal-marmóreo, mosaicos, sabão, sabonetes; até moinhos para o preparo de farinhas. O Ceará importa ainda quase todos os objetos manufaturados, como sejam vinhos, cerveja, licores, tecidos, e até cereais.

\footnotetext{
${ }^{110}$ MENEZES, Antonio Bezerra de Menezes. Descrição da Cidade de Fortaleza. Fortaleza: Edições UFC/Prefeitura de Fortaleza, 1992, p.181.
} 
$\mathrm{O}$ esforço em fazer progredir o setor manufatureiro ocorreu em detrimento da agricultura e da pecuária estacionaram tecnicamente. O naturalista Alberto Loefgren observou em 1911 que "uma indústria pastoril sobre base econômica ainda não se desenvolveu no Ceará, apesar de possuir não só excelente gado, como também pastagens naturais de primeira ordem e ser essa indústria talvez a base principal de toda a vida comercial do Ceará”. ${ }^{111}$ Essa nova política, no entanto, se assentou na seca e na idéia de que ela representava um óbice ao progresso da região. Isso ocorreu porque depois de 1877 houve uma mudança no pensamento e na política econômica que transitou da agroexportação para uma política de incentivo a instalação de oficinas manufatureiras.

Entretanto, antes da seca de 1877 a agroexportação e atividade manufatureira eram setores interdependentes, sobretudo com a política iniciada em 1836 pelo presidente José Martiniano de Alencar de importar máquinas e modelos atinentes à modernização da lavoura. Nesse sentido, João Manoel Cardoso de Melo acerta ao dizer que o desenvolvimento do Brasil foi tardio e não desigual como afirma o pensamento furtadiano-cepalino. Nesse caso, o carro chefe da industrialização - São Paulo - dependeu dos capitais da economia cafeeira para se desenvolver. Em relação ao Ceará a questão é a mesma, ao invés de se explicar o atraso da província em relação a São Paulo, procuramos explicá-la a partir de mudanças internas como a que ocorreu em relação à política econômica assentada até a seca de 1877 na agroexportação para a atividade manufatureira.

Essa mudança de perspectiva implicou num estacionamento da

\footnotetext{
${ }^{111}$ LOEFGREN, Alberto. Ceará: notas botânicas. Revista do Instituto Histórico e Geográfico do Ceará. Tomo XXV, 1911, p.162-163.
} 
lavoura de exportação e na fragilização da lavoura de subsistência, tornando a economia e a população cearense mais sujeita aos efeitos das intempéries. O responsável por essa mudança foi o partido liberal cearense capitaneado pelo senador Tomás Pompeu que conseguiu, ao estabelecer a noção da seca como óbice ao progresso material da região, mudar o pensamento econômico centrado na agroexportação para a atividade manufatureira. Com isso, explicamos o atraso do Norte em relação ao Sul a partir das mudanças políticas e econômicas ocorridas internamente e não a partir da perspectiva externa fulcrada na noção de desenvolvimento desigual.

$$
* * *
$$

Com a eclosão da seca de 1877-79 houve se interrompeu a política de combate à violência no sertão, a agropecuária entrou em descrédito e por isso se tentou dar um salto para a atividade manufatureira. Porém, o descolamento entre agroexportação e manufatura condenou o Ceará ao atraso econômico em relação às províncias do sul do país. A adoção dessa política econômica equivocada fragilizou a agricultura de subsistência, o setor mais fortemente atingido durante as secas. Além disso, o mercado interno de trabalho agrícola se ressentiu da falta de incentivo por parte do governo. 


\section{Capítulo 4 - Projeto Pompeu Sinimbú: diretrizes para o progresso do Norte, 1869 - 1905.}

Nesse capítulo mostraremos que a naturalização da violência, o soerguimento da seca como calamidade principal e a mudança da política econômica, a partir da seca de 1877, tiveram como pano de fundo o que denominamos de projeto Pompeu Sinimbú. Este consistiu inicialmente na proposta defendida pelo senador Pompeu em 1869 de se utilizar a mão de obra disponível durante as secas para a realização de obras públicas. Essa proposta foi implantada durante a seca de $1877-79$ e nas secas seguintes. Com a ascensão do visconde de Sinimbú a presidência do Conselho de Estado a proposta do senador ganhou status de projeto.

\section{1. - Socorros públicos Indiretos.}

Durante a seca de 1877-79 foi implementada a proposição do senador Pompeu feita em 1869 de se utilizar a mão de obra disponível durante as secas para a realização de obras públicas (socorros indiretos). Nesse sentido, a mensagem dirigida a d. Pedro II pelo presidente do Conselho da Coroa, o visconde de Sinimbú, seguiu a proposta do senador. O eixo fundamental do projeto era:

Tirar vantagem da própria desgraça, empregando em trabalhos úteis tantos braços ociosos; estabelecer um sistema de serviço que sobre assegurar a essa população meios de subsistência, alimente seu amor ao trabalho, mediante razoável gratificação; tal é, Senhor, o pensamento fundamental do projeto que os Ministros de Vossa Majestade Imperial 
não hesitaram em preferir o da construção de estradas de ferro, que partindo de um porto navegável se prolonguem pelo interior, na direção de cidades e vilas já fundadas e dos centros produtores. [grifos nossos] ${ }^{1}$

Assim, estavam colocadas as diretrizes para a política de desenvolvimento das províncias do Norte. A realização de algumas dessas obras como estradas de ferro, açudes e pontes não tiveram total utilização econômica por não conseguirem ligar os centros produtores. Por isso, o aspecto mais importante desse projeto de desenvolvimento foi que ele partiu de fora para dentro. Tomando-se o conceito de desenvolvimento econômico de Joseph A. Schumpeter, observa-se que ele entendia “por 'desenvolvimento', portanto, apenas as mudanças da vida econômica que não lhe forem impostas de fora, mas que surjam de dentro, por sua própria iniciativa". ${ }^{2}$

O projeto Pompeu Sinimbú nesse quesito não previa a iniciativa particular e as obras empreendidas eram executadas pelos comissários de socorros que empregavam trabalhadores desvalidos, cujo pagamento na maior parte era feito com ração. Observou Celso Furtado que o "desenvolvimento deriva o seu impulso primário" de alguns aspectos internos da economia como modificações no perfil da demanda, assimilação do progresso tecnológico, ou a combinação desses dois fatores. ${ }^{3}$ Além desses aspectos, devemos observar a importância que tinha no século XIX, a mão de obra abundante para o desenvolvimento material das províncias. O projeto Pompeu Sinimbú se baseou na mão de obra abundante, mas faltaram os outros fatores.

\footnotetext{
${ }^{1}$ Mensagem do Conselho de Estado. In: 100 Anos da RVC. 1870-1970. Notícias. Edição Centenária, Fortaleza (s/e), 1970, pp.3-5.

${ }^{2}$ SCHUMPETER. Joseph A. A Teoria do Desenvolvimento Econômico. São Paulo: Abril Cultural, 1982, p.47.

${ }^{3}$ FURTADO, Celso. Raizes do subdesenvolvimento. Rio de Janeiro: Civilização Brasileira, 2003, p.175.
} 
O projeto Pompeu Sinimbú teve como alvo não o socorro aos desvalidos das secas, mas a utilização da mão de obra disponível. Essa mão de obra não era nem escrava nem de regime de meação: era assalariada, como fora prevista originalmente no projeto. Em 1889 os operários empregados na elevação do aterro da Lagoa da Pajussara receberam diárias pelo trabalho realizado do dia 25 de fevereiro ao dia 2 de março.

TABELA 7

FOLHA DOS OPERÁRIOS EMPREGADOS NO SERVIÇO DE ELEVAÇÃO DO ATERRO DA LAGOA DA PAJUSSARA NO CEARÁ(1889)

\begin{tabular}{l|lllll}
\multicolumn{5}{|c}{ DO ATERRO DA LAGOA DA PAJUSSARA NO CEARÁ(1889) } \\
\hline $\mathrm{N}$. & Empregos & Nomes & Dias & Diárias & Total \\
\hline 1 & encarregado & Aurélio Gaspar de Oliveira & 06 & 3.000 & 18.000 \\
2 & operários & Francisco de Paula Jathay & 06 & 800 & 4.800 \\
3 & & Ludgero Soares & 06 & 800 & 4.800 \\
4 & & Vicente Lopes & 06 & 800 & 4.800 \\
5 & & Isidoro Ferreira da Silva & 06 & 800 & 4.800 \\
6 & & Lazaro de Sousa & 06 & 800 & 4.800 \\
7 & & Luiz Pereira da Costa & 06 & 800 & 4.800 \\
8 & & Rogério Caetano & 05 & 800 & 4.000 \\
9 & & Jesuíno de Lira & 05 & 800 & 4.000 \\
10 & & Antonio Fausto de Figueiredo & 04 & 800 & 3.000 \\
11 & Antonio Rodrigues do Nascimento & 02 & 800 & 1.600 \\
12 & Adriano Ferreira de Lima & 03 & 800 & 2.600 \\
13 & & Manoel Cipriano & 03 & 800 & 2.600 \\
14 & Antonio Batista & 04 & 800 & 3.200 \\
15 & João Batista & 03 & 800 & 2.600 \\
16 & Joaquim Pereira de Queirós & 06 & 1.500 & 9.000 \\
\hline 17 & Feitor & Manoel Alves da Silva & & \\
\hline Fonte: APEC - Comissões de Socorros Públicos da Pajussara, 1889. & &
\end{tabular}

Essa folha de pagamento dos operários custou 83 mil réis. Ela, no entanto é apenas um exemplo do ocorria no Ceará durante as secas e que o transformava num canteiro de obras. Com isso, havia aumento da renda monetária e o agricultor meeiro se transformava em operário assalariado. Esses operários além das diárias recebiam também um socorro em ração. Com isso, o estado passou a comprar gêneros básicos para a alimentação da população, o que inflacionou o mercado e levou as áreas de cultura de exportação a produzirem gêneros de primeira necessidade, por se tornarem mais lucrativos. 
IMAGEM 2: Planta para a construção de um açude.

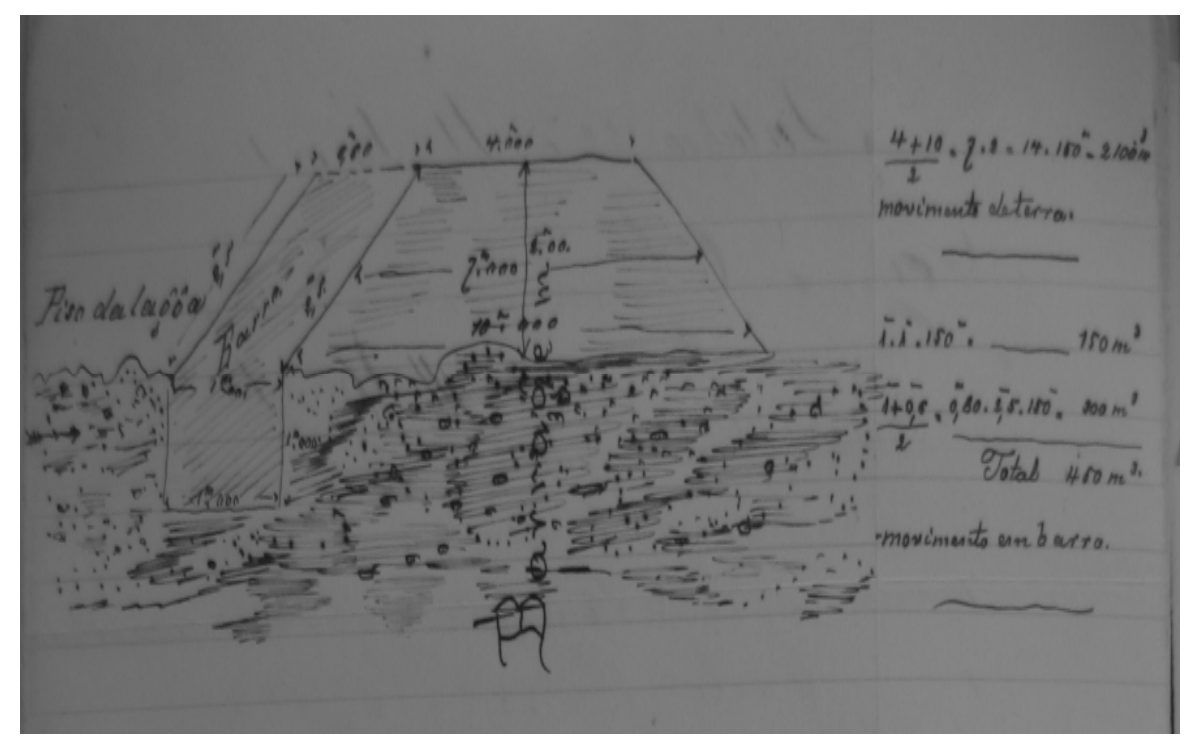

Fonte: APEC-Comissões de Socorros e Obras Públicas.

Segundo os signatários, esse projeto se baseava na experiência de outros países que, como a região Norte do Império, estavam sujeitos às secas periódicas. Diagnosticava-se, portanto como meio mais eficaz para minorar os efeitos das estiagens, a construção de vias-férreas, por meio da qual os habitantes do interior pudessem "receber os socorros de toda parte, ou como recurso extremo, buscar na emigração lenitivo aos seus padecimentos". " Para o GTDN "os efeitos calamitosos das secas têm suas causas profundas nestes dois aspectos: baixa produtividade da economia da região e incidência maior sobre a agricultura de subsistência". 5 No entanto, observa que "o excedente de população só se manifesta em toda sua crueza nos anos secos." 6

Os conselheiros consideravam o "Ceará de todas as províncias do Norte a que tem sido mais vexada pelas secas em diversas épocas, entende o

\footnotetext{
4 Ibid.

${ }^{5}$ GTDN - Uma Política de Desenvolvimento para o Norte. Revista Econômica do Nordeste, v. 28, n.4, p387-432, out./dez., 1997, p 421.

${ }^{6}$ Ibid., p 422.
} 
Ministério que por ela deve começar a tentativa que vai fazer". ${ }^{7} \mathrm{O}$ projeto Sinimbú propôs resgatar a parte já construída da via - férrea de Baturité, e a continuar com a possível celeridade o que restava por fazer; mas também iniciar outra via férrea que, seguindo do porto de Camocim passaria pela cidade de Granja e, contornasse a serra de Meruoca, terminando em Sobral, de onde mais tarde se prolongaria acompanhando a serra geral em direção ao Piauí.

Com a oficialização do projeto Pompeu Sinimbú surgiu a necessidade de se organizar não apenas Comissões de Socorros, como se dera nas secas anteriores, mas Comissões de Socorros e Obras Públicas. Para gerir um sistema de serviços e socorros se tornou crucial a formulação de um plano de gestão. Qualquer plano que fosse formulado teria que estar de acordo com as diretrizes do projeto Pompeu Sinimbú, ou seja, deveria se basear na utilização da mão de obra. Porém, só haveria mão de obra disponível se as famílias do sertão abandonassem os seus domicílios. Contudo, isso gerava uma verdadeira hecatombe social: mortalidade, mendicância, exploração sexual, aumento do número de órfãos e da violência. Por isso presidentes ${ }^{8}$ sem ligação com os liberais cearenses enviados a assumir o governo da província como João Aguiar e Henrique d'Ávila tentaram criar planos que evitassem o abandono dos domicílios.

O comendador João Aguiar, desconfiado devido às notícias que recebia de desvios de gêneros e dinheiros decidiu cancelar o envio de socorros ao interior. Ele procurou fazer os retirantes compreenderem "a necessidade de aproveitarem os recursos que ainda podiam ser-lhes proporcionados para

\footnotetext{
${ }^{7}$ Ibid.

${ }^{8}$ CARVALHO, José Murilo de. A Construção da ordem: a elite política imperial. Rio de Janeiro: Campos, 1980, p.36. Ele observa que a ocupação de cargos em diferentes províncias fazia parte da carreira.
} 
buscarem abrigo nesta capital ou em outro qualquer ponto, onde pudessem, com mais facilidade ser socorridos". ${ }^{9}$ Com isso, ele agravou mais ainda o problema, desencadeando um processo migratório em direção ao litoral e, sobretudo à capital cearense. ${ }^{10}$ De fato, o que provocava a deterioração social da população era a migração e não a falta d'água. Como observou o contraditório Rodolfo Teófilo “Quem possuía um depósito d’ água regular e podia preservá-lo do furto do peixe, atravessaria o flagelo sem passar por grandes privações”. ${ }^{11}$

Já o presidente Henrique d' Ávila adotou um plano oposto: tentou realizar o atendimento ao desvalido no próprio domicílio porque ele compreendia que o êxodo originava as aglomerações, "e estas as maiores desordens e males de toda espécie, tornando muito mais pesados os sacrifícios do Tesouro". ${ }^{12}$ Ele interrompeu completamente a saída de retirantes para fora da província, por que isso atraía sempre para a capital cearense um grande número de indigentes. Além, disso levou o socorro público a todas as comarcas da província, criando um comissariado geral em cada uma delas, e dividindo-as em tantos comissariados locais, quantas fossem as circunscrições de raio de circunferência de 4 a 5 léguas que existissem em cada uma delas.

Em todos esses pontos colocou armazéns de gêneros alimentícios ficando o armazém central a cargo do comissário geral e os locais dirigidos pelos comissários locais. Estabeleceu por mar e por terra meios de transporte de modo a assegurar mensalmente a remessa de gêneros necessários para todas as comarcas da província para satisfazerem as exigências dos socorros públicos.

\footnotetext{
${ }^{9}$ Relatório de 1878 , p. 10.

${ }^{10}$ THEÓPHILO, Rodolfo. História das Secas no Ceará (1878-1880). Rio de Janeiro: Imprensa Inglesa, 1922, p.128.

11 Ibid, p.81.

12 APEC - Relatório do presidente de província Henrique D’Ávila. Fortaleza: Tipografia Econômica, 1889, p53.
} 
Ávila autorizou os comissários gerais a fazerem o abatimento de gado vacum para fornecerem carne verde duas ou três vezes por semana aos desvalidos. E dessa forma, localizados nas terras que cultivavam os agricultores reduzidos a indigência pela completa ausência de cultura, recebiam alimento mensalmente nos armazéns de suas circunscrições, e faziam seus roçados com tempo para poderem efetuar maiores plantações na época própria, fornecendolhes a administração todas as sementes de que necessitarem e que forem requisitadas aos comissários gerais. Ao assumir a administração da província Henrique d'Ávila encontrou o serviço dos socorros públicos onerado com uma dívida passiva de perto de 3 mil contos de réis, grande parte já liquidada, e parte em liquidação.

Essa dívida e a despesa já realizada por conta das obras públicas desde janeiro até o fim de junho de 1889 elevaram-se a mais de 5 contos de réis. Na opinião de Ávila “não era possível manter esse serviço nessas condições de tão elevados sacrifícios do Tesouro Nacional porque, dentro de pouco tempo, toda a receita do Império não bastaria para satisfazer as exigências da seca do Ceará". ${ }^{13}$ Por outro lado, ele havia encontrado esse serviço inteiramente desorganizado e anarquizado, tendo "por objetivo principal fazer emigrar para fora da província o maior número de retirantes". ${ }^{14}$ Apesar do intenso processo de migração para fora do Ceará na seca de 1888-89 em direção às províncias do Norte e do Sul, como observou Maria Silvia Beozzo Bassanezi ${ }^{15}$, houve um esforço político durante o governo Caio Prado em controlar ou determinar a

\footnotetext{
13 APEC - Relatório do presidente de província Henrique D’Ávila. Fortaleza: Tipografia Econômica, 1889, p.4-5.

${ }^{14}$ Ibid., p.5.

${ }^{15}$ BASSANEZI, Maria Silvia Beozzo. Migrantes no Brasil da segunda metade do século XIX. Anais do XII Encontro da Associação Brasileira de Estudos Populacionais (ABEP), 23 a 27 de outubro de 2000, p.1-22.
} 
saída dos retirantes.

Porém, o presidente Henrique d'Ávila se viu forçado a pedir demissão do cargo de presidente da Província do Ceará pelo fato de não poder harmonizar os seus "planos de administração ao modo pelo qual o atual Ministério da Agricultura entende dirigir os assuntos relativos ao Ceará". ${ }^{16}$ No seu relatório não aparece o nome do seu sucessor porque não houve tempo dele ser escolhido em razão do governo do presidente Ávila ter durado aproximadamente um mês e meio. Apesar de constatar que a seca era o principal acontecimento da região e constituía uma preocupação geral, seu plano de assistência contrariava as elites cearenses e o próprio Ministério da Agricultura.

Ávila tentou suprimir os gastos com a burocracia e por isso descontentou as elites. De fato, como ressaltou José Murilo de Carvalho por causa de sua dependência financeira em relação ao emprego público, essas pessoas tinham um "interesse material muito concreto na manutenção e expansão da burocracia". 17 Desse modo, a combinação entre estatismo e reformismo era mais fácil para os magistrados nordestinos, sobretudo para os que eram provenientes "de províncias onde o problema da mão de obra escrava não era tão sério, como o Ceará”. ${ }^{18}$

Em 1889, depois de derrubada a monarquia Capanema escreveu ao rei reclamando, dizendo que "a luta inglória com uma administração vacilante que ora decidia isto, ora aquilo, tomava-se todo o tempo, e interrompia a cada

\footnotetext{
${ }^{16}$ APEC - Relatório do presidente de província Henrique D’Ávila. Fortaleza: Tipografia Econômica, 1889. .

${ }^{17}$ CARVALHO, José Murilo de. A Construção da Ordem: a elite política imperial. Teatro de Sombras: a política imperial. Rio de Janeiro: Civilização Brasileira, 2003, p.113.

${ }^{18}$ Ibid, p.222. Não se deve com isso considerar que foi pequena a população negra do Ceará, pois como observou Eurípede A. Funes essa presença se efetivou por meio dos seus descendentes como mulatos e cafuzos. Sobre isso vide: FUNES, Eurípedes A. Negros no Ceará. In: SOUSA, Simone. História do Ceará. Fortaleza: Edições Demócrito Rocha, 2000, p.102 a 132.
} 
passo qualquer trabalho que eu intentasse". ${ }^{19}$ Ele não poupou o rei de ouvir suas queixas, dizendo: "Eu procurei tornar-nos independente, dando a lavoura o meio fácil de livrar do seu maior flagelo". ${ }^{20}$ Essa foi enviada no mesmo ano da deposição do rei e da eclosão de mais uma seca no Ceará. As medidas propostas por Capanema foram as mais sensatas, tanto que Nogueira Acióli o herdeiro político do Senador Pompeu admitiu na seca de 1898 que era improfícua qualquer "sugestão para convencer a população pobre dos sertões que o meio mais eficaz de precaver-se contra tais infortúnios é prover-se com o excedente dos anos fartos, trabalhar duplamente nas vésperas da calamidade". ${ }^{21}$ Assim, como a violência a imprevidência dos sertanejos era vista pelo chefe da oligarquia como algo ingênito.

A principal diferença entre o projeto Capanema e o plano Gabaglia era que o primeiro intentava, através da educação agrícola e de medidas preventivas enfrentar o problema das estiagens. Já o segundo, apesar de também discordar da noção de que a seca era o motivo do atraso e da calamidade creditava a desorganização do comércio e a falta de fiscalização e controle por parte do governo. Na sessão do Instituto para discutir o plano Gabaglia em 1878 o barão de Capanema decidiu faltar, dizendo-se enfermo, mas mandou uma carta na qual declarava que:

a questão é ociosa, pois condições climatológicas que subsistiam na época terciária, atravessando todos os períodos geológicos até hoje, não é a débil mão do homem, que agora as poderá alterar. A questão é outra, de execução relativamente fácil e de resultados seguros. Já se sabe que cada geração do Ceará passa por duas secas, é uma calamidade periódica; como é impossível fazer chover a vontade,

\footnotetext{
${ }^{19}$ BNRJ: Documentos do Barão de Capanema. Maço 200, Doc 9111, p.2.

${ }^{20}$ BNRJ: Documentos do Barão de Capanema. Maço 200, Doc 9111, p.2.

${ }^{21}$ APEC - Mensagem apresentada pelo presidente do Estado Antonio pinto Nogueira Acioli à Assembléia Legislativa do Ceará. Fortaleza: Tipografia Econômica, 4 de julho de 1898, p.24.
} 
previnam-se os meios para arrostá-la placidamente. ${ }^{22}$

Diferente de Gabaglia para Capanema a seca era periódica e, portanto era preciso aprender a conviver com ela. Portanto, Gabaglia procurou demonstrar que "é menos claro do que parece o atribuir-se às secas da província o atraso geral dela". ${ }^{23}$ No entanto, ele observou que a violência era uma calamidade que provocava outra calamidade: a seca.

O calamitoso resultado atribuído às secas do Ceará e o estado relativamente atrasado da província, também imputado a mesma origem, resultam mais do complexo de muitas outras circunstâncias e motivos não discutidos, do que unicamente do fantasma - secas ou falta de chuvas. ${ }^{24}$

Para Gabaglia existiam 3 grande calamidade no Ceará: a violência, as secas e as enchentes. A violência atrapalhava o desenvolvimento da agricultura e, portanto agrava as secas. Já as enchentes se deviam ao represamento dos rios.

O plano Gabaglia tomava a escassez de chuvas como um problema menor que as inundações, pois para ele as enchentes eram piores que as secas. Além disso, ele era contrário à noção do senador Pompeu de que as secas eram cíclicas e, portanto ela não seria um problema permanente. Por isso, a parte principal do seu plano consistia em desobstruir rios represados e legislar sobre o funcionamento de açudes e represas. Para Gabaglia não havia falta de água, o que ocorria era uma má gestão dos recursos hídricos. Liberando os rios dos represamentos e limpando-se os seus leitos e margens se teria uma fluidez de águas que revigoraria a vegetação disponível aos rebanhos de gado. Por ele

\footnotetext{
${ }^{22}$ ALVES, Joaquim. História das Secas no Ceará (séculos XVIII-XIX). Ed. fac. símile. Fortaleza: Fundação Waldemar Alcântara, 2003, p. 198.

${ }^{23}$ GABAGLIA, Giácomo Raja. Ensaios sobre alguns melhoramentos tendentes à prosperidade da província do Ceará. Rio de Janeiro: Tipografia Nacional, 1877, p.114.

${ }^{24}$ Ibid., p.86.
} 
defendeu que se construíssem canais ao invés de fontes artesianas, poço ou açudes. Restabelecida a circulação pluvial caberia aos fazendeiros e agricultores precaveram-se para eventualidade das estações estéreis.

Também os criadores de gado e agricultores deveriam cultivar e preparar a terra, evitando invadir terra pública ou particular, zombando da lei e desprezando as queixas "daqueles que pela força ou com represálias não podem manter os seus direitos de propriedade". ${ }^{25}$ Deixava-se todo ano de plantar arvores que poderiam servir a alimentação do gado como carnaúbas, canafístulas, cardos, mamoeiros, juás, e muitas outras plantas “os gados comem as ramas com sofreguidão". ${ }^{26}$ Quanto à formação do feno ou a arrecadação do capim seco proposto por Capanema, Gabaglia mostra com ironia que estas são consideradas inexeqüíveis ou dispendiosas por exigem trabalho e desviam o povo da rotina. Por isso, sua proposta é de que fossem plantas árvores que os animais comeriam soltos na natureza.

A diferença entre o projeto Capanema e o projeto Gabaglia foi que este último se baseou na idéia de investimentos públicos e na construção de algumas obras públicas como portos e estradas. Apesar de reconhecer, a questão da violência, da imprevidência dos agricultores e criadores de gado seu projeto de desenvolvimento se baseou numa espécie de reforma tributária, no replantio de árvores e numa legislação que controlasse a condição hidráulica da província. O projeto Gabaglia era dependente de investimentos poderosos do estado, por esse motivo ele se tornou mais bem visto que o projeto Capanema e se aproximou do projeto político Pompeu Sinimbú. Mas, havia uma diferença importante entre os dois projetos. Para Pompeu era preciso utilizar a seca para

\footnotetext{
${ }^{25}$ Ibid., p 143.

${ }^{26}$ Ibid., p.144.
} 
realizar o desenvolvimento da província. Para Gabaglia a seca não a principal questão, pois se poderia com as medidas que ele indicou realizar o desenvolvimento econômico e com isto, a seca se tornaria imperceptível.

Para Gabaglia mais importante que a "questão da seca" era a questão financeira. "A questão financeira só terá interesse dado o caso de aceitar-se o plano proposto; contestado ele ou aceita outra idéia melhor, a continuação deste ensaio fora um simples castelo de cartas". ${ }^{27}$ Para Gabaglia se a situação financeira da província estivesse sanada seria possível pedir empréstimo ao governo para realizar a construção de canais, estradas e portos.

As sugestões apresentadas ao governo Imperial pelo Instituto Politécnico tiveram como origem as conclusões dos dois ensaios de Giácomo Raja Gabaglia, topógrafo da Comissão Científica de Exploração. Os cientistas do Império não adiantaram nenhuma sugestão nova, nenhuma experiência científica de relevo ao plano Gabaglia. Restringiram-se todos ao comentário da utilidade ou inutilidade dos açudes, da possibilidade ou impossibilidade do governo realizar as obras sugeridas, da conveniência ou inconveniência do governo se dirigir diretamente ao governo. ${ }^{28}$

Sobre as secas, Raja Gabaglia observou que era na província era axioma corrente que as chuvas eram escassas e isso era uma máxima imbuída no povo cearense. Disse ele com derrisão: "Falências por causa das secas, emigrações pelas secas, decadência e ruína geral pelas secas, secas para aqui e secas para acolá e tudo o mais que é possível imaginar. Consulte-se com calma o que há de provado, e se tudo é devido à causa exibida". ${ }^{29}$ Essa foi à diferença mais importante entre a Comissão Científica de Exploração e o grupo do

\footnotetext{
${ }_{28}^{27}$ Ibid., p.150.

${ }^{29}$ GABAGLIA, F. A. Raja. Ensaios sobre alguns melhoramentos Tendentes á Prosperidade do Ceará. Rio de Janeiro: Tipografia do Correio Mercantil, 1861, p.28.
} 
Senador Pompeu. Para os comissários as secas não eram a razão do atraso do progresso material na província, tanto era assim que, os seus trabalhos publicados tinham temas como o que nomeou Gabaglia um dos seus estudos: "Ensaios sobre alguns melhoramentos Tendentes á Prosperidade do Ceará". Mas, para as elites políticas e técnicas ligadas ao Partido Liberal do Ceará do Senador Pompeu, seca e atraso material eram um axioma: se há seca, logo há atraso material.

As elites do Norte precisavam atuar, para se manterem no poder, tanto nas disputas locais entre liberais e conservadores, quanto nos embates nacionais com as elites do Norte e as do Sul em torno do aporte de melhoramentos materiais porque as elites políticas eram também econômicas ou representavam os seus interesses. A diferença era que as elites do Sul tinham o café, os escravos e o mate como mercadorias ou atividades econômicas que despertavam o interesse financeiro da iniciativa privada. $\mathrm{O}$ surto algodoeiro que se verificou no Ceará durante a guerra de Secessão (1861 a 1865) foi um episódio que indicou duas coisas: a província precisava se modernizar para competir, e segundo, a seca era decorrente do atraso econômico e não o atraso econômico decorrente da seca.

No entanto, as elites do Norte, especialmente as do Ceará, condicionaram o progresso econômico da região ao combate às secas. Para equilibrar essas diferenças materiais a seca era o caminho a ser escolhido, por isso ao se referir às estiagens de 1792 e 1825, quando o povo desanimado, emigrou em direção às praias e às cidades, principalmente à capital, concorreu para o aumento dos preços e, por conseguinte do estado de miséria. Lamentou, no entanto, que a "imprudência do governo foi de não aproveitar o serviço: 
cometeu o grande erro de preferir dar ao povo esmola, em vez de serviço e salário". Com isso, a idéia de aproveitar a mão de obra abundante já estava colocada antes mesmo da seca de 1877-79. Lamentou Pompeu que o presidente da província fosse um homem de espírito acanhado, porque "consentiu na aglomeração de dezenas de imigrantes, que durante muitos meses viveram da distribuição diária de farinha, etc". ${ }^{30}$

Nas secas anteriores a 1877 houve migração e socorros públicos, porém seguiu-se a proposta do senador Pompeu que propôs que se utilizassem esses momentos e a mão de obra disponível para a realização de obras públicas. Ele fez isso no mesmo discurso em que criticou as diferenças materiais entre o Norte e o Sul. Entretanto, a disposição não apenas do senador Pompeu, mas também da sua família em se envolver com a execução de obras públicas esbarraria na promulgação da Nova Lei Eleitoral de $1876^{31}$, pois esta preconizou maior regulação na realização de obras públicas, impedindo que ocupantes dos cargos públicos se beneficiassem dos contratos de arrematação.

Essa lei provocou dúvidas entre políticos cearenses aliados do senador Pompeu e este para dirimi-las escreveu ao advogado e deputado cearense Leandro Ratisbona (o Ratis), que avaliou o artigo terceiro, nos seus parágrafos 3 e 4 da Nova Lei Eleitoral ao tratarem da questão, não compreendiam que o princípio das incompatibilidades "foi estabelecido unicamente para os funcionários públicos de certa categoria". ${ }^{32}$ De fato, a lei não fazia restrição determinando que não poderiam ser votados para membros das assembléias provinciais, deputados e senadores, contratadores, arrematantes

\footnotetext{
${ }^{30}$ Ibid.

${ }^{31}$ FERREIRA, Manoel Rodrigues. A Evolução do Sistema Eleitoral Brasileiro. Brasília: Senado Federal, Secretaria Especial de Editoração e publicação, 2001.

${ }^{32}$ CAMARA, José Aurélio Saraiva (org.). Op. cit., p 15.
} 
ou interessados na arrematação de rendimentos, obras ou fornecimentos públicos "naquela província em que os respectivos contratos e arrematação tenham execuções e durante o tempo deles". ${ }^{33}$ Com isso, a lei proibia que as pessoas que tivessem contratos com o governo não poderiam ocupar cargos eletivos. O contrário também valia, quem estivesse ocupando funções públicas não poderia concorrer aos contratos das obras públicas.

Esse dispositivo das incompatibilidades ao separar a iniciativa particular do poder público era um óbice aos interesses do senador Pompeu e dos seus parentes, que não poderiam receber a concessão para explorar a estrada de ferro de Baturité. Leandro Ratisbona, eleito deputado geral pelo Ceará em 1864, era conhecido como um jurisconsulto e orador contumaz, um exemplo clássico do advogado verborrágico, afeito a distorcer a lei em benefícios dos seus aliados.

Embora a lei fosse clara, ele considerava o princípio da incompatibilidade um equívoco por ser favorável, é claro, ao seu amigo Pompeu. De acordo com ele, não tinha importância o fato de que dos trabalhos e obras públicas, embora devessem ser confiados em regra à iniciativa particular, fossem entregues a administração pública porque isso era apenas uma questão de conveniência e não alterava o princípio da incompatibilidade, porque era sempre da autoridade pública que tudo emanava.

Era como se não houvesse para o deputado cearense diferença entre público e privado, ou melhor, era como se não houvesse privado, pois tudo emanava do estado. Dessa maneira não havia, no seu entender, meio algum de se ocultar a ação e influência do governo na execução de obras. Com isso, para ele não tinha importância se o empresário, o contratador dos trabalhos e obras 
públicas fosse um simples concessionário, sem favores de outra ordem, e se uma vez eleito deputado pudesse pretender muito mais do que já havia obtido? Embora tenha sido esse "o grande inconveniente que a lei quis evitar, ele era impossível em qualquer hipótese". ${ }^{34}$ No entanto, a concepção de que tudo emana do estado se consolidou com a execução do projeto Pompeu Sinimbú.

Apesar da Nova Lei Eleitoral a família Pompeu conseguiu a concessão para explorar a estrada de ferro de Baturité. Essa estrada teve início em 1876 e o próximo passo seria viabilizar economicamente o seu prolongamento. Mas, isso não ocorreu, pois se priorizou as estradas da Bahia e do Recife. Sinimbú aconselhou Pompeu a ter paciência, pois o governo imperial não estava em condições de dar as garantias necessárias aos empreendedores. $\mathrm{O}$ apoio de Sinimbú ao senador Pompeu decorria de aliança antiga entre esses liberais. Em 1859, quando pela primeira vez esteve no Conselho da Coroa, Sinimbú lamentou que na pasta que ocupava não pudesse concorrer para melhorar a situação do Ceará. Essa imbricação entre interesse público e particular se acentuou, a despeito da nova lei eleitoral, a partir de 1877.

Porém, quando governou a província em 1836 o padre Martiniano de Alencar se destacou pela sua acurada visão administrativa. Ele logo após a emancipação colonial, de maneira dúbia e vacilante fez as primeiras tentativas "procurando despertar a iniciativa particular por meio de prêmios e favores". ${ }^{35}$ A construção de açudes foi estimulada pela lei 414 que incentivava a realização dessas obras; "mas foi tão diminuto o prêmio que ela ofereceu que nenhum efeito tem causado". ${ }^{36}$ Por causa disso, ele duplicou a quantia destinada naquela

\footnotetext{
${ }^{34}$ Ibid, p. 122.

35 SOBRINHO, Tomás Pompeu. Açude Quixeramobim. Revista do Instituto do Ceará. Ano XVI, 1912, p.224.

${ }^{36}$ Ibid.
} 
lei para o prêmio de cada braça de açude (10\$000 por braça de extensão nos açudes de pedra e cal, e $5 \$ 000$ nos de terra) que se fizer; e, além disso, persuadiu as câmaras por suas posturas a obrigarem os proprietários ricos a construírem em suas fazendas estes reservatórios. ${ }^{37}$

Num oficio do engenheiro da província Adolfo Herbster ao presidente Joaquim Mendes da Cruz Guimarães em 1856, ele conta que o governo da província obrigou-se a mandar fazer o calçamento, daquela travessa, fornecendo um negociante desta Praça, proprietário de algumas casas no local onde a obra seria feita toda a pedra necessária para a obra. Desejou o engenheiro que aquela "prova de patriotismo" fosse contagiosa, o que pelo menos, cada proprietário concorresse com o seu contingente, para ajudar aos cofres provinciais na continuação de tão útil melhoramento. ${ }^{38}$ Havia o que se poderia chamar de uma interação entre o poder público e a iniciativa particular.

O desejo do engenheiro Herbster de maior envolvimento dos proprietários denota uma perspectiva de estado e sociedade marcada pelo liberalismo econômico. Assim, várias obras contavam o envolvimento do capital privado. Entre as obras ele julgou a abertura da Barra do Aracati a obra de maior urgência, e interesse para a Província, e particularmente para o comércio da importante praça do Aracati, onde conversou com alguns negociantes daquela cidade. Mostrou a eles a imensa vantagem daquela obra, e estes se dispuseram a promover uma subscrição entre os comerciantes daquela Praça para ajudarem os cofres provinciais na execução de tão grande melhoramento. ${ }^{39}$

Para o barão de Capanema era

\footnotetext{
${ }^{37}$ GIRÃO, Raimundo. História Econômica do Ceará. Monografia n. ${ }^{\circ}$ 2, Fortaleza: Editora Instituto do Ceará, 1947, p.29.

${ }^{38}$ TEÓFILO, Rodolfo, op. cit., p 26.

${ }^{39}$ Ibid, p.16.
} 
indispensável animar a iniciativa do povo; que lhe mostrem com fatos o resultado que ele deve atingir; aquilo que ele vê, o convence: o que só dificilmente se conseguirá com instruções, receitas, etc. Não se deve habituá-lo a esperar tudo do governo; este tem por dever cuidar de outros melhoramentos, como seja promover a arborização, lembrando-se, porém que isso depende de ensaios para afirmar para firmar um procedimento eficaz; uns lugares se prestam mais que outros, torna-se necessário adaptar processos às diversas condições locais, em relação a posição, terreno e clima. ${ }^{40}$

Contudo, a proposta de Pompeu de aproveitar a mão-de-obra migrante para a construção de estradas de ferro, baseava o desenvolvimento material da província não no incentivo à iniciativa particular, mas na ação direta do estado como agente do desenvolvimento econômico. No entanto, esse projeto apresentava uma contradição ou um efeito colateral que precisava ser resolvido, qual seja: como aproveitar a mão de obra, disponível nos anos de secas, através da emigração sem permitir que os emigrantes se aglomerassem desencadeando moléstias que acabavam virando epidemias e atingiam não apenas os pobres, mas ameaçavam as próprias elites? Para respondermos a essa questão teremos que esperar até a seca de 1877-79 para vermos como as elites dirigentes resolveram esse problema. O plano já estava pronto na cabeça do senador Pompeu e dos seus aliados, faltavam, porém duas coisas: acontecer uma seca e os liberais ascenderem ao poder na província e no Império.

Apesar de Pompeu duvidar da ascensão dos liberais ao Conselho da Coroa, escreveu ao visconde de Sinimbú, que no caso de uma mudança política torno a lembrar-lhe as instruções que deixei em suas mãos, pedindolhe que não admita a mínima modificação. Lembro mais os nomes do Dr. Antonio Sabino do Monte para chefe de polícia, e o do Dr.

\footnotetext{
${ }^{40}$ CAPANEMA, Barão de. Apontamentos sobre as secas do Ceará, Rio de Janeiro: Tipografia Nacional, 1878 p.18.
} 
Augusto Pinto Alves Pequeno para secretário da presidência desta província. São dois moços inteligentes e honestos em quem deposito inteira confiança. $^{41}$

Além de indicações políticas, entre as instruções estava certamente o modo como o ministro deveria proceder diante da seca.

Podemos dizer que o senador Pompeu com base na sua teoria de que as secas eram cíclicas anteviu que a seca que se avizinhava em 1877 poderia ser uma grande seca. Para termos idéia disso vamos avaliar a correspondência entre o seu genro Nogueira Acióli que estava na linha de sucessão da chefia política da família do senador Pompeu. Em carta ao senador de 22 de fevereiro de 1877, Acióli relatou suas impressões sobre a seca, afirmando-lhe que em todo o Cariri o inverno ia muito bem e chovia até no ab, o que o levava a acreditar que não haveria seca. Mas, se houvesse ele seguiria os "judiciosos conselhos" do senador, ${ }^{42}$ que temendo um quadro de estio, onde se faria como já se fez escassear os alimentos no comércio, desencadeando uma crise de abastecimento, recomendou ao seu genro que tomasse medidas de natureza financeira como a compra e o estoque de gêneros de primeira necessidade.

A seca precisava ser declarada pelo governo, porém em muitas localidades como no Crato e vizinhança estava bem chovido. Porém como observou Nogueira Acióli, isto de nada serviria se "não chovesse em outros pontos, porque a [população] desvalida emigrará para aí e a miséria aparecerá. Em Baturité, Aracati e Maranguape já existem muitos retirantes”. ${ }^{43}$ Com isso, se as chuvas não ocorressem de modo uniforme em todos os municípios a população daqueles onde não chovesse migraria para os locais com chuvas. Esse

${ }^{41}$ CAMARA, José Aurélio Saraiva (org.). Carta de Pompeu ao Visconde de Sinimbú. Fortaleza, 7 de agosto de 1877. Correspondência do Senador Pompeu. Fortaleza: Tipografia Minerva, 1960, p.114.

${ }^{42}$ Ibid., p. 202.

${ }^{43}$ Ibid., p. 210. 
movimento era comum em tempos de seca e poderíamos dizer que se dava de modo costumeiro. Semanas depois, em mais de uma carta Acióli relata ao sogro enfermo que se estava em plena seca. As notícias que chegavam do sertão eram desanimadoras, a fome ia aparecendo em diversos pontos da província, e indivíduos perversos se aproveitavam dela para cometerem crimes. A falta de segurança era geral e em Quixeramobim e em Limoeiro, havia bandos armados que atacavam pelas estradas para roubarem.

No entanto, a declaração da seca não significava ausência absoluta de chuvas, pois, considerando-se a definição técnico-científica de Caio Lóssio Botelho, o fenômeno da seca não era decorrente da falta d'água, mas da má distribuição das chuvas no tempo e no espaço. Com isso, a seca tal qual nós a conhecemos, foi um fenômeno tipicamente brasileiro. Observou Botelho que a República Federal da Alemanha apesar de ter uma média pluviométrica de 690 milímetros, não apresentava a fenomenologia da seca. ${ }^{44}$ De fato, pois como observou Tomas Pompeu Sobrinho a seca dependia também do esforço ou da capacidade políticas das elites. Essa má distribuição das chuvas levava a que em alguns pontos do Ceará chovesse em demasia, provocando alagamentos em pleno período de seca. Entretanto, o projeto Pompeu Sinimbú desencadeava o abandono generalizado dos domicílios, mesmo onde havia chuvas.

Com o passar dos meses e a ausência de chuvas a migração aumentou, intensificando a movimentação das populações para várias cidades e vilas, mas principalmente para Fortaleza. Contudo, Acióli desinformado acerca das manipulações do senador Pompeu entendia que ainda não era tempo dos sertanejos estarem migrando porque ainda se podia socorrê-lo nos diversos

\footnotetext{
${ }^{44}$ BOTELHO, Caio Lóssio. O secular problema da seca. Revista do Instituto do Ceará - Ano CV -1991, p.98.
} 
pontos da província. Mas como eles receavam no futuro não poderem mais emigrar, e temendo o agravamento da situação, procurava se deslocarem o quanto antes. Entretanto, em sua opinião, embora o presidente Estelita tivesse tomado todas as medidas necessárias para minorar os efeitos da seca, acreditava que ele tinha se excedido na distribuição dos socorros, pois era cedo para mandar gêneros ao sertão, que não durariam até o mês de novembro, quando a seca teria chegado ao seu auge, e neste tempo, o governo já tendo gastado os recursos não poderia prestar o socorro aos desvalidos, o que agravaria a calamidade.

Se de um lado Caetano Estelita dilapidava os parcos recursos da Tesouraria Provincial com socorros, de outro o senador Pompeu, no dia 2 de abril, começou a organizar a bancada cearense no Senado e na Câmara. Ele enviou uma carta ao deputado Tristão de Alencar Araripe lembrando a este a idéia de se fazer uma reunião dos senadores e deputados cearenses para tratar das circunstâncias em que se achava a província do Ceará em relação à seca que começava a "declarar-se". O termo empregado era exatamente este, pois a seca era uma decorrência não apenas da falta de chuva, mas também do esforço político para efetivá-la, para declará-la e isso demandava articulação política.

Diante da anuência dos deputados da câmara, Araripe marcou a reunião para o dia 6 abril, numa das salas das comissões. Como o senador Pompeu não pode comparecer a reunião foi prorrogada para outro dia. $\mathrm{O}$ ministro do Império pronunciou no dia 14 de abril um discurso favorável à assistência aos desvalidos da seca, no caso da seca piorar. Ademais selou em reunião fechada um acordo com a representação cearense. Com isso, a bancada achou aconselhável, naquele momento, não representar ostensivamente sobre o 
estado da seca na província, porém, se caso ela se agravasse eles procurariam estabelecer novo acordo.

Entretanto, Pompeu parece haver deixado Nogueira Acióli, seu sucessor no comando da família, de fora das articulações políticas. Por isso ele não entendia os gastos prematuros do presidente, observando que "se o governo, no entanto, estivesse disposto a grandes gastos, o que duvidava nada se perderia com as medidas já tomadas pelo presidente". " Vê-se que Acióli não estava informado acerca dos acordos acertados no gabinete do ministro, pois ele ainda não assumira o controle da família e Pompeu era embora doente, o capitão do barco e o conduzia com firmeza. Para se ter uma noção do peso da chefia familiar, Nogueira Acióli para construir um muro no sítio Orilândia onde o clã morava, não tomou a iniciativa sem consultar o senador. Como se constatou depois, os gastos prematuros de Estelita foram compensados com o envio de largos recursos destinados em 1877, mas, sobretudo em 1878 por conta da verba destinada aos socorros públicos. O presidente Estelita era um aliado do senador que de tão influente e poderoso recomendava a ele algumas medidas de natureza administrativas, cobrando-o que restabelecesse as finanças públicas da província.

O presidente da Província Caetano Estelita como parte das medidas de socorros públicos abriu um crédito de 35 contos de réis, remetendo parte desta quantia ás comissões nomeadas, recomendando-lhes que socorressem os desvalidos, não com a esmola, mas dando-lhes trabalho e salário. Em troca os trabalhadores foram empregados em obras como os reparos nos edifícios públicos, a construção de cadeias, escolas e açudes. ${ }^{46} \mathrm{O}$ modo adotado de

\footnotetext{
${ }^{45}$ CAMARA, José Aurélio Saraiva (org.). Op. cit., p.214-215.

${ }^{46}$ TEÓFILO, Rodolfo. A História das Secas no Ceará. Rio de Janeiro: Imprensa Inglesa, 1922,
} 
socorrer os desvalidos logo que foi declarada a seca em 1877, baseou-se na exploração da mão de obra do trabalhador sertanejo como defendia o senador Pompeu.

O juiz interino de direito de São João do Príncipe, José André dos Santos, no final de 1877 , quando a seca já se encaminhava para o seu primeiro ano, compreendeu o sentido da política de socorros públicos empregada até aquele momento. Ele avaliou como acertado as medidas tomadas de mandar aplicar dinheiros em obras de utilidade pública nos lugares onde o povo flagelado pela seca implorava "com o louvável fim de duplicar dois bens: o sustento a mísera pobreza e o progresso material das localidades em cujo empenho faz evitar a emigração desta província que em seu auge promete despovoá-la”. ${ }^{47}$ O juiz solicitou ao presidente Caetano Estelita a remessa de recursos para terminar a igreja da povoação de Marrecas e construir um cemitério. Essa povoação foi edificada com recursos de particulares que abriram duas estradas e construíram casas largas e asseadas, mas agora era impulsionada com os recursos públicos.

As notícias que chegavam em 1877 ao Rio de Janeiro, sede da Corte, eram alarmantes. Os cearenses ilustres que lá residiam, temendo seus efeitos, intercederam junto ao governo pedindo providências para que se garantissem socorros a aproximadamente 500 mil indivíduos. O governo imperial assentiu com os recursos necessários as despesas com o atendimento daquele número de vítimas. Enquanto isso, vários deputados acorreram a D. Pedro II, recém chegado do exterior que se mostrou impressionado com o flagelo, a ponto de alguns lhe atribuírem à frase pomposa segundo a qual ele teria posto a venda os 
últimos brilhantes da coroa, contanto que nenhum cearense morresse de fome. A despeito da autoria desta frase, o fato é que a seca ganhou contornos imperiais com a assinatura de um decreto pelo Ministro da Fazenda, Barão de Cotegipe, de um crédito de 2 mil contos para o socorro às províncias devastadas. Esse dinheiro distribuído entre as províncias amainou os efeitos da seca ao longo de 1877.

Contudo, essas medidas não eram tomadas sem oposição, como a que se deu na sessão de 17 de abril de 1877, quando José de Alencar se pronunciou acerca das notícias que circulavam na capital do Império a respeito da seca no Norte. Leu em uma das mais importantes folhas da Corte o extrato de uma carta em que se anunciava uma seca no Ceará, sua província natal, tão grave que fazia recear uma calamidade semelhante às de 1825 ou 1845. Segundo Alencar havia incontestavelmente exageração, pois quem conhecia a província do Ceará e o interior das províncias do Norte sabe que até o mês de maio ou meados do mês de junho não se deve desistir de esperar o inverno. Por conseguinte, não se devia, ao seu modo de ver, anunciar uma seca tal quais as anteriores. José de Alencar, diferente do seu pai, era ligado ao partido conservador e no Ceará sofria a oposição dos liberais chefiados pelo senador Pompeu, tratou de amenizar os discursos que ele considerava exagerado em torno da estiagem. Por isso, afirmou da tribuna que entendia haver na insistência com que se exageravam as notícias da seca um "pouco de espírito de oposição". 48

Esse espírito de oposição no ano seguinte se tornou situação com a ascensão do ministro Sinimbú a presidência do Conselho de Estado, mas,

\footnotetext{
${ }^{48}$ TEÓFILO, Rodolfo. A História das Secas no Ceará. Rio de Janeiro: Imprensa Inglesa, 1922, p.86.
} 
sobretudo devido a sua profunda amizade e companheirismo com o senador Tomás Pompeu. Os dois senadores atuavam na Corte, de longa data, a favor da formação de um ministério liberal. A correspondência conhecida do político cearense era, na maior parte, composta por cartas do visconde. Os dois se tratavam de modo afetuoso, a ponto de Sinimbú lamentar a saída daquele do Rio de Janeiro ao Ceará em 1877. Dentre os vários assuntos conversados a seca era um dos principais, e por isso não deixava de ser lembrado em frases que indagavam sobre a seca e terminavam as cartas sempre de modo amigável e afetuoso.

Quando teve início o ano de 1878, novos pedidos foram feitos e dessa vez o Ceará contou com o apoio do ministro da agricultura viação e obras - João Lins Vieira Cansação de Sinimbú, ou apenas Sinimbú, em favor das elites cearenses. Como anotou Oliveira Lima, Sinimbú era um político de eloquiência um pouco antiquada, mas de planos ousados, como veremos adiante. ${ }^{49}$ Dessa articulação decorreu o modelo de atendimento aos retirantes desvalidos, pois com a mediação de tão ilustre e prestigiosa figura do Império brasileiro frente a um rei influenciável, D. Pedro II, não foi difícil aprovar um crédito volumoso para atender as elites locais nos seus anseios assistencialistas.

Após o fim da gestão Estelita assumiu o cargo de presidente da província José Júlio de Albuquerque Barros que tinha a confiança ilimitada do Gabinete Liberal e com especialidade do presidente do Conselho, o Sr. Sinimbú. Os serviços que prestou na administração do Ceará, permanecendo no cargo até o final da seca, lhe aumentaram tanto o amor próprio, que não este não deixava de ser um pouco exagerado, a ponto de não admitir que ninguém censurasse os

\footnotetext{
${ }^{49}$ VAINFAS, Ronaldo (org.). Dicionário do Brasil Imperial (1822- 1889). Rio de Janeiro: Objetiva, 2002, p.405.
} 
seus atos, quanto mais os fiscalizasse. ${ }^{50} \mathrm{~A}$ opção pelo assistencialismo encampado pelas elites cearenses ligadas ao partido liberal do Senador Pompeu e do seu dileto genro Nogueira Acióli se assentou no projeto Sinimbú. Este que tinha como princípio aproveitar, o termo é esse, a mão de obra do trabalhador desvalido para a realização do progresso material da província.

Ao chegar ao Ceará e com problemas sérios de saúde, Pompeu respondeu a carta do visconde já temendo a invalidez provocada pela doença ou mesmo o falecimento. Escreveu ao amigo que se caso agravassem-se seus padecimentos e ele ficasse impossibilitado de se comunicar diretamente com ele, que este poderia se dirigir sobre negócios políticos seu genro, o Dr. Antonio Pinto Nogueira Acióli que "era a influencia política mais poderosa do sul da província por sua numerosa família" ${ }^{51}$. Como observou Linda Lewin referindose a Paraíba, para os políticos da oligarquia estadual fazer parte de uma parentela ou de uma família extensa constituía a "mais importante afiliação organizacional". 52

Além do seu genro Nogueira Acióli, que depois veio a constituir uma poderosa oligarquia, o senador indicou seu filho Tomás Pompeu de Souza Brasil, que há alguns anos estava à frente do jornal Cearense, órgão ligado ao partido liberal. Ambos eram membros do diretório central, único que a imprensa da província podia que vinham do centro sobre a seca continuavam a ser más, apesar da chuvarada dos últimos dias. Pompeu fez a transição da sua influência política ao seu genro e filho, de modo que após sua morte em 2 de setembro de 1877, Sinimbú enviou uma carta no dia $1^{\circ}$ de outubro ao Tomás Pompeu, na qual lamentava a morte do senador. Dizia que nele Pompeu acharia sempre

\footnotetext{
${ }^{50}$ TEÓFILO, Rodolfo. Op. cit, p. 281.

${ }^{51}$ CAMARA, José Aurélio Saraiva (org.). Op. cit, p. 115.

${ }^{52}$ LEWIN, Linda. Política e Parentela na Paraíba. Rio de Janeiro: Record, 1993, p.113.
} 
estima e amizade que lhe deviam "merecer os filhos daqueles de quem sempre fui amigo sincero e dedicado. Mande-me suas ordens, e creia que sou" ${ }^{53}$.

Entretanto, Tomás Pompeu, o filho, não teve a mesma projeção do pai que conjugou com maestria o exercício da política com o da ciência. O senador, além da liderança mais influente do Ceará na segunda metade do século XIX, foi autor de obras importantes sobre a província, mormente relativas à população e estatística e em mais de uma delas abordou a questão das secas. O que é mais importante na biografia de Pompeu é que ele entrelaçou sua carreira de cientista com a de político. Era um homem de grande cultura e ciência sendo que de acordo com Manoel Fernandes a obra "Ensaio Estatístico" tinha inspiração humboldiana. ${ }^{54}$

Ele ter morrido sem completar suas memórias a cerca da seca de 1877 foi uma pena. O Tomás Pompeu filho procurou seguir os passos do pai por quem tinha veneração, mas não logrou o mesmo sucesso confirmando a assertiva de Max Weber ${ }^{55}$ que antepunha o sábio ao político. Para o sociólogo alemão, a ciência e a política eram duas vocações profundamente divergentes. Tomás Pompeu logo descobrira isso, não fosse à ajuda do irmão e do cunhado, Nogueira Acióli, teria sofrido por demais as consequiências do seu gênio de homem de ciência.

Embora tenha sido eleito deputado provincial, perdeu três eleições que o levaram a se desinteressar pela carreira política. Cansou-se de ter que percorrer o sertão indo de casa em casa fazendo visitas e pedindo votos. Além, é claro, dos banquetes que se era quase obrigado a oferecer, seguindo-se de

\footnotetext{
${ }^{53}$ CAMARA, José Aurélio Saraiva. (org.). Op. cit, p.

${ }^{54}$ NETO SOUSA, Manoel Fernandes de. Senador Pompeu: um geógrafo do Império Brasil. São Paulo: Dissertação de Mestrado, USP, 1997.

${ }_{55}$ WEBER, Max. Le Savant e le Politique. (Col. 10/18), Union Generale des Éditions, Paris, 1971, p.181.
} 
discursos aos comensais. Gastava-se muito para fazer-se um político eleito. Tomás Pompeu despendeu em eleições 63 contos de réis, a tal ponto que em 1889 não quis concorrer a cargos, terminando por ir trabalhar na fábrica de fiação e tecidos fundada por seu irmão e o cunhado, Nogueira Acioli, que assumiu o comando da família, constituindo a mais poderosa oligarquia que já governou o Ceará. Com isso, o senador Pompeu conseguiu garantir mesmo depois de morto que a chefia da família fosse entregue ao genro e segundo e igualmente importante que durante as secas os socorros públicos fossem prestados, aproveitando-se a mão de obra desvalida para a construção de diversas obras públicas.

O senador Pompeu conseguiu repassar o comando político da província para a sua família, que se tornou uma poderosa oligarquia, a sua proposta de utilizar as secas para a realização de obras públicas com o objetivo de desenvolver o progresso material do Ceará e seu nome se tornou sobrenome por várias gerações. Por isso, ele é o que denominamos de um político pósmortem.

Também os criadores de gado e agricultores deveriam cultivar e preparar a terra, evitando invadir terra pública ou particular, zombando da lei e desprezando as queixas "daqueles que pela força ou com represálias não podem manter os seus direitos de propriedade". ${ }^{56}$ Deixava-se todo ano de plantar arvores que poderiam servir a alimentação do gado como carnaúbas, cafístulas, cardos, mamoeiros, juás, e muitas outras plantas "os gados comem as ramas com sofreguidão. ${ }^{57}$ Quanto a formação do feno ou a arrecadação do capim seco proposto por Capanema, Gabaglia mostra com ironia que estas são consideradas

\footnotetext{
${ }^{56}$ GABAGLIA, Giácomo Raja. Ensaios sobre alguns melhoramentos tendentes à prosperidade da província do Ceará. Rio de Janeiro: Tipografia Nacional, 1877, p 143.

${ }^{57}$ Ibid., p. 144.
} 
inexeqüíveis ou dispendiosas por exigem trabalho e desviam o povo da rotina. Por isso, sua proposta é de que fossem plantas árvores que os animais comeriam soltos na natureza.

O projeto Pompeu Sinimbú embora pudesse ser aplicado à província do Norte, e mesmo que suas diretrizes tenham sido expostas pelo ministro Sinimbú em 1878 ao rei D. Pedro II, como voltadas para as secas no Norte, o fato é que a seca como um acontecimento político de 1877 a 1900 foi sempre um esforço das elites políticas cearenses. Se no Ceará a seca a partir de 1877 passou a sobrepujar os demais acontecimentos o mesmo não podemos dizer a respeito do Rio Grande do Norte, da Paraíba, de Pernambuco, do Piauí e da Bahia. Embora, as secas nas províncias do Rio Grande do Norte, da Paraíba e de Pernambuco fossem alvas de registros por meio de cronistas e estudos e observações técnicas elas não tinham uma elite vacilante quanto à possibilidade de evidenciar politicamente a seca.

IMAGEM 3: Açude do Cedro - barragem principal

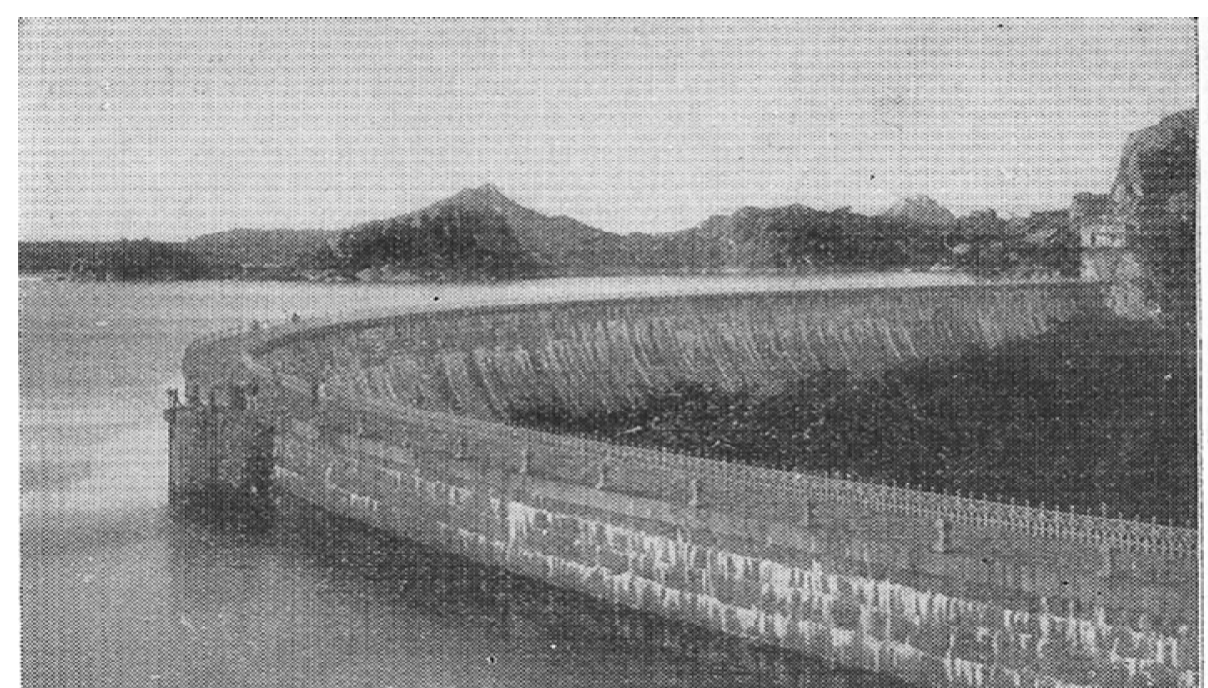

Fonte: SOUSA, José Bonifácio de Sousa. Quixadá: de fazenda a cidade. IBGE, Conselho Nacional de Estatística, 1960, p.35.

Giácomo Raja Gabaglia era contrário ao combate às secas por meio 
da construção de açudes. Ele defendeu que a seca se agravava devido ao represamento dos rios. Contudo, a despeito das suas opiniões técnicas a proposta vitoriosa foi a do senador Pompeu que preconizava a seca como óbice e da construção de grandes obras públicas. No Ceará um exemplo disso foi a construção dos açudes Cedro e Choró.

Já na seca de 1888-89 a existência da estrada de ferro de Baturité possibilitou ao governo gerenciar os socorros públicos, distribuindo os trabalhadores em obras ao longo da estrada, evitando com isso as aglomerações. O governo por meio da estrada de ferro resolveu outro problema presente na seca de 1877-79 que era a dificuldade em fazer os retirantes abandonarem a capital cearense e depois fazê-los retornarem aos seus domicílios. Essa política implementada de Combate às secas se concentrou no Ceará com a realização de obras como açudes e estradas de ferro, porém observando-se as demais províncias podemos ver que elas também foram praticamente atingidas pelas mesmas secas.

TABELA 8

AS SECAS QUE ATINGIRAM ALGUMAS PROVÍNCIAS DO

\begin{tabular}{|c|c|c|c|}
\hline Ceará & R. G. do Norte & Paraíba & Pernambuco \\
\hline 1804 & 1808 & & \\
\hline 1810 & 1814 & & $1819-1820$ \\
\hline $1824-1825$ & $\begin{array}{l}1825 \\
1833\end{array}$ & $1824-1825$ & $\begin{array}{l}1824-1825 \\
1833-1835\end{array}$ \\
\hline 1844-1845 & 1845 & $1845-1846$ & $1845-1846$ \\
\hline $1877-1879$ & $1877-1879$ & $1877-1879$ & $1877-1879$ \\
\hline $1888-1889$ & $1888-1889$ & $1888-89$ & $1888-1889$ \\
\hline 1898 & 1898 & 1898 & 1898 \\
\hline 1900 & 1900 & & 1900 \\
\hline
\end{tabular}

Nesse sentido, o cronista Luiz Alípio Pereira da Silva observou que as demais províncias do Norte atingidas pela crise climática ficaram abandonadas, sem o apoio do governo geral, pois, durante toda a discussão 
política e técnica surgida em 1877, “o Ceará foi a única Província focalizada, como se fosse a única a sofrer a calamidade. Os representantes das demais províncias silenciaram, como se temessem atrair para eles a censura política dos dominantes ou desejassem negar a existência do flagelo". 58

De fato, as elites políticas cearenses assumiram desde a "grande seca" um papel individualista em relação às demais províncias do Norte. No entanto, foi crescendo entre elas um espírito de competição pelas benesses do estado, e nessa disputa, o Ceará saiu sempre vencedor por ter sido a província que inventou politicamente as secas. Ricardo Ismael chamou de a "força da diferença" as dificuldades das elites nordestinas de cooperaram entre si nos momentos de reivindicarem benefícios políticos para a região. Ele faz essa conclusão observando o debate acerca da Constituição de 1988.

Essa vantagem do Ceará em relação às demais províncias do Norte se consolidou na medida em que o projeto Pompeu Sinimbú foi sendo aprimorado. Na seca de 1898, o presidente da província Nogueira Acióli passou a defender uma importante mudança na política de socorros. Segundo ele

[...] os socorros públicos prestados sem plano, urgidos pela crise, se não são inteiramente perdidos para o tesouro federal por melhorarem a sorte dos indigentes, pouco aproveitam na previsão de futuras secas. Enquanto estas perduram é impossível cuidar de economia; a fonte inflexível, exigente e intransigente, e a responsabilidade governamental muito grande. ${ }^{59}$

Acióli não era fiel aos fatos ao afirmar que os socorros públicos eram

\footnotetext{
58 ALVES, Joaquim. História das Secas no Ceará (séculos XVIII-XIX). Ed. fac. símile. Fortaleza: Fundação Waldemar Alcântara, 2003, p. 217.

${ }^{59}$ APEC - Mensagem apresentada a Assembléia Legislativa do Ceará pelo presidente do Estado Antonio Pinto Nogueira Acióli em 4 de julho de 1898. Fortaleza: Tipografia Econômica, 1898, p.26.
} 
prestados sem planos porque eram urgidos pelas secas. $\mathrm{O}$ que ele pretendia era a realização de obras públicas fora dos períodos das secas de modo contínuo e planejado. Com isso, passou-se a defender a separação entre socorros públicos diretos e socorros públicos indiretos. No entanto, ao se aproximar o fim da sua gestão ele tentou indicar o nome do seu filho ao presidente do Brasil Manoel de Campos Sales, com a intenção de encobrir, segundo Rodolfo Teófilo, os seus gastos abusivos e sem explicação do dinheiro da Tesouraria Provincial pacientemente acumulado na gestão do general Bezerril Fontenele (1893-1896).

Mas, o segundo presidente civil Manuel de Campos Sales (18981902) assumiu a presidência do Brasil em meio a uma grave crise econômicofinaceira. O Manifesto Eleitoral de Campos Salles já enfatizava a prioridade no saneamento financeiro da República:

A restauração das finanças é a obra ingente que se impõe às preocupações patrióticas do governo da República. Não há, portanto, lugar para os vastos programas de administração, que, aliás, se incompatibilizam radicalmente com a situação do Tesouro, tal como ela se desenha. Considero por isso um dever de lealdade não abrir esperanças, em contrair compromissos de outra ordem. Muito terá feito pela República o governo que não fizer outra coisa senão cuidar das suas finanças.

Campos Sales foi alertado por Prudente de Moraes quanto à situação crítica das finanças federais. Em meio à sua viagem à Europa, em seguida à vitória eleitoral, em Paris, foi informado que Tootal, gerente do London \& River Plate Bank em Paris, havia feito em nome dos credores, no Rio de Janeiro, proposta relativa a um funding loan. ${ }^{60}$

\footnotetext{
${ }^{60}$ ABREU, Marcelo de Paiva. Brasil, 1824-1857: Bom ou mal pagador? Departamento de Economia: PUC/Rio, texto para discussão (n. 403), agosto de 1999, p.4.
} 
$\mathrm{O}$ acordo foi assinado. O funding loan foi uma medida econômica tomada pelo presidente e seu ministro da Fazenda, Joaquim Murtinho, em 1898. Sales fez uma viagem para a Europa a fim de estabelecer conversações com bancos credores e tentar negociar uma saída para a questão da dívida externa. Entre outras coisas o funding loan estabelecia a concessão de um empréstimo no valor de 10 milhões de libras esterlinas, a ser utilizado para o pagamento dos juros da dívida externa brasileira nos anos seguintes.

Constava do acordo a concessão de um prazo de 10 anos, além dos 3 iniciais para o início do pagamento e a penhora a título de garantia para com os bancos credores, de toda a receita da alfândega do Rio de Janeiro, além de em caso de necessidade, outras alfândegas, das receitas da Estrada de Ferro Central do Brasil e até do serviço de abastecimento de água do Rio de Janeiro e por último a obrigação assumida perante os bancos de sanear a moeda brasileira com o objetivo de estabilizar a economia do país.

Na prática, o funding-loan era um esquema para dar folga e garantir, através de um novo empréstimo, o pagamento dos juros e do montante de empréstimos anteriores. Após do funding-loan muitos bancos nacionais faliram e a posição dos estrangeiros ficou mais forte. O maior banco inglês, o London and Braziam Bank, tinha muito mais recursos do que o Banco do Brasil. Ainda em 1929, os estabelecimentos bancários estrangeiros eram responsáveis por metade das transações financeiras.

Em 1898 o ministro da Fazenda Joaquim Murtinho, tendo que lidar com uma enorme recessão, ${ }^{61}$ mostrava-se profundamente descontente com os gastos de Nogueira Acióli, tanto que por causa disso Murinho indicou Pedro

\footnotetext{
${ }^{61}$ LOPEZ, Adriana, MOTTA Carlos Guilherme. História do Brasil: uma interpretação. São Paulo: Editora SENAC São Paulo, 2008, p.575.
} 
Borges para assumir a presidência do Ceará e desbancar a oligarquia Pompeu Acióli.

Segundo Rodolfo Teófilo Pedro Borges "trouxe ordens terminantes do Rio de Janeiro para desbancar o Sr. Nogueira Acióli, mal visto pelo governo da União pelos esbanjamentos dos dinheiros do estado". ${ }^{2}$ Pedro Borges ao assumir o governo teve nas mãos as provas das práticas corruptas encetadas por Acióli que ao passar-lhe o governo disse a Assembléia Provincial ter deixado nos cofres do estado um saldo de mil contos de réis quando o dinheiro que havia nos cofres, segundo Teófilo, mal dava para pagar as contas processadas.

No entanto, Nogueira Acióli agindo com astúcia fingiu uma enfermidade e chamou para vê-lo o presidente Pedro Borges que também era médico. Na cabeceira da cama do seu antecessor Borges foi convencido a ver o mundo pelo lado prático. Acióli o convenceu a não romper com ele, prometendo-lhe que após deixar o governo seria eleito senador e "assim a vida lhe correria folgada e tranqüila". ${ }^{63}$ Borges assentiu com a proposta de aliança de Acióli descumprindo a ordem do ministro Murtinho de desbancá-lo.

Pedro Borges não apenas não rompeu politicamente com a oligarquia Pompeu Acióli como deu continuidade ao seu modelo de combate às secas iniciado em 1877 haja vista que ele assumiu o a administração do estado sob os efeitos da seca de 1900. Ele declarou no seu relatório que "além da necessidade do momento, a conveniência de prosseguir-se nas medidas já iniciadas durante a seca trienal de 1877 a 1879, completando-se a organização do plano de combate, assentado para atenuar no futuro os rudes golpes da calamidade". ${ }^{64}$

62 TEÓFILO, Rodolfo. Libertação do Ceará: queda da oligarquia Acióli. Ed. fac. sim. Fortaleza: Fundação Waldemar Alcântara, 2001, p.9.

${ }^{63}$ Ibid., p. 11.

${ }^{64}$ APEC - Mensagem apresentada à Assembléia Legislativa do Ceará pelo presidente do estado 
Pedro Borges reapresentou o projeto Pompeu Sinimbú ao presidente Manoel de Campos Sales tornado oficial em 1878. Duas décadas depois, o projeto apesar de vir sendo implementado, foi recolocado num documento oficial. Borges transcreveu trechos inteiros da mensagem do Conselho de Estado dirigida ao rei em 1878 pelo visconde de Sinimbú na sua mensagem à Assembléia Provincial em 1901. Assim, diante de mais uma seca devia-se:

Tirar vantagem da própria desgraça, empregando em trabalhos úteis tantos braços ociosos, estabelecer um sistema de serviço que, sobre assegurar a essa população meios de subsistência, alimentasse o seu amor ao trabalho, mediante razoável gratificação, - tal o pensamento fundamental do ato do governo. ${ }^{65}$

Não obstante, a pretensão do presidente Nogueira Acióli de realizar obras públicas fora dos períodos de secas ganhou o apoio do presidente Pedro Borges que consolidou essa proposta num nível institucional. Essa pretensão representou uma evolução no projeto Pompeu Sinimbú, quando o senador Pompeu propôs que se condicionasse o socorro indireto ao socorro direto. $\mathrm{Ou}$ seja, que os desvalidos das secas para receberam os gêneros alimentícios tivessem que prestar serviço em alguma obra pública.

Para avaliarmos o êxito dessa proposta teremos que acompanhar a progressão da seca de 1900. No final do mês de maio, reuniu-se a representação cearense no Congresso Federal, acertando o conjunto de medidas consideradas profícuas para se executar um "plano geral de assistência pública, que correspondesse no seu elevado alcance, à garantia constitucional dos socorros

Pedro Augusto Borges. Fortaleza: tipografia Econômica, $1^{\circ}$ de julho de 1901, p.30. ${ }^{65}$ Ibid. 
públicos". ${ }^{66}$ Pedro Borges juntamente com os representantes cearenses se dirigiu ao presidente da República, Manoel de Campos Sales, solicitando socorros públicos à província pelo regime indireto de trabalho. Borges após se inteirar da situação passou a organizar um plano de assistência pública com "a prestação dos socorros com a utilidade dos serviços". ${ }^{67}$

O processo de debate na Câmara e no Senado para a aprovação de recursos para socorrer aos desvalidos na seca de 1900 é importante para avaliarmos a força das elites cearenses. O projeto de socorros apresentado pelo deputado Francisco Sá à Câmara dos Deputados previa um crédito de 10 mil contos de réis para socorrer as províncias do Norte, mas que de fato se destinavam apenas ao Ceará "sendo preferidas, na prestação de socorros, obras de utilidade pública para nelas serem empregados os braços desocupados, os desfavorecidos da fortuna". ${ }^{68}$

Somente em outubro o projeto cumpriu o trâmite necessário passando pela Câmara e pelo Senado. No entanto, o motivo do seu atraso foi que parlamentares de outras províncias tentaram aprovar emendas garantindo que parte dos recursos fosse para os seus estados, porém curiosamente como notou a Comissão de Finanças do Senado, os outros governadores não solicitaram auxílios e o "governo assim confirmou na sua informação quando declarou que o presidente do Ceará fora o único que solicitara esses auxílios". ${ }^{69}$ No entanto, a Comissão de Finanças do Senado tentou a manobra de definir que os socorros destinados deveriam se restringir à concessão de passagens aos cearenses para

\footnotetext{
${ }^{66}$ Ibid., p. 23.

${ }^{67}$ Ibid., p.24.

${ }^{68}$ Ibid., p.34.

${ }^{69}$ Ibid., p.36.
} 
fora da província como ocorrera na secas anteriores, sobretudo na de $1888-89 .{ }^{70}$

Sem conseguir dividir os créditos entre outros estados do Norte a Comissão de Finanças do Senado tentou a manobra de boicotar o projeto do deputado Francisco Sá de utilizar a verba para o socorro por meio de obras públicas. O presidente respondeu a Pedro Borges dizendo-lhe "não ser possível, ante a própria natureza do flagelo, uma medida de efeitos completos, sobretudo quando outros estados, como Piauí e Rio Grande do Norte, em circunstâncias idênticas fazem iguais solicitações". ${ }^{71}$

A disputa de outros estados pela verba dos socorros levou a embates acirrados na Câmara e no Senado, fazendo com que o presidente Campo Sales enviasse um telegrama a Pedro Borges pedindo-lhe prudência, pois os representantes desses estados eram reclamantes, como destacou o presidente, com atitudes altamente inconvenientes, no momento em que os poderes federais e estaduais, que teriam que "combinar sua ação, afim de torná-la benéfica, pois não era só a União que cabe responder por esta angustiosa situação", ${ }^{72}$

De certo modo, já havia uma diferença entre a aprovação de créditos para a seca de 1900 e as anteriores. Nesta o socorro veio muito tarde, somente em setembro, e com isso o crédito aprovado seria suficiente para o término desse ano e para o ano seguinte. Não obstante, a aprovação de créditos em setembro para uma seca que havia sido declarada com base no equinócio de março, o crédito foi entravado com emendas e prolongadas discussões. Corria-se o risco da seca acabar antes dos créditos serem definitivamente aprovados. Pedro Borges temendo o atraso escreveu ao presidente da República afirmando

\footnotetext{
${ }^{70}$ NOZOE, Nelson et. alli. Os refugiados da Secas: emigrantes cearenses, 1888-1889. São Paulo; Campinas: NEHD, NEPO, CEDHAL, 2003, p.11.

${ }^{71}$ APEC - Mensagem apresentada à Assembléia Legislativa do Ceará em 1 de julho de 1901 pelo presidente do Estado Pedro Augusto Borges. Fortaleza: Tipografia Econômica, 1901, p.37. ${ }^{72}$ Ibid., p.38.
} 
que "a seca que flagela o Ceará tocou o seu auge". 73

O senador Joaquim Katunda repeliu com indignação a proposta da divisão da verba no que foi seguido pelo coronel José Bezerril. ${ }^{74}$ Pedro Borges escreveu novamente ao presidente Campo Sales criticando a manobra da Comissão de Finanças do Senado de carimbar a verba para a migração, dizendolhe que:

[...] a prestação dos socorros restrita a emigração dos cearenses, como opinam governo e a comissão de finanças do Senado, repercutiu dolorosamente no espírito público, porque, na extensão do seu efeito, seria o despovoamento do Ceará, em proveito exclusivo de outros estados. ${ }^{75}$

Ele argumentava que se o crédito fora aprovado para socorrer o estado na calamidade, isso devia ser feito mantendo os cearenses no estado e por meio de um sistema de assistência pública por meio do trabalho, acudindo-se as vítimas do flagelo na sede do seu domicílio. Ele relembrou ao presidente que havia indicado a migração como um expediente provisório e não como permanente. A tentativa da comissão de finanças do Senado era evitar o aproveitamento de uma quantidade tão grande de recursos que a princípio deveriam socorrer as populações do Norte, mas que de fato seriam destinados única e exclusivamente ao governo do Ceará.

O parecer da Comissão de Finanças do Senado foi reprovado em votação, passando integralmente o projeto de socorros que vinha da Câmara e aprovava um crédito de 10 mil contos de réis destinados exclusivamente ao

\footnotetext{
${ }^{73}$ Ibid, p.34.

${ }^{74}$ SOBRINHO, Tomaz Pompeu. História das Secas (Século XX). 2a ed. Coleção Mossoroense, vol. CCXXVI, 1982, p.194.

${ }^{75}$ APEC - Mensagem apresentada à Assembléia Legislativa do Ceará pelo presidente do Estado Pedro Augusto Borges. Fortaleza: Tipografia Econômica, em $1^{\text {o }}$ de julho de 1901, p.37.
} 
Ceará. De fato, as elites políticas do Norte, mormente as do Ceará como notou Durval Muniz, descobriram a força da arma que tinham nas mãos: o fenômeno da seca e o cortejo de misérias que ela desencadeava tornavam esse tema "um argumento quase irresistível na hora de se pedir recursos, em nome de socorrer as vítimas do flagelo, obras públicas, em nome de organizar e promover a distribuição dos socorros". 76

A emigração não foi eliminada, é certo, do plano do governo na prestação de socorros, mas não esteve sob a ação aguda das pontas do dilema ou o êxodo ou a morte. Pedro Borges era contra o que ele chamava de socorrer expatriando. Dizia que o plano do governo geral de socorrer por meio da concessão de passagens para fora do estado, forçava os habitantes a se mover desordenadamente dos pontos mais centrais e remotos do interior para o litoral, "fazendo taboa rasa do seu lar, em busca de outros Estados, para onde partem desapercebidos de qualquer meio de subsistência". ${ }^{77}$

O plano das elites do Norte de em tempos se seca facilitar a migração dos cearenses, de fato fazia tábua rasa do lar dos sertanejos, no entanto, o plano de socorros centralizados, defendido por Pedro Borges e por todos os presidentes anteriores que aplicaram o projeto Pompeu Sinimbú sempre fez tábua rasa do domicílio do sertanejo, porém de modo interno.

O que Pedro Borges defendia era o direito do estado do Ceará controlar a migração interna, decidir o que fazer com o retirante que abandonava o seu domicílio. Socorrer expatriando, como queriam as elites do Sul inviabilizaria o projeto Pompeu Sinimbú, meio encontrado pelas elites

\footnotetext{
${ }^{76}$ ALBUQUERQUE JR., Durval Muniz de. Preconceito contra a origem geográfica e de lugar: as fronteiras da discórdia. São Paulo: Cortez, 2007, p.92.

${ }_{77}$ APEC - Mensagem apresentada à Assembléia Legislativa do Ceará pelo presidente do Estado Pedro Augusto Borges. Fortaleza: Tipografia Econômica, em 1 de julho de 1901, p.39.
} 
cearenses, de equacionarem as diferenças materiais entre as províncias das duas regiões.

\section{2. - Plano de Socorros Estáveis e Completos (PSEC).}

Nogueira Acióli sucedeu a Pedro Borges e deu continuidade ao seu Plano de Serviços Estáveis e Completos, passando a criticar a política de esforços intermitentes e sem continuidade dos trabalhos públicos, defendendo a "adoção de um plano maduramente estudado e persistentemente levado a efeito". ${ }^{78}$ Como justificar a aplicação de um plano intersecas, sendo que durante décadas a existência das secas foram a principal justificativa para se gastar recursos públicos com as obras da província? Uma das justificativas era que as secas eram periódicas e imprevisíveis, portanto as obras deveriam ter uma natureza preventiva. Segundo, as obras iniciadas e não concluídas representavam um desperdício de recursos com a destruição das mesmas pelas chuvas torrenciais.

O Plano de Serviços Estáveis e Completos (PSEC) ao qual nos referimos neste tópico não começou com o presidente Pedro Borges. Como vimos anteriormente Nogueira Acióli propôs na seca de 1898 que os socorros não fossem prestados sem plano e na urgência de uma crise porque embora não fossem investimentos perdidos, pois socorriam aos desvalidos pouco servia para prevenir futuras secas. Com isso se dissociava socorro direto ao atendimento durante a seca e socorro indireto ao atendimento pós-secas ou entre-secas.

As elites técnicas e políticas perceberam que o socorro indireto era

\footnotetext{
${ }^{78}$ APEC - Mensagem apresentada à Assembléia Legislativa do Ceará pelo presidente do Estado Pedro Augusto Borges. Fortaleza: Tipografia Econômica, em 1 de julho de 1901, p.44-45.
} 
mais interessante do ponto de vista político e econômico. É importante observar que quando o projeto Pompeu Sinimbú começou a ser implementado, o socorro direto e o socorro indireto eram interdependentes, pois a condição para o desvalido receber o socorro direto (os gêneros) era o socorro indireto (as obras).

O engenheiro geral das obras da província Ernesto Antonio Lassance Cunha escreveu em 1900 um opúsculo intitulado "Estudos Sobre a Seca do Ceará" que foi publicado no jornal Correio do Povo de Porto Alegre, quando observou que se era impossível evitar os efeitos das secas era possível minorar os seus efeitos. Porém, na sua opinião havia imprevidência por parte dos governos que só se "lembravam das secas quando têm de abrir os cofres para completar a miséria do faminto, desmoralizando-o com a esmola, como socorro público". ${ }^{79}$ Ele também passou a defender a realização de obras públicas fora dos períodos de secas.

Kênia Sousa Rios avaliou que os membros da Comissão Científica de Exploração que escreveram sobre a seca a partir de 1877

[...] pouco sabiam sobre (e não presenciaram) os benefícios advindos da calamidade. Se Capanema tivesse maiores informações sobre os usos das secas para o melhoramento da capital, talvez acrescentasse ao seu texto considerações sobre alguns motivos para o retardamento da resolução dos problemas oriundos da seca. ${ }^{80}$

Porém, as coisas não se deram exatamente assim, pois Capanema e vários outros membros da Comissão Científica conheciam e criticavam abertamente a política de socorros empregada. Por outro lado é preciso pensar essa política em longo prazo, considerando a dependência que ela instaurou de

\footnotetext{
${ }^{79}$ ALVES, Joaquim. História das Secas (séculos XVIII ao XIX). Ed. Fac-símile. Fortaleza: Fundação Waldemar Alcântara, 2003, p.232.

${ }^{80}$ RIOS, Kênia Sousa (org). A Seca no Ceará: escritos de Guilherme Capanema e Raja Gabaglia. Fortaleza: Secretaria de Cultura do Estado do Ceará, Museu do Ceará, 2006, p.29.
} 
toda uma região em relação ao governo federal.

O barão de Capanema escreveu um texto em 1901, intitulado “A Seca no Norte", no qual ele retoma as idéias apresentadas em 1859-1861, 1877 79. Ele pôde avaliar os resultados obtidos pelo uso da seca para a realização do progresso material, pois sempre fora a favor do incentivo e do desenvolvimento econômico pautado no trabalho e nas atividades produtivas. O barão chegou a elogiar o uso dos trabalhadores desvalidos em obras públicas, porém isso não era solução nem para o problema das secas nem para o atraso econômico da região.

[...] ficou resolvido o problema de por uma população inteira ao desabrigo da miséria, com o resultado de conseguir em compensação obras de utilidade pública muito economicamente: morigerar um povo inteligente, subtraí-lo à escola de vícios e de perversidade que se adquire na vida ociosa e más companhias. ${ }^{81}$

Concluiu Kênia Sousa Rios que no ano em que Capanema publicou seu texto "essa prática já estava consolidada". ${ }^{82}$ Essa prática foi como já explicamos o cerne do projeto Pompeu Sinimbú. Assim, como houve uma explícita retomada do projeto Pompeu Sinimbú em 1900 com Pedro Borges transcrevendo no seu relatório ao presidente da República a mensagem de 1878, na qual o visconde de Sinimbú oficializou os termos do projeto de explorara a mão de obra sertaneja na execução de obras públicas, Guilherme Capanema publicou em 1901 um texto intitulado "A Seca do Norte", no qual retomou algumas idéias presentes nos “Apontamentos sobre secas do Ceará”, publicado em 1878.

\footnotetext{
${ }^{81}$ CAPANEMA, Guilherme. A Seca no Norte. Rio de Janeiro: Imprensa Nacional, 1901.

${ }^{82}$ RIOS, Kênia Sousa. Op. cit, p.28.
} 
Houve também uma retomada das observações de 1859 a 1861, quando ele fizera parte da Comissão Científica de Exploração, e nas cartas, ainda inéditas, que destinou ao rei D. Pedro II por que o Ceará que encontrou em 1860 apresentou pouca diferença em 1884 no que tange a seca. Isso, não quer dizer que nesse interregno Capanema parou de observar as províncias do Norte. Em 1885 ele esteve no Ceará e no Piauí para inaugurar o telégrafo em Teresina, ligando o Parnaíba ao Rio da Prata. ${ }^{83}$

Capanema via o Ceará e as províncias do Norte como o lugar de uma contradição. Ele inicia seu texto dizendo "Ceará! Ceará! Terra da fartura e da miséria! Alternado perpetuamente sem nunca despertar o letargo daqueles que tinham o dever de com o excesso de uma abafar a impetuosidade da outra". ${ }^{84}$ Para o barão de Capanema o Ceará era um "país de uma produção prodigiosa, superabundante, onde o solo se esforça por produzir, como por encanto, uma pujante vegetação que se desenvolve com vertiginosa rapidez!". ${ }^{85}$

Mesmo, num terreno pedregoso, seco, coberto de arvoredo, com troncos denegridos, sem uma folha, que produziria a impressão de uma natureza morta ele encontrou uma atordoadora algazarra de papagaios, periquitos, jacus, quero-queros, xexéus, corrupiões e bandos de pombas que revelam a existência da vida, de uma natureza animada, cujos habitantes se nutrem das sementes gramíneas torradas, que o vento espalha como leve poeira.

Guilherme Capanema após tecer considerações sobre a população cearense, seus costumes, o advento da política, a força do sertanejo, a alimentação básica mostrou o descuido, a imprevidência e os desatinos administrativos cometidos em relação às condições anormais no tempo das

\footnotetext{
${ }^{83}$ CAPANEMA, Guilherme. Op. cit., p. 208.

${ }^{84}$ Ibid.,p.110

${ }^{85}$ Ibid., p27.
} 
secas. Na sua compreensão a seca não era uma anomalia, pois segundo ele as secas eram "um indispensável elemento para a manutenção da prodigiosa fertilidade daquele solo". ${ }^{86}$

Para ele era inútil tentar combater as seca, "seria apenas lembrar D. Quixote atacando o moinho de vento". Elas fatalmente se reproduzem ${ }^{87}$ No entanto, era possível evitar os seus efeitos e em tempo procurar outras regiões do país que fornecessem contra elas o abrigo, ou precaver-se com os recursos necessários para arrostá-los, o que era fácil, e disso havia exemplos, ${ }^{88}$ como o dos índios dos confins da Paraíba do Norte.

Quando estes precisavam migrar devido à escassez da caça entulhavam de pedra o poço, cobrindo-as de cisco para outros não darem com o lugar. Quando retornavam, desentulhavam o poço, tiravam toda a água, limpavam-no cuidadosamente, cercando-o para nem mesmo os cães beberem daquela água, que caprichavam manter limpa. "Estes homens sem civilização eram previdentes". ${ }^{89}$

Outro exemplo de previdência Capanema recebeu de Ferdinand Denis. Ele mencionou a descrição que fizera um viajante, dos zonotes que encontrara no Yucatã, onde reinam secas periódicas: são estes vastas cisternas fundadas no meio de um grande terreiro ladrilhado para colher as águas da chuva. Segundo uma notícia que leu novos ocupantes tratam de limpar esses zonotes já coberto de terra e de vegetação, a fim de os aproveitar para reservatórios de água.

No Ceará tais reservatórios seriam úteis, porém devendo ser

\footnotetext{
${ }^{86}$ CAPANEMA, Guilherme Schüch. A Seca do Norte, Rio de Janeiro: Imprensa Nacional, 1901, p. 197.

${ }^{87}$ Ibid., p.200

${ }^{88}$ Ibid, p. 200.

${ }^{89}$ Ibid, p. 201.
} 
acompanhados de outras medidas: água nunca falta inteiramente, mas os cereais indispensáveis para alimentação desaparecem completamente por criminosa incúria. Mas, no Norte "Aguarda-se o aparecimento da calamidade, não se cura de recursos para evitar os seus desastrosíssimos efeitos". ${ }^{90}$ Além disso, a seca atingia a população física e moralmente.

Quanto não sofrem as mães debilitadas com os filhinhos agarrados aos seios sem uma gota de leite! Desesperadas, elas, para se alimentarem, arrancam raízes às vezes venenosas, esforço extremo para prolongar uma dolorosa agonia. E quanto sofrem as vítimas da maldade e da torpe vileza de monstros com forma humana que escarnecem da mais atroz miséria e oferecem em troca da honra um punhado de farinha que o governo manda em socorro dos infelizes! $\mathrm{E}$ não raro deteriorada!. ${ }^{91} \mathrm{~A}$ fotografia perpetuou o aspecto desses desgraçados, apresentando esqueletos ambulantes, cobertos de peles murchas, caras que já são caveiras, representam figuras que lembram as múmias do Egito ou as guanches das cavernas de Tenerife, só com a diferença de não serem imóveis". ${ }^{92}$

Essa era uma conseqüência do projeto Pompeu Sinimbú que não apenas se baseou no abandono dos domicílios por parte dos retirantes como levou modificação da política econômica como o incentivo à manufatura e o abandono da agroexportação. Capanema em 1901 dizia que Quando esse quadro medonho e repugnante se oferece, abrem-se os cofres públicos, recorrese à caridade do povo e oferecem-se meios de fugir do lar! ${ }^{93}$

Capanema indicou novamente em seu artigo em 1901 o seu sistema de stocks como o meio mais eficaz para armazenar a água, era a criação de

\footnotetext{
${ }^{90}$ Ibid, p. 201.

${ }^{91}$ Ibid., p.201- 202.

${ }^{92}$ Ibid., p. 202.

${ }^{93}$ Ibid.
} 
cisternas. A diferença entre as cisternas e os açudes era que estes últimos implicavam no abandono dos domicílios. Quanto ao problema da falta de alimentos durante as secas que criava uma crise de abastecimento ele propôs a criação dos depósitos de mantimentos incitando o povo a cultivar a maior parte de cereais que fosse possível, para ter sobras destinadas aos depósitos, que devem servir para consumo durante as secas. Quanto ao gado que morria de fome pela falta de pasto ele indicou os depósitos de forragem porque no "Ceará, havia uma abundância de pastos de excelentes forragens, que dão muito e bom feno". 94

A seca de 1900 Pedro Borges garantiu o socorro por meio de obras publicas, evitou a concentração dos retirantes na capital cearense, evitou a migração para fora do Ceará um problema sério na seca de 1888-89 e deu continuidade às obras que ficaram inacabadas na seca anterior. Porém, a um elemento comum a todas essas secas que o suposto de que elas são imprevisíveis em longo prazo, tornando inviável a tomada de precauções.

O presidente respondeu a Pedro Borges dizendo-lhe "não ser possível, ante a própria natureza do flagelo, uma medida de efeitos completos, sobretudo quando outros estados, como Piauí e Rio Grande do Norte, em circunstâncias idênticas fazem iguais solicitações". 95 A disputa de outros estados pela verba dos socorros, levou a embates acirrados na Câmara e no Senado, levando a que o presidente Campo Sales enviasse um telegrama a Pedro Borges pedindo-lhe prudência, pois os representantes desses estados eram reclamantes, como destacou o presidente, com atitudes altamente inconvenientes, no momento em que os poderes federais e estaduais, que teriam

\footnotetext{
${ }^{94}$ Ibid.

95 APEC - Mensagem apresentada à Assembléia Legislativa do Ceará em 1 de julho de 1901 pelo presidente do Estado Pedro Augusto Borges. Fortaleza: Tipografia Econômica, 1901, p.37.
} 
que "combinar sua ação, afim de torná-la benéfica, pois não era só a União que cabe responder por esta angustiosa situação". 96

Um outro aspecto importante da seca de 1900 é a diferenciação entre socorro direto e socorro indireto. O socorro direto era aquele prestado pelo comissário quando entregava um saco com gêneros de primeira necessidade ao retirante. Já o socorro indireto era aquele que o indivíduo recebia por meio do trabalho. Paulatinamente, o socorro indireto vai se sobrepor ao direto com a criação de órgão federais ligados a construção de obras públicas. "O que é essencial, seja-me lícito repetir, é a organização de um plano de serviços, cuja execução não seja interrompida ou suspensa, mas perseverantemente continuada, a fim de dotar o Ceará com os meios indispensáveis adequados a afrontar os males que as secas lhe reservem no futuro". ${ }^{97}$

Após tomar conhecimento da situação da província em relação a calamidade da seca Pedro Borges escreveu ao presidente dando-lhe informações. A partir da p. 25 exposição da seca ao presidente Pedro Borges alegou a falta de recursos para socorrer os desvalidos, mas não atribuiu esse fato à gestão fraudulenta do seu antecessor - Nogueira Acióli - que informou no seu relatório haver deixado no cofre do Tesouro Provincial mil contos de réis. As medidas mais indicadas para Pedro Borges eram a construção de açudes, para a irrigação de terrenos e as estradas de ferro que concorreriam para que não se “desloquem as populações do interior, que ainda poderão aguarda nos lugares de suas residências os socorros que lhes tenham de ser prestados pelo poder público". 98

\footnotetext{
${ }^{96}$ APEC - Mensagem apresentada à Assembléia Legislativa do Ceará em 1 de julho de 1901 pelo presidente do Estado Pedro Augusto Borges. Fortaleza: Tipografia Econômica, 1901, p.38. ${ }_{97}$ Ibid., p.27-28.

${ }^{98}$ Ibid., p.26.
} 
Entre as obras desse plano os serviços estáveis apresentado por Pedro Borges estava o prolongamento da estrada de ferro de Baturité até o vale do Cariri e a construção de um grande açude no Boqueirão das Lavras.

Entretanto, sem adotar-se um plano de serviços estáveis, levados a execução com perseverança, com a decretação de verbas possíveis nos orçamentos anuais para seu custeio até completar-se o conjunto das medidas tendentes a neutralizar os efeitos da calamidade, em qualquer tempo ou período em que ela venha a renovar-se, ter-se-á apenas atacado o mal, quando surge, para abandoná-lo, quando cessa, sem cuidar do futuro. ${ }^{99}$

Mas, enquanto o Governo Federal não destinava recursos a saída que Pedro Borges tinha, contra sua vontade, era facilitar a emigração para as províncias do Amazonas e do Pará. Mesmo o Governo Federal destinando recursos à assistência aos desvalidos havia um interesse de outros estados em receber a mão de obra migrante. Por isso, Pedro Borges argumentava em mensagem a Assembléia Legislativa que se a calamidade pública, era um grande mal intenso e generalizado, que reduzia ao as forças e as energias de um Estado, desequilibrando-lhe o organismo, atacando-lhe os elementos de produção, e cuja duração poderia até comprometer a sua existência política, concluiu que socorrer um Estado, por ocasião de alguma calamidade, era "tentar salvá-lo na sua integridade, e não mutilá-lo na sua população, que lhe é vida”. ${ }^{100}$

Segundo ele, era como o estado desse aos seus cidadãos um mandado de despejo, que afetava o seu direito de locomoção, por meio da emigração forçada devido à falta de assistência ou desta ser insuficiente com um socorro prestado fora da sede do domicílio ou dos limites territoriais do próprio estado.

\footnotetext{
${ }^{99}$ Ibid., p. 27.

${ }^{100}$ Ibid., p.40.
} 
Para Pedro Borges o governo Federal deveria a estabilidade do domicílio, por meio do socorro completo, pois a migração para fora dos limites do estado excluía o desvalido do seu direito de liberdade de opção, causando-lhe constrangimento moral. Esse tipo de argumento, apenas mascarava o real interesse dos governos ligados a oligarquia Acióli e, por conseguinte ao projeto Pompeu Sinimbú que era o de gerir e controlar os retirantes.

O abandono do domicílio era a base para o projeto, no entanto os retirantes deveriam migrar apenas internamente, pois se eles abandonassem o estado, as comissões de socorros perderiam sua importância e se deixaria de aproveitar os braços ociosos na construção de obras públicas, que fariam a riqueza de outras províncias. Pedro Borges Pedia ao governo Federal a concessão de passagens aos retirantes como medida provisória até que chegassem as verbas para aplicar as medidas permanentes como a construção dos açudes e das estradas de ferro. No entanto, quando foram aprovados os créditos necessários Pedro Borges fez cessar a migração para outras províncias, porque senão a migração se converteria em medida de despovoamento do solo.

Obedeci, além da necessidade do momento, à conveniência de prosseguir-se nas medidas já iniciadas durante a seca trienal de 1877 a 1879, completando-se a organização de um plano de combate, assentado para atenuar no futuro os rudes golpes da calamidade. ${ }^{101}$

Em 14 de agosto o ministro da Viação e Indústria mandou um telegrama ao presidente informando-lhe a disposição de recursos para o socorro da província. No entanto, os recursos que o governo disponibilizava eram no sentido de fornecer passagens aos retirantes nos vapores do Lhoyd, dos agricultores e das suas famílias que quisessem se estabelecer nos estados do Sul

\footnotetext{
${ }^{101}$ Ibid., p. 30.
} 
da República, podendo ir a cada viagem até 300 passageiros.

Entretanto, começou-se a conjeturar que estava grassando no Sul do País uma espécie de febre com as características de peste bubônica semelhante às febres que grassavam entre os retirantes acolhidos em Fortaleza. Com isso, o deputado Francisco Sá conseguiu aprovar um projeto de socorros mais enérgicos de combate à seca. O deputado Francisco Sá escreveu a Pedro Borges querendo saber quanto ele precisava para socorrer aos desvalidos. Borges disse-lhe que a seca era generalizada, com todos os municípios sentindo os seus efeitos, e que era difícil fixar um valor porque não sabia quanto tempo a seca iria durar. Pediulhe que os recursos fossem sendo enviados à medida das necessidades.

Indicava a Francisco Sá que as verbas seriam para o prolongamento das estradas de ferro de Baturité e Sobral além dos grandes açudes. Desse modo, Borges começava a por em evidência o seu plano de socorros estáveis. Ele não pretendia delimitar um prazo para o fim dos socorros e ao apresentar a continuação de obras de grande vulto como essas estradas ele indicação sua intenção pelos socorros indeterminados. No fim de sua mensagem escrevia ao deputado, dizendo-lhe que o "Bacteriologista Miranda prossegue com a máxima discrição seus estudos sobre moléstia suspeita, cujo diagnóstico, por ora não foi possível afirmar". ${ }^{102}$

Com isso, o subdesenvolvimento do Nordeste em relação ao Sul residiu em três fatores: no deslocamento do eixo econômico voltado o setor cafeeiro, na implantação no Ceará de 1869 a 1905 de um projeto de equiparação material baseado na exploração da mão de obra pobre e livre durante as secas, e no fortalecimento de uma elite regional que teve como bandeira política a

\footnotetext{
${ }^{102}$ Ibid, p.33.
} 
questão das estiagens, cujo embrião foi o Ceará. O projeto Pompeu Sinimbú preconizava que mão de obra abundante durante as secas fosse empregada na realização de obras públicas.

Nogueira Acióli em 1905 passou a utilizar o modelo inglês de combate às secas na Índia para justificar a construção de açudes e estradas de ferro no Norte do Brasil. O governo inglês recomendou aos governos de Bombay e Madras por ocasião da seca de 1876 que organizassem pequenas obras de socorros (small relief Works), em número suficiente para empregar toda a população indigente dos distritos favelados, o mais próximo possível dos domicílios, a fim de trabalharem homens, mulheres e crianças. Entre as obras indicadas foram preferidas a construção de estradas (roads), açudes (tankes), poços (wells). Prolongando-se além do termo esperado os efeitos da calamidade, o governador de Bombay lembrou ao governo metropolitano a utilidade de dar a tais obras um caráter mais geral e permanente.

No entanto, o equívoco de Acióli reside em comparar dois projetos de socorros muito diferentes. O projeto Pompeu Sinimbú tinha um fim em si mesmo, enquanto a proposta do Lorde Salisbury se relacionava à necessidade de socorrer os trabalhadores e plantadores de chá. Apesar da proposta de Salisbury de socorro por meio de obras públicas, havia uma clara determinação por parte do governo inglês aos governadores de Bombaim e Madras por ocasião da seca de 1876, que organizassem os small relief works (pequenas obras de socorro) para empregar a população indigente dos distritos flagelados "o mais próximo possível dos domicílios". ${ }^{103}$ Nesse aspecto, o plano de socorros do Salisbury foi menos cruel que o das elites cearenses por não depender do abandono dos

\footnotetext{
${ }^{103}$ APEC - Mensagem dirigida à Assembléia Legislativa do Ceará em 1 de julho de 1905, p.45.
} 
domicílios.

Por isso, Renato Braga observou que sempre lhe "causou estranheza o silêncio dos estudiosos cearenses a respeito da Comissão Científica de Exploração". O motivo de sua estranheza era, como ele próprio, observou, o fato da Comissão ter estado no Ceará durante mais de dois anos, percorreu a Província em todos os sentidos, procurando realizar um amplo programa de investigações, "o primeiro a ser tentado no Império por um grupo de naturalistas e técnicos exclusivamente brasileiros". ${ }^{104}$

Renato Braga foi perspicaz ao dizer que a Comissão Científica de Exploração "nasceu de uma idéia generosa, mas acima da compreensão do governo e do povo" ${ }^{105}$, e por isso "viveu, e se foi sem deixar traços de sua existência. Não passou de um belo plano frustrado nas suas esperanças". 106 Mas, esse projeto perdedor deixou sim traços da sua existência não na memória política ou popular, mas nos documentos de arquivos e museus, que não permitem ao historiador fazer tábua rasa do seu passado. E sua superação por outro projeto permite uma comparação entre o que aconteceu e o que poderia ter acontecido se ele tivesse sido implementado. A história das secas no Ceará não poderá prescindir do projeto Capanema sempre que se ouvir falar em nordestino ou nordestinidade de forma pejorativa. Ou quando tais expressões forem associadas à miséria, à fome, à prostituição e ao desvario. Se me é permitido o trocadilho, o Ceará teve o seu destino malogrado porque trocou uma comissão de exploração da natureza por uma comissão de exploração das pessoas.

Thomaz Pompeu Sobrinho, em 1912, numa memória justificativa

${ }^{104}$ BRAGA, Renato. História da Comissão de Exploração. Imprensa Universitária: Fortaleza, 1962, p.106.

${ }^{105}$ Ibid.

${ }^{106}$ Ibid. 
dirigida ao Inspetor de Obras Contra as Secas (IOCS), observou que por uma questão físico-social os estados do Norte na segunda metade do século XIX se retardaram sensivelmente no movimento evolutivo da Nação. ${ }^{107} \mathrm{O}$ problema foi que esse órgão resultou de uma preocupação apenas com os aspectos físicos da seca, descurando completamente do social. Para o diretor da IOCS esse tipo de alegação não tinha importância porque ele fora criado apenas para cuidar do atraso físico. Ele compreendeu as raízes do subdesenvolvimento nordestino, mas foi incapaz de atribuir-lhe a elite familiar da qual pertencia ou por incompreensão histórica ou por não querer ofender a memória dos seus antepassados.

Tomaz Pompeu Sobrinho no seu estudo sobre as secas na primeira metade do século XX observou que "ainda continuamos a oferecer às vítimas das secas, como recursos mais geral e imediato, a desastrosa fuga, o abandono forçado dos lares! Se progresso houve, foi no sentido de podermos fazer isso com mais generalidade e um pouco mais de oportunidade". ${ }^{108}$ A ironia do destino é que foi justamente o antepassado mais famoso dele - o senador Pompeu - quem estabeleceu as bases de um projeto de desenvolvimento econômico que dependia do abandono dos domicílios para ser exeqüível. Mas, Tomaz Pompeu Sobrinho não deve ser responsabilizado pelo malfadado projeto das elites cearenses porque ele próprio denunciou seus malefícios.

Ele compreendeu, assim como o barão de Capanema que as "devastações de uma seca rigorosa, no seio de uma sociedade de cultura inferior, podem ser irreparáveis; menos graves será nas de cultura média e passarão

\footnotetext{
${ }^{107}$ SOBRINHO, Thomaz Pompeu. "Açude Quixeramobim". Revista do Instituto do Ceará. Ano XXVI, 1912, p.215 - 279.

${ }^{108}$ Id. História das Secas (Século XX). 2 2a ed. Coleção Mossoroense, vol. CCXXVI, 1982, p.11.
} 
quase desapercebidas nas de uma cultura refinada". ${ }^{109}$ O projeto do barão de Capanema se baseava fundamentalmente em melhorar a cultura da população trabalhadora dos campos. Se isso tivesse sido levado adiante a seca passaria despercebida, mas ao revés o que se viu no século XIX e na primeira metade do século XX foi o contínuo abandono dos domicílios, o sofrimento da população migrante e as aviltações sociais, pois o projeto Pompeu Sinimbú continuou e teve início uma segunda fase - a institucionalização das secas por meio da sobrevalorização dos socorros públicos indiretos.

O projeto do barão de Capanema se baseava em grande parte no ensino agrícola. Por isso, Francisco Alves de Andrade ao resgatar as origens e pesquisas das ciências agrárias no Ceará atribuiu seu início com a vida da Comissão Científica de Exploração em 1859. Guimarães Duque observou o descompasso entre o processo de modernização da agricultura ocorrida no país e o atraso cultural do trabalhador cearense.

A tentativa da solução incompleta das questões rurais, no Ceará, pela açudagem, pelas estradas, pelo fomento agrícola e pela alfabetização parcial, sem considerar a estrutura social dos agrupamentos humanos nos seus costumes, desejos, tendências, e ambições nos levou a enfrentar hoje uma multiplicidade de assuntos, que constituem uma prova de fogo para os governos, para os administradores, para os técnicos, para os pensadores. ${ }^{110}$

A linha cronológica do processo de institucionalização do problema das secas obedece a seguinte ordem: SEOCS (1901), IOCS (1909), IFOCS (1919) DNOCS (1945) e SUDENE (1959). O que todos esses organismos tiveram em comum foi a presença do estado investindo no progresso e/ou no desenvolvimento da região. É importante ressaltar que não confundimos

\footnotetext{
${ }^{109}$ Ibid., p.8.

${ }^{110}$ DUQUE, Guimarães. "A Colonização Agrícola Racional do Ceará". Revista do Instituto do Ceará. Ano LXXI, 1957, p.166.
} 
progresso material como desenvolvimento. A noção de progresso material vigente no século XIX se ateve à aquisição de infra-estrutura e melhoramento tecnológico numa economia agro-exportadora. Já o conceito de desenvolvimento se refere ao processo de industrialização. Entretanto, seja no contexto do século XIX ou no do XX a preocupação foi basicamente a mesma: a diferença do progresso econômico entre as regiões Norte e Sul do Brasil formando algo que Odilardo Viana de Avelar Jr., denominou de "clube da calamidade". 111

Rodolfo Teófilo se opôs veementemente às propostas feitas pelo barão de Capanema com relação às secas no Norte. Propostas cuja essência era a adoção de medidas preventivas por parte da população durante as secas. Escrevendo sobre a seca de 1915 ele concluiu que o governo não premuniu “os brasileiros do Nordeste contra os efeitos das secas". E arremata, nem

ao menos tratou de organizar um plano de socorro cuja base essencial seria impedir por todos os meios o deslocamento da população sertaneja em tempo de fome; a fixação delas em seus domicílios, dando-lhe trabalho e nunca esmolas. Se em algumas zonas fosse impossível fixar os habitantes, vindo eles ter a Fortaleza, não lhes dar passagem para fora do Estado, nem aglomerá-los em núcleos, abarracálos. ${ }^{112}$

Ora, o barão de Capanema não apenas elaborou um plano, mas um projeto que manteria os cearenses nos seus domicílios como atribuiu ao governo o papel de fomentar a modernização da agricultura e da pecuária, o que poderia ter re-inserido o Ceará e o Norte na economia agro-exportadora e com isso criado a base para um processo de acumulação endógena capaz de financiar a industrialização do Norte pari passu ao modo como se deu no Sul. Com isso, a

\footnotetext{
${ }^{111}$ AVELAR JR. Odilardo Viana de. A política de combate a seca no Nordeste: uma ideologia para o planejamento regional. Tese de Doutorado: Universidade de São Paulo, 1994, p.77.

${ }^{112}$ TEÓFILO, Rodolfo. A seca de 1915. Fortaleza-Ce, Edições UFC, 1980.
} 
industrialização do Nordeste não foi desigual como asseverou Celso Furtado, mas se deu de modo retardatário em relação ao Sul.

A razão fundamental para que Rodolfo Teófilo se opusesse ao projeto Capanema foi a mesma que levou Celso Furtado a idealizar a SUDENE - a incompreensão da seca como calamidade política. O resultado disso foi sempre a desestabilização da agricultura de exportação e subsistência, a desorganização burocrática dos municípios. A migração e o abandono dos domicílios no campo representaram perda de mão de obra e mercado interno necessários ao processo de industrialização. Observou Marcel Burstyn que

A política oficial no tocante às secas pode ser agrupada em duas categorias: as que são implantadas a posteriori, ou seja, como resposta à constatação de uma nova manifestação do fenômeno; e aquelas, mais recentes, que visam à criação de uma infra-estrutura que possa permitir a certas localidades resistir aos períodos de seca sem uma perda substancial de produtividade e de emprego, evitando, assim, as tensões sociais que caracterizam os momentos em que a falta de empregos coincide com a ausência de outras alternativas de sobrevivência no campo. ${ }^{113}$

Isso foi conseqüência, como já mostramos, da separação entre socorros públicos diretos e socorros públicos indiretos iniciado no Ceará com o PSEC (Plano de Socorros Públicos Diretos). Porém, até chegar a esse momento no início do século $\mathrm{XX}$ houve um incentivo a que os sertanejos pobres abandonassem os seus domicílios, tornarem-se retirantes, flagelados. Nesse sentido, tem razão Joaquim Nabuco quando diz que "Deve ser um estudo interessante o da História quando se pode seguir nele a linha de destino dos

\footnotetext{
${ }^{113}$ BURSTYN, Marcel. O Poder dos Donos: planejamento e Clientelismo no Nordeste. $2^{\mathrm{a}}$ Ed. Petrópolis, 1985, p.70.
} 
homens". 114

Nesse sentido, há várias semelhanças entre o projeto Pompeu Sinimbú (1878) e a proposta de desenvolvimento do Nordeste contida no relatório do GTDN (1958), como a noção de escassez dos recursos naturais, a separação entre agricultura e indústria, a preconização da ação do estado e a criação de organismos responsáveis pela condução da política de desenvolvimento. Francisco de Oliveira comentou acerca de Celso Furtado indagou:

Como é que Furtado ou Prebisch mentalizaram esse processo objetivo, não sabemos, e não vamos acreditar no psicologismo vulgar de que Furtado nasceu na Paraíba, portanto esteve sempre de cara e em contato com o subdesenvolvimento, como ele mesmo disso. ${ }^{115}$

Para não cairmos num psicologismo vulgar podemos alegar que Furtado nasceu num estado que se inseria historicamente nos limites traçados pelo projeto Pompeu Sinimbú, cuja herança era o estatismo, a noção de desigualdade regional e uma longa trajetória de criação de órgãos para lidar com o problema das secas. Não obstante Furtado se insere no processo de formação de uma identidade regional.

Nesse sentido, Eduardo Devés Valdés ao abordar o pensamento latino americano do século XIX ao século XX com a fundação da Cepal comparou a oscilação antagônica entre modernização e reforço da identidade cultural, mas com a fundação da Cepal teria havido uma proposta de "desarrollo". Segundo ele este "concepto englobante de uma propuesta de

${ }^{114}$ NABUCO, Joaquim. Diário (1877-1878). Vol. 1, Recife:Ed. Massangana / Bem - te-vi produções literárias, 2009, p.94.

115 OLIVEIRA, Francisco de. "Celso Furtado e o pensamento econômico brasileiro". In: MORAES, Reginaldo et al. Inteligência Brasileira. São Paulo: Brasiliense, 1986, p.157. 
crescimiento y modernización econômicos, com conexiones Em el âmbito sociocultural, vá a tener vastas repercursiones (y la practica) de época y, luego, durante todo lo que resta del siglo". ${ }^{116}$ No entanto, o projeto Cepalino no que tange ao Brasil resultou de um processo de modernização que fomentou uma identidade cultural - nordestinidade - maléfica do ponto de vista social porque estigmatizou a população e a região.

$$
* * *
$$

A vitória do projeto Pompeu Sinimbú sobre o projeto Capanema representou a vitória da idéia da seca como óbice ao progresso, da dependência ao governo central, do desestímulo a iniciativa particular, da fragilização da agricultura de subsistência e do estancamento do desenvolvimento econômico comprometido pela pequenez do mercado interno. A idéia da seca como óbice ao progresso econômico era coerente com o emprego, durante as secas, da prática assistencialista do socorro indireto. Com a dissociação deste do socorro direto em 1901 com a criação do PSEC e da SEOCS teve início processo de institucionalização do problema das secas que em sendo atualizado e no qual a SUDENE se insere historicamente representando uma continuidade e não uma ruptura.

\footnotetext{
${ }^{116}$ VALDÉS, Eduardo Devés. El pensamiento latinoamericano em el siglo XX. Entre la modernización y la identidad, tomo I, Del Ariel de Rodó a la CEPAL (1900-1905). $1^{\mathrm{a}}$ ed. Buenos Aires: Biblos, Centro de Investigaciones Diego Borges Arana, 2000, p.304.
} 


\section{Conclusão}

A violência no Ceará decorrente das lutas entre famílias se tornou uma questão política e administrativa após o regresso conservador em 1840. Por isso os presidentes da província enviados pelo governo central deram continuidade a um amplo conjunto de medidas que visavam restabelecer a segurança pública na região. Além de um problema político, a violência representava um entrave ao progresso material do Ceará. Entretanto, com a declaração da seca de 1877 ocorreu uma ruptura da política de combate à violência e a seca foi alçada à condição de calamidade política, o que desencadeou uma mudança do pensamento econômico da agroexportação para a manufatura.

Essa mudança significou na realidade a separação desses setores por meio de uma política de incentivos que apoiava um e negligenciava o outro. Assim, a disparidade material entre o Norte e o Sul que se verificou a partir de 1870 não surgiu com a perda do mercado agroexportador tradicional na primeira metade do século XIX, nem simplesmente com o deslocamento do eixo econômico para o Sul com a lavoura do café, mas resultou da implantação de uma política econômica equivocada centrada na atividade manufatureira.

A partir da conjuntura exposta pela seca de $1877-79$ se elaborou um projeto de desenvolvimento econômico para o Ceará, que se expandiu paulatinamente às províncias do Norte, que denominamos de projeto Pompeu Sinimbú. Esse projeto não partiu da perda da concorrência de produtos como o 
açúcar, o algodão e o tabaco, o que levaria a modernização da agricultura e da pecuária. Mas, ao revés tomou como paradigma a noção da seca como um obstáculo ao progresso da região, embora com a discordância de renomados cientistas como o geólogo barão de Capanema e o astrônomo Giácomo Gabaglia.

O projeto Pompeu Sinimbú, a despeito da oposição política e técnica que sofreu, consolidou-se como primeira fase de 1869 a 1898, através da instalação das comissões de socorros e obras públicas. Na seca de 1898 o presidente do Ceará Nogueira Acióli propôs a realização de obras públicas contras fora dos períodos de crise climática, proposta que representou uma evolução no projeto Pompeu Sinimbú.

Na seca de 1900 a proposta feita em 1898 se tornou exequíivel com o Plano de Socorros Estáveis e Completos (PSEC) implementado pela Superintendência de Estudos e Obras Contra as Secas (SEOCS) fundada em 1901. Com isso, ocorreu uma dissociação entre essas o socorro direto e o socorro indireto, sendo que este último se tornou bandeira política das elites cearenses. Porém, o resultado do projeto ao longo da sua primeira fase foi o fracasso do seu objetivo fundamental: a equiparação do Norte em relação ao Sul. Isso não se deu porque, como observou Celso Furtado, as obras encampadas não geraram capacidade produtiva, mas porque ocorreu o descolamento entre agroexportação e atividade manufatureira.

De fato as obras empreendidas açudes, pontes, estradas de ferro, cemitérios, igrejas e prédios públicos tinham como razão principal a assistência aos desvalidos, não desempenhando um papel significativo junto ao setor produtivo cada vez mais imobilizado pela falta de investimentos. Isso ocorreu 
porque a proposta do senador Pompeu teve o estatismo como projeto. No entanto, Celso Furtado na década de 60 do século XX ao compreender o desenvolvimento do Norte como desigual em relação ao Sul, não percebeu que essa desigualdade se formou de dentro para fora. Com isso, deve-se atribuir ao projeto Pompeu Sinimbú a raiz do subdesenvolvimento do Nordeste porque ele inviabilizou o processo de acumulação endógena como se deu com a produção cafeeira do Sul, tornando o orçamento público cearense constantemente deficitário e retardando a industrialização do Norte em relação ao Sul. No entanto Celso Furtado ao idealizar a SUDENE revigorou o estatismo como projeto.

Assim sendo, a conclusão final parece óbvia: o projeto Pompeu Sinimbú obliterou ao Ceará e as províncias do Norte o concurso da iniciativa particular, do empreendedorismo do empresário Schumpeteriano capaz de fomentar o progresso e o desenvolvimento. Nesse aspecto o Ceará teve o projeto do barão de Capanema, formulado inicialmente em 1861, que previa a participação do estado na modernização da agricultura e da pecuária, na adoção com relação às secas de medidas preventivas como o armazenamento de água, forragens e grãos nos anos de abundância para suprirem a população nos anos escassos. Além disso, o projeto Capanema defendeu uma política de incentivos do estado em relação aos agricultores e pecuaristas. 


\title{
Fontes
}

\author{
IMPRESSAS
}

Obra de referência

BUENO, Francisco da Silveira. Dicionário da Língua Portuguesa. São Paulo: Edições Fortaleza, 1972.

Revistas do Instituto Histórico e Geográfico do Ceará

GALENO, Juvenal. "Novas Canções Populares, a seca de 1878". Revista do Instituto do Ceará. Fortaleza: tipografia econômica, ano I, tomo I, primeiro trimestre de 1887, p.65-69.

PINTO, José Marcelo de Alcântara. Tomás Pompeu de Sousa Brasil: Um Senador do Império (Esboço biográfico). Revista do Instituto Histórico e Geográfico do Ceará. Ano CII-1988, p. 115.

PINTO, José Marcelo de Alcântara. Tomás Pompeu de Sousa Brasil: Um Senador do Império (Esboço biográfico). Revista do Instituto Histórico e Geográfico do Ceará. Ano CII- 1988, p. 117.

NOGUEIRA, Paulino. Execuções de Pena de Morte no Ceará. Revista do Instituto Histórico e Geográfico do Ceará. Ano VIII, 1894, p. 169.

NOGUEIRA, Paulino. Execuções de Pena de Morte no Ceará. Revista do Instituto Histórico e Geográfico do Ceará. Ano VIII, 1894, p.172.

NOGUEIRA, Paulino. Execuções de Pena de Morte no Ceará. Revista do Instituto Histórico e Geográfico do Ceará. Ano VIII, 1894, p. 175.

NOGUEIRA, Paulino. Execuções de Pena de Morte no Ceará. Revista do Instituto, 1894 , p. 325.

CESAR, Júlio. Registro de memória dos principais estabelecimentos. Revista do Instituto do Ceará. Ano I, 1887, p. 83-86.

FIRMEZA, Hermenegildo. A Revolução de 1912 no Ceará. Revista do Instituto do Ceará. Fortaleza, v.81, jan-dez, 1963, p.26.

MARTINS, Abílio. Versos Alegres. Revista do Instituto Histórico e Geográfico do Ceará. Ano LXIII, 1949, p. 237. 
FEIJÓ, João da Silva. Memória. Revista do Instituto do Ceará, ano III, 1889, p.327.

ABREU, Capistrano de. "Fases do Segundo Império". Revista do Instituto Histórico e Geográfico brasileiro. Rio de Janeiro, 1998, p.432-445.

\section{CORRESPONDENNCIA DO SENADOR POMPEU \\ (Organizada por José Aurélio Saraiva Câmara)}

Carta do Visconde de Sinimbú, Rio de Janeiro, 23 de dezembro de 1859.

Carta do Senador Saldanha Marinho, Rio de Janeiro, 23 de janeiro de 1863.

Carta do Senador Saldanha Marinho, Rio de Janeiro, 06 de julho de 1863.

Carta do Conselheiro Francisco Otaviano, Rio de Janeiro, 06 de junho de 1860.

Carta de Nogueira Acióli, Fortaleza, 22 de fevereiro de 1877.

> Carta de Nogueira Acióli, Fortaleza 10 de abril de 1877.

> Carta de Nogueira Acióli, Fortaleza 30 de abril de 1877.

$>$ Carta do Visconde de Sinimbú. Rio de Janeiro, 1 de outubro de 1877.

$>$ Carta do Visconde de Sinimbú, Rio de Janeiro, 23 de dezembro de 1859.

Carta do Visconde de Sinimbú. Rio de Janeiro, 1 de outubro de 1877.

\section{Produção Científica de Capanema e Raja Gabaglia}

GABAGLIA, Giácomo Raja. Ensaios sobre alguns melhoramentos tendentes à prosperidade da província do Ceará. Rio de Janeiro: Tipografia Nacional, 1877.

CAPANEMA, Guilherme. Apontamentos sobre as secas do Ceará. Rio de Janeiro: Tipografia Nacional, 1878.

CAPANEMA, Guilherme. A Seca do Norte. Rio de Janeiro: Imprensa Nacional, 1901. 
Correspondência do Barão de Capanema com o Imperador D. Pedro II

- Documentos do Barão de Capanema. Maço 129, Doc. 6344- [DO1-PO1]

- Resumo apresentado pelo Barão de Capanema ao Imperador Pedro II. 1860.

- Documentos do Barão de Capanema, maço 130, 6384, doc. 09.

- Capanema, maço 129 - doc 6344, do 2, po1.

- Capanema, maço 129 - doc 6344, do 2, po1

- Capanema, maço 129 - doc 6344,

- Documentos do Barão de Capanema Maço 130, Doc 6384, D01, P08. Ceará, 12 de abril de 1861.

- Documentos do Barão de Capanema maço 130, doc 6384, DO1, PO3.

- Documentos do Barão de Capanema maço 131, DOC 6452, D01, P03.

- Documentos do Barão de Capanema maço 131, DOC6452, D02, P01.

- Documentos do Barão de Capanema maço 131, doc 6452, do3, po3.

- Documentos do Barão de Capanema maço 131, 6452, do4, p01.

- Documentos do Barão de Capanema, maço 131, 6452, d04, p04.

- Documentos do Barão de Capanema, maço 131 - doc 6452, do6, p01

- Resumo apresentado pelo Barão de Capanema ao Imperador Pedro II. 1860.

- CAPANEMA, Barão de. Apontamentos sobre as secas do Ceará, p.18.

- Documentos do Barão de Capanema. Maço 200, Doc 9111, p.2.

- Documentos do Barão de Capanema. Maço 200, Doc 9111, p.2. 
KOSTER, Henry. Viagens ao Nordeste do Brasil. Cia Editora Nacional: São Paulo, 1942.

SPIX, J.B. von, MARTIUS, Carl Friedrich von. Viagem pelo Brasil. Imprensa Nacional: Rio de Janeiro, 1938.

AGASSIZ, Louis e Elisabeth C. Viagem ao Brasil. Cia. Editora Nacional: São Paulo, 1938.

GARDNER, George. Viagem ao interior do Brasil (1836 - 1841). Belo Horizonte, ed. Itatiaia, São Paulo: Editora da Universidade de São Paulo, 1975, p.84.

ALENCAR, José de. O sertanejo. 4ª, São Paulo: Melhoramentos, (s.d.), p. 346.

OLÍMPIO, Domingos. Luzia-Homem. $2^{\text {a }}$ ed. Rio de Janeiro: Livraria Castilho, 1929.

QUEIRÓS, Raquel de. Três Romances. Rio de Janeiro: Livraria José Olimpio Editora, 1957.

CAMPOS, Umberto de. Memórias Parte I. $7^{\mathrm{a}}$ ed. Livraria José Olimpio Editora, 1935.

\section{CD-ROM: REFUCIADOS DAS SECAS}

NOZOE, Nelson, BASSANEZI, Maria Silvia C. Beozzo Bassanezi, SAMARA Eni de Mesquita (orgs). Os refugiados das secas - São Paulo; NEHD, NEPO, CEDHAL, 2003.

\section{ARQUIVO PÚBLICO DO ESTADO DO CEARÁ/APEC.}

Relatórios, falas e mensagens dos Presidentes de Província e Estado de 1850 a 1901.

Relatório que por ocasião de deixar a presidência da província do Ceará, dirigiu Ignácio Francisco Silveira da Motta, ao seu sucessor Joaquim Marcos de Almeida Rego. Ceará: tipografia cearense, Rua da Boa vista nº. 33, 1851.

Relatório apresentado a Joaquim Vilela de Castro Tavares, presidente da província do Ceará, pelo seu antecessor Joaquim Marcos de Almeida Rego, ao passar-lhe a administração. Fortaleza: Tipografia Cearense 1853. 
Relatório com que Francisco Xavier Paes Barreto ao terceiro vice-presidente da mesma, Joaquim Mendes da Cruz Guimarães em 25 de março de 1857. Tipografia Cearense, 1857.

Fala com que o desembargador João Antonio de Araújo Freitas abriu a $1^{a}$ sessão da $18^{a}$ legislatura - Assembléia Provincial do Ceará - no dia $1^{\circ}$ de setembro de 1870. Fortaleza: Tipografia Constitucional, 1870.

Relatório com que Joaquim da Cunha Freire, $1^{\circ}$ vice-presidente da província do Ceará, passou a administração da mesma, no dia 13 de novembro de 1873, a Francisco Teixeira de Sá. Fortaleza, Tipografia constitucional, 1873.

Fala com que desembargador Francisco de Faria Lemos, presidente da província do Ceará abiu a $1^{\mathrm{a}}$ sessão da $23^{\mathrm{a}}$ legislatura da assembléia provincial de no dia $1 .^{\circ} 167$ de julho de 1878 - Fortaleza, tipografia cearense, 1876.

Relatório com que o doutor Francisco Xavier Paes Barreto ao terceiro vicepresidente da mesma Joaquim Mendes da Cruz Guimarães em 25 de março de 1857. Tipografia Cearense, 1857.

Relatório apresentado à Assembléia Legislativa Provincial do Ceará pelo desembargador João Antonio de Araújo Freitas Henriques, por ocasião da instalação da mesma Assembléia, no dia 1 de setembro de 1869.

Relatório com que por ocasião de deixar a presidência desta província dirigiu Ignácio Francisco Silveira da Mota ao seu. Tipografia Cearense, 1851, p.04-05.

Fala com que o presidente da província José Júlio de Albuquerque Barros abriu a 1 sessão da 24 legislatura, Fortaleza: Tipografia Brasileira, 1879.

Fala com que o presidente da província José Júlio de Albuquerque Barros abriu a 1 sessão da 24 legislatura, Fortaleza: Tipografia Brasileira, 1879.

Fala com que o presidente da província José Júlio de Albuquerque Barros abriu a 1 sessão da 24 legislatura, Fortaleza: Tipografia Brasileira, 1879.

Fala com que o presidente José Júlio de Albuquerque Barros, presidente da província do Ceará, abriu a 1 sessão da 25 legislatura, da Assembléia provincial, no dia 1 de julho de 1880. Fortaleza: tipografia brasileira, 1880.

Relatório apresentado ao presidente do Estado do Ceará coronel dr. José Freire Bezerril Fontenele pelo Secretário dos Negócios da Justiça coronel Valdemiro Moreira, junho de 1894. 
Mensagem apresentada à Assembléia Legislativa do Ceará pelo presidente do Estado Antonio Pinto Nogueira Acióli, em 1 de julho de 1900. Fortaleza: Tipografia da "A República", Rua Floriano Peixoto 55-A.

Relatório com que excelentíssimo o senhor conselheiro André Augusto de Pádua Fleury passou a administração da província do Ceará ao exmo. senhor., senador Pedro Leão Veloso no dia 1 de abril de 1881.

Fala com que excelentíssimo senhor Desembargador Caetano Estelita Cavalcante Pessoa Presidente da Província do Ceará abriu a $2^{\text {a }}$ Sessão da $23^{\text {a }}$ Legislatura da Respectiva Assembléia no dia 2 de julho de 1877.

Mensagem apresentada á Assembléia Legislativa do Ceará em $1^{\circ}$ de julho de 1901 pelo Presidente do Estado Dr. Pedro Augusto Borges, Fortaleza, 1901.

Mensagem apresentada a Assembléia Legislativa do Ceará em $1^{\circ}$ de julho de 1903, pelo presidente de Estado Dr. Pedro Augusto Borges, Ceará-Fortaleza, Tipografia Minerva, de Assis Bezerra.

Mensagem dirigida à Assembléia Legislativa do Ceará em 17 de julho de 1905 pelo presidente do estado Dr. Antonio Pinto Nogueira Acióli, Tipo-Litografia a vapor, 1905.

Mensagem dirigida á Assembléia Legislativa do Ceará em $1^{\circ}$ de julho de 1908.

Mensagem apresentada à Assembléia Legislativa do Ceará, em 1 de julho de 1901 pelo presidente do Estado Dr. Pedro Augusto Borges. Fortaleza: Tipografia Econômica, n. 43, Praça do Ferreira, 1901.

Fala com que o desembargador Caetano Estelita Cavalcante Pessoa presidente da província do Ceará abriu a 2 sessão da 23 legislatura, da respectiva assembléia, no dia 2 de julho de 1877, tipografia do Pedro II.

Relatório com que o Conselheiro João José Ferreira de Aguiar passou a administração da província do Ceará a Paulino Nogueira Borges da Fonseca, 3 vicepresidente da mesma província, no dia 22 de fevereiro de 1878.

Relatório com que o Conselheiro João José Ferreira de Aguiar passou a administração da província do Ceará a Paulino Nogueira Borges da Fonseca, 3 vicepresidente da mesma província, no dia 22 de fevereiro de 1878. 
Relatório com que o Senhor Conselheiro João José Ferreira de Aguiar passou a administração da província do Ceará a Paulino Nogueira Borges da Fonseca, 3 vicepresidente da mesma província, no dia 22 de fevereiro de 1878.

Fala com que José Júlio de Albuquerque Barros presidente da província do Ceará abriu a 1 sessão da 24 legislatura da Assembléia Provincial, no dia 1 de novembro de 1878. Fortaleza: Tipografia Brasileira, 1879.

Fala com que o exmo sr. Dr José Júlio de Albuquerque Barros presidente da província do Ceará, abriu a 1 sessão da 24 legislatura da Assembléia Provincial no dia 1 de novembro de 1878 de 1878.

Fala com que o presidente Caetano Estelita Cavalcante Pessoa Presidente da Província do Ceará abriu a 2 sessão da 23 legislatura, da respectiva Assembléia, no dia 02 de julho de 1877.

Mensagem do presidente do Estado do Ceará Coronel Dr. José Freire Bezerril Fontenele à respectiva Assembléia Legislativa em sua 5 Sessão Ordinária, da 1 legislatura. Fortaleza: Tipografia da República, 1896.

Fala com que o desembargador Caetano Estelita Cavalcanti Pessoa, abriu a 2 sessão da 23 legislatura, da respectiva Assembléia no dia 2 de julho de 1877. Fortaleza: Tipografia Pedro II.

Relatório com que o Conselheiro João José Ferreira de Aguiar passou a administração da província do Ceará ao Dr. Paulino Nogueira Borges da Fonseca, 3 vice-presidente da mesma província em 22 de fevereiro de 1878.

Relatório apresentado ao segundo vice-presidente da província do Ceará Gonçalo Batista Vieira pelo primeiro vice-presidente Antonio Joaquim Rodrigues Junior no ato de passar-lhe a administração da mesma província. Fortaleza: Tipografia Brasileira, 31 de julho de 1868.

Relatório apresentado ao segundo vice-presidente da província do Ceará Gonçalo Batista Vieira pelo primeiro vice-presidente Antonio Joaquim Rodrigues Junior no ato de passar-lhe a administração da mesma província. Fortaleza: Tipografia Brasileira, 31 de julho de 1868.

Mensagem apresentada à Assembléia Legislativa do Ceará pelo presidente do Estado Pedro Augusto Borges. Fortaleza: Tipografia Econômica: 1 de julho de 1901.

Relatório com que o Conselheiro Henrique D’Ávila, senador do Império e presidente do Ceará passou a administração da província ao exmo sr. Fortaleza: Tipografia Econômica, 1889. 
Mensagem dirigida à Assembléia Legislativa do Ceará em $1^{\circ}$ de Julho de 1907, pelo presidente do Estado Antonio Pinto Nogueira Acióli.

Comissão de Socorros Públicos. Ministério do Interior, 188:8: Folhetim Serviço da Seca, 1889.

Relatório com que excelentíssimo senhor Conselheiro Henrique D Ávila, senador do Império e Presidente do Ceará, passou a administração desta ao excelentíssimo senhor (?). Fortaleza, Tipografia Econômica, 1889.

Mensagem apresentada a Assembléia Legislativa do Ceará pelo presidente do Estado Antonio Pinto Nogueira Acióli em 4 de julho de 1898. Fortaleza: Tipografia Econômica, 1898.

Mensagem apresentada à Assembléia Legislativa do Ceará em 1 de julho de 1901 pelo presidente do Estado Pedro Augusto Borges. Fortaleza: Tipografia Econômica, 1901.

Mensagem dirigida à Assembléia Legislativa do Ceará em 1 de julho de 1905, p.45.

Mensagem dirigida à Assembléia Legislativa do Ceará, pelo presidente do Estado Antonio Pinto Nogueira Acióli. Fortaleza: Tipolitografia a Vapor, em 1 de julho de 1910.

Relatório com que o Exmo Sr. Conselheiro João José Ferreira de Aguiar passou a administração da província do Ceará ao Exmo sr. Dr. Paulino Nogueira Borges da Fonseca, 3 vice-presidente da mesma província em 22 de fevereiro de 1878. Fortaleza: tipografia brasileira.

Livro de Registro de Ofícios a diversos. 1870, fl 113, Arquivo do Arcebispado de Fortaleza.

Revista do Instituto Histórico e Geográfico do Ceará. R. Gomes de Mattos. Notas sobre o Município de Quixadá, 1892.

Relatório com que o exm. Sr. Conselheiro João José Ferreira de Aguiar passou a administração da província do Ceará ao Exmo Sr. Dr. Paulino Nogueira Borges da Fonseca, $3^{\circ}$ vice-presidente da mesma província, em o dia 22 de fevereiro de 1878.

Relatório com que o exm. Sr. Conselheiro João José Ferreira de Aguiar passou a administração da província do Ceará ao Exmo Sr. Dr. Paulino Nogueira Borges da Fonseca, $3^{\circ}$ vice-presidente da mesma província, em o dia 22 de fevereiro de 1878.

Paço da Câmara Municipal da Vila de Jaguaribe Mirim, em 20 de março de 1878. 
Paço da Câmara Municipal da Vila de Jaguaribe - Mirim, em sessão ordinária de 6 de outubro de 1877.

Paço da Câmara Municipal da Vila de Jaguaribe Mirim, sessão ordinária de 6 de outubro de 1877.

Anais da Assembléia Legislativa do Ceará. (organizados pelos taquígrafos Lourenço B. Cavalcante e Carlos P.), Fortaleza - Ceará, 1910, p.20.

\section{DOCUMENTOS DAS CÂMARAS MUNICIPAIS}

Paço da Câmara Municipal de Jaguaribe - Mirim, em sessão extraordinária de 31 de agosto de 1881.

Projeto de Posturas apresentando à Câmara Municipal de Fortaleza, N. .681 em sessão de 11 de novembro de $1881, \mathrm{n}^{\circ} .32$.

Livro Matrícula de Criados, nº.71, 1887.

Código de Posturas da Câmara Municipal de Fortaleza, 1916.

Comissão de Transportes por Mar, Fortaleza, 12 de dezembro de 1879.

\section{MANUSCRITAS}

\section{COMISSÕES DE SOCORROS OBRAS PÚBLICAS DO CEARÁ}

Governo do Ceará. Grupo: Comissões de Socorros Públicos. Série: Ofícios expedidos. Data: 1888-1889. Fortaleza. Ala: 19, estante: 400, caixa 13.

Governo da Província do Ceará. Grupo: Comissão de Socorros Públicos. Série: ofícios expedidos, sub-série: seca. (1877-1880). Ala 19, estante 40, caixa 14.

Governo da Província do Ceará. Grupo: Comissão de Socorros Públicos. Série: ofícios expedidos, sub-série: seca. (1877-1880). Ala 19, estante 40, caixa 14.

Governo da Província do Ceará. Grupo: Comissão de Socorros Públicos. Série: ofícios expedidos, sub-série: seca. (1877-1880). Ala 19, estante 40, caixa 14.

Governo da Província do Ceará. Grupo Comissão de Socorros Públicos. Ofícios expedidos, sub-série: seca, 1877-1880. Ala 19, estante 40, caixa 15. 
Governo da Província do Ceará. Grupo Comissão de Socorros Públicos. Ofícios expedidos, sub-série: seca, 1877-1880. Ala 19, estante 40, caixa 15. Relação das famílias alistadas no $5^{\circ}$ distrito do Alto da Pimenta com o respectivo pessoal.

Governo da Província do Ceará. Grupo Comissão de Socorros Públicos. Ofícios expedidos, sub-série: seca (1877-1880). Ala 19, estante 40, caixa 15. Relação das famílias alistadas no $8^{\circ}$ distrito, 12 de julho de 1879 .

Comissão de socorros públicos da cidade de Santana, 26 de outubro de 1877.

Comissão de socorros públicos da cidade de Santana, 26 de outubro de 1877.

Comissão de Socorros de São João do Príncipe, 11 de julho de 1877.

Carta ao Palácio do Governo do Ceará remetida por João Francisco Junior, 23 de outubro de 1877.

Comissão de socorros púbicos da vila de Quixadá, 8 de junho de 1877.

Comissão de Socorros Públicos do Ceará, 11 de setembro de 1877.

Povoação de São Gonçalo, 15 de outubro de 1877.

Comissão de Socorros de São João do Príncipe, 16 de setembro de 1877.

Comissão de Socorros de São João do Príncipe, 16 de Setembro de 1877.

Governo do Ceará. Grupo: Comissões de Socorros Públicos. Série: Ofícios expedidos. Data: 1888-1889. Fortaleza. Ala: 19, estante: 400, caixa 13.

Governo da Província do Ceará. Grupo: Comissão de Socorros Públicos. Série: ofícios expedidos, sub-série: seca. (1877-1880). Ala 19, estante 40, caixa 14.

Governo da Província do Ceará. Grupo: Comissão de Socorros Públicos. Série: ofícios expedidos, sub-série: seca. (1877-1880). Ala 19, estante 40, caixa 14.

Governo da Província do Ceará. Grupo: Comissão de Socorros Públicos. Série: ofícios expedidos, sub-série: seca. (1877-1880). Ala 19, estante 40, caixa 14.

Governo da Província do Ceará. Grupo Comissão de Socorros Públicos. Ofícios expedidos, sub-série: seca, 1877-1880. Ala 19, estante 40, caixa 15.

Governo da Província do Ceará. Grupo Comissão de Socorros Públicos. Ofícios expedidos, sub-série: seca, 1877-1880. Ala 19, estante 40, caixa 15. Relação das famílias alistadas no $5^{\circ}$ distrito do Alto da Pimenta com o respectivo pessoal. 
Governo da Província do Ceará. Grupo Comissão de Socorros Públicos. Ofícios expedidos, sub-série: seca (1877-1880). Ala 19, estante 40, caixa 15. Relação das famílias alistadas no $8^{\circ}$ distrito, 12 de julho de 1879.

Comissão de socorros públicos da cidade de Santana, 26 de outubro de 1877.

Comissão de socorros públicos da cidade de Santana, 26 de outubro de 1877.

Comissão de Socorros de São João do Príncipe, 11 de julho de 1877.

Carta ao Palácio do Governo do Ceará remetida por João Francisco Junior, 23 de outubro de 1877.

Comissão de socorros púbicos da vila de Quixadá, 8 de junho de 1877.

Comissão de Socorros Públicos do Ceará, 11 de setembro de 1877.

Povoação de São Gonçalo, 15 de outubro de 1877.

Comissão de Socorros de São João do Príncipe, 16 de setembro de 1877.

Comissão de Socorros de São João do Príncipe, 16 de Setembro de 1877

Abarracamento do 12 distrito a cargo de Adolfo Herbster, Fortaleza, 20 de junho de 1879.

Governo da Província do Ceará. Grupo Comissão de Socorros Públicos. Ofícios expedidos, subsérie: seca, 1877-1880. Ala 19, estante: 40, caixa 15.

Governo da Província do Ceará, comissão de socorros públicos, ofícios expedidos, subsérie seca (1877-1880). Ala 19, estante 40, caixa 15.

Governo da Província do Ceará, comissão de socorros públicos, ofícios expedidos, subsérie seca (1877-1880). Ala 19, estante 40, caixa 15.

Governo da província do Ceará. Comissão de Socorros Públicos. Série: ofícios expedidos, Comissão de Socorros de Santa Quitéria, 15 de abril de 1879. Ala: 19, caixa: 22 , estante: 400 .

Comissão de Socorros da Vila de Quixadá, 31 de março de 1879.

Comissão de Socorros de Itaperi, 24 de fevereiro de 1879.

Comissão de Socorros de Itaperi, 10 de janeiro de 1789.

Comissão de Socorros de Várzea Alegre, 20 de julho de 1879. 
Secretaria do governo, 20 de dezembro de 1879.

Carta do administrador da Capela de Siupé, 1 de março de 1878.

Governo da Província do Ceará. Comissão de Socorros Públicos, Fortaleza, 1879, ala: 19 , estante: 400 , caixa: 10 .

Comissão de Socorros Públicos de Palma, 1877-78.

Comissão de socorros de São Gonçalo, 21 de novembro de 1877.

Comissão de Socorros Públicos $6^{\circ}$ Distrito da Fortaleza, 2 de julho de 1879.

Comissão de Socorros Públicos $6^{\circ}$ Distrito da Fortaleza, 2 de julho de 1879.

Comissão de Socorros Públicos $6^{\circ}$ Distrito da Fortaleza, 2 de julho de 1879.

Comissão de Socorros Públicos de Gado dos Ferros, 15 de março de 1879. Relação dos indigentes socorridos por esta comissão.

Comissão de Socorros da Vila de Quixadá, 2 de novembro de 1877.

Comissão de Socorros da Vila de São Benedito, 07 de novembro de 1878.

Comissão de melhoramentos de Estradas e Ladeiras em Baturité, 8 de Maio de 1889.

Comissão de melhoramentos de Estradas e Ladeiras em Baturité, 8 de Maio de 1889.

Comissão de melhoramentos de Estradas e Ladeiras em Baturité, 8 de Maio de 1889.

Comissão de melhoramentos de Estradas e Ladeiras em Baturité, 8 de Maio de 1889.

Comissão de melhoramentos de Estradas e Ladeiras em Baturité, 8 de Maio de 1889.

Comissão de melhoramentos de Estradas e Ladeiras em Baturité, 8 de Maio de 1889.

Fundo: Governo da Província do Ceará. Grupo: Comissão de Socorros Públicos. Série: Ofícios expedidos, subsérie: seca (1877-1880). Ala: 19, estante: 400, caixa: 15 .

Comissão de Socorros Públicos, Pajussara, 2 de março de 1889.

Obras do açude do Acarape, 16 de maio de 1889. 
Obras provinciais, serviço da seca. Fortaleza, 18 de junho de 1889.

Obras provinciais, serviço da seca Fortaleza, 18 de junho de 1889.

Obras provinciais, serviço da seca, Açude do Acarape. Fortaleza, 10 de junho de 1889.

Serviço da seca. Obras Provinciais a cargo do engenheiro Antonio Lassance Cunha, Fortaleza, 10 de junho de 1889.

Serviço da seca. Obras Provinciais a cargo do engenheiro Ernesto Antonio Lassance Cunha, Fortaleza, 29 de agosto de 1889.

Comissão de Socorros Públicos de São João do Príncipe, 19 de novembro de 1877.

Comissão de Socorros Públicos de São João do Príncipe, 14 de novembro de 1877.

Comissão de melhoramentos de Estradas e Ladeiras em Baturité, 8 de Maio de 1889.

Diretoria da Comissão de Obras Públicas da Vila de Tamboril, 6 de agosto de 1889. Comissão de Socorros Públicos da Vila de Tamboril, 26 de agosto de 1889.

Governo do Ceará. Grupo: Comissões de Socorros Públicos. Série: Ofícios expedidos. Data: 1888-1889. Fortaleza. Ala: 19, estante: 400, caixa 13.

\section{CENSOS POPULACIONAIS}

CEDHAL -Projeto. NOZOE, Nelson, BASSANEZI, Maria Silvia C. Beozzo Bassanezi, SAMARA Eni de Mesquita (orgs). Os refugiados das secas - São Paulo; NEHD, NEPO, CEDHAL, 2003.Estatísticas Históricas para o Estudo da População no passado: acervo do Arquivo Público Estadual do Ceará apoiado pela FAPESP (Fundação de Amparo à Pesquisa do Estado de São Paulo), em 1987-88. CD Rom: transcrição das 5.860 portarias concedendo saída para 32 mil pessoas atingidas pela última seca do Império (1888-1889).

CEDHAL - Banco de Dados. Arrolamentos da Freguesia de São José da Cidade de Fortaleza. Empreendido pelo chefe de Polícia da Província Dr. Araújo Torreão em 
1887. Fundo: Secretaria de Polícia. Ala: Estante: Livro(s) nos 382, 383, 384, 385, 444 .

Arrolamentos da Freguesia de São José da cidade de Fortaleza. Empreendido pelo chefe de polícia da província Dr. Araújo Torreão em 1877. Fundo: Secretaria de Polícia. Livros 382, 383, 384, 385, 444. 


\section{Bibliografia}

ABREU, M. de P., 'A dívida pública externa do Brasil, 1931-1943', Pesquisa e Planejamento Econômico, 5 (1), 1975.

Econômicos, 15 (2), 1985.

. “A dívida pública externa do Brasil, 1824-1931”, Estudos

ALEGRE, Sylvia Porto. "Fome de Braços, Questão Nacional: notas sobre o trabalho livre no Nordeste do século XIX. In: Revista de Ciências Sociais. Fortaleza, UFC; v.16/17, n.1/2, 1985/1986.

ALVES, Joaquim. História das Secas: séc. XIX e XX. Ed. Fac-similar. Fortaleza: Fundação Waldemar Alcântara, 2003.

ANDERSON, Michael. Elementos para a história da família ocidental (1500-1914). Lisboa: Editorial Querco, 1984.

ARAGÃO, R. Batista. Cronologia dos Municípios Cearenses. Fortaleza: Barraca do Escritor Cearense, 1996.

ARIÉS, Philippe. História Social da Criança e da Família. Rio de Janeiro: Zahar Editores, 1978.

ALBUQUERQUE JR, Durval Muniz de. A Invenção do Nordeste: e outras artes. São Paulo: Cortez, 1999.

ALBUQUERQUE JR., Durval Muniz de. Preconceito contra a origem geográfica e de lugar: as fronteiras da discórdia. São Paulo: Cortez, 2007, p.92.

ALMEIDA, Angela Mendes de (org.). Pensando a família no Brasil: da colônia à modernidade. Rio de Janeiro: Espaço e Tempo: UFRRJ, 1987.

ALENCAR, Edigar de. Fortaleza de Ontem e Ante-Ontem. Fortaleza, Edições UFC, 1980.

ALBUQUERQUE, Mozart Soriano. História Abreviada de Fortaleza. Fortaleza, Edições UFC, 1982.

ANSELMO, Otacílio. Padre Cícero, mito e realidade. Rio de Janeiro, Civilização Brasileira, 1968. 
ARAGÃO, Elizabeth Fiúza. A Transformação na Indústria Têxtil no Ceará: O Setor de Fiação e Tecelagem (1880-1950). Fortaleza, Ed. UFC/Stylus Comunicações, 1989.

AZEVEDO, Sânzio de. Adolfo Caminha (vida e obra). Fortaleza: Casa José de Alencar/ Programa Editorial, 1997.

. A Padaria Espiritual e o simbolismo no Ceará. Fortaleza, Casa de José de Alencar/UFC, 1996.

BARROS, R.P., Mendonça, R.S.P. 1997. "Bem-estar, pobreza e desigualdade de renda: uma avaliação da evolução histórica e das disparidades regionais." Texto para discussão, 454, IPEA.

BARBOSA, José Policarpo. História da Saúde Pública no Ceará. Fortaleza, EUFC, 1994.

BARREIRA. Dolor. História da Literatura Cearense. Fortaleza: Instituto do Ceará, 4v.,1948, 1951,1954 e 1962.

BARROSO, Gustavo. Memórias de Gustavo Barroso. 2. Ed. Fortaleza: Governo do Estado do Ceará, 1989 (Edição em conjunto das obras: Coração de Menino, Liceu do Ceará e Consulado da China).

A Margem da História do Ceará. Fortaleza: Imprensa Universitária do Ceará, 1962.

. Mississipi. Rio de Janeiro: Edições o Cruzeiro, 1961.

BARROS, Luitgarde Oliveira Cavalcanti. A terra da mãe de Deus. Brasília, Francisco Alves/INL, 1988.

BRAZIL, Thomaz Pompeu de. O Ceará no Centenário da Independência. Fortaleza, Tip. Minerva, 1922.

Rápida Notícia sobre o Ceará destinada à Exposição de Chicago. Fortaleza, s/ed., 1893.

BARBOSA, Ivone Cordeiro. Sertão: um lugar incomum. O sertão do Ceará na literatura do século XIX. Rio de Janeiro, Relume Dumará; Fortaleza-Ce: Secretaria de Cultura e Desporto do Estado, 2000.

BARCELLAR, Carlos de Almeida Prado. Famillia, herança e poder em São Paulo: 1765-1855. São Paulo: Tese de doutorado, USP, 1991. 
BASSANEZI, Maria Silvia C. Beozzo. Migrantes no Brasil da segunda metade do século XIX. In: ANAIS do XII Encontro da Associação Brasileira de Estudos Populacionais - ABEP, 2000. Caxambu/MG, 23 a 27 de outubro de 2000.

BRANDÃO, Moreno. Visconde de Sinimbú: traços biográficos. Maceió: Livraria Americana, 1914.

BRAUDEL, Fernand. "História e Ciências Sociais. A longa duração". Escritos Sobre a História. $2^{a}$ ed. São Paulo: Perspectiva, 1992.

BRAGA, Renato. História da Comissão Científica de Exploração. Fortaleza: Imprensa Universitária do Ceará, 1962.

BRASIL, Thomaz Pompeo de Sousa. Ensaio Estatístico da Província do Ceará. ed. fac. sim, Fortaleza: Fundação Waldemar Alcântara, 1997.

BRÍGIDO, João. O Ceará (Lado Cômico). Fortaleza, s/ed., 1900.

BRITO, F. Saturnini Rodrigues de. Saneamento de Fortaleza. Fortaleza, Oficinas do Diário do Estado, 1923.

CASEY, James . História da Família. Lisboa, Teorema, 1989.

CHAVES, Olivenor Souza. Fortaleza e os Retirantes da Seca de 1877-79. Recife: mimeo, 1995.

COSTA PINTO, Luís de Aguiar. Lutas de famílias no Brasil (Introdução ao seu estudo). São Paulo/ Brasília, Cia Ed. Nacional/INL, 1980.

CARVALHO, Jader de. Antologia de João Brígido. Fortaleza: Editora Terra de Sol, 1968 , p. 520.

CASTORIDIS, Cornélius. A Instituição Imaginária da Sociedade, 5aed. Ed. Paz e Terra: 1982 .

CAMARA, João. Almanaque Administrativo, Estatístico, Mercantil, Industrial e Literário do Ceará. Fortaleza, Tip. d'A República(Coleção Completa de 1895 a 1930).

CAMPOS, Eduardo. Capitulos de história da Fortaleza do século XIX. Fortaleza, Edições UFC, 1985.

CANDIDO, Tyrone Apollo Pontes. Trem da seca: sertanejos, retirantes e operários (1877-1880). Fortaleza: Museu do Ceará; Secretaria da Cultura do Estado do Ceará, 2005.

CARVALHO, Jáder de. Antologia de João Brígido. Fortaleza, Terra e Sol, 1969. 
CARVALHO, José Murilo de. D. Pedro II. São Paulo: Companhia das Letras, 2007.

CARVALHO, José Murilo de. A Construção da Ordem: a elite política imperial. Teatro de Sombras: a política imperial. Rio de Janeiro: Civilização Brasileira, 2003, p.113.

COLARES, Otacílio. Crônicas de Fortaleza e do Siará Grande. Fortaleza, Edições UFC, 1980.

CARVALHO, Ricardo Ismael. Nordeste: a força da diferença - os impasses e desafios na cooperação regional. Recife: Editora Massangana, 2005.

CARVALHO, Jader de. Antologia de João Brígido. Fortaleza-ce: Editora Terra de Sol, 1969, p.561-596.

DINIZ, Clélio Campolina. A questão Regional e as Políticas Governamentais no Brasil. In: SZMRECSÁNYI, Tamás, COELHO, Francisco da Silva. (orgs.) Ensaio de História do Pensamento Econômico no Brasil Contemporâneo. São Paulo: Atlas, 2007.

EISENBERG, P. L. Homens esquecidos: escravos e trabalhadores livres no Brasil, séculos XVIII e XIX. Campinas: Editora da UNICAMP, 1989.

FEIJÓ, João José da Silva. Memória sobre a capitania do Ceará e outros trabalhos. Ed. Fac-similar, 1997.

FOHLEN, Claude. O faroeste (1860-1890). São Paulo: Companhia das Letras: Círculo do Livro, 1989.

FREYRE, Gilberto. Nordeste. 6ª ed. Rio de Janeiro: Record, 1989.

FROTA, D. José Tupinambá da Frota. História de Sobral. 2a ed. Fortaleza-Ceará: Editora Henriqueta Galeno, 1974.

FRANCO, Maria Sylvia de Carvalho. Os homens livres na ordem escravocrata. São Paulo, Ática, 1974.

FURTADO, Celso. Teoria e Politica do Desenvolvimento Econômico. $2^{\mathrm{a}}$ ed. São Paulo: Nova Cultural, 1986. . A Fantasia Desfeita. Rio de Janeiro: Paz e Terra, 1989.

1983. . Não à recessão e ao desemprego. Rio de Janeiro: Paz e Terra, 
GONÇALVES, Paulo César. Migração e Mão de Obra. Retirantes Cearense na Economia Cafeeira do Centro Sul (1877-1901). Dissertação de Mestrado: USP, São Paulo, 2002.

GIRÃO, Raimundo e MARTINS Filho Antônio. O Ceará. Fortaleza, Ed. Fortaleza, 1939.

. Fortaleza e a Crônica Histórica. Fortaleza. Fortaleza, Edições UFC, 1984.

. Geografia Estética de Fortaleza. Fortaleza, BNB, 1985.

. Pequena História do Ceará. Fortaleza, Edições UFC, 1983.

. História Econômica do Ceará. Monografia no. 22, Editora "Instituto do Ceará”, 1947.

GRAHAM, Richard. Clientelismo e política no Brasil do século XIX. Rio de Janeiro: Editora UFRJ, 1997.

HOBSBAWN, Eric. "Historiadores e Economia II". In: Sobre a História. São Paulo, Cia Das Letras, 2000.

LEWIN, Linda. Política e Parentela na Paraíba. Rio de Janeiro: Record, 1993, p.113.

LASLETT, Peter. Household and family in past time. London: Cambridge University Press, 1972.

MATTOS, Ilmar R. O tempo de Saquarema. A formação do estado Imperial. São Paulo: Hucitec, 1990.

MATOS, Maria Izilda Santos. Cotidiano e Cultura: história, cidade e trabalho. Bauru, SP: EDUCS, 2002.

Trama e Poder: trajetória e poder em torno da industria de sacaria para o café (São Paulo, 1888-1934). 2a ed. Rio de Janeiro: Sette Letras, 1996

MORAIS, Viviane Lima de. As Razões e Destinos da Migração: trabalhadores e emigrantes cearenses pelo Brasil no final do século XIX. Dissertação de Mestrado, PUC/SP, 2003.

MENEZES, Raimundo de. Coisas que o tempo levou.(Crônicas Históricas de Fortaleza Antiga). Fortaleza: Edésio, 1938.

MELLO, Evaldo Cabral de. O Norte Agrário e o Império: 1871-1889. Rio de Janeiro: Nova Fronteira; Brasília: INL, 1984.

MELLO, João Cabral de. Um imenso Portugal: história e historiografia. São Paulo: Ed. 34, 2002, p.15. 
MOTA, Aroldo. História Política do Ceará. Fortaleza, Stylus, 1987. Olympio, 1982.

MOTTA, Felipe Ronner Pinheiro Imlau. Progresso, Calamidade e Trabalho: confrontos entre cidade e Sertão em Fins dos Oitocentos (Fortaleza/ 1850 -1888). Dissertação de Mestrado, PUC/SP, 2003.

MORAIS, Viviane Lima de. Razões e Destinos da Migração. Trabalhadores e Emigrantes Cearenses pelo Brasil no final do século XIX. Mestrado em História Social, PUC, São Paulo, 2003, p.140.

MENEZES, Antonio Bezerra de. O Ceará e os cearenses. Ed. Fac-sim. - Fortaleza: Fundação Waldemar Alcântara, 2001.

MONTENEGRO, João Alfredo de SOUZA. Integralismo e Catolicismo. In: Simone. História do Ceará. 4e. Fortaleza: Fundação Demócrito Rocha, 1995.

NABUCO, Joaquim. Diários (1873-1878). Vol. 1. Recife: Ed. Massangana / Bem-tevi produções literárias, 2005, p.94.

NOGUEIRA, João. Fortaleza Velha. Fortaleza, Edições UFC, 1984.

NETO SOUSA, Manoel Fernandes de. Senador Pompeu: um geógrafo do Império Brasil. São Paulo: Dissertação de Mestrado, USP, 1997.

NEVES, Frederico de Castro. A multidão e a história: saques e outras ações de massas no Norte do Brasil. Rio de Janeiro: Relume Dumará: Fortaleza-ce: Secretararia de Cultura e Desporto, 2000.

. (org.) Nordeste: Identidade, Imagem e literatura. Fortaleza: UFC/NUDOC (cadernos do NUDOC, Série História, n 17) 1996.

NOZOE, Nelson. Bassanezi, Maria S. C. Beozzo. (orgs) Os refugiados da Seca: emigrantes cearenses (1888-1889). São Paulo; Campinas: NEHD, NEPO, CEDHAL, 2003.

NOBRE, Geraldo. Introdução à História do Jornalismo Cearense. Fortaleza: Gráfica Editorial Cearense, 1974, p.14.

OLIVEIRA, Francisco de. "Celso Furtado e o pensamento econômico brasileiro". In: MORAES, Reginaldo et al. Inteligência Brasileira. São Paulo: Brasiliense, 1986.

OLIVEIRA, André Frota de. A Estrada de Ferro de Sobral. Fortaleza: Expressão Gráfica e Editora Ltda, 1994, p.35. 
PINTO, Virgílio Noya. Balanço das transformações econômicas no século XIX. In MOTA, Carlos Guilherme (org.). Brasil em Perspectiva. $15^{\text {a }}$ ed. São Paulo: DIFEL, 1985, p.134.

PONTE, Sebastião Rogério. Fortaleza Belle Epóque. Fortaleza, Fundação Demócrito Rocha, 1994.

PRADO, Danda. O que é família. 2a ed. São Paulo: brasilense, 1982.

PRADO JÚNIOR, Caio. "História quantitativa e o método da historiografia". Debate e Crítica. São Paulo, n.6., jul.,1975, p.1-19.

PINTO, Luis de Aguiar Costa. Lutas de Famílias no Brasil. 2a ed. São Paulo: Ed. Nacional; INL, 1980.

PENNA, Maura. O que faz ser nordestino: identidades sociais, interesses e o "escândalo" Erundina. São Paulo: Cortez, 1992.

SANDRONI, Paulo. Dicionário de Economia do século XXI. $4^{\mathrm{a}}$ ed. Rio de Janeiro: Record, 2008.

SARTI, Cynthia Andersen. A familia como espelho: um estudo sobre a moral dos pobres. $2^{\mathrm{a}}$ ed. São Paulo: Cortez, 20003.

SAMARA, Eni de Mesquita. As mulheres, o poder e a família: São Paulo, século XIX. São Paulo: Editora Marco Zero e Secretaria do Estado da Cultura de São Paulo, 1989.

Historiografia Brasileira em Debate: olhares, recortes e tendência. São Paulo: Humanitas/ FFLCH/USP, 2002.

- Paleografia e Fontes do período colonial brasileiro. São Paulo: Humanitas/FFLCH/USP, 1986.

.Família Brasileira. $3^{\text {a }}$ ed. São Paulo: Brasiliense, 1986.

e LOPES, Eliane Cristina. Família, mulheres e prostituição no Nordeste do Brasil. Fortaleza, Século XIX. In: CICERCHIA, Ricardo (org.). Formas Familiares, procesos históricos y cambio en América Latina. Quito (Equador): Ediciones Ayala, 1998.

SAMARA, Eni de Mesquita, SOUSA, José Weyne de Freitas. "Morar e Viver no Nordeste do Brasil: Fortaleza, século XIX”. In: LÓPEZ, Rosalva Loreto (cord.). Perfiles Habitacionales y ambientales: historia urbana de Latinoamérica, siglos XVII-XIX. Puebla: Benemérita Universidade Autônoma de Puebla, 2007. 
SOUSA, José Bonifácio de. Quixadá: de fazenda a cidade (1775 - 1955). Rio de Janeiro, DF: Serviço Gráfico do IBGE, 1960.

. Para a História do Jornalismo Cearense (1890-1924). Fortaleza, Tip. do Instituto do Ceará, 1925.

QUEIRÓS, Rachel de. O Quinze. 54 ed. São Paulo: Siciliano, 1993.

RIBEIRO,Valdir Uchoa. Brasil-República: os presidentes. Fortaleza: Premius Editora, 2001.

STUDART, Barão de. Climatologia, Epidemias e Endemias no Ceará. Ed. Facsimilar, 1997.

STUDART, Guilherme. Patologia Histórica Brasileira: documentos para a história da pestilência da bicha ou males, ed. Fac-similar, 1997.

STUDART, Barão de. Datas e Factos para a História do Ceará. Ed. fac. sim. , Fortaleza: Fundação Waldemar Alcântara, 2001, p.274.

SALES, Antônio. O Babaquara. Rio de Janeiro, Ed. do Autor. 1912.

SHWARTZ, Liliam Moritz. As barbas do Imperador. São Paulo: Companhia das Letras, 1998.

SZMRECSÁNYI, Tamás, LAPA, José Roberto Amaral (orgs.). História Econômica da Independência e do Império. $2^{\mathrm{a}}$ ed. Revista - São Paulo: HUCITEC/ Universidade de São Paulo/ Imprensa Oficial, 2002, p.209.

SHWARTZ, Stuart. Escravos, roceiros e rebeldes. Bauru, São Paulo: EDUSC, 2001, p.126.

SILVA, Jeovah Lucas. As bênçãos de Deus: seca como elemento educador para o trabalho (1877-1880). Dissertação de Mestrado - Universidade Federal do Ceará, Fortaleza, 2003.

SILVA, Régia Agostinho da. Entre Mulheres, História e Literatura: um estudo do imaginário em Emília de Freitas e Francisca Clotilde. Dissertação de Mestrado, UFC/Ce, 2002.

SINGER, Paul. Aprender Economia. 24å ed. São Paulo:Contexto, 2006.

SOARES, Martim. O Babaquara. Subsidios para a História da Oligarquia no Ceará. Rio, s/ ed., 1954. 
SOUZA, Simone (org.). História do Ceará. Fundação Demócrito Rocha, Fortaleza, 1995.

SOUZA, José Bonifácio. Formação Histórica do Comércio Cearense. Fortaleza, s/ed., 1954.

José Weyne de Freitas. Artífices, Criadas e Chicos: as experiências urbanas das crianças órfãs e pobres em Fortaleza de 1877-1915. Dissertação de Mestrado, PUC-SP, 2004.

José Weyne de Freitas. A família cearense: da criminalidade à seca como questão social (1850-1915). Revista População e Família. São Paulo, n.6, Humanitas, n.6, 2004, p.81-100.

José Weyne de Freitas Sousa e SAMARA, Eni de Mesquita. "Morar e Viver no Nordeste do Brasil”. Revista Trajetos. UFC, 2006.

SOUSA, Octávio Tarquínio de Sousa. José Bonifácio. Rio de Janeiro: Biblioteca do Exército, 1974.

SOUSA, Manoel Fernandes. Senador Pompeu: um geógrafo do Império. .....

THEBERGE, Pedro. Esboço Histórico sobre a Província do Ceará. Fortaleza: Fundação Waldemar Alcântara, 2001.

THEOPHILO, Rodolpho. Varíola e Vacinação no Ceará. Fortaleza: Fundação Waldemar Alcântara. (Fac. Sim. de ed. publicada em 1904), 1997. . A Seca de 1915. Fortaleza - ce: Edições UFC, 1980.

História das Secas no Ceará (1877-1879). Rio de Janeiro, Imprensa Inglesa, 1922.

. Libertação do Ceará: queda da oligarquia accioly. Ed. Fac-similar, 1906.

TÁVORA, Franklin. O cabeleira. São Paulo: Três, 1973.

VIEIRA JR, Antonio Otaviano. O Cotidiano do Desvio: Defloramentos e adultérios no Ceará Colonial. Dissertação de mestrado: PUC/SP, 1997.

. Entre Paredes e Bacamartes: História da família no Sertão (1780-1850).

Fortaleza: Edições Demócrito Rocha; Hucitec, 2004. 
KEYNES, Jonh Maynard. Teoria Geral do Emprego, do Juro e do Dinheiro. $2^{\mathrm{a}}$ ed., Rio de Janeiro: Fundo de Cultura S. A., 1970.

KIDDER, Daniel P. Reminiscências de Viagem e Permanências nas Províncias do Norte do Brasil. Trad.: Moacir N. Vasconcelos. São Paulo: Editora da Universidade de São Paulo, 1980.

KUZNESOF, Elizabeth Anne. Household economy and urban development. São Paulo 1765-1836. Boulder: Westview Press, 1986.

VALDÉS, Eduardo Devés. El pensamiento latinoamericano em el siglo XX. Entre la modernización y la identidad, tomo I, Del Ariel de Rodó a la CEPAL (1900-1905). $1^{\mathrm{a}}$ ed. Buenos Aires: Biblos, Centro de Investigaciones Diego Borges Arana, 2000.

ZICMAN, Reneé Barata. História através da Imprensa - algumas considerações metodológicas. Revista Projeto História. № 4. São Paulo, 1981, p.89-120. 